GA-A15940

UC-77

\title{
CAPSULE HRB-15B \\ POSTIRRADIATION EXAMINATION REPORT
}

by

J. W. KETTERER and R. E. BULLOCK

Prepared under

Contract DE-AT03-76ET35300

for the San Francisco Operations Office

Department of Energy

DATE PUBLISHED: JUNE 1981

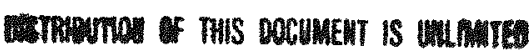

\section{GENERAL ATOMIC COMPANY}


This report was prepared as an account of work sponsored by an agency of the United States Government. Neither the United States Government nor any agency thereof, nor any of their employees, makes any warranty, express or implied, or assumes any legal liability or responsibility for the accuracy, completeness, or usefulness of any information, apparatus, product, or process disclosed, or represents that its use would not infringe privately owned rights. Reference herein to any specific commercial product, process, or service by trade name, trademark, manufacturer, or otherwise, does not necessarily constitute or imply its endorsement, recommendation, or favoring by the United States Government or any agency thereof. The views and opinions of authors expressed herein do not necessarily state or reflect those of the United States Covernment or any agency thereof.

Printed in the United States of America

Available from

National Technical Information Service

U.S. Department of Commerce

5285 Port Royal Road

Springfie1d, VA 22161

NTIS Price Codes: Printed Copy A08; Microfiche A01 


\section{DISCLAIMER}

This report was prepared as an account of work sponsored by an agency of the United States Government. Neither the United States Government nor any agency Thereof, nor any of their employees, makes any warranty, express or implied, or assumes any legal liability or responsibility for the accuracy, completeness, or usefulness of any information, apparatus, product, or process disclosed, or represents that its use would not infringe privately owned rights. Reference herein to any specific commercial product, process, or service by trade name, trademark, manufacturer, or otherwise does not necessarily constitute or imply its endorsement, recommendation, or favoring by the United States Government or any agency thereof. The views and opinions of authors expressed herein do not necessarily state or reflect those of the United States Government or any agency thereof. 


\section{DISCLAIMER}

Portions of this document may be illegible in electronic image products. Images are produced from the best available original document. 
GA-A15940

UC-77

\title{
CAPSULE HRB-15B POSTIRRADIATION EXAMINATION REPORT
}

\author{
by \\ J. W. KETTERER and R. E. BULLOCK
}

Prepared under

Contract DE-AT03-76ET35300 for the San Francisco Operations Office Department of Energy

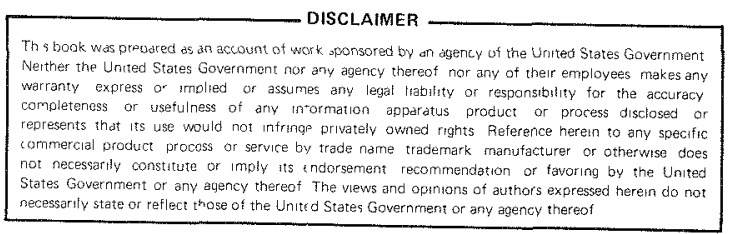

GENERAL ATOMIC PROJECT 6400 DATE PUBLISHED: JUNE 1981

\section{GENERAL ATOMIC COMPANY}


-

- 
ABSTRACT

In a cooperative experiment between General Atomic (GA) and Oak Ridge National Laboratory (ORNL), capsule HRB-15B was successfully irradiated in the ORNL High Flux Isotope Reactor (HFIR) from July 1978 to January 1979. This new HRB capsule design tested 184 thin graphite trays containing unbonded fuel particles manufactured by both GA and ORNL to peak exposures of $6.6 \times 10^{25} \mathrm{n} / \mathrm{m}^{2}$ ( $\mathrm{E}>29 \mathrm{fJ}$ ) HTGR fast fluence, $-27 \%$ fissions per initial metal atom (FIMA) fissile burnup, and 6\% FIMA fertile burnup at nominal time-averaged temperatures of $815^{\circ}$ to $915^{\circ} \mathrm{C}$.

The capsule tested a variety of low-enriched uranium ( $19.5 \% \mathrm{U}-235)$ fissile particle types, including $\mathrm{UC}_{2}, \mathrm{UC}_{\mathrm{X}} \mathrm{O}_{\mathrm{y}}, \mathrm{UO}_{2}$, zirconium-buffered $\mathrm{UO}_{2}$ (referred to in this report as $\mathrm{UO}_{2}^{*}$ ), and $1: 1(\mathrm{Th}, \mathrm{U}) \mathrm{O}_{2}$ with both TRISO and silicon-BISO coatings. All fertile particles were $\mathrm{ThO}_{2}$ with $\mathrm{BISO}$, siliconBISO, or TRISO coatirs. TRISO-coated inert particles were irradiated in piggyback cavities within the capsule.

This report describes the extensive postirradiation examination of the GA fuel samples in $\mathrm{HRB}-15 \mathrm{~B}$. The findings indicate that al1 TRISO particles retained virtually all of their fission product inventories, except small quantities of silver, at these irradiation temperatures, while some of the silicon-BISO particles released significant amounts of both silver and cesium. No kernel migration, pressure vessel, or outer pyrolytic carbon (OPyC) failures were observed in the fuel particles, which had total diameters of $<900 \mu \mathrm{m}$; however, the incidence of failed OPyC coatings was found to increase with particle size in the TRISO inert particles, which had diameters of 1000 to $1300 \mu \mathrm{m}$.

UO 2 particles exhibited no detrimental irradiation effects, but they contained pure carbon precipitates in the kernels after irradiation which were not observed in the undoped $\mathrm{UO}_{2}$ particles. 
Postirradiation examination revealed no differences in the irradiation performance of three $\mathrm{UC}_{\mathrm{x}} \mathrm{O}_{\mathrm{y}}$ kernel types with varying oxygen/uranium ratios. 


\section{CONTENTS}

ABSTRACT . . . . . . . . . . . . . . . . . . . . . .

1. INTRODUCTION . . . . . . . . . . . . . . . . . . . 1-1

2. DESCRIPTION OF EXPERIMENT .................. . . . 2-1

2.1. Test Objectives............... . . . 2-1

2.2. Capsule Design . . . . . . . . . . . . . . 2-1

2.3. Fuel and Piggyback Specimens ........... . 2-3

2.3.1. Fissile Particle Batches . . . . . . . . 2-3

2.3.2. Fertile Particle Batches ......... . 2-4

2.3.3. Inert Particle Piggyback Samples . . . . . . 2-4

3. CAPSUle operation . . . . . . . . . . . . . . . . . . 3-1

4. THERMAL ANALYSIS AND FUEL BURNUP DETERMINATIONS..$\cdot$. . . . 4-1

4.1. Thermal Analysis ....... . . . . . . . 4-1

4.2. Fuel Burnup Determinations .......... . . 4-4

5. POSTIRRADIATION EXAMINATIONS . . . . . . . . . . . . 5-1

5.1. Capsule Removal and Disassembly . . . . . . . . . 5-1

5.2. Visual Exam Details . . . . . . . . . . . 5-3

5.3. Dimensional Change of Graphite Particle Disks . . . . . 5-3

5.4. Particle Tray Autoradiography . . . . . . . . . 5-4

5.5. Metallography ................ 5-6

5.5.1. TRISO-Coated $\mathrm{UC}_{2}, \mathrm{UC}_{\mathrm{X}} \mathrm{O}_{\mathrm{y}},(\mathrm{Th}, \mathrm{U}) \mathrm{O}_{2}$, and $\mathrm{ThO}_{2}$
Particle Types ................ 5-7

5.5.2. $\mathrm{UO}_{2}$ and UO $\mathrm{UR}_{2}^{*} \mathrm{TRO}$ Plus Silicon-Alloyed BISO
Particle Types . . . . . . . . . 5-9

5.6. Electron Microprobe . . . . . . . . . . . 5-11

5.7. Gamma Analysis .. . . . . . . . . . . 5-12

5.7.1. Irradiated Microsphere Gamma Analysis . . . . 5-12

5.7.2. Gamma Scan of Empty Particle Trays . . . . . 5-12

5.8. Postirradiation Gas Analysis .......... . . 5-13

5.9. Fission Gas Release . . . . . . . . . . . . 5-14

5-10. OPyC Coating Densities . . . . . . . . . 5-15 


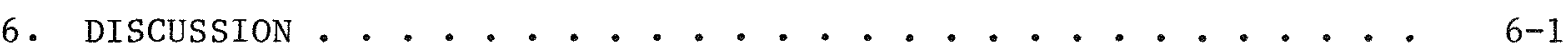

6.1. Retention of the Volatile Metals Cesium and Silver . . . 6-1

6.2. Fissile TRISO Particle Performance . . . . . . . 6-4

6.3. Silicon BISO-Coated Particle Performance . . . . . . 6-5

6.4. $\mathrm{UC}_{\mathrm{x}} \mathrm{O}_{\mathrm{y}}$ Kernels with Different O/U Ratios . . . . . . . 6-7

6.5. POCO Graphite Dimensional Change . . . . . . . . 6-7

6.6. Size Effect on Inert TRISO Particles . . . . . . . . 6-9

6.7. Density-Separated TRISO-Particle Batches . . . . . . 6-10

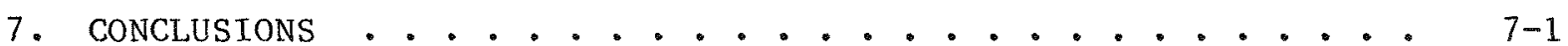

8. REFERENCES . . . . . . . . . . . . . . . 8-1

9. ACKNOWLEDGMENTS . . . . . . . . . . . . . . 9-1

APPENDIX A: FUEL SAMPLE EXPOSURE LEVELS IN HRB-15B..$\cdots$ • • . . A-1

APPENDIX B: UNCERTAINTY ANALYSIS ON REPORTED FUEL PARTICLE

APPENDIX C: GAMMA ANALYSIS AT ORNL . . . . . . . . . . C C-1

APPENDIX D: UNCERTAINTY ANALYSIS ON TRAY GAMMA-SCAN RESULTS $\bullet \cdot . \cdot$ D-1

\section{FIGURES}

2-1. HRB-15B particle tray detail and dimensions . . . . . . . 2-6

2-2. Capsule HRB-15B subassembly details . . . . . . . . . 2-7

2-3. Capsule HRB-15B joint GA/ORNL irradiation test . . . . . 2-8

2-4. Preirradiation $x$-radiograph of $H R B-15 B$, after encapsulation . . . . . . . . . . . . . . 2-9

2-5. Preirradiation photomicrographs of TRISO-coated $\mathrm{UC}_{0} \cdot 2^{0} \mathrm{O}_{1.64}$ particles (6157-09-010) ................ 2-11

2-6. Preirradiation photomicrographs of TRISO-coated UO particles (6152-03-010) ............... 2-12

2-7. Preirradiation photomicrographs of silicon-BISO-coated $\mathrm{UC}_{0.490} 1.12$ particles $(6648-01-010) . . . . . . . . .2-13$

2-8. Preirradiation photomicrographs of silicon-BISO-coated $\mathrm{UC}_{2}$ particles (6449-00-010) ............ 2-14

2-9. Preirradiation photomicrographs of TRISO-coated $\mathrm{ThO}_{2}$ particles (6252-15-010) ................ 2-15

2-10. Preirradiation photomicrographs of silicon-BISO-coated $\mathrm{ThO}_{2}$ particles $(6542-42-010)$.......... 2-16 


\section{FIGURES (Continued)}

2-11. Preirradiation photomicrographs of BISO-coated $\mathrm{ThO}_{2}$ particles (6542-27-015) ............... 2-17

2-12. Preirradiation photomicrographs of TRISO-coated inert particles . . . . . . . . . . . ..... 2-18

4-1. Capsule HRB-15B subassembly 1 graphite tray temperature history .. . . . . . . . . . . . . 4-6

4-2. Capsule $H R B-15 B$ subassembly 2 graphite tray temperature history ................. . . 4-7

4-3. Capsule HRB-15B subassembly 3 graphite tray temperature history .. . . . . . . . . . . . . 4 4-8

4-4. Capsule HRB-15B subassembly 4 graphite tray temperature history ....................... . 4-9

5-1. Gamma-scan of HRB-15B following removal from HFIR . . . . . 5-17

5-2. Subassembly 3 after removal from the containment and application of the reference paint stripe . . . . . . . 5-19

5-3. Special tools used to remotely disassemble the HRB-15B subassemblies .............. . . . 5-20

5-4. Graphite tray No. 84 with irradiated TRISO UC $0.2^{0}{ }_{1.6}$ particles in place ............. 5-21

5-5. Postirradiation appearance of TRISO $\mathrm{UC}_{0.2}{ }^{0} 1.6$ particles from graphite tray No. 84 . . . . . . . . . . . . .

5-6. Graphite tray No. 93 with irradiated TRISO $\mathrm{ThO}_{2}$ particles in

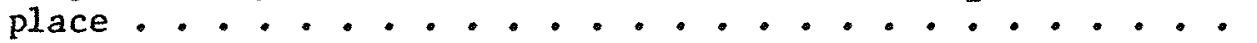

5-7. Postirradiation appearance of TRISO $\mathrm{ThO}_{2}$ particles from graphite tray No. 93 . . . . . . . . . . . . . .

5-8. Postirradiation appearance of silicon-BISO ( $T h, U) \mathrm{O}_{2}$ particles

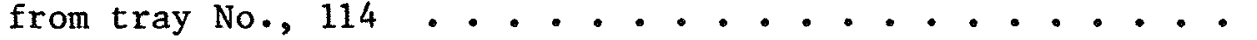

5-9. Postirradiation appearance of silicon-BISO $\mathrm{UO}_{2}$ particles from tray No. 118 . . . . . . . . . . . . . 5-26

5-10. POCO graphite dimensional change in Capsule HRB-15B . . . . 5-27

5-11. Autoradiographs of graphite particle trays, holders

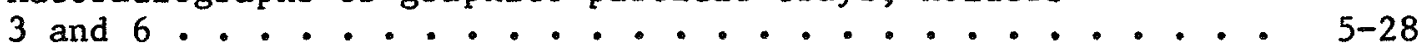

5-12. Autoradiographs of graphite partcle trays, holders

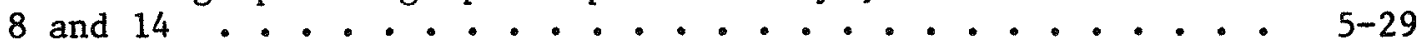

5-13. Postirradiation appearance of TRISO Th0 2 kernels . . . . . 5-30

5-14. Postirradiation appearance of $1: 1(\mathrm{Th}, \mathrm{U}) \mathrm{O}_{2}$ TRISO kernels 
FIGURES (Continued)

5-15. Postirradiation appearance of $\mathrm{UC}_{2}$ TRISO kernels . . . . . 5-32

5-16. Postirradiation appearance of $\mathrm{UC}_{0.70_{0}} .5$ TRISO kernels . . . 5-33

5-17. Postirradiation appearance of $\mathrm{UC}_{0.55^{0}} 1.1$ TRISO kernels . . . 5-34

5-18. Postirradiation appearance of $\mathrm{UC}_{0.2} 2_{1}{ }_{1.6}$ TRISO kernels . . . 5-35

5-19. Examples of kernel extrusion into buffer cracks/voids . . . 5-36

5-20. Postirradiation appearance of TRISO particle from tray No. 168 without the kernel, showing densified buffer caused by fission recoils . . . . . . . . . . 5-37

5-21. Examples of TRISO coating cracks believed to be an artifact of mount preparation ............ . . 5-38

5-22. Examples of short, lenticular flaws observed in unbonded particles irradiated in HRB-15B . . . . . . . . . . 5-39

5-23. SiC porosity type observed in $H R B-15 B$ particles on only the inner half of the SiC layer . . . . . . . . . . 5-40

5-24. SiC porosity type observed both in irradiated $\mathrm{HRB}-15 \mathrm{~B} \mathrm{UC}_{\mathrm{x}} \mathrm{O}_{\mathrm{y}}$ particles and in unirradiated particles from the same batches................ . . . 5-41

5-25. Postirradiation appearance of a UO ${ }_{2}^{*}$ TRISO particle with a solid layer of $\mathrm{ZrC}$ around the kernel . . . . . . . . 5-42

5-26. Postirradiation appearance of a UO ${ }_{2}^{*}$ TRISO particle with $\mathrm{ZrC}$ dispersed throughout the buffer layer ........ . 5-43

5-27. Electron microprobe photos to determine the chemical composition of growth features ......... . . 5-44

5-28. Examples of buffer cracking in UO ${ }_{2}^{*}$ particles . . . . . . 5-45

5-29. An ungettered $\mathrm{UO}_{2}$ TRISO particle following irradiation . . 5-46

5-30. Delamination cracking between the IPyC and silicon-alloyed OPYC portions of a Si-BISO-coated $\mathrm{UO}_{2}$ particle ... . . 5-47

5-31. Demarcation lines caused by bands of higher porosity in the silicon-alloyed coating on a UCO Si-BISO particle . . . 5-48

5-32. Irradiation damage to the inner buffer layer in silicon-alloyed UO ${ }_{2}^{*}$ BISO particles ......... 5-49

5-33. E1ectron microprobe photos of a $\mathrm{UC}_{0.22^{0}} 1.6$ TRISO particle ............. . . 5-50

5-34. Electron microprobe photos of a UC2 TRISO particle . •. . 5-51

5-35. Comparison of measured OPyC density change for standard OPyC coatings from HRB-15B TRISO particles versus published data ................ 5-52 
FIGURES (Continued)

5-36. Measured silicon-OPyC density change versus fluence for four $H R B-15 B$ samples and published values for unrestrained silicon-OPyC .............. . . 5-53

6-1. POCO graphite dimensional change versus fast fluence in HRB-15B . . . . . . . . . . . . . . . 6-12

6-2. Outer coating failure versus fluence for two sizes of particles with two different types of coatings . . . . . 6-13

6-3. Outer coating failure as a function of particle size . . . 6-14

6-4. Effect of deposition rate on coating failure . . . . . . 6-15

$A-1$. Fertile burnup versus position in HRB-15B . . . . . . . A

$\mathrm{A}-2$. Fissile burnup versus position in $\mathrm{HRB}-15 \mathrm{~B} . .$. . . . . . . A-4

$\mathrm{A}-3$. Fast fluence versus position in $\mathrm{HRB}-15 \mathrm{~B} . . . . . . . . . \mathrm{A}-5$

TABLES

2-1. General description of GA coated particle batches tested in HRB-15B ................... . 2-19

3-1. Reactor operating history during HRB-15B irradiation . . . 3-3

3-2. Capsule HRB-15B in-pile fission gas release . . . . . . . 3-4

4-1. HRB-15B isotopic ratios and calculated burnup values . . . 4-10

5-1. Failure fractions of GA TRISO-coated inert particles

5-2. Dimensional change of $\mathrm{HRB}-15 \mathrm{~B}$ graphite trays . . . . . . 5-55

5-3. Comparison of GA particle batch visual exam results with
particle tray autoradiographic observations . . . . . . 5-56

5-4. Results of metallographic examination on GA TRISO-coated $\mathrm{ThO}_{2}, 1: 1(\mathrm{Th}, \mathrm{U}) \mathrm{O}_{2}$, and $\mathrm{UC}_{\mathrm{x}} \mathrm{O}_{\mathrm{y}}$ tested in $\mathrm{HRB}-15 \mathrm{~B} . . .$. . 5-57

5-5. GA particle samples tested in $H R B-15 B$ submitted for IMGA analysis at ORNL .............. 5-58

5-6. Comparison of gamma-scan results with autoradiography of HRB-15B graphite trays . . . . . . . . . . 5-59

5-7. PGA results of $11 \mathrm{GA}$ particle batches tested in HRB-15B . . 5-60

5-8. Pre- and postirradiation fission gas release of three GA TRISO-coated particle types tested in HRB-15B . . . . . 5-61

5-9. OPyC density of seven GA particle types tested in

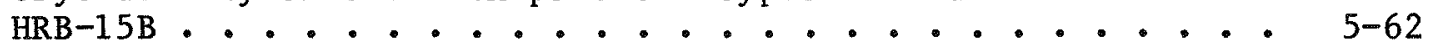


TABLES (Continued)

5-10. Description of GA inert TRISO particles tested in HRB-15B...................... 5-63

5-11. Attribute comparison of density-separated batches with GA parent batches tested in HRB-15B ........... 5-64

6-1. Measured and calculated percent release values for Cs-137 and $\mathrm{Ag}-110 \mathrm{~m}$ from fissile particles irradiated in capsule

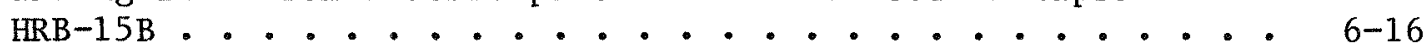

$A-1$. $\quad H R B-15 B$ particle exposure levels for subassembly 1 . . . . A-6

$A-2$. HRB-15B particle exposure levels for subassembly 2 . . . . A-7

A-3. HRB-15B particle exposure levels for subassembly 3 . . . A A-8

A-4. HRB-15B particle exposure levels for subassembly 4 . . . . A-9

B-1. Mean values and estimated standard deviations for each variable in Eq. 4-1 . . . . . . . . . . . . B B-2

$\mathrm{B}-2$. Partial derivatives of $\mathrm{Eq} \cdot 4-1$ and mean value evaluations for use in Eq. B-1 . . . . . . . . . . . . . B B-3

$\mathrm{C}-1$. Summary of $\mathrm{Cs}-137 / \mathrm{Zr}-95, \mathrm{Ag}-110 \mathrm{~m} / \mathrm{Zr}-95, \mathrm{Cs}-137 / \mathrm{Ru}-106$, and $\mathrm{Ag}-110 \mathrm{~m} / \mathrm{Ru}-106$ observed/calculated ratios for HTGR fuel particles irradiated in capsule HRB-15B . . . . . . . C C 7

C-2. Comparison of observed and calculated fission product inventories for fuel particles irradiated in position $\mathrm{HRB}-15 \mathrm{~B}-116 . . . . . . . . . . . . . ~ C-8$

$\mathrm{C}-3$. Comparison of calculated $\mathrm{Cs}-137 / \mathrm{Ru}-106$ and $\mathrm{Ag}-110 \mathrm{~m} / \mathrm{Ru}-106$ ratios using different cross sections . . . . . . . . C-9

C-4. One-group microscopic cross sections used in capsule HRB-15B burnup analysis ................ C-10

$\mathrm{C}-5$. Comparison of calculated $\mathrm{Cs}-137 / \mathrm{Zr}-95$ and $\mathrm{Ag}-110 \mathrm{~m} / \mathrm{Zr}-95$ ratios using different cross sections . . . . . . . . . C-11

$\mathrm{C}-6$. Comparison of fission yields between fissile isotopes . . . $\mathrm{C}-12$ 


\section{INTRODUCTION}

The development of acceptable fuel types for the high temperature gascooled reactor (HTGR) has been an on-going effort at General Atomic Company (GA) for more than two decades. Two commercial-size HTGRs, the Peach Bottom and Fort St. Vrain nuclear generating stations, have demonstrated the feasibility of the coated-particle fuel concept in real-time exposure conditions. Complementing these data have been an extensive array of accelerated irradiation tests which have provided evaluation, qualification, and proof-testing of numerous particle and fuel material types. This work has qualified a fresh fuel system consisting of a high-enriched uranium (HEU) (93\% U-235) $\mathrm{UC}_{2}$ TRISO-coated fissile particle and a BISO-coated $\mathrm{ThO}_{2}$ fertile particle, both supported by an extensive data base.

Nuclear industry requirements are constantly changing, however, necessitating flexibility, the refinement of existing designs, and the continued development of new fuel types. Recent concern in this country, for example, in the proliferation of potentially subvertable fuel materials has led to the need for qualification of low-enriched uranium (LEU) ( $20 \% \mathrm{U}-235)$ fuels. Ever-increasing restrictions and safety considerations also dictate more reliable coatings and particle designs that are acceptable, yet able to be manufactured on a production scale.

Capsule HRB-15B was one of several irradiation tests that specifically addressed these current areas of HTGR fuel particle development. A variety of LEU fissile types, particle coating designs, and advanced fuel types were tested to exposure levels representative of generic lead plant conditions. In a cooperative experiment between GA and Oak Ridge National Laboratory (ORNL), capsule HRB-15B irradiated unbonded coated fuel particles, manufactured by both participants, in the ORNL High Flux Isotope Reactor (HFIR) from July 1978 to January 1979. The capsule achieved a peak fast 
fluence of $6.6 \times 10^{25} \mathrm{n} / \mathrm{m}^{2}$ (E > $29 \mathrm{fJ}$ )HTGR with nominal fuel particle temperatures from $815^{\circ}$ to $915^{\circ} \mathrm{C}$. The capsule was dismantled after the irradiation, and the fuel samples were examined and characterized in detail. This report discusses the postirradiation examination (PIE) findings on the GA fuel particles tested. 


\section{DESCRIPTION OF EXPERIMENT}

\subsection{TEST OBJECTIVES}

Capsule HRB-15B had the following primary objectives:

1. Characterize the irradiation performance of several LEU fissile fuel particle types subjected to exposure levels typical of reference lead plant conditions.

2. Provide irradiated fuel particles for out-of-pile postirradiation heating tests.

3. Evaluate the effect of variations in the oxygen/uranium $(\mathrm{O} / \mathrm{U})$ ratio on the performance of dense UCO.

4. Provide in-pile verification of the pressure vesse1 performance models with LEU fuel.

5. Provide an initial test of $\mathrm{UO}_{2}$ particles with $\mathrm{ZrC}$ dopant as an oxygen getter (referred to in this report as $\mathrm{UO}_{2}^{*}$ ).

6. Investigate possible advantages in fission product retention with silicon-alloyed outer pyrolytic carbon (OPyC) layers on BISO-coated particles of all kernel types tested.

\subsection{CAPSULE DESIGN}

Capsule $H R B-15 B$ differed in design from previous $H R B$ experiments in that it did not test fuel rods, but only unbonded particle fuel samples. Since a large variety of fuel particle types were to be tested at varying 
exposure levels, the design had to offer separability of many capsule samples. Accordingly, $H R B-15 B$ tested fuel particles in 184 thin graphite planchets or trays. Figure 2-1 details the dimensions and fuel particle hole pattern drilled into the trays.* The holes in the trays were patterned and spaced for fuel particle heat transfer, tray structural integrity throughout irradiation, and a maximum number of fuel particles in the experiment.

Although the trays were not always completely filled, each could accommodate up to 116 fuel particles, one per hole.

To facilitate loading and handling of the fuel samples, the trays were grouped into four subassemblies of 46 particle trays each. Each subassembly consisted of a central graphite spine onto which the particle trays were stacked on top of each other, as shown in Fig. 2-2. A spacer at the midplane and two end disks, secured with stainless steel screws, held the assemblies securely together. Stainless steel pins pressed into the circumferences of the mid-spacers, and end disks centered the subassemblies in the primary containment tube. In addition to the primary capsule fuel particles, the cavities had piggyback space machined in the graphite subassembly spines.

The four HRB-15B subassemblies were installed in a double containment, as shown in Fig. 2-3, with subassembly 1 at the top of the stack. This arrangement placed particle tray No. 1 at the top of the experiment with trays numbered consecutively down through tray No. 184 at the bottom. Thermocouples and a gas line were routed into the experiment in grooves machined into the outer surface of the subassembly center spines. Eight chrome1alumel thermocouples monitored temperatures at two locations in each subassembly throughout the irradiation. The primary containment sweep gas was a mixture of helium and neon at a nominal flow rate of $0.3 \mathrm{ml} / \mathrm{s}$, while the $\mathrm{sec}-$ ondary containment was statically pressurized with pure helium. Adjustments in the primary gas mixture allowed reactor personnel to control capsule temperatures during the irradiation.

*A11 figures and tables are grouped at the end of each section. 
No flux dosimeters were included in this capsule, since the removable beryllium ( $R B$ ) section of the HFIR has been adequately characterized for neutron flux in numerous irradiation tests.

\subsection{FUEL AND PIGGYBACK SPECIMENS}

Capsule HRB-15B included fuel particles from 47 different particle batches. Eighteen of these were fabricated and tested by ORNL; the remaining $29 \mathrm{GA}$ batches consisted of 23 fissile and fertile and six inert particle batches. This report will not discuss the ORNL fuel samples, consisting of $\mathrm{BISO}-$ and TRISO-coated $\mathrm{ThO}_{2}$ particles; they will be covered in future ORNL documents. The $23 \mathrm{GA}$ fissile and fertile fuel particle batches included UCO, $\mathrm{UO}_{2}$ (with and without $\mathrm{ZrC}$ getter), $\mathrm{UC}_{2}$, $(\mathrm{Th}, \mathrm{U}) \mathrm{O}_{2}$, and $\mathrm{ThO}_{2}$ particles with TRISO and silicon-BISO coatings and $\mathrm{ThO}_{2}$ particles with BISO coatings. Table $2-1$ is a general description of all GA fuel particle batches tested in HRB-15B. Reference 1 futher details batch attributes.

The fuel particles were irradiated in graphite trays, one particle per hole, and were not mixed (i.e., each tray contained only one particle type). The trays were arranged in an alternating fissile-fertile sequence over the entire capsule length for temperature uniformity throughout the test. Figure $2-4$ is a radiograph of the loaded subassemblies after encapsulation in the containment tubes. Figure 2-4 clearly shows the particles in the graphite trays, the thermocouples, and the subassembly components.

\subsubsection{Fissile Particle Batches}

GA fabricated al1 fissile particle types tested in HRB-15B using the so1-gel process and 35-mm laboratory coaters. The variety of fissile kernels tested fulfilled the major experimental objective to compare several LEU kernel types to help select the reference LEU fissile fuel in the near future. The fissile candidates are $\mathrm{UC}_{2}, \mathrm{UO}_{2}^{*}$, and $\mathrm{UC}_{\mathrm{x}} \mathrm{O}_{\mathrm{y}}$. Four UCO kernels were tested [ low oxygen $\left(\mathrm{UC}_{0} .69^{\circ} 0.51\right.$ and $\left.\mathrm{UC}_{0.71^{\circ}} \mathrm{O}_{0.54}\right)$, medium oxygen 
$\left(\mathrm{UC}_{0.490_{1}} .12\right)$, and high oxygen $\left(\mathrm{UC}_{0} .20^{\circ} 1.64\right)$ ] to study the effect of $\mathrm{O} / \mathrm{U}$ ratio variations on irradiation performance. The test included a standard $\mathrm{UO}_{2}$ design and two types of $\mathrm{UO}_{2}^{*}$, one with the $\mathrm{ZrC}$ dispersed throughout the buffer layer and the other with a pure $\mathrm{ZrC}$ coating around the kerne1. The zirconium dopants were included to investigate their effect on kernel migration, one of the drawbacks of the oxide particle types. HRB-15B also tested several batches of ( $\mathrm{Th}, \mathrm{U}) \mathrm{O}_{2}$ and $\mathrm{UC}_{2}$ fissile kernels. Every fissile kernel type was tested in both TRISO-coated and silicon-BISO-coated particles. Silicon-BISO-coated particles were included for kernel migration studies on irradiated particles to be done out-of-pile. Why kernel migration has not been observed in postirradiation heating tests of TRISO particles is not known; however, this lack of migration could be due to gaps between the coating layers. Since the silicon-BISO coating probably would not develop gaps, it represented a more suitable particle type for these tests. Figures 2-5 through 2-8 show representative preirradiation photos of several of the fissile particle types tested. The preirradiation report (Ref.1) gives photographs of all the fissile particle batches.

\subsubsection{Fertile Particle Batches}

$\mathrm{HRB}-15 \mathrm{~B}$ irradiated two production-size $\mathrm{ThO}_{2}$ batches, one TRISO-coated (6252-15-010, 240-cm coater) and one BISO-coated (6542-27-010, 127-mm coater). Two other silicon-BISO-coated (35-mm laboratory coater) $\mathrm{ThO}_{2}$ batches were included to investigate potential performance improvements with this coating type. Figures 2-9 through 2-11 show representative preirradiation photos of TRISO-, BISO-, and silicon-BISO-coated $\mathrm{ThO}_{2}$ particles. Reference 1 gives photographs of all the fertile particle batches tested in $\mathrm{HRB}-15 \mathrm{~B}$.

\subsubsection{Inert Particle Piggyback Samples}

HRB-15B tested inert particles from six different batches in cavities machined in the graphite center spines of each of the four subassemblies. The capsule included $\sim 1000$ particles to test size effects on coating 
strength and possible OPyC strength increases with silicon dopants. Three batches (6351-05-010, -020, and -030) had a nominal 1000-um substrate, and the other three (6351-050-040, -050, and -060) had a 1arger 1200- $\mu \mathrm{m}$ substrate. Two batches (6351-05-010 and -040) had regular OPyC coatings, while the other four had OPyC coatings doped with silicon. All six inert particle batches were TRISO coated; Fig. 2-12 shows preirradiation photos of one large and one small inert particle type tested. Reference 1 gives preirradiation photos of all inert particle types tested in the capsule. 

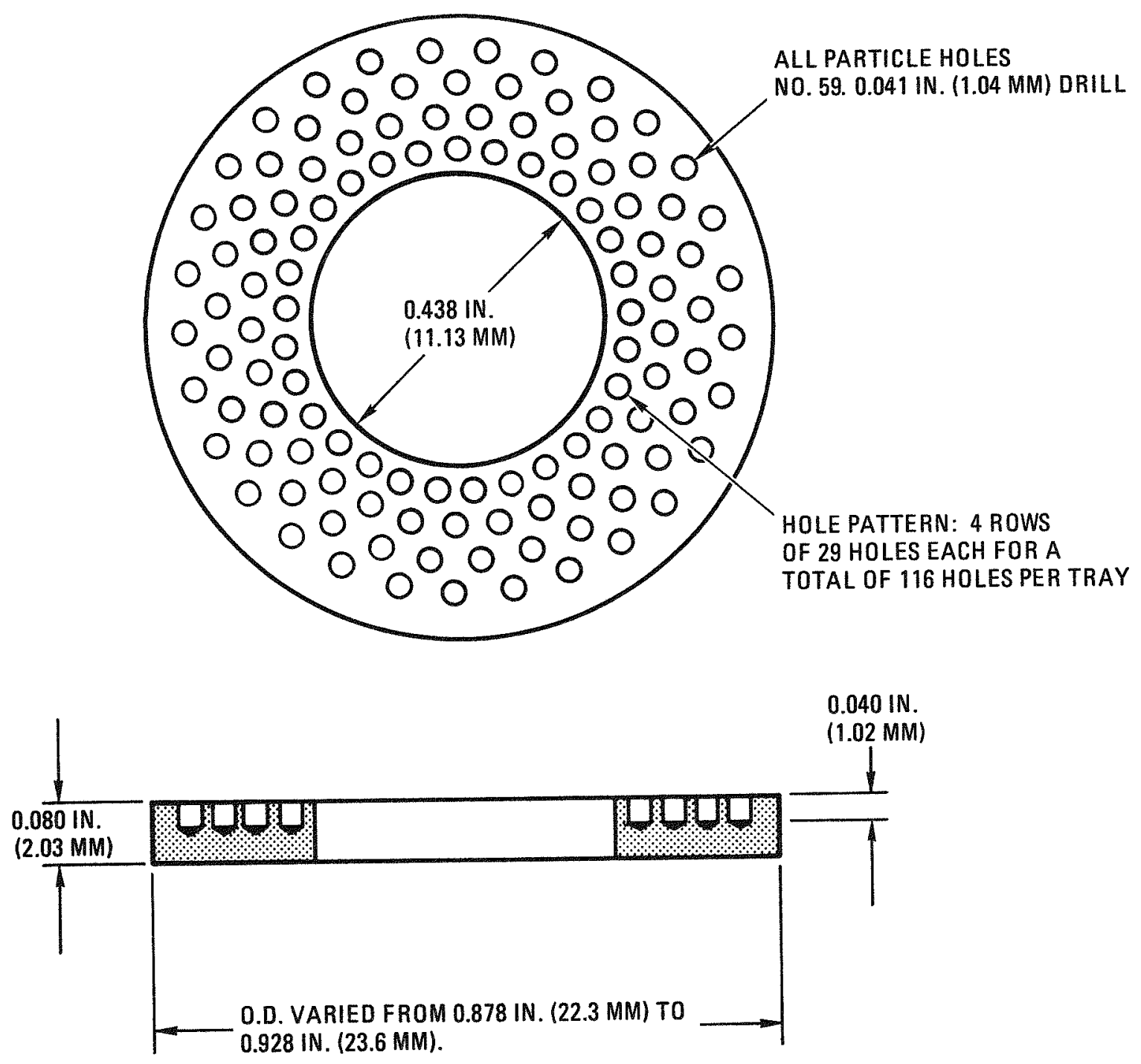

Fig. 2-1. HRB-15B particle tray detail and dimensions 


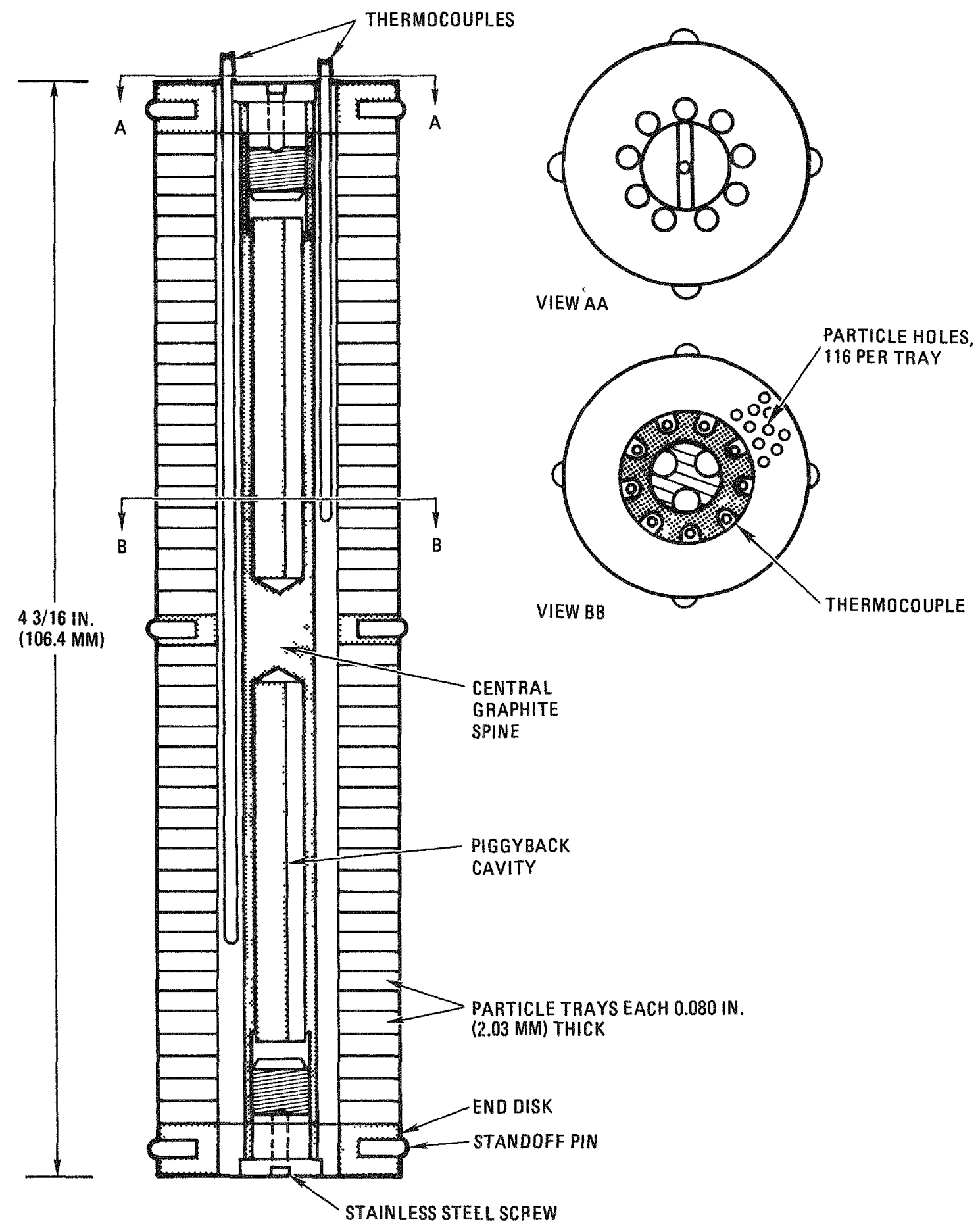

Fig. 2-2. Capsule HRB-15B subassembly details 


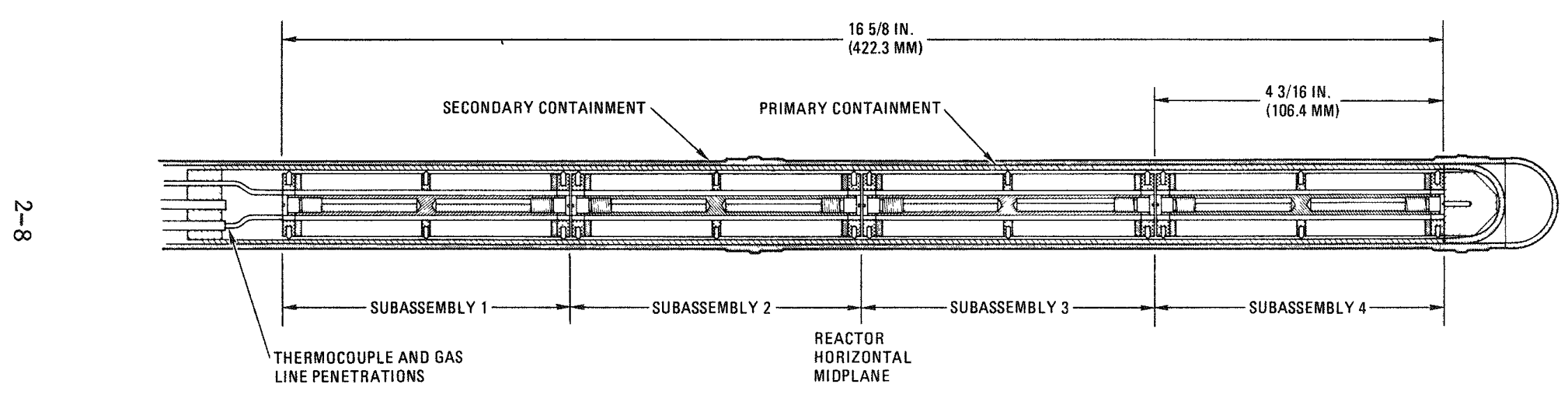

Fig. 2-3. Capsule HRB-15B joint GA/ORNL irradiation test 


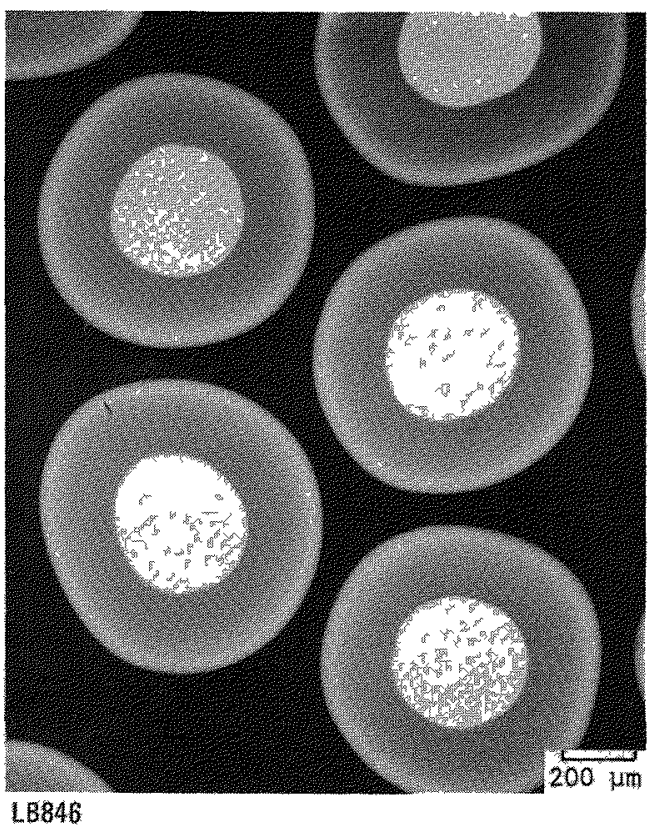

(a)

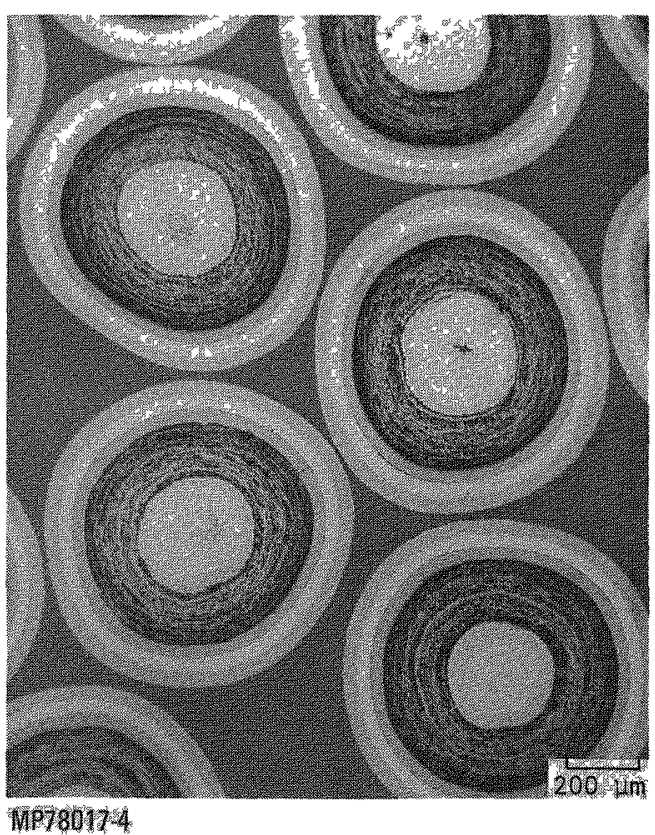

(ces

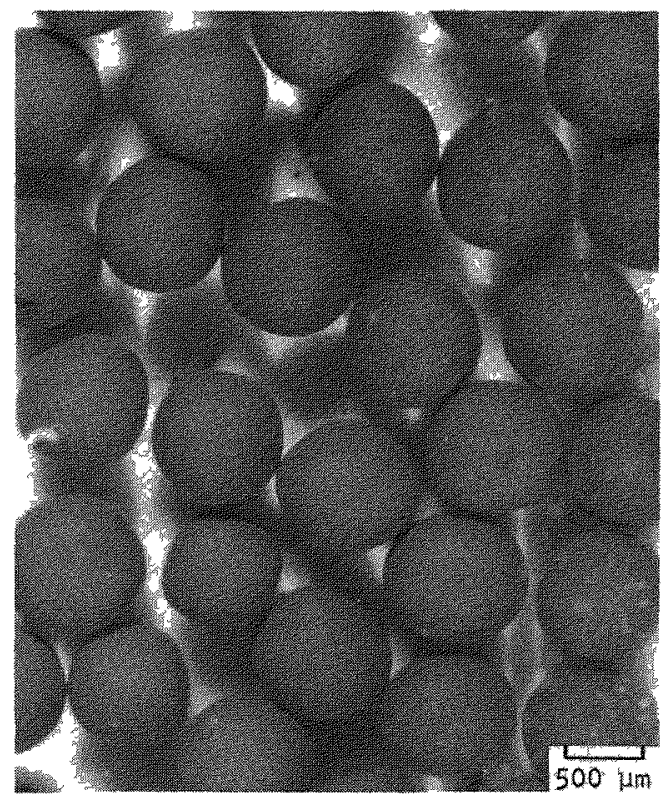

SP780211

(b)

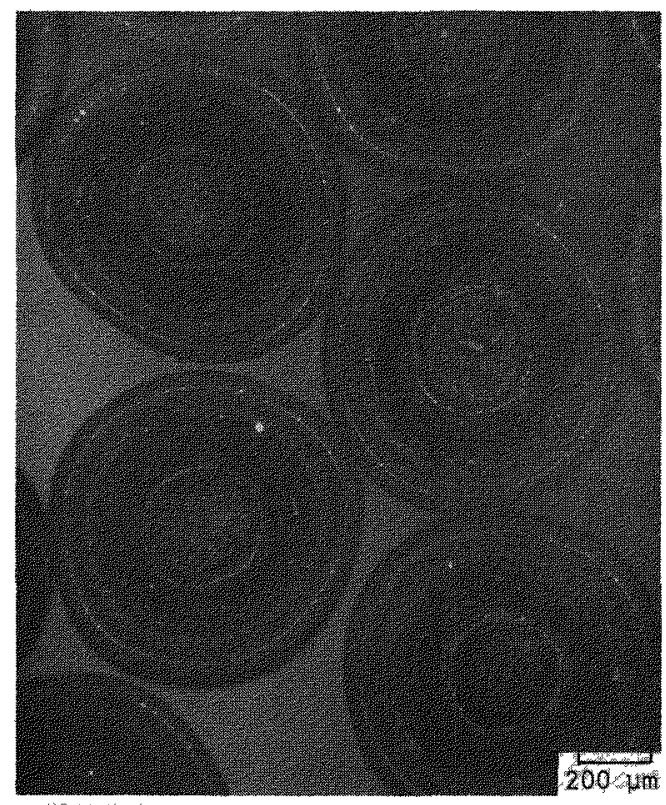

(4)

Fig. 2-5. Preirradiation photomicrographs of TRISO-coated $\mathrm{UC}_{0.2} \mathrm{O}_{1} .64$ particles (6157-09-010): (a) radiograph, (b) stereo view, (c) bright field, (d) polarized light 


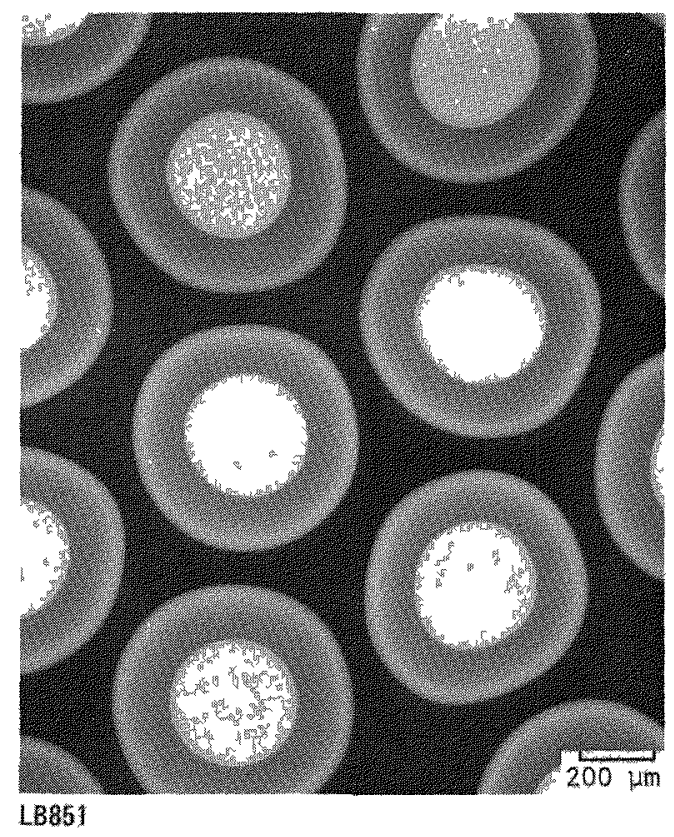

(a)

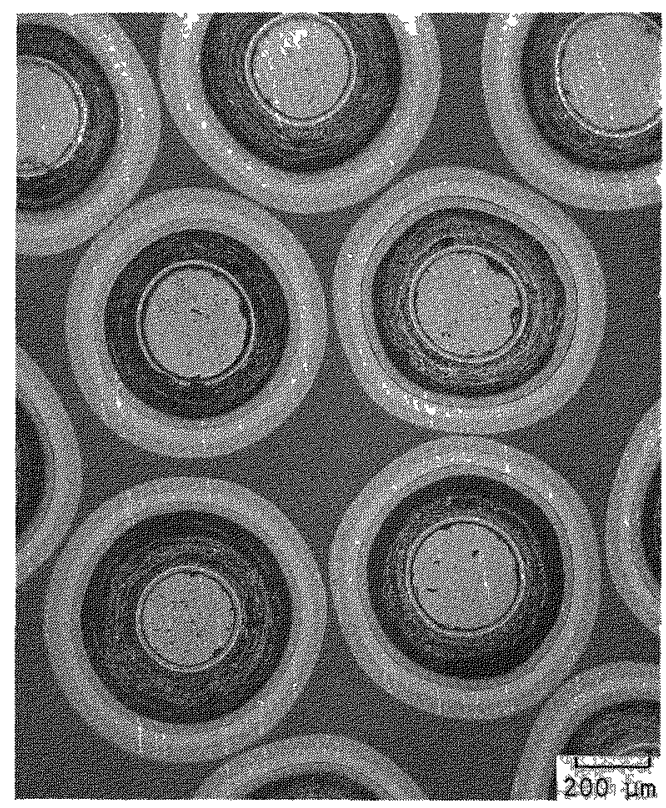

Nptoms-4

(c)

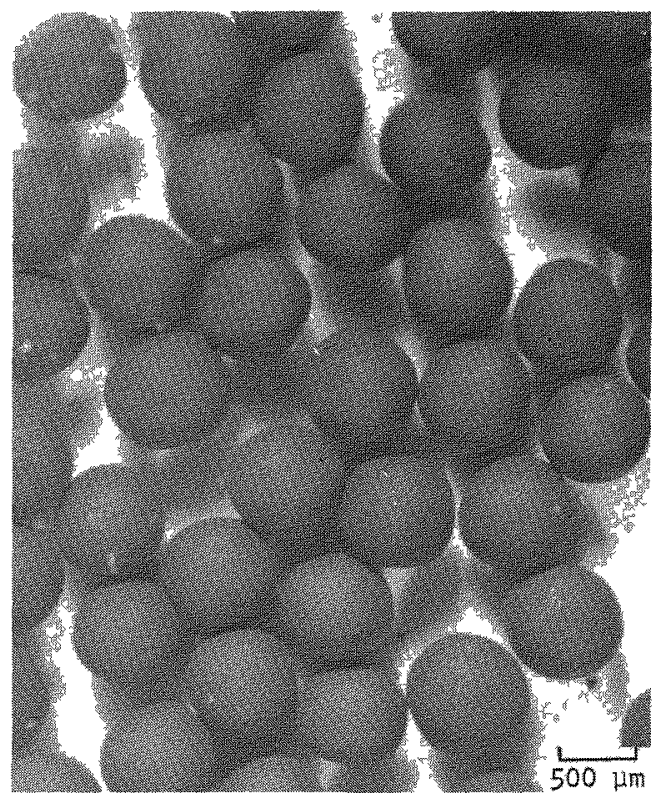

SP78019-1

(b)

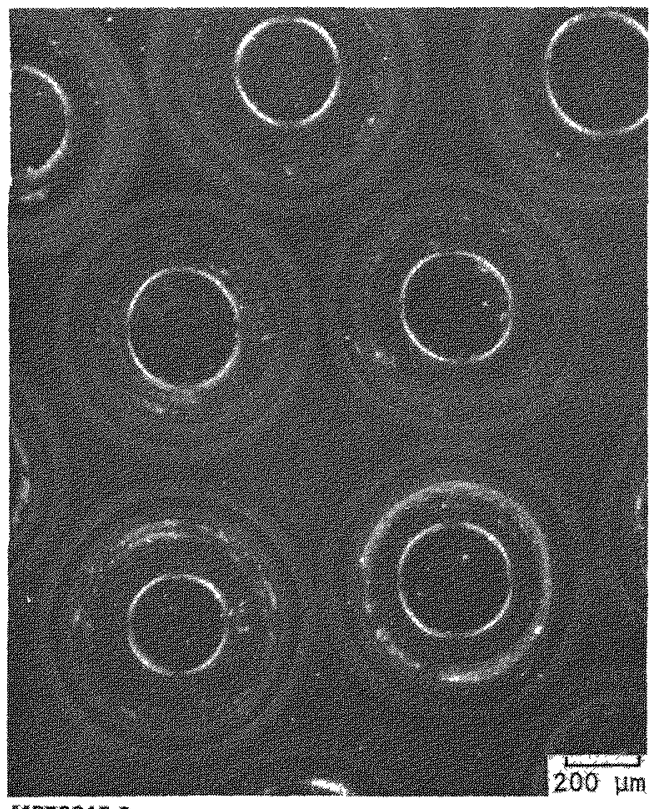

MP78015 2

(d)

Fig. 2-6. Preirradiation photomicrographs of TRISO-coated $\mathrm{UO}_{2}$ * particles (6152-03-010): (a) radiograph, (b) stereo view, (c) bright field, (d) polarized 1ight. This batch had a $\mathrm{ZrC}$ layer applied to the kernel. 


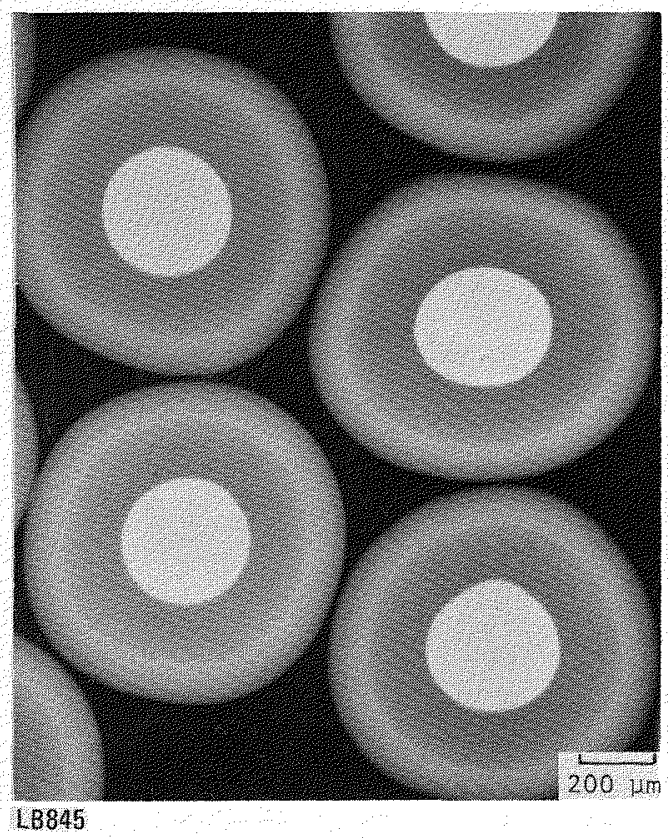

(a)

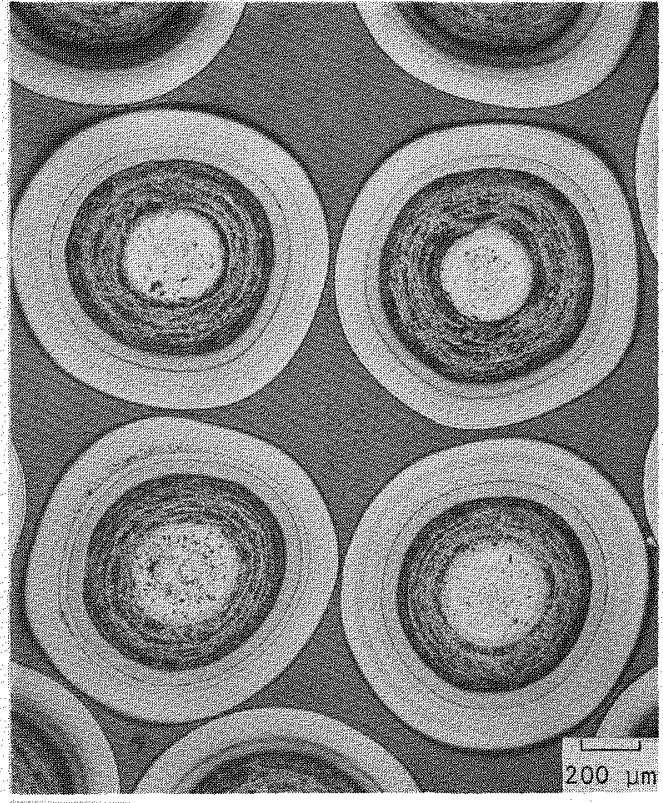

MP78022-1

(c)

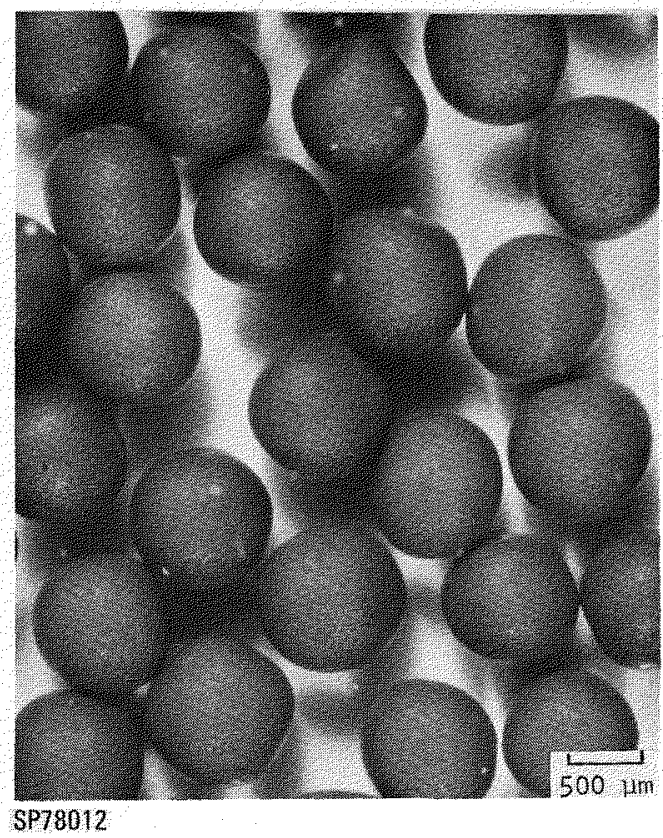

(b)

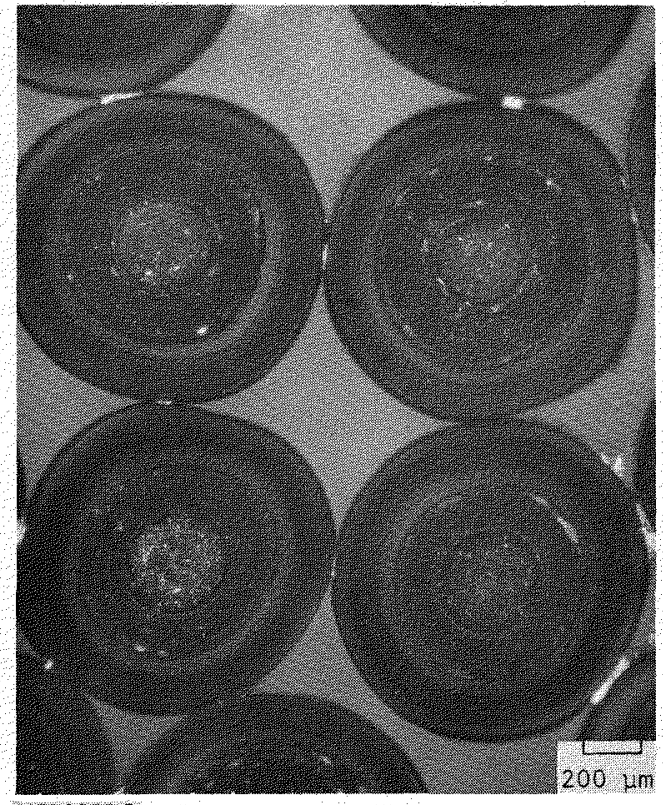

MP78022.2

(d)

Fig. 2-7. Preirradiation photomicrographs of silicon-BISO-coated $\mathrm{UC}_{0.49^{0}} 1.12$ particles (6448-01-010): (a) radiograph, (b) stereo view, (c) bright field, (d) polarized light 


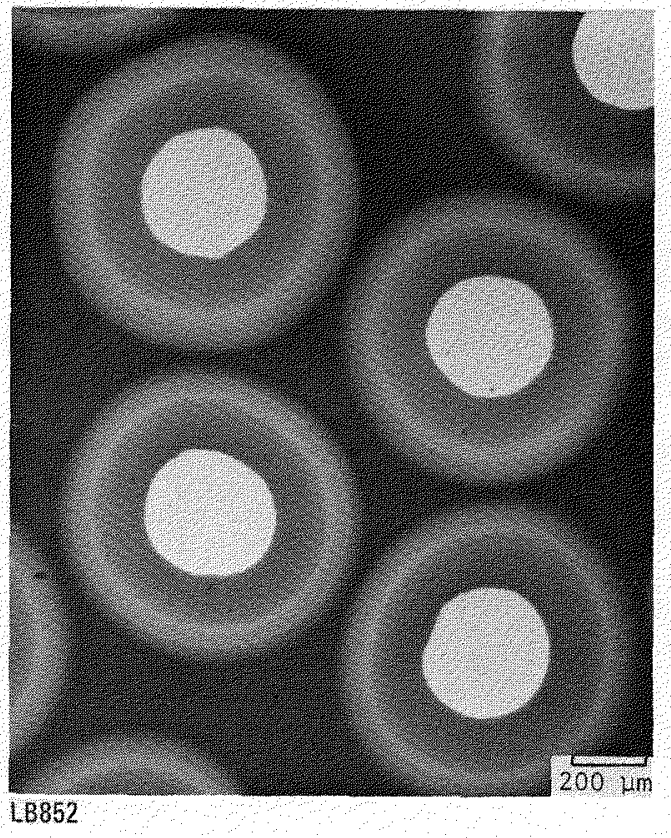

(a)

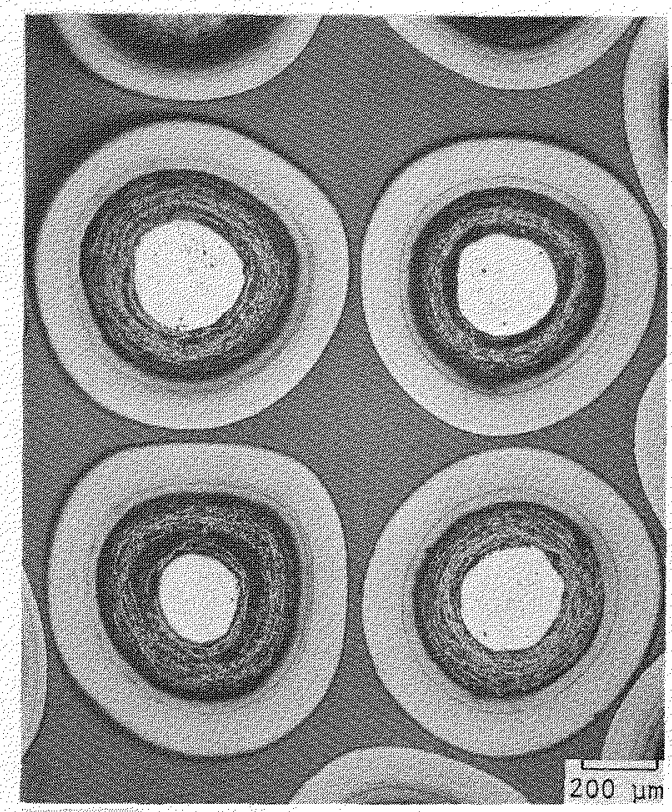

MP780261

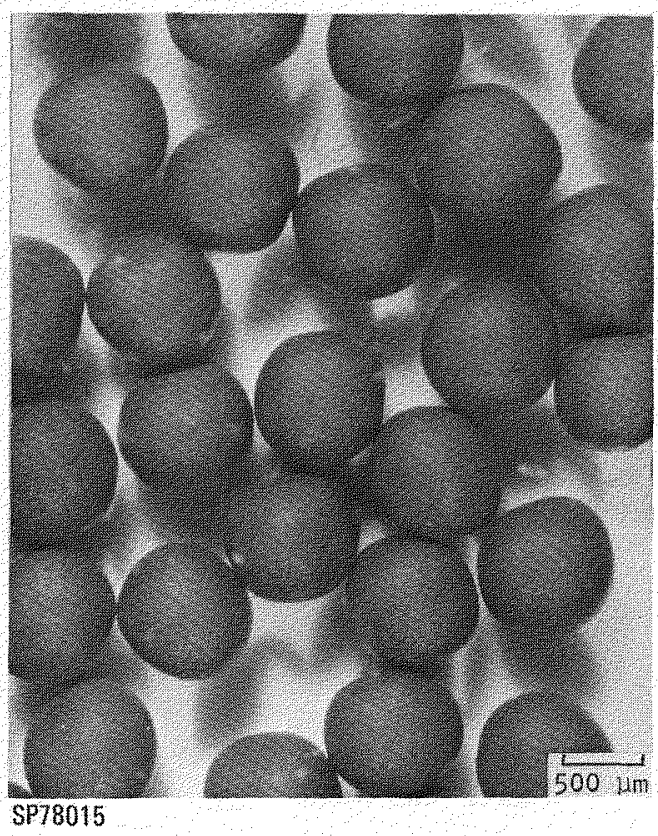

(b)

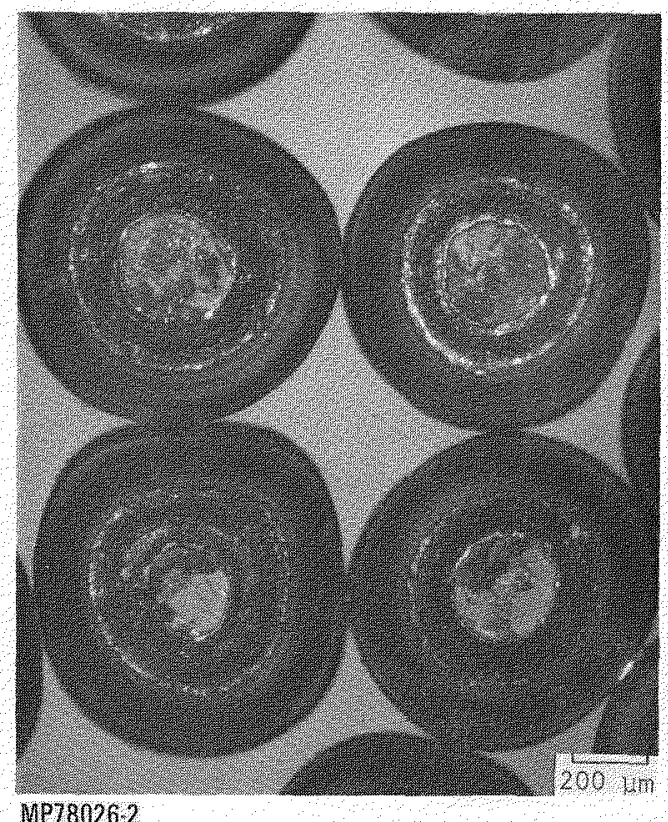

(d)

Fig. 2-8. Preirradiation photomicrographs of silicon-BISO-coated UC 2 particles (6449-00-010): (a) radiograph, (b) stereo view, (c) bright field, (d) polarized light 


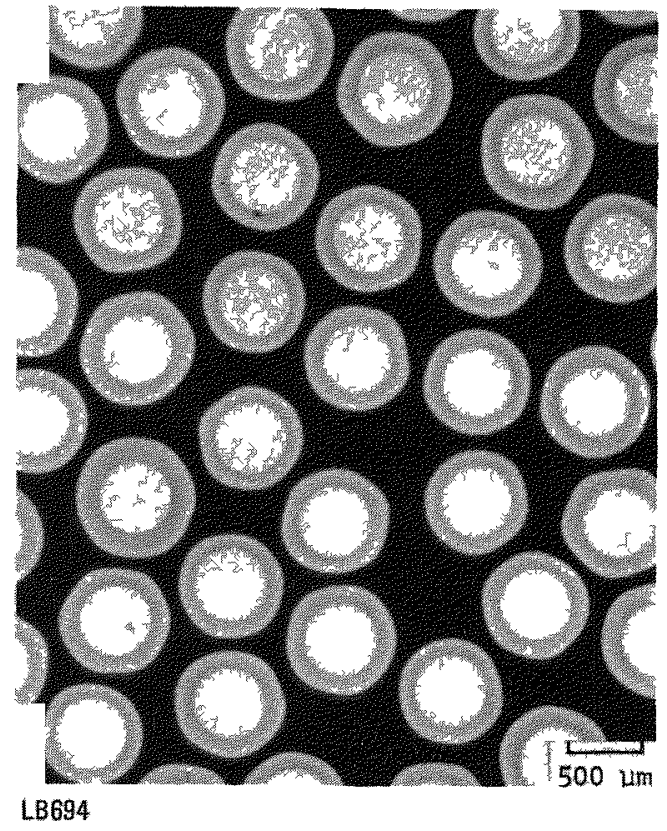

(a)

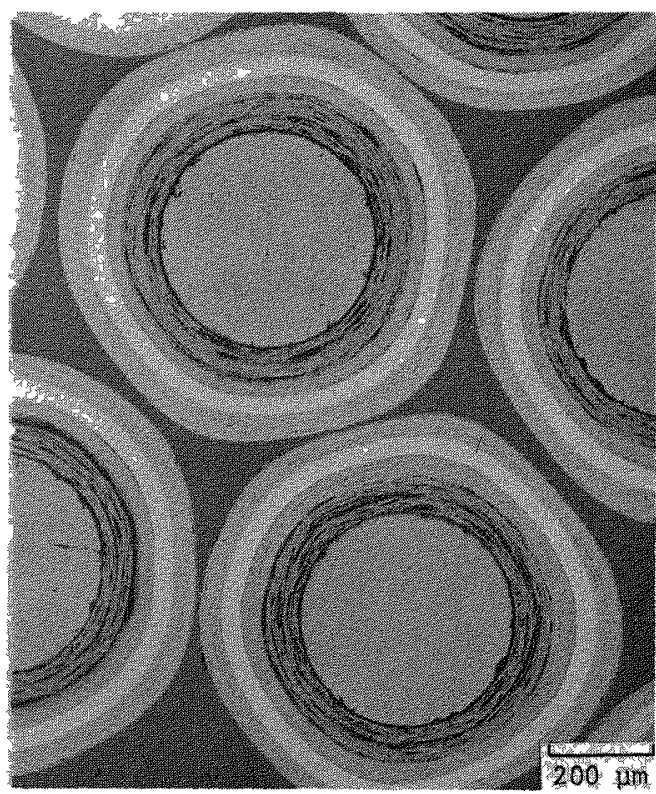

MP77009-4

(c)

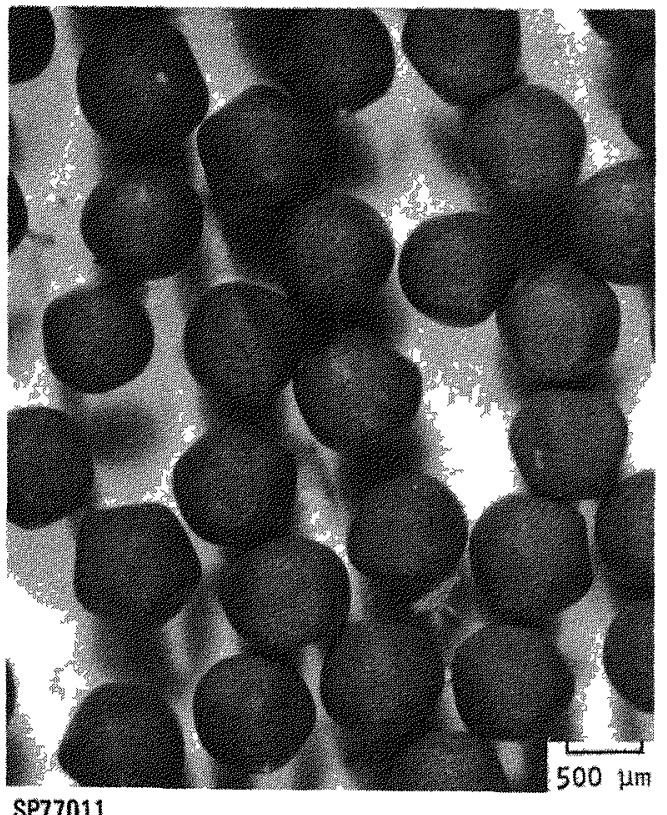

(b)

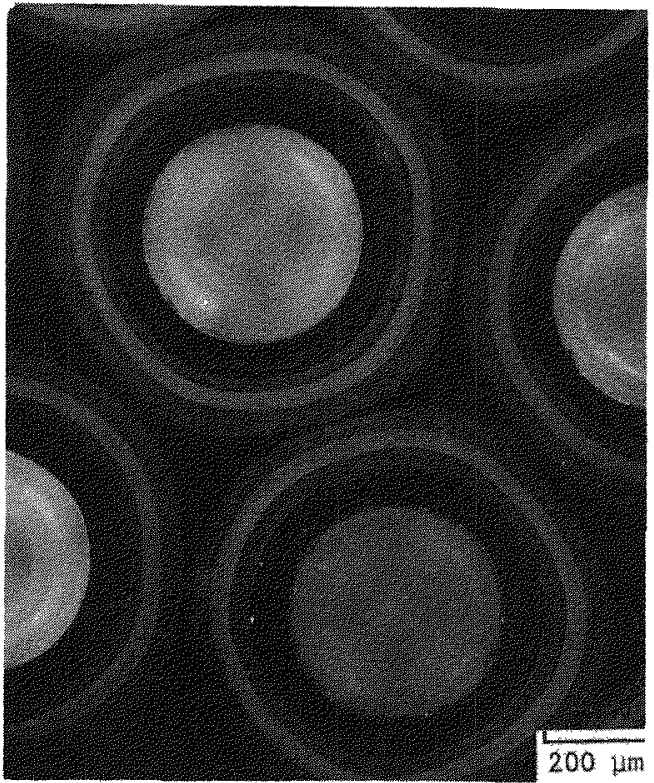

MP77009 6

Fig. 2-9. Preirradiation photomicrographs of TRISO-coated $\mathrm{ThO}_{2}$ particles (6252-15-010): (a) radiograph, (b) stereo view, (c) bright field, (d) polarized light 


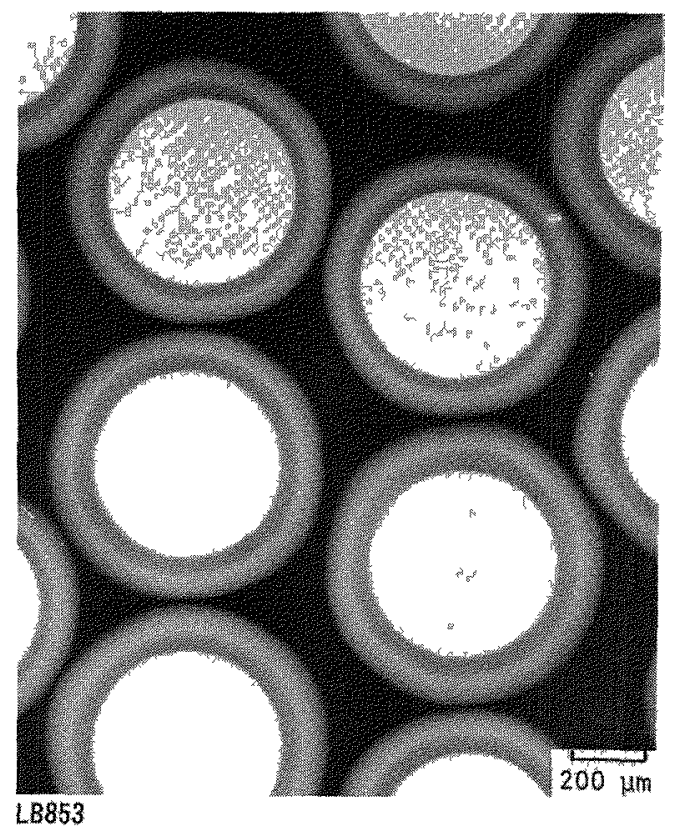

(a)

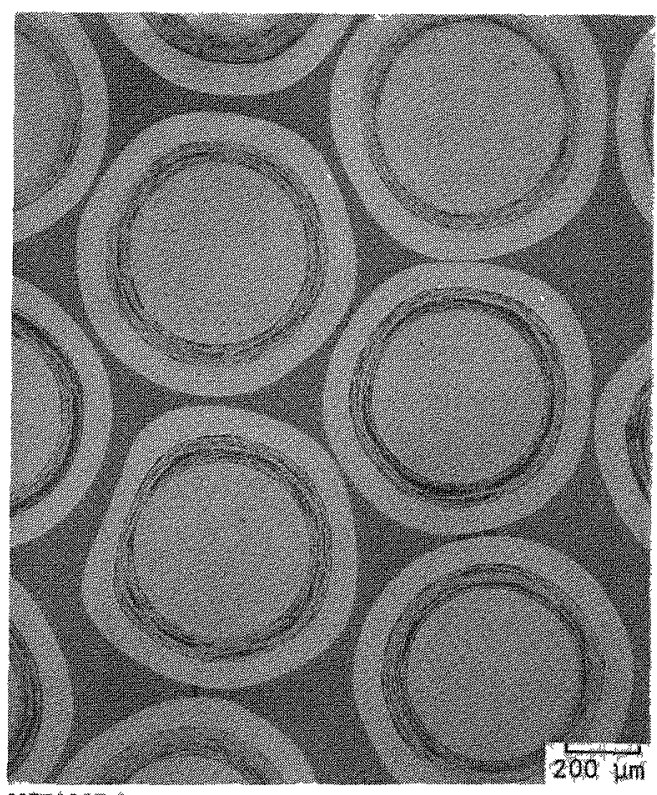

MP78027.1

(c)

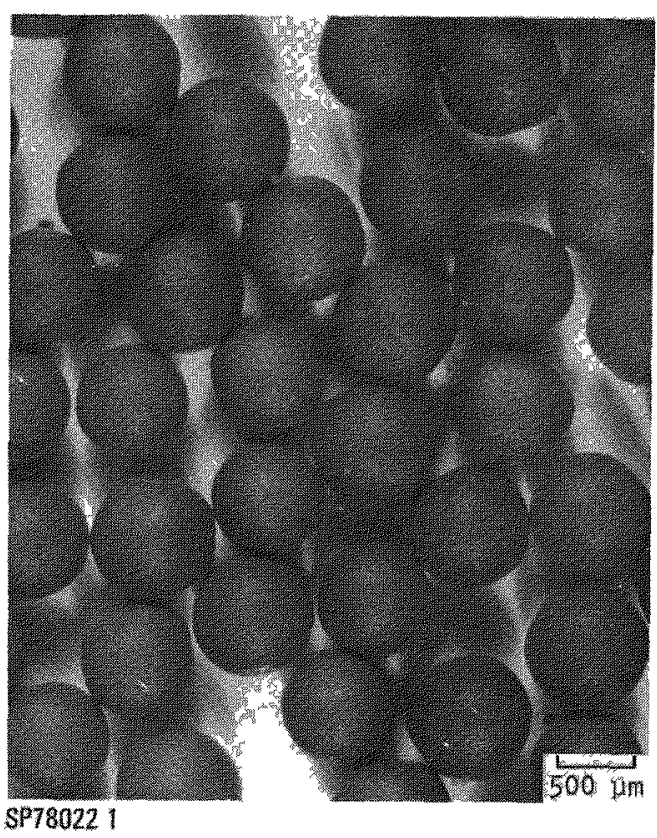

(b)

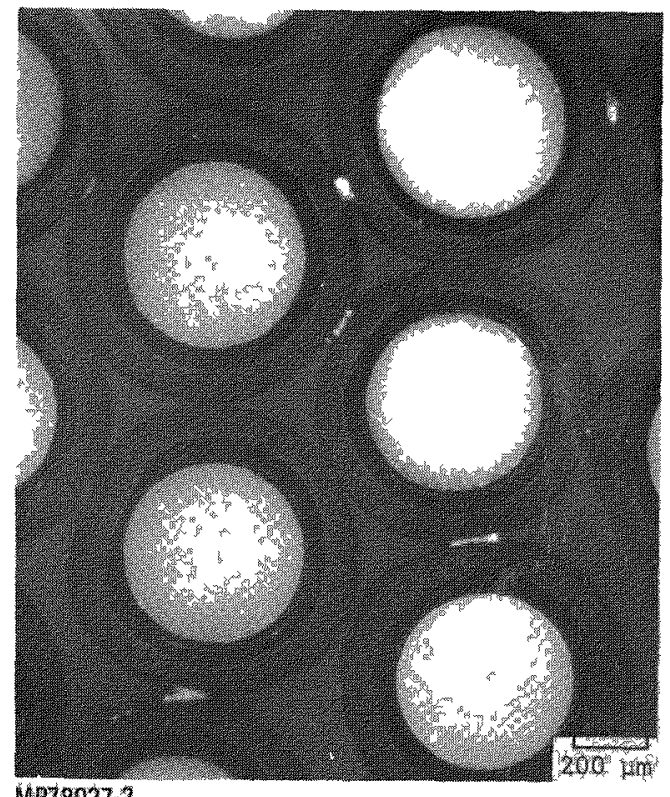

MP78027.2

(d)

Fig. 2-10. Preirradiation photomicrographs of silicon-BISO-coated $\mathrm{ThO}_{2}$ particles (6542-42-010): (a) radiograph, (b) stereo view, (c) bright field, (d) polarized light. 


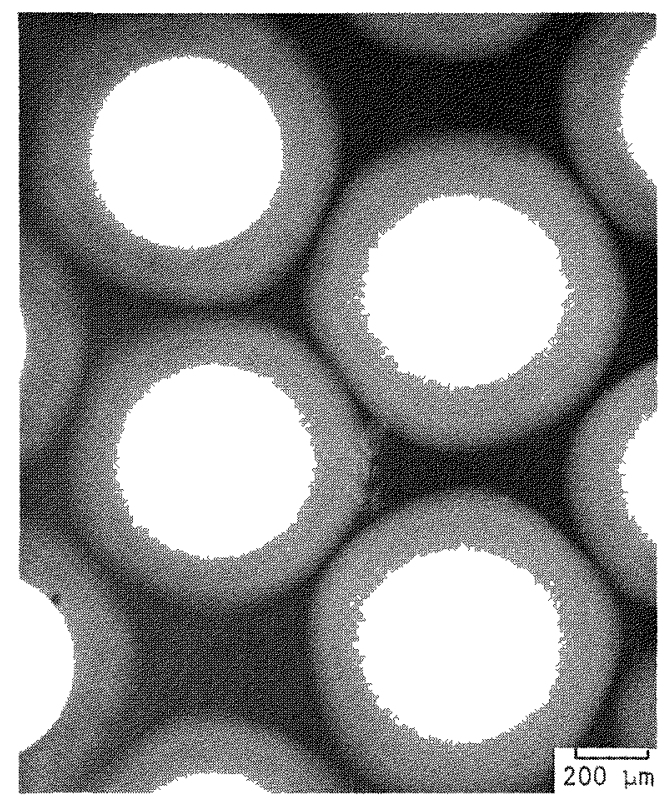

LA109 2

(a)

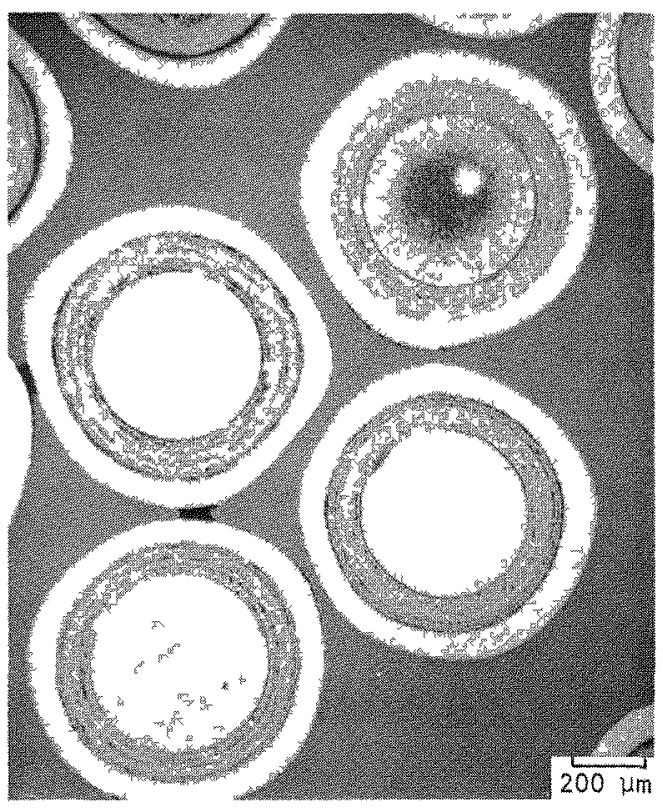

MP74031 2

(c)
NO STEREO VIEW AVAILABLE

FOR THIS PARTICLE BATCH

(b)

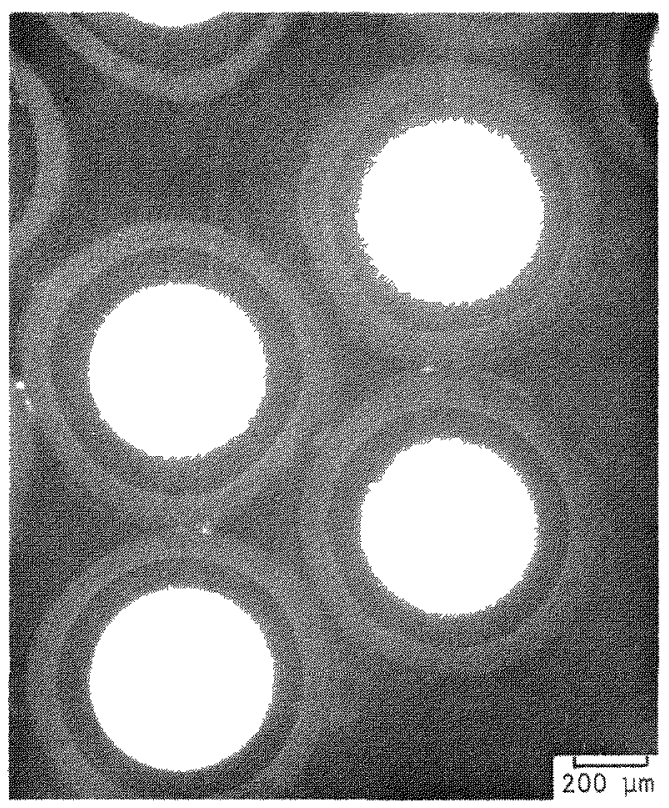

MP74031-1

(d)

Fig. 2-11. Preirradiation photomicrographs of BISO-coated $\mathrm{ThO}_{2}$ particles (6542-27-015): (a) radiograph, (b) stereo view, (c) bright field, (d) polarized light 


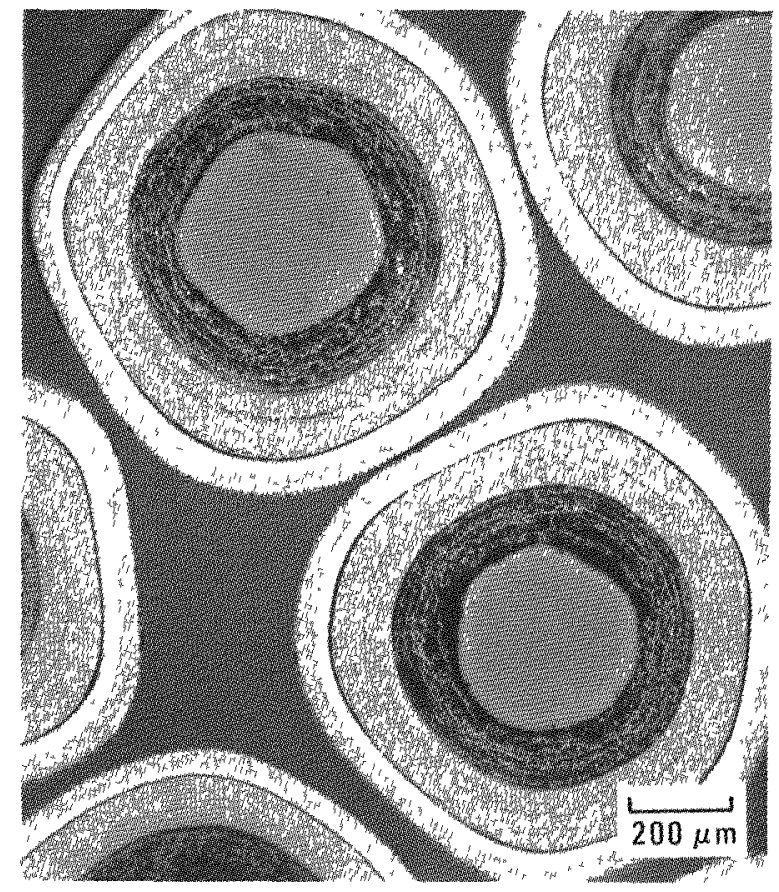

MP77030-6

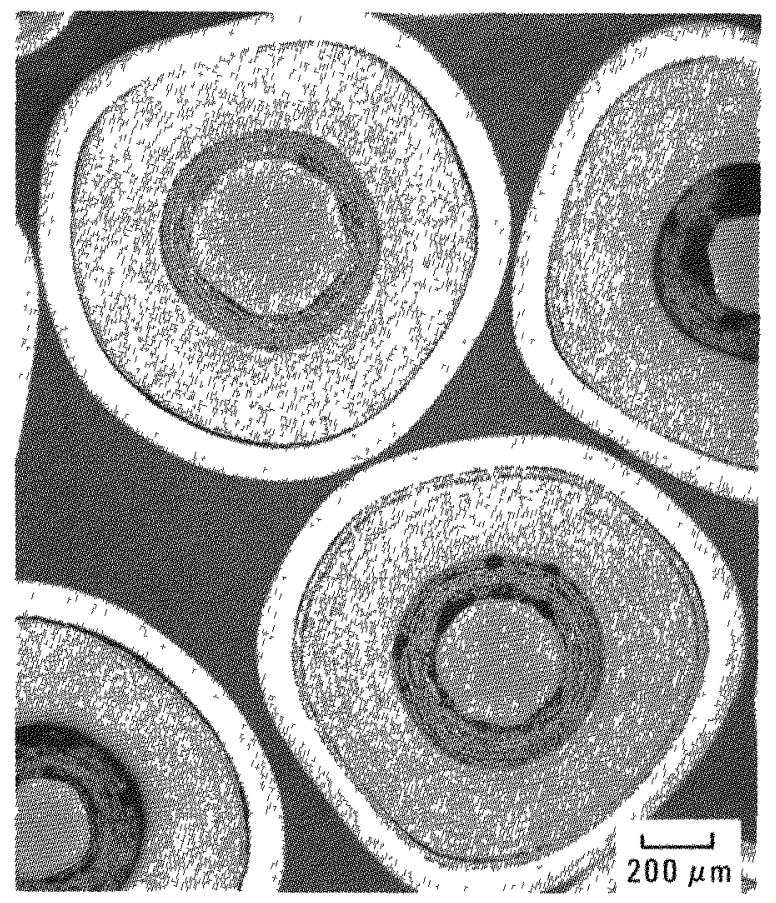

MP78033-1 (a)

(c)

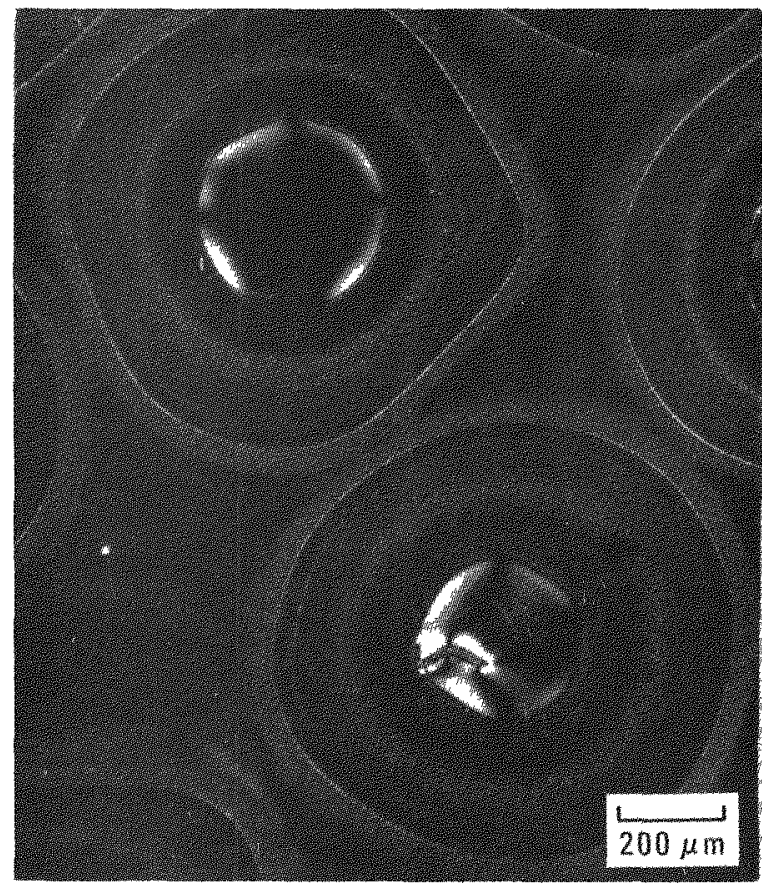

(b)

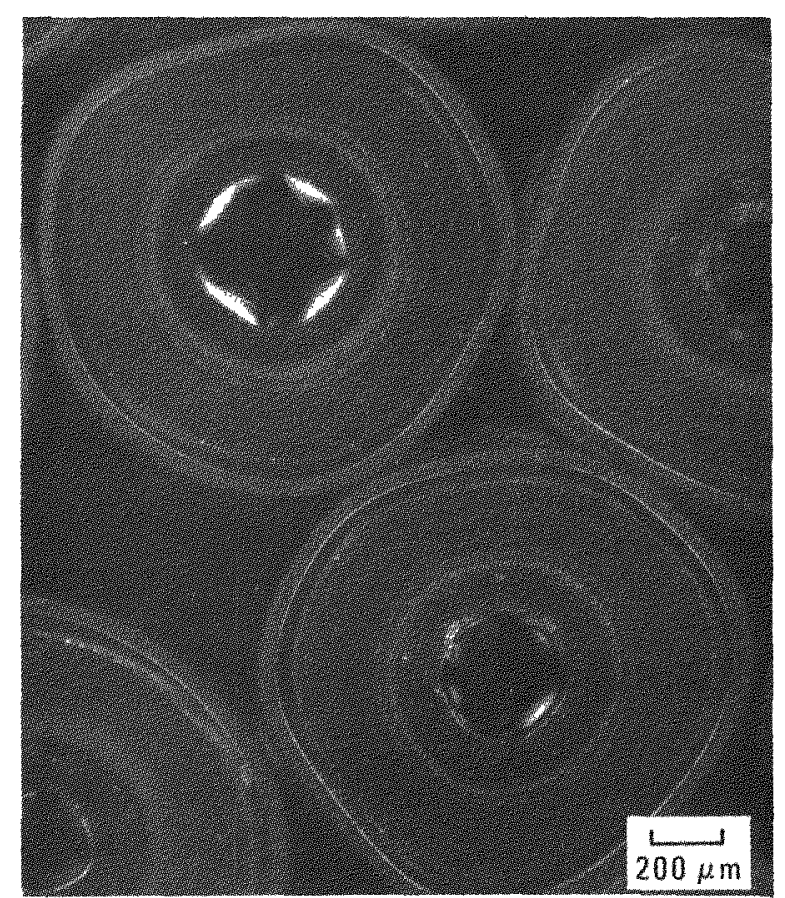

MP78033-2

(d)

Fig. 2-12. Preirradiation photomicrographs of TRISO-coated inert particles: (a) (6351-05-010) bright field, (b) (6351-05-010) polarized light, (c) (6351-05-040) bright field, and (d) (6351-05-040) polarized light 


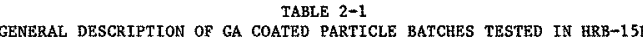

\begin{tabular}{|c|c|c|c|c|c|c|c|c|c|c|c|c|c|c|c|c|c|c|c|c|c|c|}
\hline \multirow[b]{3}{*}{$\begin{array}{c}\text { FMB } \\
\text { Parent } \\
\text { Batch No. }\end{array}$} & \multirow[b]{3}{*}{$\begin{array}{c}\text { Coating }^{(b)} \\
\text { Type }\end{array}$} & \multicolumn{2}{|c|}{ Rerne1 } & \multicolumn{3}{|c|}{ Buffer } & \multicolumn{3}{|c|}{$\mathrm{IPyC}^{(\mathrm{a})}$} & \multicolumn{2}{|c|}{ Sic } & \multicolumn{3}{|c|}{$\mathrm{OPyC}$} & \multicolumn{8}{|c|}{ Total coated Particle } \\
\hline & & \multirow[b]{2}{*}{ Type } & \multirow[b]{2}{*}{$\begin{array}{l}\text { Diam } \\
\text { ( Im) }\end{array}$} & \multirow[b]{2}{*}{$\begin{array}{c}\text { Thick- } \\
\text { ness } \\
\text { (um) }\end{array}$} & \multirow[b]{2}{*}{$\mid \begin{array}{l}\text { Density } \\
\left.\left(\mathrm{Ms}_{\mathrm{g}} / \mathrm{m}^{3}\right)^{3}\right)\end{array}$} & \multirow[b]{2}{*}{$\begin{array}{l}\text { Seal } \\
\text { Coat }\end{array}$} & \multirow[b]{2}{*}{\begin{tabular}{|l} 
Thick- \\
ness \\
( $\mu \mathrm{m})$
\end{tabular}} & \multirow[b]{2}{*}{$\begin{array}{l}\text { Densitity } \\
\left(\mathrm{Mg} / \mathrm{m}^{3}\right)\end{array}$} & \multirow[b]{2}{*}{$\mathrm{BAF}_{\mathrm{o}}^{(\mathrm{c})}$} & \multirow[b]{2}{*}{$\begin{array}{c}\text { Thick- } \\
\text { ness } \\
(\text { um })\end{array}$} & \multirow[b]{2}{*}{$\begin{array}{l}\text { Density } \\
\left(\mathrm{Mg} / \mathrm{m}^{3}\right)\end{array}$} & \multirow[b]{2}{*}{ 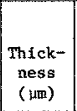 } & \multirow[b]{2}{*}{\begin{tabular}{|} 
Densit ty \\
$\left(M g / \mathrm{m}^{3}\right)$
\end{tabular}} & \multirow[b]{2}{*}{$B A F_{0}^{(c)}$} & \multirow[b]{2}{*}{ 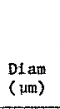 } & $\left|\begin{array}{c}\text { Total } \\
\text { coating }\end{array}\right|$ & & & & sion, & Exposed He & avy Meta1 \\
\hline & & & & & & & & & & & & & & & & \begin{tabular}{|l} 
Thick- \\
ness \\
$(\mu \mathrm{min})$
\end{tabular} & $\begin{array}{c}\text { Hg } \\
\text { Denst thy } \\
\left(\mathrm{Mg} / \mathrm{tr}^{3}\right)\end{array}$ & $\begin{array}{l}\text { Metal to } \\
U \\
\text { (wt \%) }\end{array}$ & $\begin{array}{l}\text { Thing } \\
\text { (wt \%) }\end{array}$ & $\begin{array}{c}\text { Relesase (d) } \\
\text { (R/B) }\end{array}$ & $\begin{array}{c}\text { UranIum } \\
(\mathrm{g} U / \mathrm{g} \\
\text { heavy meta1) }\end{array}$ & \begin{tabular}{|c|} 
Thorium \\
(g v/g \\
heavy meta1)
\end{tabular} \\
\hline $6155-05-010$ & TRISO & $(\mathrm{Th}, \mathrm{U}) \mathrm{O}_{2}$ & 357 & 94 & 1.09 & None & 34 & 1.87 & 1.046 & 36 & 3.21 & 46 & 1.87 & 1.032 & 760 & 202 & 2.83 & 17.05 & 16.42 & $8.0 \times 10^{-7}$ & $7.75 \times 10^{-8}$ & 0 \\
\hline $6155-05-020$ & TRISO & $(\mathrm{Th}, \mathrm{v}) \mathrm{O}_{2}$ & 361 & 117 & 1.09 & None & 32 & 1.89 & 1.051 & 36 & 3.22 & 48 & 1.86 & 1.035 & 813 & 226 & 2.65 & 15.26 & 14.77 & $1.10 \times 10^{-6}$ & $5.00 \times 10^{-8}$ & $1.62 \times 10^{-6}$ \\
\hline $6157-08-020$ & TRISO & $v c_{0.69^{\circ}}{ }_{0.51}$ & 353 & 101 & 1.15 & None & 35 & 1.87 & 1.039 & 40 & 3.21 & 49 & 1.91 & 1.029 & 786 & 215 & 2.76 & 36.86 & $N / A^{(e)}$ & $6.10 \times 10^{-7}$ & $1.10 \times 10^{-6}$ & 0 \\
\hline $61.57-08-030$ & TRISO & $\mathrm{vc}_{0.49^{\circ}}{ }_{1.12}$ & 359 & 123 & 0.98 & None & 47 & 1.84 & 1.030 & 41 & 3.18 & 44 & 1.84 & 1.027 & 863 & 249 & 2.49 & 25.89 & $\mathrm{~N} / \mathrm{A}$ & $9.00 \times 10^{-7}$ & $2.5 \times 10^{-7}$ & $7.13 \times 10^{-7}$ \\
\hline $6157-09-010$ & TRISO & $\mathrm{vc}_{0.20^{\circ}}{ }_{1.64}$ & 372 & 136 & 0.93 & None & 43 & 1.93 & 1.033 & 41 & 3.16 & 42 & 1.85 & 1.029 & 877 & 254 & 2.50 & 26.80 & $\mathrm{~N} / \mathrm{A}$ & $2.00 \times 10^{-7}$ & $2.80 \times 10^{-6}$ & 0 \\
\hline $6152-01-010$ & TRISO & $\mathrm{UO}_{2}$ & 299 & 134 & 1.15 & None & 41 & 1.91 & 1.045 & 32 & 3.21 & 40 & 1.87 & 1.032 & 769 & 235 & 2.37 & 21.36 & $\mathrm{~N} / \mathrm{A}$ & $2.50 \times 10^{-7}$ & $1.30 \times 10^{-3}$ & 0 \\
\hline $6152-02-010$ & TRISO & $\operatorname{vot}_{2}^{(f)}$ & 314 & 98 & 1.22 & Yes & 35 & 1.91 & 1.041 & 38 & 3.19 & 41 & 1.90 & 1.033 & 767 & 225 & 2.62 & 24.51 & $\mathrm{~N} / \mathrm{A}$ & $2.40 \times 10^{-7}$ & $1.00 \times 10^{-6}$ & 0 \\
\hline $6152-03-010$ & TRISO & $\operatorname{vot} \frac{\pi}{2}(g)$ & 312 & 82 & 0.91 & Yes & 35 & 1.92 & 1.036 & 37 & 3.20 & 41 & 1.87 & 1.031 & 742 & 213 & 2.64 & 26.62 & $\mathrm{~N} / \mathrm{A}$ & $1.6 \times 10^{-7}$ & $1.30 \times 10^{-6}$ & 0 \\
\hline $6152-03-020$ & TRISO & $\operatorname{wo}_{2}^{*}(\mathrm{~h})$ & 312 & 93 & 0.87 & yes & 39 & 1.84 & 1.030 & 36 & 3.21 & 40 & 1.82 & 1.026 & 770 & 230 & 2.52 & 24.58 & $\mathrm{~N} / \mathrm{A}$ & $1.1 \times 10^{-6}$ & $3.10 \times 10^{-7}$ & 0 \\
\hline $6151-21-010$ & Iso & $\mathrm{UC}_{2}$ & 348 & 121 & 0.94 & None & 37 & 1.86 & 1.033 & 39 & 3.16 & 50 & 1.82 & 1.030 & 835 & 243 & 2.55 & 28.19 & $\mathrm{~N} / \mathrm{A}$ & $5.0 \times 10^{-7}$ & $7.60 \times 10^{-7}$ & 0 \\
\hline $6252-15-010$ & TRISO & $\mathrm{ThO}_{2}$ & 456 & 54 & 1.07 & None & 36 & 1.85 & 1.060 & 38 & 3.22 & 48 & 1.81 & 1.030 & 807 & 176 & 3.36 & $\mathrm{~N} / \mathrm{A}$ & 45.85 & $4.04 \times 10^{-6}$ & 0 & $4.90 \times 10^{-6}$ \\
\hline $6445-01-010$ & $S I-B I S O$ & $(T h, \mathrm{v}) \mathrm{O}_{2}$ & 359 & 111 & 0.65 & None & 42 & 1.93 & $\mathrm{~N} / \mathrm{A}$ & $N / A$ & $N / A$ & 218 & 2.05 & $\mathrm{w} / \mathrm{A}$ & 905 & 271 & 2.44 & 12.02 & 12.13 & $4.1 \times 10^{-7}$ & $8.21 \times 10^{-7}$ & $4.50 \times 10^{-5}$ \\
\hline $6448-02-010$ & SI-BISO & $v c_{0.71} 0_{0.54}$ & 343 & 117 & 1.20 & None & 37 & 1.88 & $\mathrm{~N} / \mathrm{A}$ & $\mathrm{N} / \mathrm{A}$ & N/A & 121 & 2.09 & N/A & 892 & 275 & 2.35 & 23.82 & $\mathbb{N} / \mathrm{A}$ & $8.8 \times 10^{-7}$ & $2.40 \times 10^{-7}$ & $4.08 \times 10^{-5}$ \\
\hline $6448-01-010$ & SI-BISO & $\mathrm{vc}_{0.49^{\circ}}{ }_{1.12}$ & 359 & 123 & 0.93 & None & 47 & 1.84 & $\mathrm{~N} / \mathrm{A}$ & $N / A$ & $\mathrm{~N} / \mathrm{A}$ & 113 & 2.07 & N/A & 928 & 285 & 2.33 & 23.00 & $\mathbb{N} / \mathbf{A}$ & $1.0 \times 10^{-7}$ & $1.7 \times 10^{-7}$ & $1.97 \times 10^{-5}$ \\
\hline $6448-00-010$ & Si-BISO & $\mathrm{Uc}_{0.20^{0}}{ }_{1.64}$ & 369 & 136 & 0.93 & None & 43 & 1.92 & $\mathrm{~N} / \mathrm{A}$ & $\mathrm{N} / \mathrm{A}$ & $\mathrm{N} / \mathrm{A}$ & 116 & 2.07 & N/A & 951 & 291 & 2.33 & 22.84 & $\mathrm{n} / \mathrm{A}$ & $4.5 \times 10^{-7}$ & $3.1 \times 10^{-7}$ & $2.31 \times 10^{-5}$ \\
\hline $6447-00-010$ & Si-Brso & & 301 & 116 & 1.10 & None & 32 & 1.95 & $\mathrm{~N} / \mathrm{A}$ & $\mathrm{N} / \mathrm{A}$ & $\mathrm{N} / \mathrm{A}$ & 120 & 2.14 & N/A & 833 & 266 & 2.45 & 18.39 & $\mathrm{~N} / \mathrm{A}$ & $1.3 \times 10^{-7}$ & $1.7 \times 10^{-7}$ & $4.44 \times 10^{-5}$ \\
\hline $6447-01-010$ & SI-BISO & $v 0_{2}^{*} \mathrm{c}$ & 316 & 98 & 1.22 & Yes & 35 & 1.91 & $\mathrm{~N} / \mathrm{A}$ & $\mathrm{N} / \mathrm{A}$ & $\mathrm{N} / \mathrm{A}$ & 114 & 2.11 & $N / A$ & 825 & 254 & 2.43 & 19.90 & $\mathrm{~N} / \mathrm{A}$ & $5.1 \times 10^{-7}$ & 0 & $1.36 \times 10-5$ \\
\hline $6447-02-010$ & Si-BISO & $\cos _{2}^{*}(\mathrm{~g})$ & 312 & 82 & 0.91 & Yes & 35 & 1.92 & $\mathrm{~N} / \mathrm{A}$ & $\mathrm{N} / \mathrm{A}$ & N/A & 118 & 2.14 & N/A & 830 & 255 & 2.37 & 20.12 & $\mathrm{~N} / \mathrm{A}$ & $4.0 \times 10^{-7}$ & $3.18 \times 10^{-7}$ & $4.85 \times 10^{-5}$ \\
\hline $6447-02-020$ & Si-BISO & $\operatorname{\omega o}_{2}^{*}(\mathrm{~h})$ & 311 & 93 & 0.87 & Yes & 39 & 1.84 & $\mathrm{~N} / \mathrm{A}$ & $N / \mathrm{A}$ & N/A & 113 & 2.11 & $\mathrm{~N} / \mathrm{A}$ & 836 & 262 & 2.38 & 18.53 & $\mathbb{N} / \mathrm{A}$ & $3.0 \times 10^{-7}$ & $2.70 \times 10^{-7}$ & $2.13 \times 10^{-5}$ \\
\hline $6449-00-010$ & Si-BISO & $\mathrm{uc}_{2}$ & 348 & 117 & 0.94 & None & 37 & 1.86 & $\mathrm{~N} / \mathrm{A}$ & $\mathrm{N} / \mathrm{A}$ & $\mathrm{N} / \mathrm{A}$ & 117 & 2.17 & $N / A$ & 881 & 268 & 3.36 & 23.89 & $\mathbb{N} / \mathrm{A}$ & $1.0 \times 10^{-7}$ & $2.6 \times 10^{-7}$ & $2.74 \times 10^{-5}$ \\
\hline $6542-42-010$ & Si-BISO & $\mathrm{ThO}_{2}$ & 509 & 55 & 1.05 & Yes & N/A & $\mathrm{N} / \mathrm{A}$ & $\mathrm{N} / \mathrm{A}$ & $\mathrm{N} / \mathrm{A}$ & N/A & 76 & 2.19 & N/A & 773 & 131 & 3.69 & $\mathrm{x} / \mathrm{A}$ & 58.42 & $1.2 \times 10^{-5}$ & $3.79 \times 10^{-7}$ & $1.01 \times 10^{-5}$ \\
\hline $6542-42-020$ & SE-BISO & $\mathrm{ThO}_{2}$ & 447 & 65 & 1.16 & Yes & $\mathrm{N} / \mathrm{A}$ & $\mathrm{N} / \mathrm{A}$ & $\mathrm{N} / \mathrm{A}$ & $\mathrm{N} / \mathrm{A}$ & $\mathrm{N} / \mathrm{A}$ & 76 & 2.22 & N/A & 728 & 141 & $w / p^{(e)}$ & $\mathrm{N} / \mathrm{s}$ & 54.29 & $7.4 \times 10-6$ & $n / D$ & $\mathrm{~N} / \mathrm{D}$ \\
\hline $6542-27-010$ & Biso & $\mathrm{ThO}_{2}$ & 512 & 84 & 1.09 & None & N/A & $\mathrm{N} / \mathrm{A}$ & $\mathrm{N} / \mathrm{A}$ & $\mathrm{N} / \mathrm{A}$ & $\mathrm{N} / \mathrm{A}$ & 81 & 1.86 & 1.027 & 836 & 164 & 3.45 & $\mathrm{~s} / \mathrm{A}$ & 56.70 & $1.20 \times 10^{-5}$ & $1.92 \times 10^{-8}$ & $3.73 \times 10^{-6}$ \\
\hline $6351-05-010$ & Triso & Inert & $420-595^{(1)}$ & 97 & $\mathrm{w} / \mathrm{D}$ & None & $131^{(j)}$ & $\mathrm{N} / \mathrm{A}$ & 1.038 & 34 & 3.17 & 44 & $1.90^{(j)}$ & 1.024 & 1061 & $\mathrm{~N} / \mathrm{A}$ & $1.95(k)$ & $\mathrm{N} / \mathrm{A}$ & $\mathrm{N} / \mathrm{A}$ & N/A & N/A & $\mathrm{N} / \mathrm{A}$ \\
\hline $6351-05-020$ & ristso & Inert & $420-595^{(1)}$ & 97 & $\mathrm{~N} / \mathrm{D}$ & None & $123^{(j)}$ & $\mathrm{N} / \mathrm{A}$ & $\mathrm{N} / \mathrm{A}$ & 34 & $\mathrm{~N} / \mathrm{D}$ & 40 & $2.12^{(j)}$ & N/A & 1037 & N/A & $1.97^{(k)}$ & $\mathrm{N} / \mathrm{A}$ & $\mathrm{N} / \mathrm{A}$ & $\mathrm{N} / \mathrm{A}$ & N/A & $\mathrm{N} / \mathbf{A}$ \\
\hline $6351-05-030$ & TRkiso & Inert & $420-595^{(1)}$ & 97 & $\mathrm{~N} / \mathrm{D}$ & None & $120^{(j)}$ & $\mathrm{N} / \mathrm{A}$ & $\mathrm{N} / \mathrm{A}$ & 36 & 3.17 & 23 & $1.94^{(j)}$ & N/A & 1003 & $\mathrm{~N} / \mathrm{A}$ & $1.98^{(k)}$ & $\mathrm{N} / \mathrm{A}$ & $\mathrm{W} / \mathrm{A}$ & $\mathrm{N} / \mathrm{A}$ & N/A & $\mathrm{N} / \mathrm{A}$ \\
\hline $6351-05-040$ & rRIso & Inerr & $420-595^{(1)}$ & 97 & $\mathrm{~N} / \mathrm{D}$ & None & $240^{(j)}$ & $\mathrm{N} / \mathrm{A}$ & $\mathrm{N} / \mathrm{A}$ & 48 & 3.21 & 46 & $1.83^{(j)}$ & $\mathrm{N} / \mathrm{A}$ & 1312 & N/A & $1.97^{(k)}$ & $\mathrm{N} / \mathrm{A}$ & $\mathrm{N} / \mathrm{A}$ & $\mathrm{N} / \mathrm{A}$ & $\mathrm{N} / \mathrm{A}$ & $\mathrm{N} / \mathrm{A}$ \\
\hline $6351-05-050$ & TRISO & Inert & $420-595^{(1)}$ & 97 & $\mathrm{x} / \mathrm{D}$ & None & $226^{(j)}$ & $\mathrm{N} / \mathrm{A}$ & $\mathrm{N} / \mathrm{A}$ & 47 & 3.22 & 43 & $2.08^{(f)}$ & $\mathrm{N} / \mathrm{A}$ & 1276 & $\mathrm{~N} / \mathrm{A}$ & $2.00^{(k)}$ & $\mathrm{N} / \mathrm{A}$ & $\mathrm{N} / \mathrm{A}$ & $\mathrm{N} / \mathrm{A}$ & $\mathrm{N} / \mathrm{A}$ & $\mathrm{N} / \mathrm{A}$ \\
\hline $6351-05-060$ & IRISO & Inert & $420-595^{(1)}$ & 97 & $\mathrm{~N} / \mathrm{D}$ & None & $230^{(\mathrm{j})}$ & N/A & $\mathrm{N} / \mathrm{A}$ & 46 & 3.22 & 37 & $2.09^{(j)}$ & N/A & 1270 & $\$ / \mathrm{A}$ & $2.02^{(k)}$ & $\mathrm{N} / \mathrm{A}$ & $\mathrm{N} / \mathrm{A}$ & $N / A$ & $\mathrm{~N} / \mathrm{A}$ & N/A \\
\hline
\end{tabular}

(a) All the fissile batches were coated to the IPyC stage, then split into two groups; one group recelved a S1C and OPyC layer, beconing a rRIso batch; the second group recelved a silicon-doped opyC 1ayer and became the

(c) TRISO coatings consist of a SIC layer sandwiched between inner and outer PyC layers; BISO coatings have no SiC layer and only one PyC layer; S1-BISO reters to a BISO coating having the PyC Iayer doped with s1iicon. (c) BAF $_{\mathrm{O}}=$ Bacon antsotropy factor (optical), relative units.

(d) Release/birth rate for $\mathrm{Kr}-85 \mathrm{~m}$ at $1100^{\circ} \mathrm{C}$; fissile particles were measured in TRIGA, fertile particles in LINAC.

$(\mathrm{e}) \mathrm{N} / \mathrm{A}=$ not applicabie; $N / \mathrm{D}=$ not deterwined.

(f) This particle type had a $2 \mathrm{rC}$-doped buffer layer; a seal coat was app11ed between the kernel and buffer to prevent contanination of the kernel.

(g) Th1s particle type had a 5- par-thick ZxC layer app11ed to the kerne1; a seel coat was used between the kerne1 and 2rC layer to prevent contanination of the kernel.

(1) This particle type had a $10-$ un-thick $2 \times C$ layer applied to the kerne1; a seal coat was used between the kernel and $2 r C$ layer to prevent contanination of the kernel.

(1) Determined by sieve analysis.

(j) Calculated nurbers.

(k) Sink/float densities. 


\section{CAPSULE OPERATION}

The capsule was installed in the ORNL HFIR on July 5, 1978. The first fu11-power cycle began at 1615 on July 6, 1978 without incident. Since particle heat rates are severe during the initial experiment phase, the capsule was swept with $100 \%$ helium throughout the entire first cycle. Neon was gradually added to the primary sweep gas during subsequent cycles to achieve design temperatures. Table 3-1 gives the HFIR cycle numbers during which HRB-15B was irradiated and the accumulated in-pile hours for the test.

While the capsule operated without difficulty throughout the entire irradiation, early in the test, the capsule was found to be improperly centered relative to the horizontal midplane of the HFIR, because the upper capsule portion was operating cooler than expected, while the lower portion was running hotter than expected. During the reactor shutdown between cycles 166 and 167 (September 13 through 15, 1978), the irradiation facility was modified to lower the capsule $-20 \mathrm{~mm}$. Upon return to power, the axial temperature distribution in the capsule was much more symmetrical and very close to what was expected for that time in the irradiation. Section 4 discusses the implication of this discrepancy on fuel temperatures and exposure levels.

The capsule sweep gas was periodically sampled for short-lived gaseous fission products to monitor release from failed fuel particles. The five isotopes measured were $\mathrm{Kr}-85 \mathrm{~m}, \mathrm{Kr}-87, \mathrm{Kr}-88$, $\mathrm{Xe}-133$, and $\mathrm{Xe}-135$. Table 3-2 gives the results and indicates that the failure level remained low during the irradiation period. Since all fuel samples were swept with the same temperature control gas, this information cannot be used to infer failure levels for specific fuel types in the test. 
After eight full reactor cycles, capsule $H R B-15 B$ was removed from the HFIR on January 4, 1979 without incident. The experiment was in the reactor for 182.1 calendar days. The cumulative full power days of operation were 169.4 [i.e., the equivalent calendar days with HFIR operating at rated power of $100 \mathrm{MW}(t)]$. 
TABLE 3-1

REACTOR OPERATING HISTORY DURING HRB-15B IRRADIATION

\begin{tabular}{|c|c|c|c|c|c|c|}
\hline \multirow{3}{*}{$\begin{array}{r}\text { HFIR } \\
\text { Cycle } \\
\end{array}$} & \multicolumn{4}{|c|}{ Cycle Schedule } & \multicolumn{2}{|c|}{$\begin{array}{c}\text { Irradiation Time (a) } \\
(\mathrm{h})\end{array}$} \\
\hline & \multicolumn{2}{|c|}{ Begin } & \multicolumn{2}{|c|}{ End } & \multirow{2}{*}{$\begin{array}{c}\text { In } \\
\text { Cycle }\end{array}$} & \multirow{2}{*}{$\begin{array}{c}\text { Total } \\
\text { Accumulated }\end{array}$} \\
\hline & Date & Time & Date & Time & & \\
\hline $164^{(b)}$ & $7 / 6 / 78$ & 1615 & $7 / 30 / 78$ & 2350 & 515 & 515 \\
\hline 165 & $7 / 31 / 78$ & 1752 & $8 / 22 / 78$ & 0100 & 510 & 1025 \\
\hline 166 & $8 / 22 / 78$ & 1909 & $9 / 13 / 78$ & 0400 & 513 & 1538 \\
\hline 167 & $9 / 15 / 78$ & 1824 & $10 / 6 / 78$ & 2115 & 506 & 2044 \\
\hline 168 & $10 / 7 / 78$ & 1650 & $10 / 29 / 78$ & 0000 & 511 & 2555 \\
\hline $169^{(c)}$ & $10 / 29 / 78$ & 1735 & $11 / 22 / 78$ & 0225 & 502 & 3057 \\
\hline 170 & $11 / 22 / 78$ & 2147 & $12 / 14 / 78$ & 0140 & 507 & 3564 \\
\hline 171 & $12 / 14 / 78$ & 1945 & $1 / 4 / 79$ & 1759 & 502 & 4066 \\
\hline
\end{tabular}

(a) Irradiation time is given in equivalent hours at $100 \mathrm{MW}$.

(b) Reactor was shut down from 2100, Ju1y 24, 1978 to 1408 , July 27, 1978. The reactor also operated at reduced power on numerous occasions during this cycle due to weather conditions.

(c) Reactor was shut down from 0815, November 13, 1978 to 1830, November 15,1978 . 
TABLE 3-2

CAPSULE HRB-15B IN-PILE FISSION GAS RELEASE

\begin{tabular}{|c|c|c|c|c|c|c|c|}
\hline \multirow{2}{*}{$\begin{array}{l}\text { Sample } \\
\text { No. }\end{array}$} & \multirow[b]{2}{*}{ Date } & \multirow{2}{*}{$\begin{array}{l}\text { Accumulated } \\
\text { Irradiation } \\
\text { Time }(\mathrm{h})\end{array}$} & \multicolumn{5}{|c|}{ In-pile Fission Gas Release ( $\mathrm{R} / \mathrm{B} \times 10^{-7}$ ) } \\
\hline & & & $\mathrm{Kr}-85 \mathrm{~m}$ & $\mathrm{Kr}-87$ & $\mathrm{Kr}-88$ & $\mathrm{Xe}-135$ & $\mathrm{Xe}-133$ \\
\hline 1 & $7 / 13 / 78$ & 167 & 0.29 & 0.21 & 0.17 & (a) & (a) \\
\hline 2 & $7 / 21 / 78$ & 358 & 0.40 & 0.31 & 0.18 & 0.46 & 0.63 \\
\hline 3 & $8 / 4 / 78$ & 609 & 0.85 & 0.47 & 0.45 & 0.80 & 1.74 \\
\hline 4 & $8 / 15 / 78$ & 874 & 0.83 & 0.48 & 0.44 & 0.94 & 2.08 \\
\hline 5 & $9 / 12 / 78$ & 1521 & 0.72 & 0.57 & 0.40 & 0.97 & 2.16 \\
\hline 6 & $9 / 20 / 78$ & 1654 & 1.00 & 0.69 & 0.57 & (a) & 5.24 \\
\hline 7 & $9 / 26 / 78$ & 1800 & 0.80 & 0.56 & 0.45 & (a) & 2.12 \\
\hline 8 & $10 / 4 / 78$ & 1986 & 0.77 & 0.52 & 0.45 & 1.09 & 2.11 \\
\hline 9 & $10 / 11 / 78$ & 2135 & 0.92 & 0.60 & 0.57 & 1.06 & 2.38 \\
\hline 10 & $10 / 17 / 78$ & 2278 & 1.03 & 0.58 & 0.62 & 1.07 & 2.86 \\
\hline 11 & $10 / 26 / 78$ & 2491 & 1.16 & 0.53 & 0.63 & 1.02 & 5.08 \\
\hline 12 & $11 / 1 / 78$ & 2619 & 2.03 & 0.86 & 1.05 & (a) & (a) \\
\hline 13 & $11 / 7 / 78$ & 2763 & 3.75 & 1.30 & 1.75 & 0.96 & 17.90 \\
\hline 14 & $11 / 21 / 78$ & 3040 & 6.08 & 1.90 & 2.94 & 1.06 & 23.30 \\
\hline 15 & $12 / 4 / 78$ & 3335 & 10.30 & 3.25 & 4.61 & 1.14 & 41.10 \\
\hline 16 & $12 / 13 / 78$ & 3553 & 12.00 & 3.55 & 5.29 & 1.22 & 64.00 \\
\hline 17 & $12 / 21 / 78$ & 3724 & 20.60 & 5.28 & 8.85 & 0.92 & 138.00 \\
\hline 18 & $12 / 28 / 78$ & 3892 & 36.40 & 8.46 & 17.60 & 1.43 & 176.00 \\
\hline 19 & $1 / 4 / 79$ & 4055 & 50.80 & 10.20 & 24.00 & 1.13 & 238.00 \\
\hline
\end{tabular}

(a) No value was reported. 


\section{THERMAL ANALYSIS AND FUEL BURNUP DETERMINATIONS}

\subsection{THERMAL ANALYSIS}

Capsule $H R B-15 B$ was thermally designed to irradiate fuel particles at $\sim 1000^{\circ} \mathrm{C}$. Eight chrome1-alumel thermocouples monitored temperatures throughout the test, and the inert sweep gas mixture which continuously purged the experiment was adjusted to control temperature over a wide range.

The Core Materials Organization at GA performed a simplified thermal analysis after the irradiation to determine the fuel particle temperature histories. This capsule was inherently less complex from a thermal analysis standpoint than the typical HRB capsule because of its construction and thermocouple placement. Most HRB capsules have a graphite sleeve which contains the fuel samples and the thermocouples. A thin gap, swept continuously with the control gas, separates the fuel from the sleeve and provides a large percentage of the temperature difference between the fuel samples and the reactor coolant. This same gap, however, is also responsible for large uncertainties $\left(100^{\circ}\right.$ to $\left.200^{\circ} \mathrm{C}\right)$ in the calculated fuel temperatures. Capsule HRB-15B had no graphite sleeve. Instead, two thermocouples were located in each subassembly at the inner tray circumferences (see Fig. 2-2) so that they indicated tray temperatures directly. This absence of a temperature control gap between the fuel and thermocouples and the use of highconductivity POCO graphite, which minimized axial temperature gradients within the subassemblies, combined to reduce the overall uncertainty in the calculated fuel particle temperatures in HRB-15B. 
ORNL personnel have studied the geometry of a spherical particle in a hole and modeled it with several computer codes (Ref. 2). As a result of this work, the following relationship was formulated for this capsule:

$$
\Delta \mathrm{T}_{\max }=\mathrm{P}\left(\mathrm{G}_{1}-\overline{\mathrm{T}}\right) / \mathrm{G}_{2},
$$

where $\Delta \mathrm{T}_{\max }=$ temperature difference $\left({ }^{\circ} \mathrm{C}\right)$ between the point of maximum temperature on the particle surface and the mean tray temperature, $P=$ particle fission heat rate $(W)$, $\overline{\mathrm{T}}=$ mean graphite tray temperature $\left({ }^{\circ} \mathrm{C}\right)$, $\mathrm{G}_{1}, \mathrm{G}_{2}=$ unitless constants related to sweep gas composition.

The temperatures varied over the particle surfaces from minimum values at the points of contact with the trays to maximum values near the tops of the particles. Since ORNL had reported maximum particle surface temperatures for unbonded particle samples, such as in the HT capsules, for comparison, this was also done with the HRB-15B particles.

Since the maximum particle surface temperatures were functions of parameters that were continuously changing throughout the irradiation, a rigorous thermal analysis would have required calculations for each day of operation. These values would then be averaged to obtain the time-averaged maximum particle surface temperatures for each tray location in the capsule. The simplified approach taken here was to time-average the various components in Eq. 4-1 and to assume that a11 the particle trays in each subassembly ran at the same temperature. This latter assumption was not a significant compromise in accuracy because of the high conductivity graphite components which minimized the temperature gradients. This was verified by the sma11 differences in the time-averaged thermocouple readings within each 
subassembly, which were $19^{\circ}, 8^{\circ}, 1^{\circ}$, and $2^{\circ} \mathrm{C}$, respectively, for subassemb1ies 1 through 4 . The time-averaged parameters used in Eq. 4-1 were

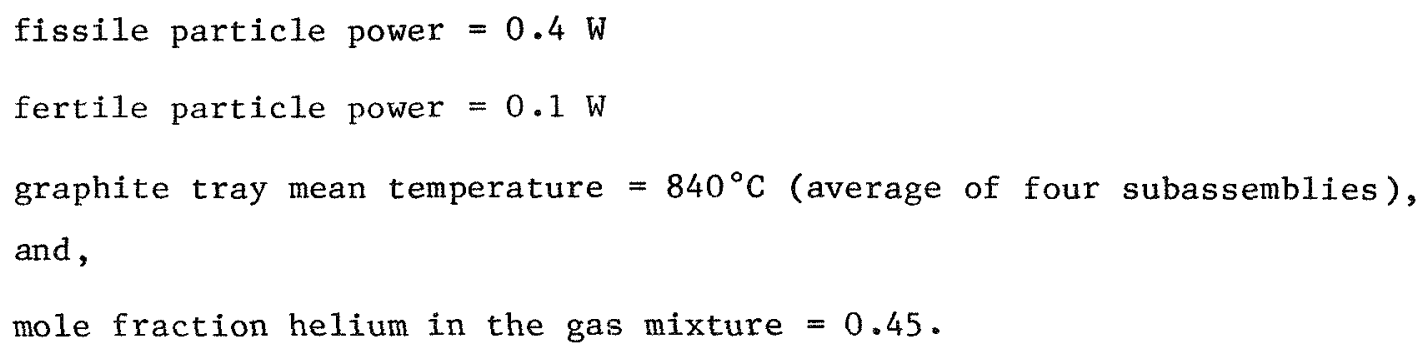

This gives values for $G_{1}$ and $G_{2}$ of 2840 and 13.3 , respectively (Ref. 2).

Using these values in Eq. 4-1 gives $\Delta T_{\max } \simeq 60^{\circ} \mathrm{C}$ for fissile particles and $\Delta \mathrm{T}_{\max } \simeq 15^{\circ} \mathrm{C}$ for fertile particles. These values were then added to the time-averaged graphite tray temperatures for each subassembly to obtain the time-averaged maximum particle surface temperatures for the fuel particles. These are listed in Appendix A for all capsule samples. These values have been averaged to the nearest $5^{\circ} \mathrm{C}$ increments. The $2 \sigma(95 \%$ confidence) uncertainty in the time-average maximum particle surface temperatures was calculated to be $\sim 50^{\circ} \mathrm{C}$ by a propagation of errors technique. Appendix $B$ shows this calculation.

Figures 4-1 through 4-4 plot the graphite tray temperature histories for each of the four subassemblies. To obtain these histories, the thermocouple readings were first organized into one reading per thermocouple per day of operation. This required averaging values where more than one reading was taken per day or where no readings were taken on some days. The data for thermocouple No. 8 had to be inferred from the thermocouple No. 7 readings during most of the first two cycles due to an unexplained malfunction in this unit. The values for the two thermcouples in each subassembly were averaged and considered to be the tray temperatures in that subassembly for each day of operation. These values were then time-averaged over the irradiation period, shown by the dotted lines in Figs. 4-1 through 4-4. 
The plots show low temperatures in the first cycle, when pure helium sweep gas was used. The low temperatures near the beginning of each cycle resulted, because only helium was run through the capsule until xenon equilibrium was attained.

Adjusting the capsule position in the reactor after the third cycle (see arrows in Figs. 4-1 through 4-4) definitely changed the temperature, especia1ly in subassemblies 1 and 2. This position change did not affect the temperatures of subassemblies 3 and 4 , because they were nearer the horizontal midplane (where the flux profile is not as steep) before the ad justment.

\subsection{FUEL BURNUP DETERMINATIONS}

Determining fuel particle burnups [percent fissions per initial metal atom (FIMA)] of selected capsule HRB-15B particles was a relatively small part of the GA Analytical Chemistry Department effort to measure FIMAs and heavy metal reaction rates for LEU fuel particles irradiated in the RB position of the HFIR facility. This program characterized fuel particles from both capsules HRB-14 (Ref. 3) and HRB-15B, which contained the first LEU fuel types tested in the HFIR. Since most work involved HRB-14 sample measurements and calculations (see the Appendix of Ref. 3 for complete details) applicable to the HRB-15B samples, these calculations and measurements were not repeated in this $\mathrm{PIE}$.

The HRB-15B particle burnup analysis was predominantly calculated rather than measured. Although the particles were analyzed by gamma-ray spectrometry, no other radiochemical analyses were performed on these samples. The computational method used the CURIE computer program. Table 4-1 compares final calculated results with the gamma-ray spectrometry measurements. The agreement between the measured and calculated isotopic ratios was nominally within $10 \%$, providing confidence in these results. Based on this agreement, the other computed values regarding heavy metal depletion and FIMA should be equally as good. The fluxes used in the 
calculations considered the change in capsule position at the end of the third reactor cycle (see Section 3).

Based on the burnups determined for the selected particles, curve fits were generated for the entire capsule length which give the fissile and fertile FIMAs for all fuel particle locations in the test. Appendix A shows these curves and plots the fast fluence relationship for the capsule. Notice that these curves are not exactly symmetric about the capsule midplane as a result of the capsule movement already mentioned. Appendix A also tabulates the exposure conditions of burnup, fast fluence, and irradiation temperature for all particle tray locations in the capsule in Tables A-1 through A-4. 


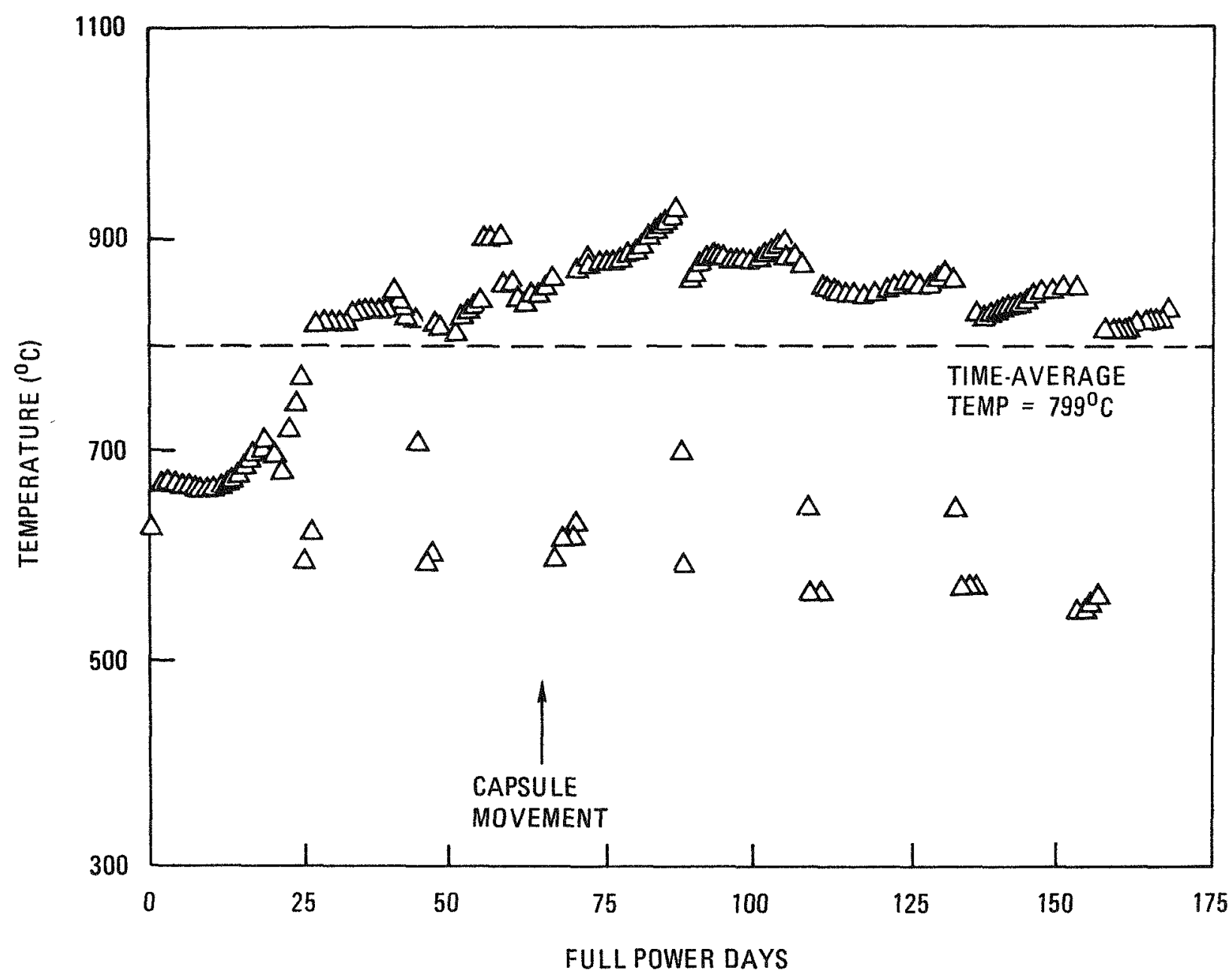

Fig. 4-1. Capsule HRB-15B subassembly 1 graphite tray temperature history 


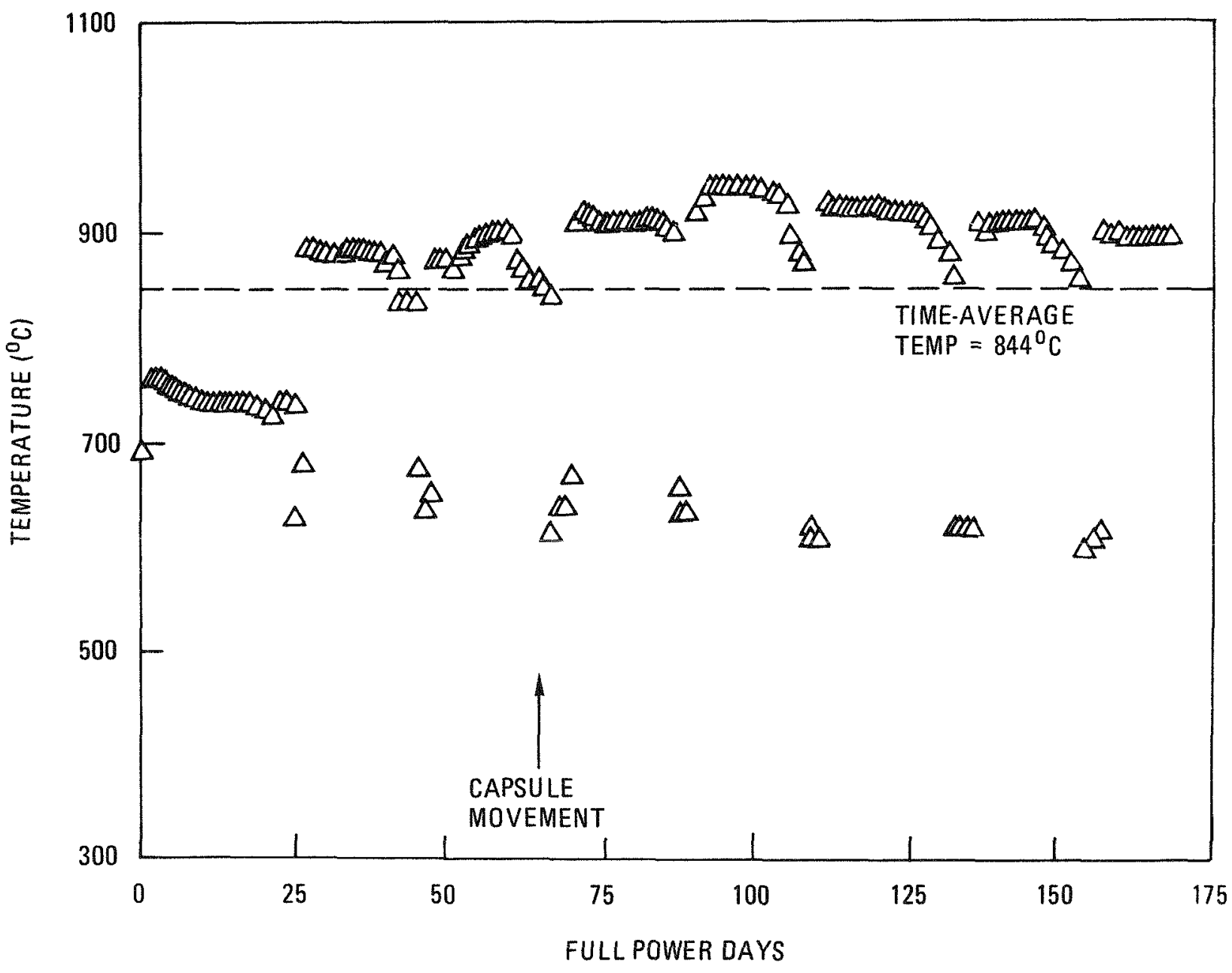

Fig. 4-2. Capsule HRB-15B subassembly 2 graphite tray temperature history 


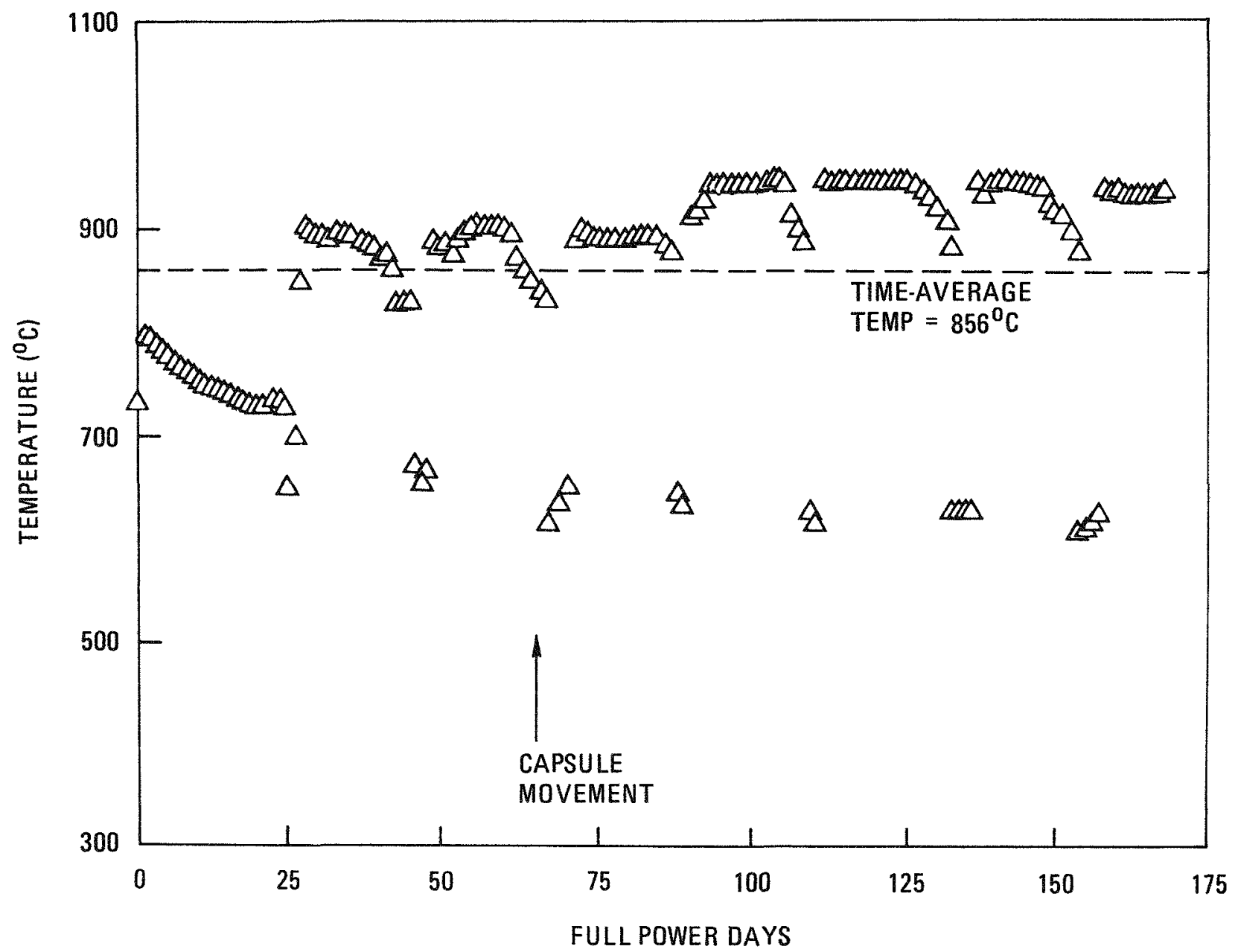

Fig. 4-3. Capsule HRB-15B subassembly 3 graphite tray temperature history 


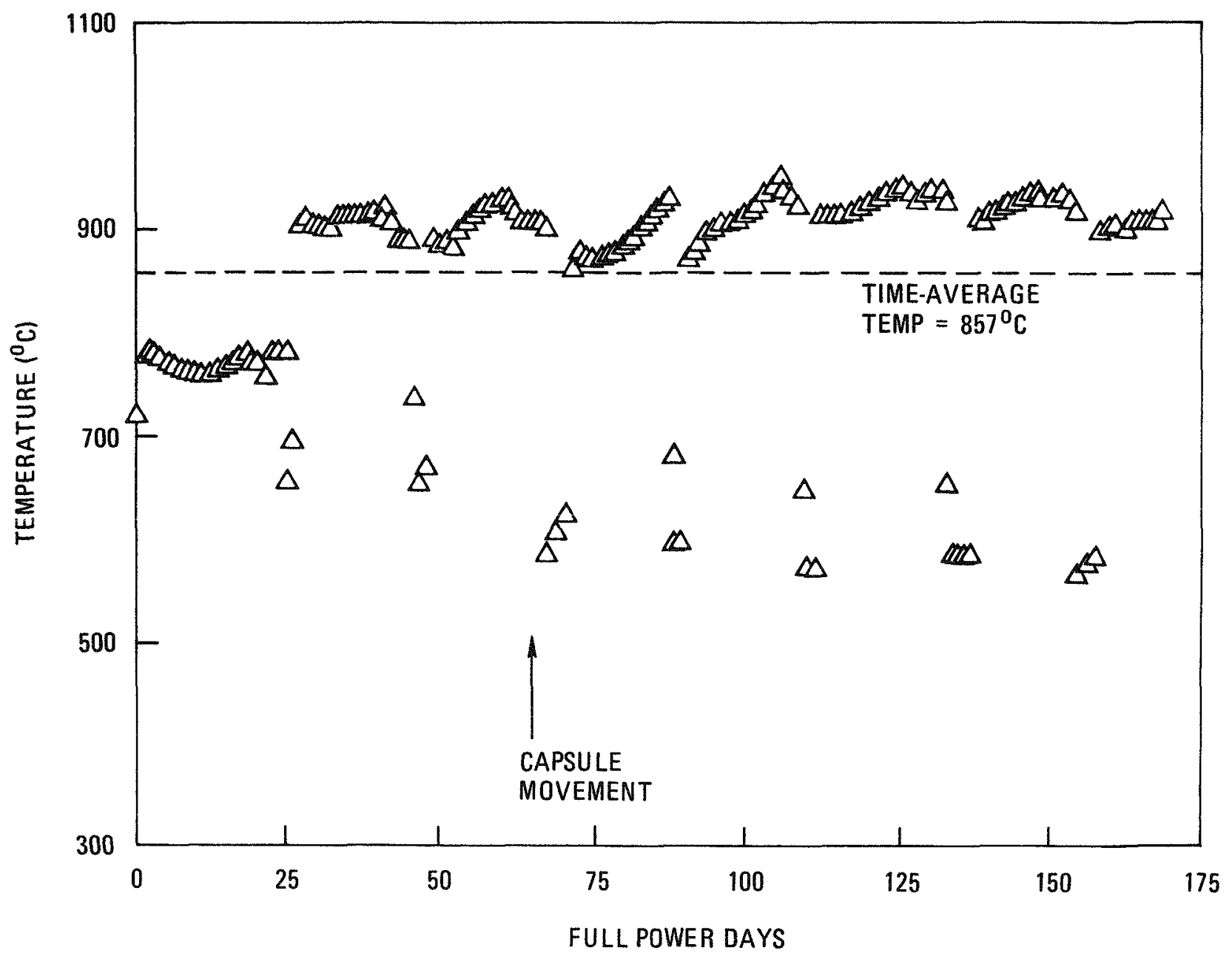

Fig. 4-4. Capsule HRB-15B subassembly 4 graphite tray temperature history 
TABLE 4-1

HRB-15B ISOTOPIC RATIOS AND CALCULATED BURNUP VALUES

\begin{tabular}{|c|c|c|c|c|c|c|c|c|c|c|c|}
\hline \multirow{3}{*}{$\begin{array}{l}\text { Tray } \\
\text { No. }\end{array}$} & \multicolumn{10}{|c|}{ Isotopic Ratios } & \multirow{3}{*}{$\begin{array}{c}\text { Calculated } \\
\text { Kernel } \\
\text { Burnup } \\
\text { (\% FIMA) (c) }\end{array}$} \\
\hline & \multicolumn{2}{|c|}{$\mathrm{Cs}-137 / \mathrm{Ru}-106$} & \multicolumn{2}{|c|}{$\mathrm{Cs}-137 / \mathrm{Cs}-134$} & \multicolumn{2}{|c|}{$\mathrm{Cs}-137 / \mathrm{Ru}-103$} & \multicolumn{2}{|c|}{$\mathrm{Zr}-95 / \mathrm{Ru}-103$} & \multicolumn{2}{|c|}{$\mathrm{Pa}-233 / \mathrm{Cs}-137$} & \\
\hline & Measured (a) & Calculated $(b)$ & Measured & Calculated & Measured & Calculated & Measured & Calculated & Measured & Calculated & \\
\hline 145 & - & - & 10.75 & 11.17 & 9.36 & 9.08 & 4.63 & 4.60 & 4.87 & 5.08 & 4.51 \\
\hline 148 & 4.09 & 4.25 & 6.12 & 5.95 & 6.37 & 6.70 & 1.56 & 1.83 & -- & - & $24 \cdot 30$ \\
\hline 104 & 3.55 & 3.63 & 5.84 & 5.41 & 6.02 & 6.16 & 1.42 & 1.63 & - & - & 26.70 \\
\hline 105 & - & - & 9.51 & 9.49 & 9.33 & 8.93 & 4.46 & 4.50 & 4.34 & 4.62 & 6.00 \\
\hline 174 & 4.66 & 5.02 & 7.13 & 7.03 & 6.85 & 7.01 & 1.73 & 2.04 & -- & -- & 21.60 \\
\hline 181 & - & - & 14.45 & 15.49 & 8.92 & 9.13 & 4.41 & 4.70 & 5.99 & 6.09 & 2.66 \\
\hline 38 & 4.43 & 4.29 & 6.54 & 6.10 & 6.60 & 6.33 & 1.69 & 1.82 & -- & - & 23.40 \\
\hline 12 & 4.65 & 5.13 & 7.57 & 7.39 & 6.29 & 6.45 & 1.98 & 2.03 & -- & -- & 20.50 \\
\hline 15 & - & - & 15.44 & 14.01 & 9.42 & 8.75 & 4.66 & 4.64 & 6.43 & 6.54 & 2.78 \\
\hline 84 & 3.51 & 3.64 & 5.95 & 5.41 & 6.07 & 6.10 & 1.43 & 1.63 & - & -- & 26.60 \\
\hline 87 & -- & - & 9.21 & 9.44 & 9.15 & 8.84 & 4.46 & 4.48 & 4.47 & 4.70 & 5.99 \\
\hline
\end{tabular}

(a) Measured by gamma-spectrometry.

(b) Calculated with the GA CURIE program.

(c) These calculated values do not agree exactly in all cases with the burnups listed in Appendix A, since the latter values were obtained by curve-fitting the calculated values shown here. 


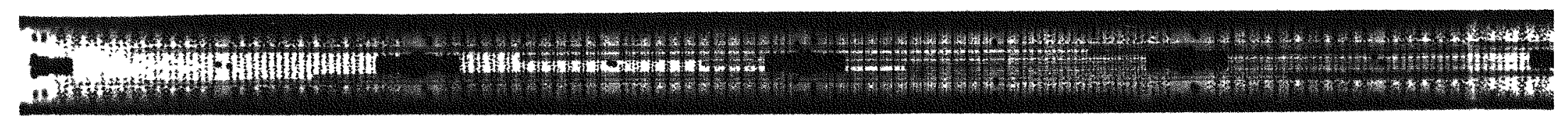

Fig. 2-4. Preirradiat fon x-radiograph of HRB-15B, after encapsulation 


\section{POSTIRRADIATION EXAMINATIONS}

\subsection{CAPSULE REMOVAL AND DISASSEMBLY}

The capsule was removed from the reactor on January 4, 1979 after eight full cycles of irradiation and was stored for one week in a pool at the HFIR facility. Following this initial cooldown, the capsule was transferred to the hot cells at ORNL, where it was stored until Apri1 2, 1979, when the disassembly began. A gamma scan of the capsule following removal from the reactor (Fig. 5-1) showed an activity profile that matched the HFIR flux pattern and indicated that no breakage or movement of fuel samples or capsule components had occurred during irradiation. The activities due to the fuel samples at each tray position are easily distinguished in the gamma scan. Interestingly, the fertile particle locations show the higher activity at this point because of the presence of Pa-233 with a 27 -day half-life (this gamma scan was done on January 22, 1979, 18 days after removal from the HFIR).

The disassembly began with two circular cuts being made through the primary and secondary containments at the top of the capsule, $10.16 \mathrm{~cm}$ ( 4 in.) above the first subassembly and at the bottom just below the end of subassembly 4. The original intentions were to first extract the thermocouple cluster from the subassembly stack, then push the subassemblies out of the containment tubes. The thermocouples could not be pulled free, however, with a moderate amount of force, so the entire assembly was pulled out. Subassembly 4 remained in the tube and had to be pushed out separately. Once the entire assembly was out of the containments, the thermocouples could be removed one by one, and the four subassemblies were free. A white paint stripe was applied along the length of each subassembly and referenced to the angular location of the longest thermocouple in the capsule, thermocouple No. 8. This was done so that the relative angular 
location of each particle tray could be known during visual examination with the particles still in place in the trays. Figure 5-2 shows subassembly 3 after removal from the capsule and application of the paint stripe.

Each of the four subassemblies was then dismantled to retrieve the capsule fuel samples. A specially fabricated set of tools (Fig. 5-3) were used to remove the end disks and center spines from each subassembly, leaving a stack of 46 loaded particle trays. The trays with particles in place were then removed one by one and placed in aluminum holders, which could accommodate 12 loaded graphite disks each. The capsule fuel samples could then be handled and transported with a minimal risk of spillage or loss of particles.

The subassembly center spines and all the GA-loaded particle trays were shipped to the GA hot cell on May 1, 1979 for continued PIF. Then, the last two disassembly steps were done (removing all particles from their graphite irradiation trays and removing the inert particles from the subassembly center spines).

Because the new HRB-15B design was the first time that an HRB capsule had consisted of many unbonded particle samples, problems were encountered during the disassembly. Particles from several trays were spilled and mixed during the subassembly dismantling. Some particles were crushed in the aluminum shipping trays when the lids were tightened in place. (Particles sometimes shifted so that two occupied the same tray hole, interfering with the shipping tray lid so that the particles were crushed.) One aluminum holder lid loosened during shipment from ORNL to GA, and many particles spilled and had to be discarded. In all, 900 of the 11,552 GA particles were lost either during disassembly or shipment. Fortunately, many trays of most fuel types were available so that no one particle batch or coating type was entirely lost. 


\subsection{VISUAL EXAM DETAILS}

Upon removal from the reactor, the exterior containment surface had no evident unusual features. No cracks, breaks, or other indications of damage were seen on any of the capsule components, including the thermocouples and subassemblies when they were removed from the containment tubes. The subassemblies differed from their preirradiation condition only by an apparent carburization of the stainless steel screws holding the assemblies together. This may explain why these screws were difficult to remove during disas sembly.

A11 GA fuel particles were visually examined both in the graphite trays and after removal from the trays. Figure 5-4 shows a typical graphite tray with the irradiated particles in place. Figure 5-5 shows the same particles after removal from the tray. Figures $5-6$ and 5-7 show the TRISO $\mathrm{ThO}_{2}$ particles irradiated in tray No. 93 before and after removal from the tray. Figures 5-8 and 5-9 show typical examples of silicon-BISO-coated irradiated particles as they appeared during visual exam. Visual examination showed no irradiation-induced failures in any of the GA fuel particle batches tested in $\mathrm{HRB}-15 \mathrm{~B}$. Specifically, no pressure vessel failures, and no OPyC spalling or cracking was seen. The very few broken particles observed had been crushed in the aluminum shipping holders, as discussed in section 5.1 .

OPyC failures were observed in the TRISO-coated inert piggyback samples, however. Table 5-1 gives the visual exam results for each inert batch tested.

\subsection{DIMENSIONAL CHANGE OF GRAPHITE PARTICLE DISKS}

A11 the particle trays and other subassembly parts in $H R B-15 B$ were made of POCO AFX-9Q graphite. The diameters of selected particle trays were measured after irradiation to compare with preirradiation values. After the irradiated particles were removed from the trays, a micrometer fixture was 
installed in the GA hot cell to measure the diameters of selected trays at 0 and 90 deg orientations. Table 5-2 and Fig. 5-10 present the data as a function of fast fluence and position in the capsule.

The dimensional changes of trays in the top and bottom of the capsule differed as noted in Fig. 5-10. Trays at similar fluence locations exhibited significantly different dimensional changes, suggesting that another factor besides fast fluence affected the growth of the graphite. From the thermal analysis results (Section 4) temperature differences were probably the cause. Section 6.4 analyzes these results.

\subsection{PARTICLE TRAY AUTORADIOGRAPHY}

All the graphite disks that contained GA fuel particles were autoradiographed after irradiation to detect particle types that may have released fission products during the test. The procedure involved placing the empty graphite trays between two standard Polaroid film packs long enough to expose the film. Polaroid type 52 land film at ASA 400 (27 DIN) with a 15 to $20 \mathrm{~s}$ development time was used. The average activity leve1 of the graphite trays was $\sim 160 \mathrm{mR} / \mathrm{h}$ [gamma at $5.08 \mathrm{~cm}$ (2 in.)], requiring a $10 \mathrm{~min}$ exposure. One set of trays had an activity level of only $35 \mathrm{mR} / \mathrm{h}$ [gamma at 5.08 $\mathrm{cm}$ ( 2 in.)], requiring a 30 min exposure. The film packs were placed directly above and below the graphite trays, with only the thickness of the protective film wrap separating the trays from the film. Because of the low activity, this work was performed out of the hot cell in a shielded laboratory hood.

Figures 5-11 and 5-12 are typical autoradiographs of particle trays from four holders. (The aluminum holders were shipping trays used to transport the loaded particle disks from ORNL to GA after the capsule 
disassemb1y.) Since most holders had contained 12 particle trays, the autoradiographs were done in groups of 12 trays for convenience. Several features are readily apparent in these pictures:

1. Almost all trays exhibited distinct areas of activity at the surface of the inner tray circumference.

2. Some trays showed a mottled, random activity over their entire surface.

3. Several trays showed distinct patterns of activity that exactly matched the loading patterns of the fuel particles in the tray holes.

The distinct, bright spots of activity at the tray inner circumferences are most apparent in the top photos of Figs. 5-11 and 5-12. These patterns correlate exactly with the placement of the thermocouples in the experiment and are believed to have been caused by contact with the stainless steel thermocouple sheaths which became activated during the irradiation. Gamma scan results of the particle trays (Section 5.7.2) also indicated the presence of stainless steel. The thermocouples penetrated the experiment from the top and lay in grooves machined into the subassembly center spines. Therefore, trays at the top of the capsule (as in holder 3) show more of these bright spots than trays which were tested at the middle (holder 8) or bottom (holder 14) of the capsule where there were fewer thermocouples. The intensity of these spots also matches the reactor flux profile (i.e., spots on trays tested near the reactor midplane are brighter than those on trays at the ends of the capsule).

The mottled, irregular patterns of activity seen on some trays (those in holder 6, Fig. 5-11 are typical) were the result of accidents that occurred during capsule disassembly or shipment of the trays and particles afterward. In the case of holder 6 , the lid had come loose during shipment, and particles had shifted and were broken, scattering debris and activity 
over the tray surfaces. Some particles had also been crushed in the trays during disassembly (see Section 5.1), and in those cases, the visual exam with the particles in the trays and the autoradiographs correlated very we11. Often the exact holes in which the particles had been crushed could be identified.

Unlike the first two types of activity, the third type of feature, the distinct image of the particle loadings within the trays, indicated that some particles had apparently released fission products during irradiation. The two autoradiographs in Fig. 5-12 show typical examples of this phenomenon. The levels of activity in the tray holes varied in intensity between different trays; in some cases, all holes that had contained particles did not show activity, but the unmistakable hole pattern was evident.

Table 5-3 summarizes the autoradiographic observations on all trays that showed significant activity and compares them with visual exam results with the particles still in the trays. Section 6 further discusses the results of the tray autoradiography, which were included in the performance assessment of the fuel particles.

\subsection{METALLOGRAPHY}

Postirradiation metallography was performed on 20 different capsule fuel particle specimens to evaluate irradiation-induced changes in the particle coatings and kernels. Each specimen was prepared in-cel1 by mounting -20 particles per sample in a thermosetting resin. Following grinding to near the particle midplanes, the mounts were reimpregnated with mounting compound to reduce kernel pullout during the final polishing. The metallography results are presented in two groups: (1) particles with generic TRISO coatings and (2) results on advanced coatings with $\mathrm{ZrC}$ and silicon-alloyed pyrolytic carbon (PyC). 
5.5.1. TRISO-Coated $\mathrm{UC}_{2}, \mathrm{UC}_{\mathrm{x}} \mathrm{O}_{\mathrm{y}},(\mathrm{Th}, \mathrm{U}) \mathrm{O}_{2}$, and $\mathrm{ThO}_{2}$ Particle Types

One relatively high and one low exposure sample of almost every particle type were examined during metallography. Only one sample of TRISO $\mathrm{ThO}_{2}$ was examined; however, this particle type has been extensively characterized in numerous irradiation tests (Ref. 4). Figure 5-13 shows typical kernel microstructures of the TRISO $\mathrm{ThO}_{2}$ particles examined. Figure 5-13 shows an evenly distributed porosity throughout the kernels (compare with preirradiation photo, $\mathrm{Fig} \cdot 2-9$ ). Although one $\mathrm{ThO}_{2}$ kernel (not shown) showed slight, internal cracking, this sample showed no other unusual or detrimental features.

The structure of the $1: 1$ (Th,U) $\mathrm{O}_{2}$ kernels (Fig. 5-14) appeared similar to $\mathrm{ThO}_{2}$, except that the higher exposure sample exhibited much greater porosity, as expected. Also, in the high burnup sample, small white phase pockets that are most likely fission products were evenly dispersed throughout the kernels. In some cases, white phases were concentrated at the kernel-buffer interface; however, these have not been identified as a buildup of fission products.

The kernels of the $\mathrm{UC}_{2}$ and $\mathrm{UC}_{\mathrm{X}} \mathrm{O}_{\mathrm{y}}$ particles also appeared very similar after irradiation. In all cases, the kernels showed evidence of considerable gas evolution, with the size and quantity of gas bubbles proportional to the level of exposure. Figures 5-15 through 5-18 show typical examples of $\mathrm{UC}_{2}, \mathrm{UC}_{0.70_{0}}, \mathrm{UC}_{0.50_{1}} \mathrm{O}_{1}$, and $\mathrm{UC}_{0.20_{1}}$.6 kernel cross sections, respectively. While the $\mathrm{UC}_{2}$ kernels were uniform in structure, the $\mathrm{UC}_{\mathrm{x}} \mathrm{O}_{\mathrm{y}}$ showed a phase segregation in most instances of white and grey areas. This was also evident before irradiation and is typical of $\mathrm{UC}_{\mathrm{X}} \mathrm{O}_{\mathrm{y}}$ kernels fabricated by the ge1-supported precipitate (GSP) process. The predominant phases usually include $\mathrm{UO}_{2}, \mathrm{UC}_{2}$, and $\mathrm{UCO}$, depending on the relative amounts of carbon and oxygen present (Ref. 5). Figure 5-16 shows the varied size and distribution of gas bubbles within the same kerne1. The $\mathrm{UC}_{2}$ and $\mathrm{UC}_{\mathrm{X}} \mathrm{O}_{\mathrm{y}}$ particles also exhibited plastic deformation of the kernels into voids and cracks in the 
buffer. Figure 5-19 shows this effect, which has also been seen in previous accelerated irradiation tests of $\mathrm{UC}_{2}$ at irradiation temperatures comparable to $\mathrm{HRB}-15 \mathrm{~B}$ (Ref. 6).

Al1 the metallographically observed particle types exhibited a ring of densified buffer material around the kernels caused by fission recoils. Figure 5-20 shows an example of this in an $\mathrm{UC}_{0.2} \mathrm{O}_{1.6}$ TRISO particle in which the kernel was lost during polishing.

The buffer layers in many examined TRISO particles showed irradiationinduced shrinkage, particularly the higher exposure samples. This shrinkage was evidenced by the buffer separating from the inner pyrolytic carbon (IPyC) coating (Figs. 5-13, 5-14, and 5-17) and actual cracking and separation within the buffer layer itself (Fig. 5-19).

While polarized light photos of most samples showed moderate optical anisotropy in the PyC coatings which had not been observed before irradiation, these particles showed no IPyC or OPyC coating failures. Figure 5-21 shows some coating cracks that are believed to have occurred during mount preparation because of their orientation and because the visual examination detected no OPyC cracking.

Some SiC layer cracking was observed during metallography of the HRB$15 \mathrm{~B}$ particles; however, this was not extensive, and as with the PyC coating cracks mentioned above, the orientation and appearance caused suspicion of damage during mount preparation. The $\mathrm{UC}_{\mathrm{X}} \mathrm{O}_{\mathrm{y}}$ particles exhibited more of this Sic cracking, but these were not the only particles in which cracking was observed. The SiC layer showed three features however, which could potentially degrade structural performance; these were flaws within the coating and two types of porosity. Figure 5-22 shows examples of the short, lenticular flaws observed in some of the HRB-15B particles. Flaws of this type have been observed before and may be involved in the formation of free silicon areas (Ref. 7) within the SiC. One type of SiC porosity was most prevalent in the $\mathrm{ThO}_{2}$ and $1: 1(\mathrm{Th}, \mathrm{U}) \mathrm{O}_{2}$ samples and was confined to the inner half 
of the coating layer, as shown in Fig. 5-23. In some cases, this resembled corrosive attack of the SiC; in other cases, it appeared to be only tiny voids within the layer. This feature was not apparent prior to irradiation. The other type of porosity observed in $\mathrm{HRB}-15 \mathrm{~B}$ particles was found almost exclusively in the $\mathrm{SiC}$ layers of TRISO $\mathrm{UC}_{\mathrm{x}} \mathrm{O} y$ particles. This porosity, shown in Fig. 5-24(a), was randomly dispersed throughout the entire layer. More than one of the mounts was repolished, but in each case the porosity remained. An examination of unirradiated particles from the same batches, however, also showed this evenly dispersed porosity [Fig. 5-24(b)], indicating that it was not irradiation damage.

Table 5-4 summarizes the metallographic examinations on the TRISO-coated particles discussed in this section.

\subsection{2. $\mathrm{UO}_{2}$ and UO 2 TRISO Plus Silicon-Alloyed BISO Particle Types}

Capsule HRB-15B tested an advanced fuel type, the UO ${ }_{2}^{*}$ kernel. Oxygen is released when an oxide kernel fissions, building a gas pressure inside the particle and apparently also enhancing kernel amoeba migration. However, oxygen can be gettered by $\mathrm{ZrC}$ at HTGR operating temperatures through the following reactions:

$$
\begin{gathered}
\mathrm{O}_{2}+\mathrm{ZrC}+\mathrm{ZrO}_{2}+\mathrm{C}, \\
2 \mathrm{CO}+\mathrm{ZrC} \rightarrow \mathrm{ZrO}_{2}+3 \mathrm{C},
\end{gathered}
$$

according to whether the free oxygen reacts with $\mathrm{ZrC}$ directly or first reacts with carbon coatings, then with $\mathrm{ZrC}$. The net effect of the $\mathrm{ZrC}$ is to buffer the oxygen potential at the $\mathrm{ZrC} / \mathrm{ZrO}_{2}$ equilibrium.

Oxide fuel kernels have performance advantages over carbide kernels in relation to hydrolysis of failed fuel and migration of rare-earth fission products. Therefore, oxide fuels offer potential performance improvement if amoeba migration and the buildup of gas pressure can be controlled by adding 
ZrC. Two different methods of incorporating $\mathrm{ZrC}$ into fuel particles were tested in HRB-15B: (1) a solid layer of $\mathrm{ZrC}$ was deposited over the kernel, as shown in Fig. 5-25, and (2) ZrC was dispersed throughout the buffer layer in a codeposition process, as shown in Fig. 5-26. In both cases, a 10- $\mu \mathrm{m}$ seal coat of dense PyC was applied directly to the kernel before the $\mathrm{ZrC}$ was deposited to protect the kernel from possible chemical reactions. The solid layer of $\mathrm{ZrC}$ was tested at nominal thicknesses of 5 and $10 \mu \mathrm{m}$, whereas the batch with $\mathrm{ZrC}$ dispersed in the buffer had an amount of $\mathrm{ZrC}$ equivalent to that of a solid 5- $\mu \mathrm{m}$ layer. In all cases, more than enough zirconium was present to react with all of the oxygen released through fissions in the $\mathrm{UO}_{2}$ kerne1s.

Figures 5-25 and 5-26 show that a new phase has formed in irraliated particle kernels with $\mathrm{ZrC}$ getters. Electron microprobe techniques examined these features for chemical composition, as illustrated in Fig. 5-27, and the features were found to consist largely of carbon. A small amount of cesium was also distributed throughout the features in about the same concentration as in the buffer PyC. The features did not contain appreciable amounts of uranium, cerium, palladium, ruthenium, neodymium, praseodymium, or molybdenum, which were all rather uniformly distributed throughout the remainder of the kernel, nor did they contain zirconium, which was found only outside the kernel where it had been originally deposited.

The only detrimental irradiation effect observed in $\mathrm{UO}_{2}^{*}$ particles concerned occasional cracking of the porous inner buffer layer of the particles, as shown in Fig. 5-28. Perhaps kernel expansion, resulting from formation of the large carbon phases, contributes to this buffer cracking. In addition, the shrinkage of the inner buffer layer caused by short-range fission recoils seems to be less in $\mathrm{UO}_{2}^{*}$ particles than in $\mathrm{UO}_{2}$ particles, where a much more distinct densified inner buffer layer has left a gap between the kernel and buffer (Fig. 5-29). This type of buffer damage was restricted to $\mathrm{UO}_{2}^{*}$ particles, however, as illustrated by the cracked buffer layers in Fig. 5-19. 
Also, a large number of silicon-alloyed BISO particles are in capsule $\mathrm{HRB}-15 \mathrm{~B}$, including nine different batches of LEU fissile particles and two batches of $\mathrm{ThO}_{2}$ fertile particles (Table 2-1). No irradiation-induced failures of structural coatings were observed for any of these particles, but autoradiography of the graphite trays in which the particles were irradiated (Section 5.4) suggests that some leakage of fission products occurred through intact silicon-BISO coatings. This will be investigated in more detail in out-of-pile thermal annealing experiments on irradiated particles. The nine batches of JEU fissile particles with silicon-alloyed BISO coatings had an $\sim 40-\mu m-t h i c k$ inner ring of pure PyC in their outer coatings. This was followed with the deposition of an $120-\mu \mathrm{m}$-thick alloyed layer. The larger irradiaton-induced shrinkage of the pure IPyC ring in relation to the alloyed outer portion of the coating sometimes caused delamination cracks to open up between these coating components, as shown in Fig. 5-30.

Clear demarcation lines were seen within the alloyed portion of the coating itself, in many cases. These lines at first appeared to be delaminations; however, higher magnification examinations showed them to be bands of higher porosity within the coating (Fig. 5-31) and not separations. The only other irradiation damage observed in silicon-alloyed BISO particles was buffer damage in ZrC-gettered particles (Fig. 5-32), the same as had been observed for TRISO particles (i.e., buffer cracking in particles with solid $\operatorname{ZrC}$ layers and selective erosion of buffer layers containing dispersed $\mathrm{ZrC}$ to produce a characteristic flower-petal design).

\subsection{ELECTRON MICROPROBE}

ORNL performed electron microprobe analysis on metallographic mounts of four particle types irradiated in $\mathrm{HRB}-15 \mathrm{~B}$ : (1) TRISO-coated $\mathrm{UC}_{0.2} \mathrm{O}_{1.6}$ (tray 84), (2) TRISO $\mathrm{UC}_{2}$ (tray 90), (3) TRISO $\mathrm{UO}_{2}$ with $\mathrm{ZrC}$ layer (tray 98), and (4) silicon-BISO-coated $\mathrm{UO}_{2}$ with $\mathrm{ZrC}$ layer (tray 28). Figure 5-27 shows microprobe results on a particle from tray 28 . In all cases, the heavy metals (U,Pu) remained within the kernel. Similarly, the volatile and nonvolatile fission product metals identified either remained within the kernel 
(Fig. 5-33) or concentrated at the kerne1-buffer interface (Fig. 5-34). During metallography, most particles showed a ring of densified buffer material, which may account for the buildup of some fission product metals at this location. This microprobe showed no fission product buildup at the IPYC or SiC layers. Since the three TRISO-coated samples analyzed were all at peak exposure positions in the capsule, the relatively low irradiation temperature of $-900^{\circ} \mathrm{C}$ was considered to be the main reason for fission products not moving within these particles.

5.7. GAMMA ANALYSIS

\subsubsection{Irradiated Microsphere Gamma Analysis}

The ORNL Irradiated Microsphere Gamma Analyzer (IMGA) characterized unbonded particles from 11 particle batches irradiated in capsule HRB-15B, as shown in Table 5-5. In addition, the particles characterized with the ORNL postirradiation gas analyzer (PGA) and 1isted in Table 5-7 were also gamma-counted with the IMGA. This completely automated device separately gamma-scanned particles from each batch; fission product activity ratios were then calculated from the data to indicate coating integrity in the particles. The fission product activity ratios that existed in the particles at the end of the irradiation were back-calculated from the IMGA-measured inventories using the known isotopic disintegration rates. Appendix $C$ separately details the IMGA analysis, and Section 6 discusses the results. In summary, the analysis indicated no cesium loss from the particles, but detected an unquantified amount of silver release.

\subsubsection{Gamma Scan of Empty Particle Trays}

A germanium-lithium detector gamma scanned selected particle trays (after the irradiated particles had been removed) to determine the type and quantities of nuclides present. These data were useful for correlating with autoradiography, IMGA, and other PIEs in characterizing the complete irradiation performance of the fuel particles. Twelve empty particle trays were 
scanned separately, including ones that had shown significant activity on the autoradiograph and ones that had not. All the trays scanned had small amounts of scandium, chromium, cobalt, and in some cases, manganese, as a result of the activation of the stainless-steel thermocouple sheaths which were adjacent to the inner circumferences of al1 trays. This activity was also apparent on the tray autoradiographs.

Fission product nuclides were also detected on most of the trays scanned. Specifically, Cs-134, Cs-137, and $\mathrm{Ag}-110 \mathrm{~m}$ were detected in varying amounts, as detailed in Table 5-6. The scanning was done over an energy range of 1 to $2048 \mathrm{keV}$. Detector live times averaged 13.16 min for one group of trays that was counted for 15 min and 4.84 min for another group that was counted for, $5 \mathrm{~min}$. The major peaks employed and the average counting errors for each were

Major Peaks (keV) Av Counting Errors (\%)

$\begin{array}{lcr}\mathrm{Ag}-110 \mathrm{~m} & 1384.7 & <18 \\ \mathrm{Cs}-134 & 796 & <9 \\ \mathrm{Cs}-137 & 661.7 & <5\end{array}$

In some cases, as noted in Table 5-6, the counting errors exceed those given here, because the activities were very small and the count rate was proportionately lower. The percent release values were calculated by dividing the fission products measured on the trays by the fission products calculated for each tray (see Sections 6.1 through 6.3 ). The nuclide inventories were calculated using data generated with the CURIE code. This code was run for the selected tray positions in $A R B-15 B$ as part of the burnup analysis (see Section 4.2). Appendix D discusses the errors associated with the tray gamma scans.

\subsection{POSTIRRADIATION GAS ANALYSIS}

The ORNL PGA measured the postirradiation gas content of particles from 11 TRISO-coated capsule batches tested in HRB-15B. Comparing selected 
fission gases released from each particle upon crushing to the IMGAcalculated theoretical inventory gave the particle gas retentiveness. Three essentially stable isotopes of krypton ( $\mathrm{Kr}-83, \mathrm{Kr}-89$, and $\mathrm{Kr}-86$ ) and four of xenon (Xe-131, Xe-132, Xe-134, and Xe-136) were collected following a separate and complete crushing of each particle at room temperature. A timeof-flight mass spectrometer quantified the different gas species present in five particles from each of the 11 batches. Reference 8 gives more complete details on the PGA and its operation.

Table 5-7 presents results on the average nmoles of krypton and xenon collected per particle for each particle batch. The theoretical inventories of the particles were also calculated, based on the mean kernel loading of each batch and the kernel burnup. Table 5-7 gives the ratios of the measured and theoretical gas contents, showing that these particles retained high percentages of fission gases. The ratios ranged from $72 \%$ to $111 \%$ with no trends evident among the different kerne1 types. In qualifying these data, a typical standard deviation of $15 \mu \mathrm{m}$ on a $350-\mu \mathrm{m}$ kernel could account for a $12 \%$ variation in the theoretical inventories. Also, the measured inventories had $1 \sigma$ variations as high as $13 \%$ for krypton and $14 \%$ for xenon, explaining how some values exceed 100\%. Thus, measured/theoretical ratios of the magnitude obtained here are not unreasonable.

\subsection{FISSION GAS RELEASE}

Irradiated fuel particles from three capsule samples were reirradiated in the GA TRIGA reactor to determine the postirradiation release-to-birth rate of $\mathrm{Kr}-85 \mathrm{~m}$. TRISO-coated $\mathrm{UC}_{0.7 \mathrm{O}_{0} .5},(\mathrm{Th}, \mathrm{U}) \mathrm{O}_{2}$, and $\mathrm{UC}_{2}$ particles were mixed with graphite flour to simulate fuel rod geometry and irradiated at $1100^{\circ} \mathrm{C}$ in accordance with test procedure $\mathrm{ACD}-140-\mathrm{A}-7$. Each sample had a low release rate only slightly higher than the corresponding preirradiation value, as shown in Table 5-8. These results agree with the PGA data (Section 5.8), which indicated high fractions of fission gases retained in the particles. 


\subsection{OPYC COATING DENSITIES}

Measurements of postirradiation OPyC coating densities were made on seven particle types from capsule $\mathrm{HRB}-15 \mathrm{~B}$. The outer coatings were broken off the substrates remotely, then placed in a liquid gradient column for the density determination. Three of the samples were from TRISO-coated samples with standard OPyCs, and four were silicon-doped OPyCs from silicon-BISO particles. Table 5-9 tabulates the results, and Figs. 5-35 and 5-36 plot them.

Figure 5-35 compares the standard OPyC measured density changes with published data (Ref. 9); these changes are fairly consistent with the published values. The silicon-doped OPyC measurements shown in Fig. 5-36, however, when compared with published values for unrestrained silicon-OPyC density change (Ref. 10), are quite different. Even though the initial densities differ considerably and the silicon-OPyC layers are semirestrained on the fuel particles, the same trend of density increase with fluence would be expected. Because OPyCs are more difficult to separate from BISO particles than from TRISOs and because this work had to be done remotely the samples obtained from the irradiated particles were very possibly unclean with buffer fragments attached. Although not certain, this would explain the apparent density decrease shown in Fig. 5-36. 
-

- 


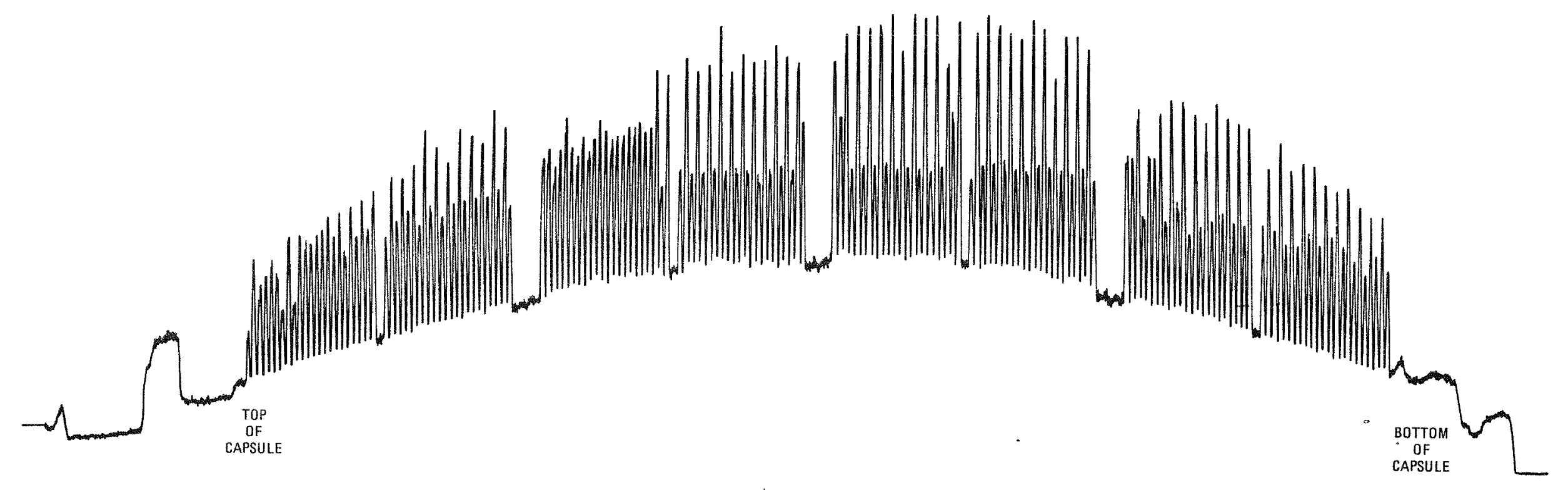

Fig. 5-1. Gamma scan of HRB-15B Gamma scan of HRB-15B
following removal from HFIR 



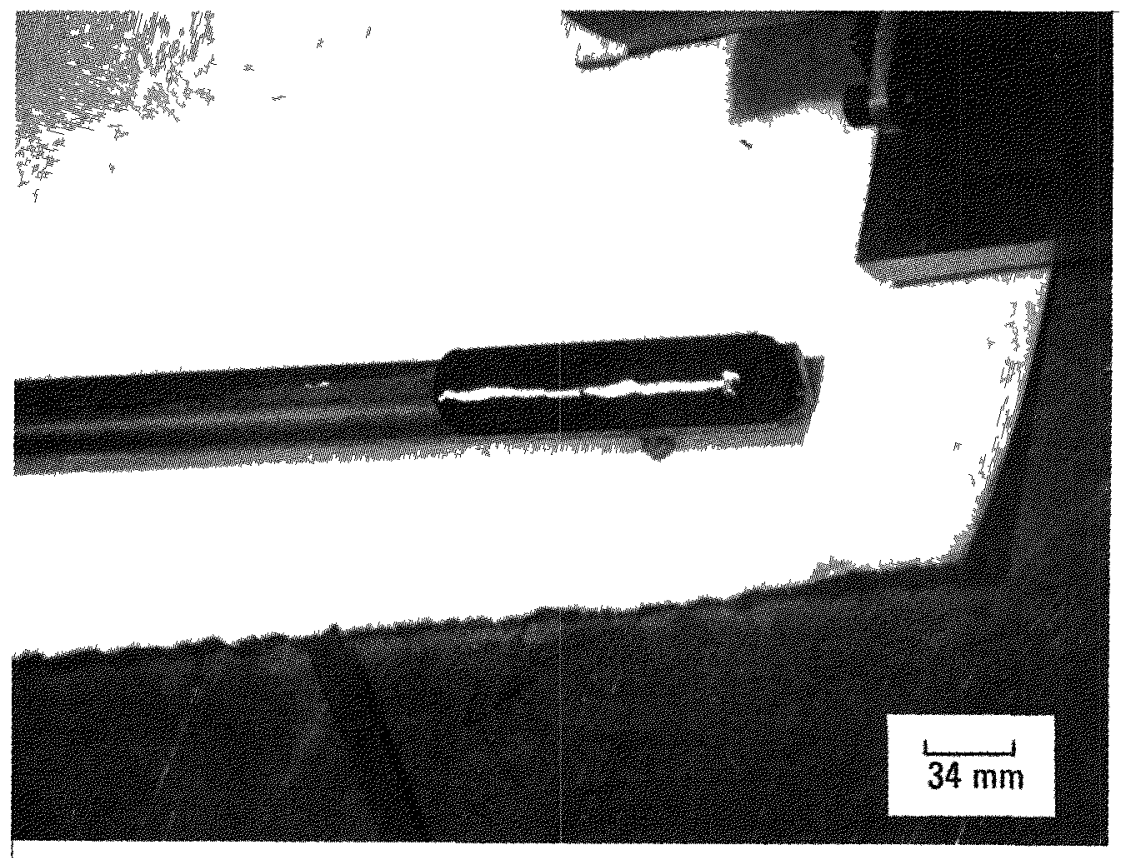

Fig. 5-2. Subassembly 3 after removal from the containment and application of the reference paint stripe 


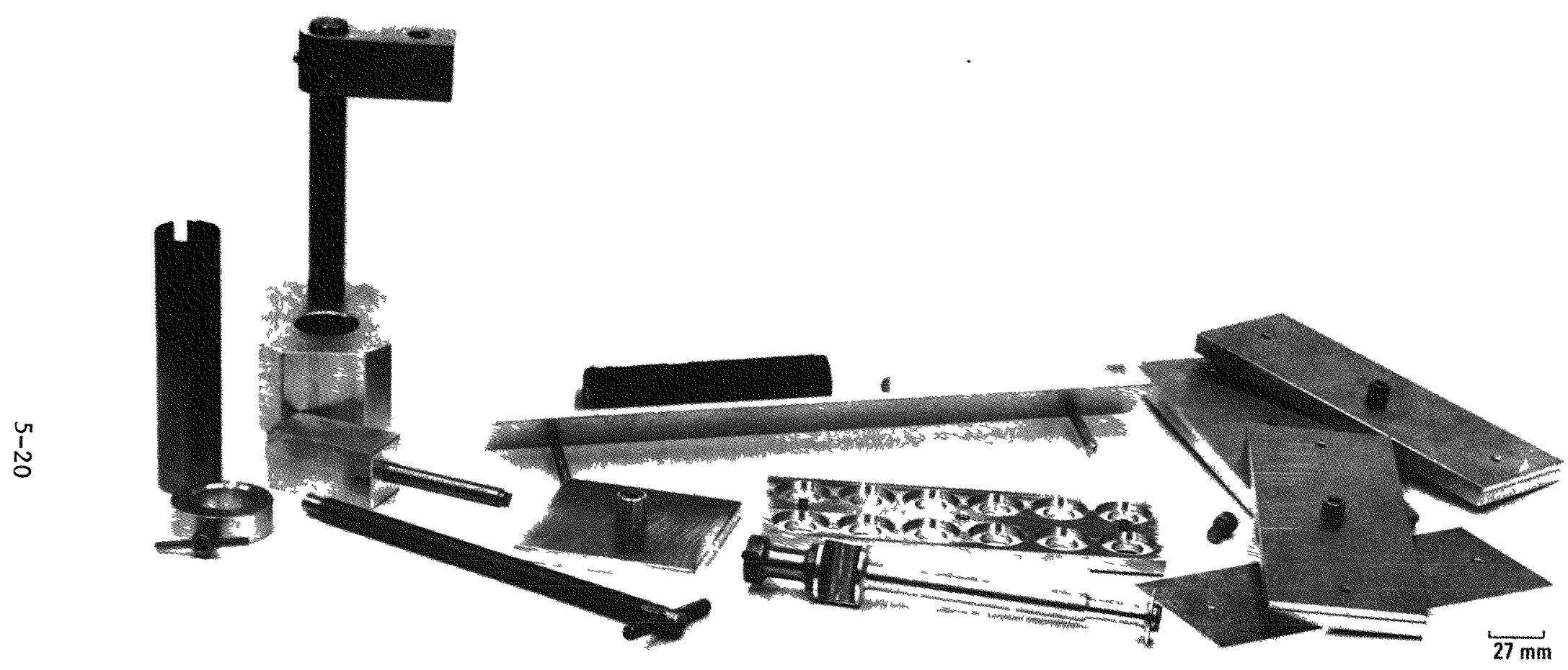

Fig. 5-3. Special tools used to remotely disassemble the HRB-15B subassemblies 


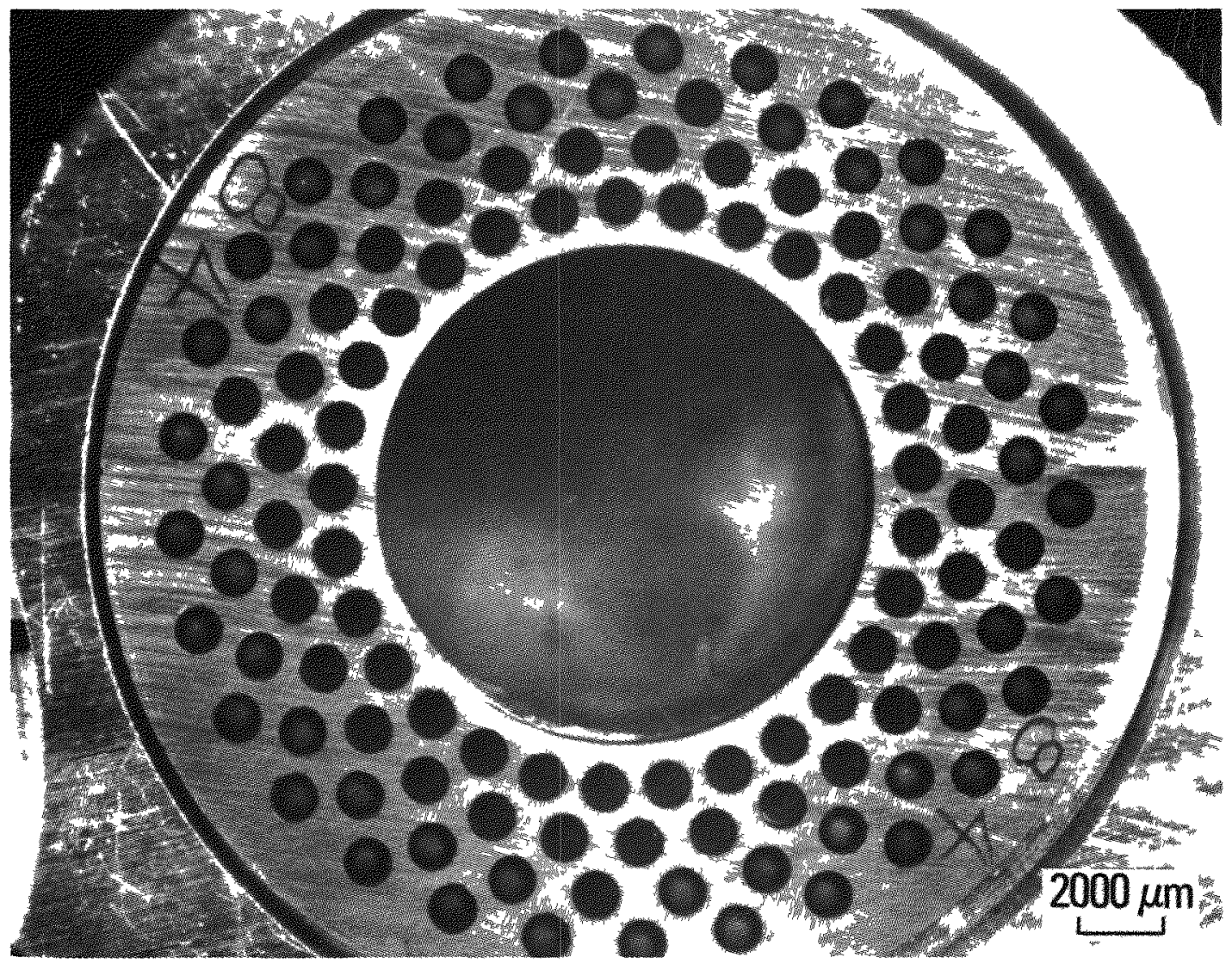

Fig. 5-4. Graphite tray No. 84 with irradiated TRISO UC0.201.6 particles in place: $6.5 \times 10^{25} \mathrm{n} / \mathrm{m}^{2}(\mathrm{E}>29 \mathrm{fJ})$ HTGR fast fluence, $26.5 \%$ FIMA at a time-average maximum particle surface temperature of $905^{\circ} \mathrm{C}$ 

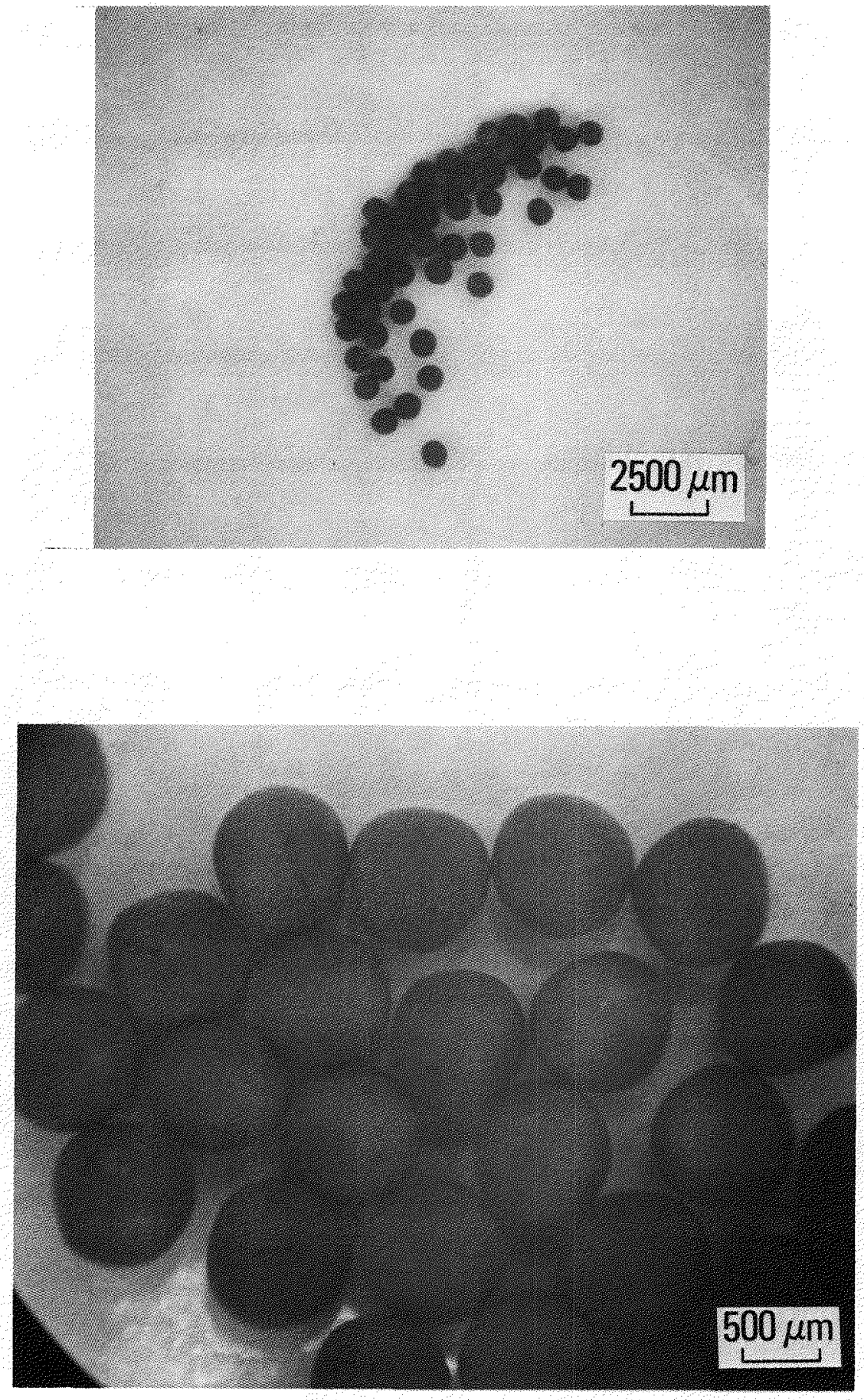

Fig. 5-5. Postirradiation appearance of TRISO UC $0.20_{1} .6$ particles from graphite tray No. 84: $6.5 \times 10^{25} \mathrm{n} / \mathrm{m}^{2}(\mathrm{E}>29 \mathrm{fJ})$ HTGR fast fluence, $26.5 \%$ FIMA at a time-average maximum particle surface temperature of $905^{\circ} \mathrm{C}$ 


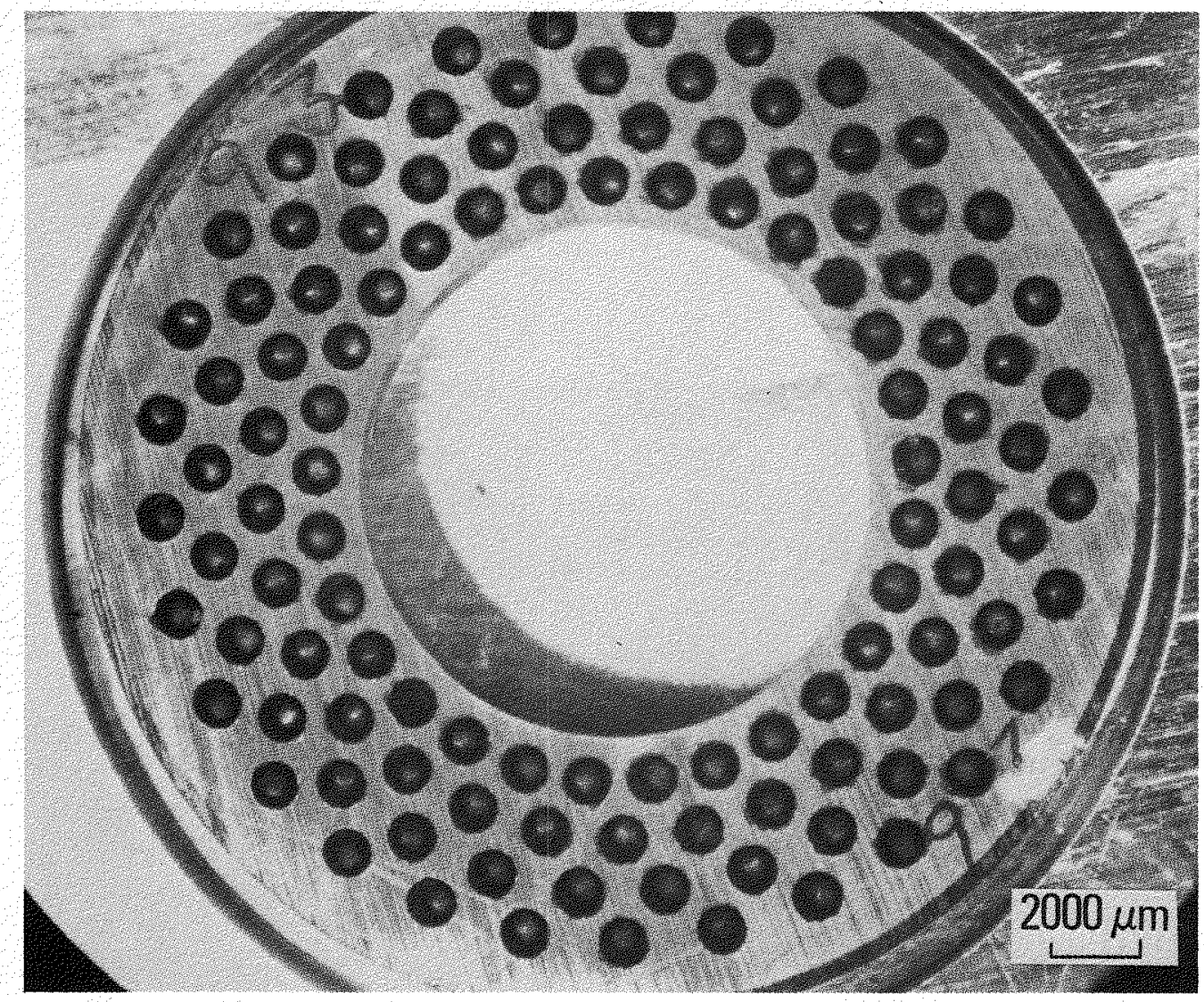

Fig. 5-6. Graphite tray No, 93 with irradiated TRISO ThO 2 particles in place: $6.5 \times 10^{25} \mathrm{n} / \mathrm{m}^{2}(\mathrm{E}>29 \mathrm{fJ})$ HTGR fast fluence, $6.0 \%$ FIMA at a time-average maximum particle surface temperature of $870^{\circ} \mathrm{C}$ 

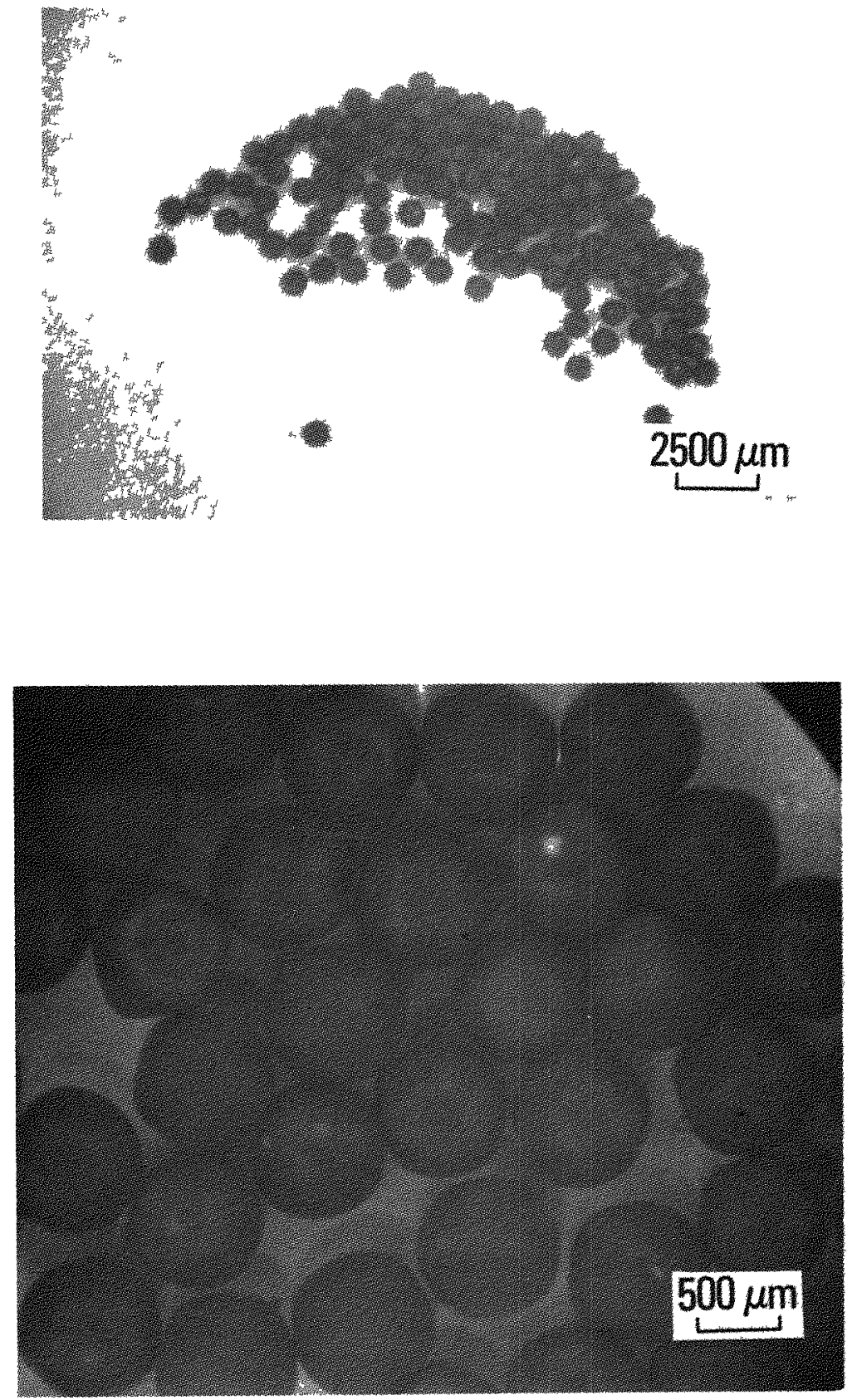

Fig. 5-7. Postirradiation appearance of TRISO $\mathrm{ThO}_{2}$ particles from graphite tray No. 93: $6.5 \times 10^{25} \mathrm{n} / \mathrm{m}^{2}$ ( $\mathrm{E}>29 \mathrm{fJ}$ ) HTGR fast fluence, $6.0 \%$ FIMA at a time-average 'maximum particle surface temperature of $870^{\circ} \mathrm{C}$ 

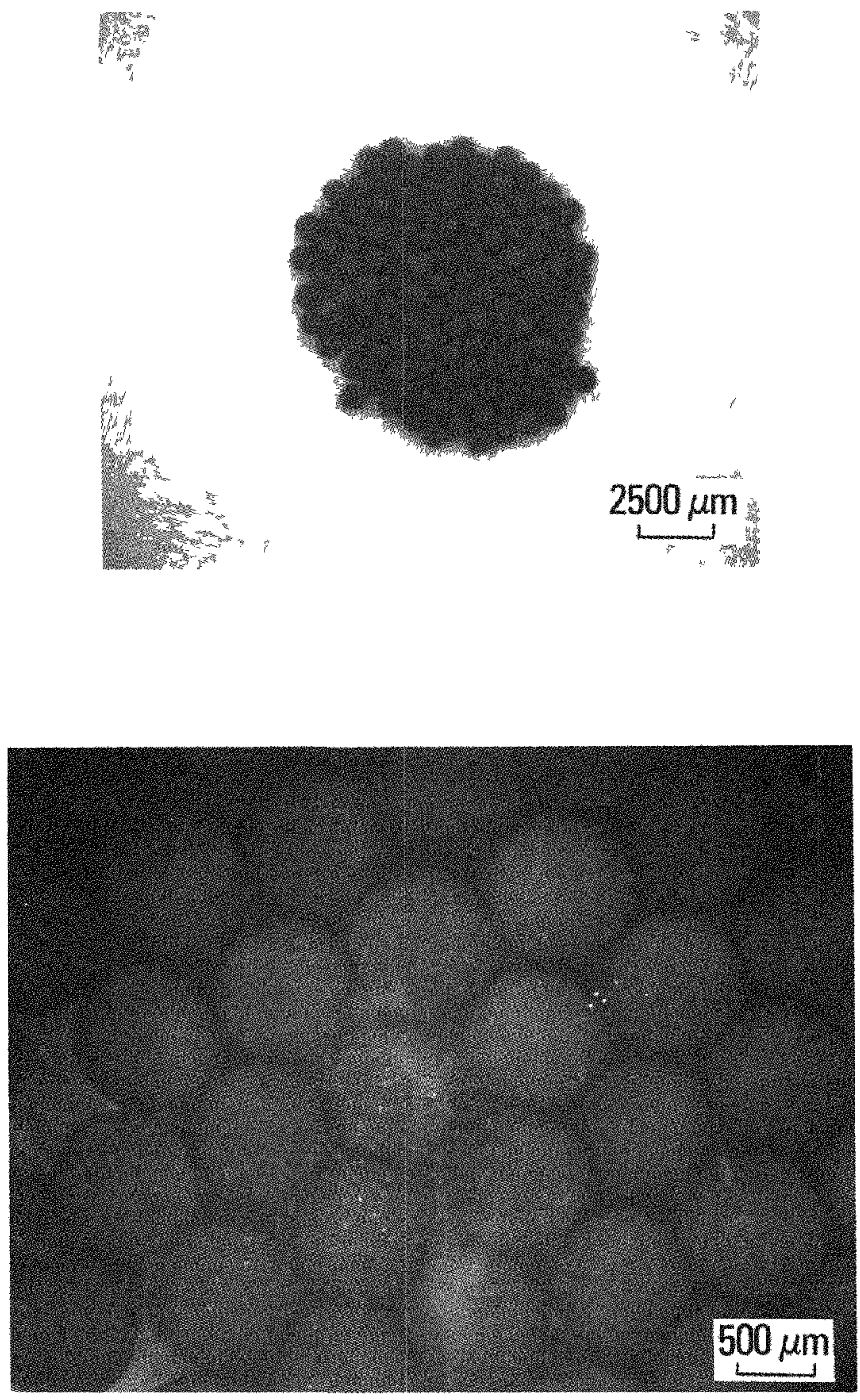

Fig. 5-8. Postirradiation appearance of silicon-BISO (Th, U) $\mathrm{O}_{2}$ particles from tray No. 114: $6.2 \times 10^{25} \mathrm{n} / \mathrm{m}^{2}$ (E $\left.>29 \mathrm{fJ}\right)_{\text {HTGR }}$ fast fluence, $16.2 \%$ FIMA at a time-average maximum particle surface temperature of $895^{\circ} \mathrm{C}$ 

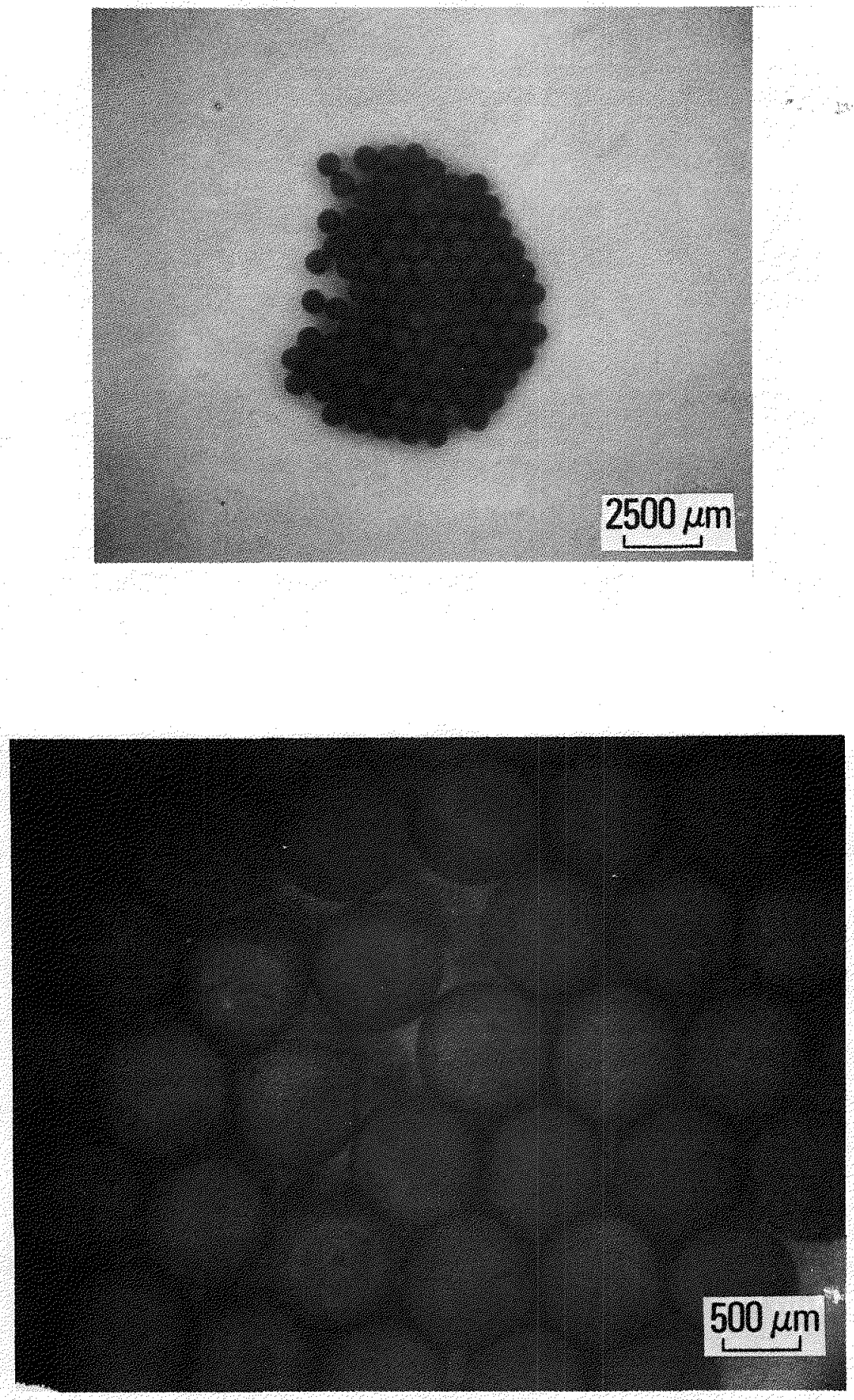

Fig. 5-9. Postirradiation appearance of silicon-BISO UO2 particles from tray No. $118: 6.1 \times 10^{25} \mathrm{n} / \mathrm{m}^{2}$ (E $>29 \mathrm{fJ}$ ) HTGR fast fluence, 26. $3 \%$ FIMA at a time-average maximum particle surface temperature of $915^{\circ} \mathrm{C}$ 


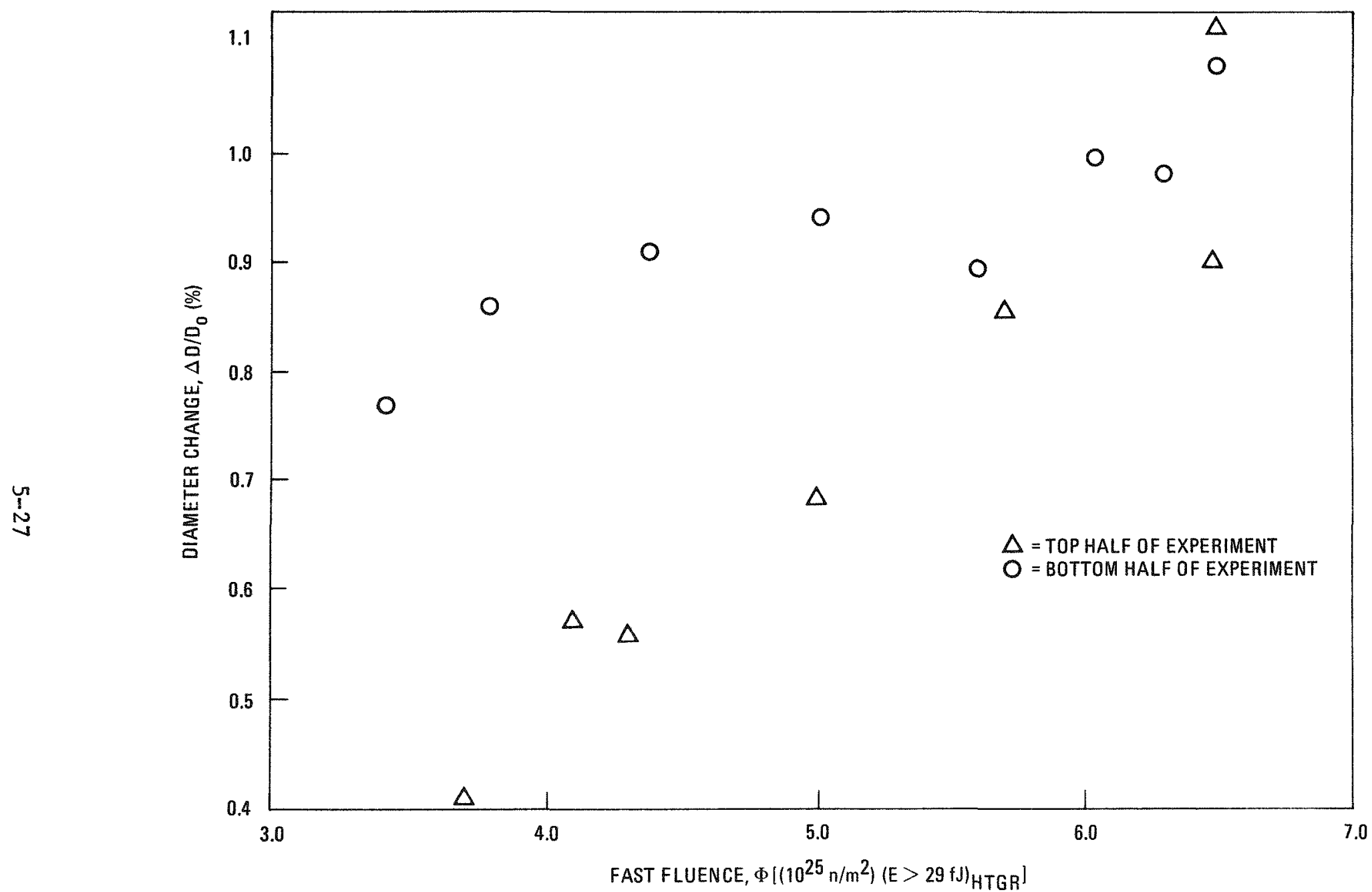

Fig. 5-10. POCO graphite dimensional change in Capsule HRB-15B 


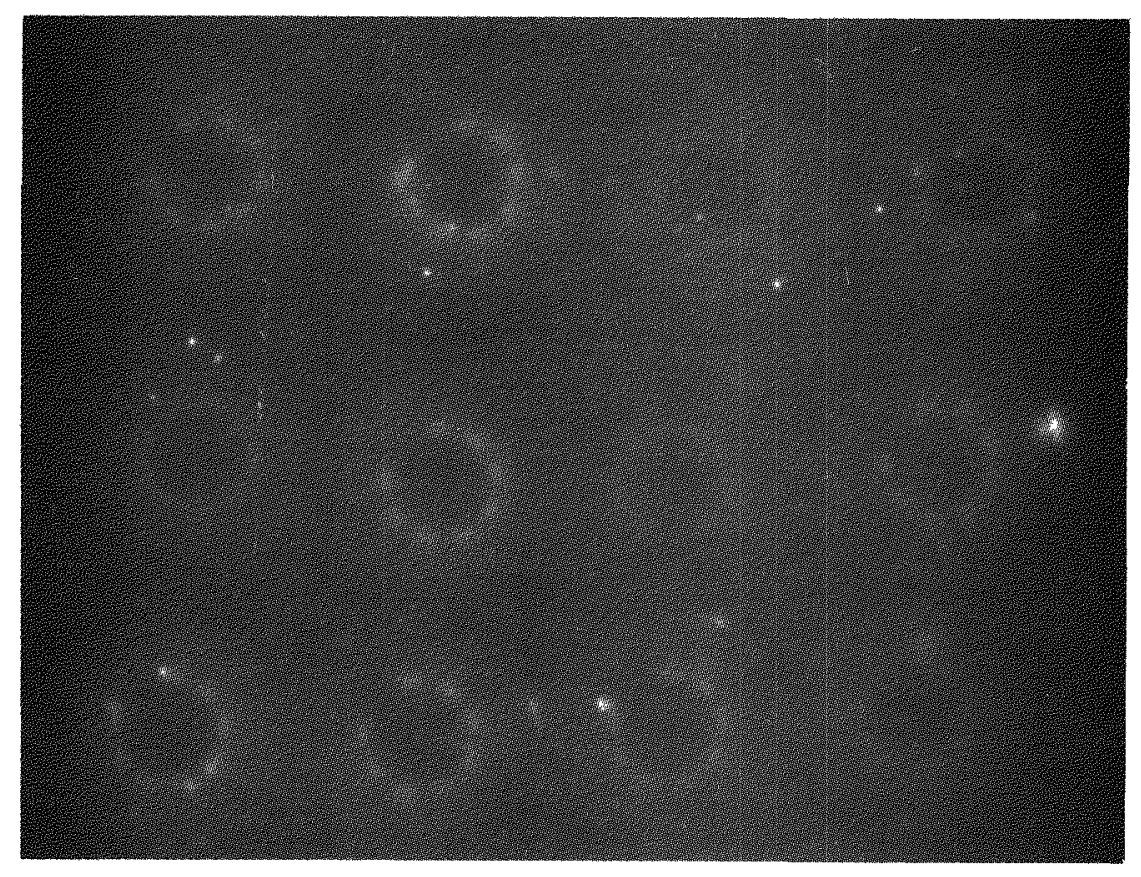

(a)

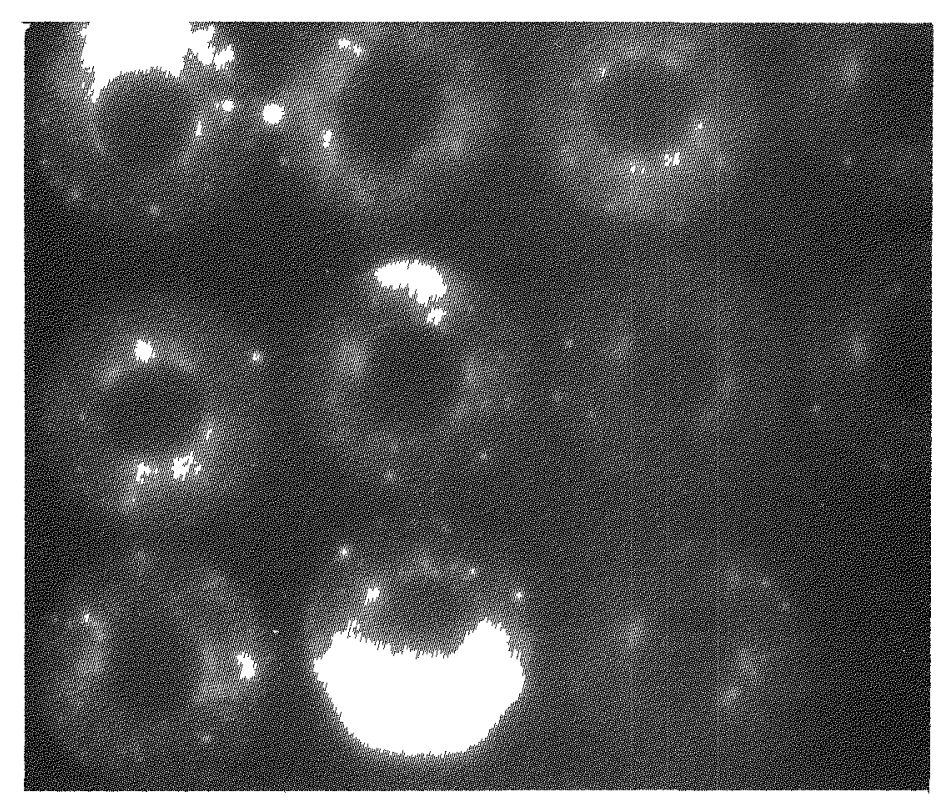

(b)

Fig. 5-11. Autoradiographs of graphite particle trays, holders 3 and 6:

(a) holder $3,4.5$ to $5.2 \times 10^{25} \mathrm{n} / \mathrm{m}^{2}$ (E > $29 \mathrm{fJ}$ ) HTGR fast fluence at a time-average temperature of $800^{\circ} \mathrm{C}$ and (b) holder $6,4.7$ to $6.3 \times 10^{25} \mathrm{n} / \mathrm{m}^{2}$ (E $>29 \mathrm{fJ}$ ) HTGR fast fluence at a time-average temperature of $860^{\circ} \mathrm{C}$. Film exposure time was $10 \mathrm{~min}$. 


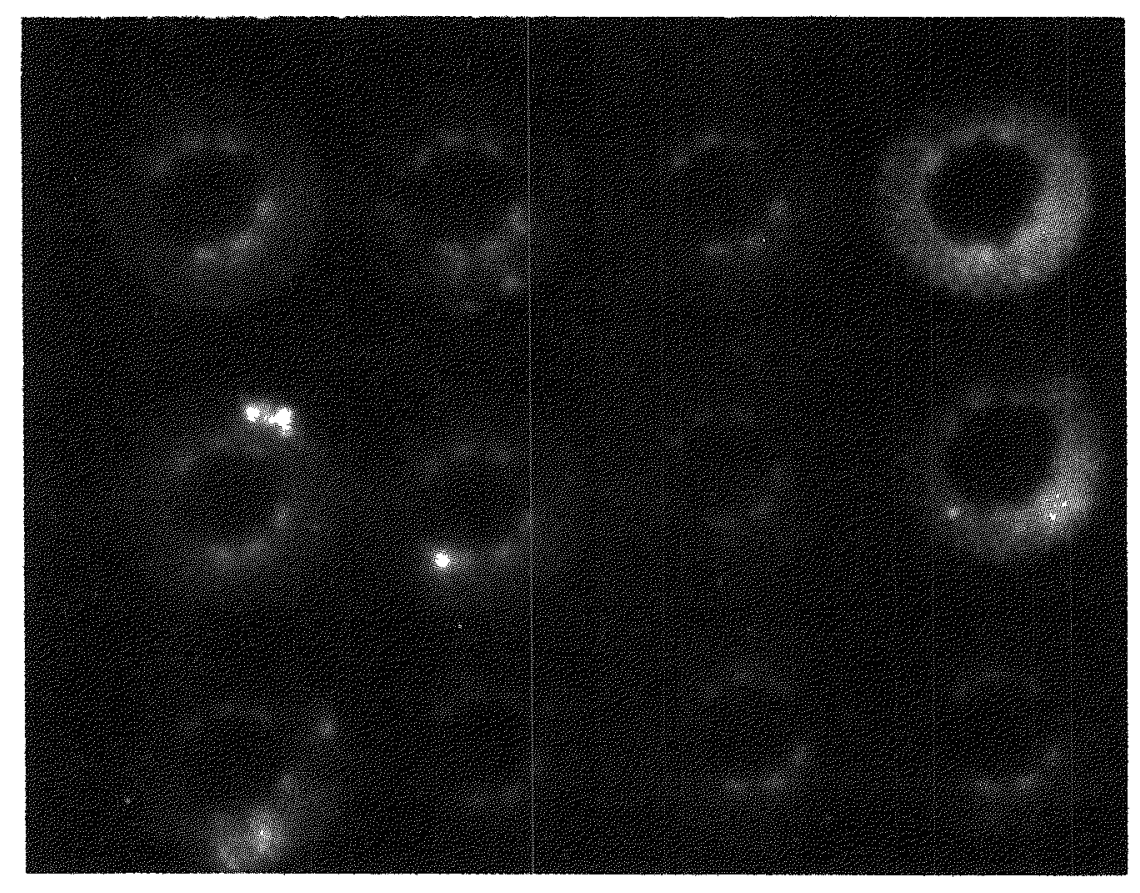

(a)

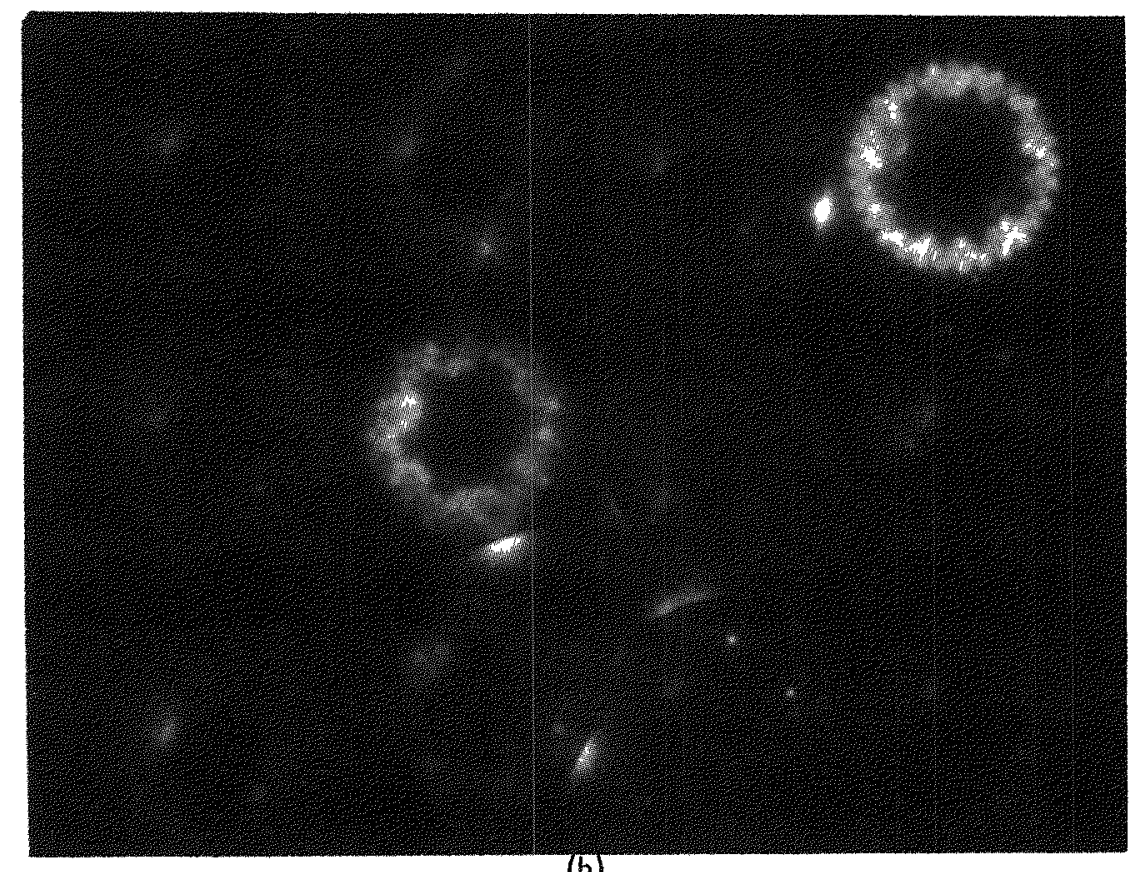

(b)

Fig. 5-12. Autoradiographs of graphite particle trays, holders 8 and 14: (a) holder $8,6.3$ to $6.5 \times 10^{25} \mathrm{n} / \mathrm{m}^{2}$ (E $>29 \mathrm{fJ}$ ) HTGR fast fluence at a time-average temperature of $845^{\circ} \mathrm{C}$ and (b) holder $14,3.7$ to $4.6 \times 10^{25} \mathrm{n} / \mathrm{m}^{2}(\mathrm{E}>29 \mathrm{fJ})$ HTGR fast fluence at a time-average temperature of $855^{\circ} \mathrm{C}$. Exposure time was $10 \mathrm{~min}$. 


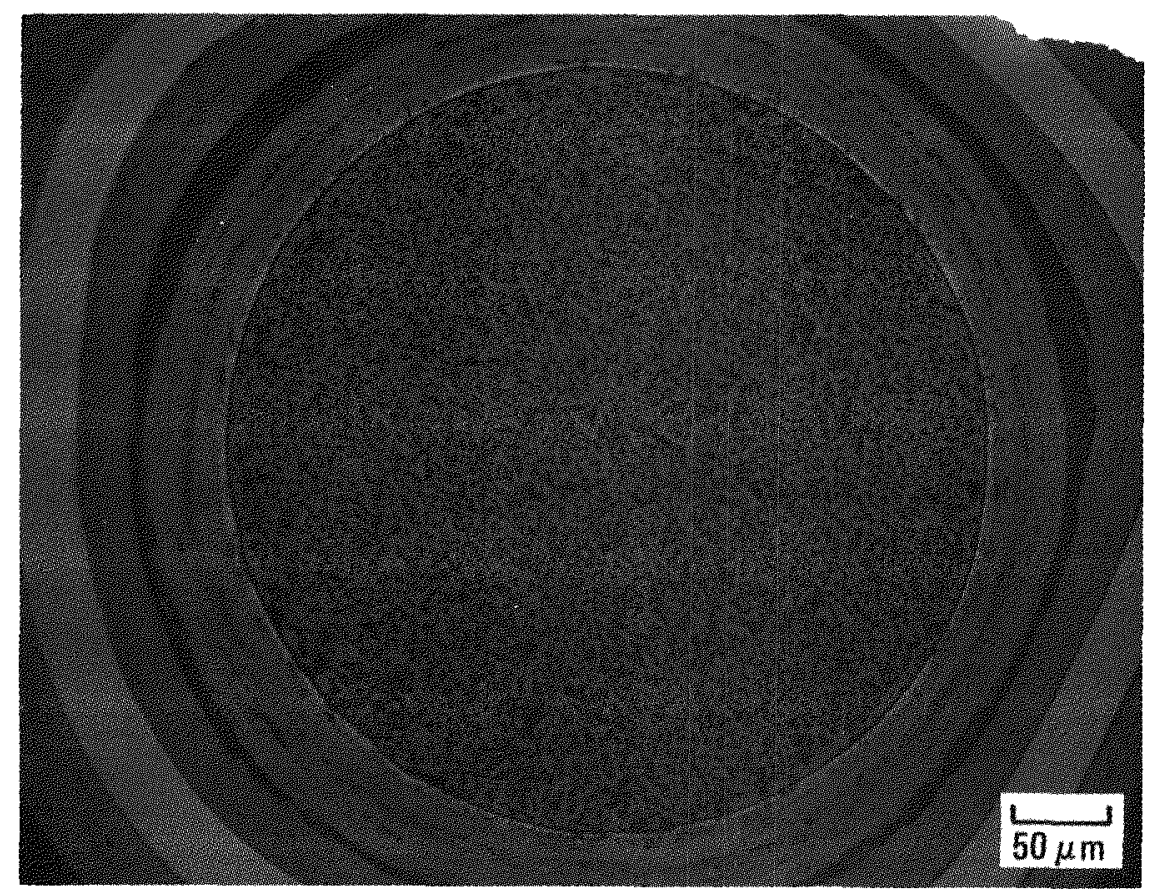

L7927.10

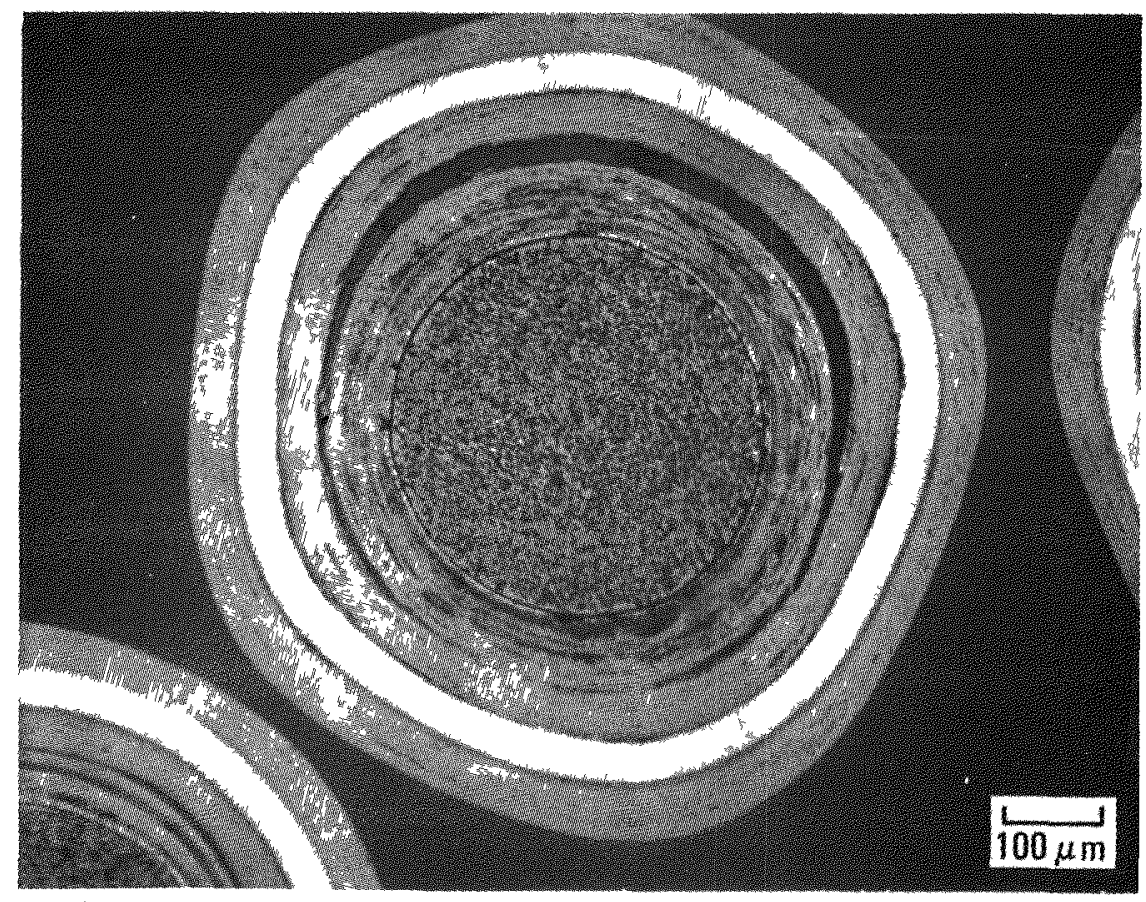

L7927-1

Fig. 5-13. Postirradiation appearance of TRISO $\mathrm{ThO}_{2}$ kernels: (6252-15$0140-3) 6.4 \times 10^{25} \mathrm{n} / \mathrm{m}^{2}(\mathrm{E}>29 \mathrm{fJ})_{\text {HTGR }}$ fast fluence, $5.7 \%$ FIMA and time-average maximum particle surface temperature of $860^{\circ} \mathrm{C}$ 


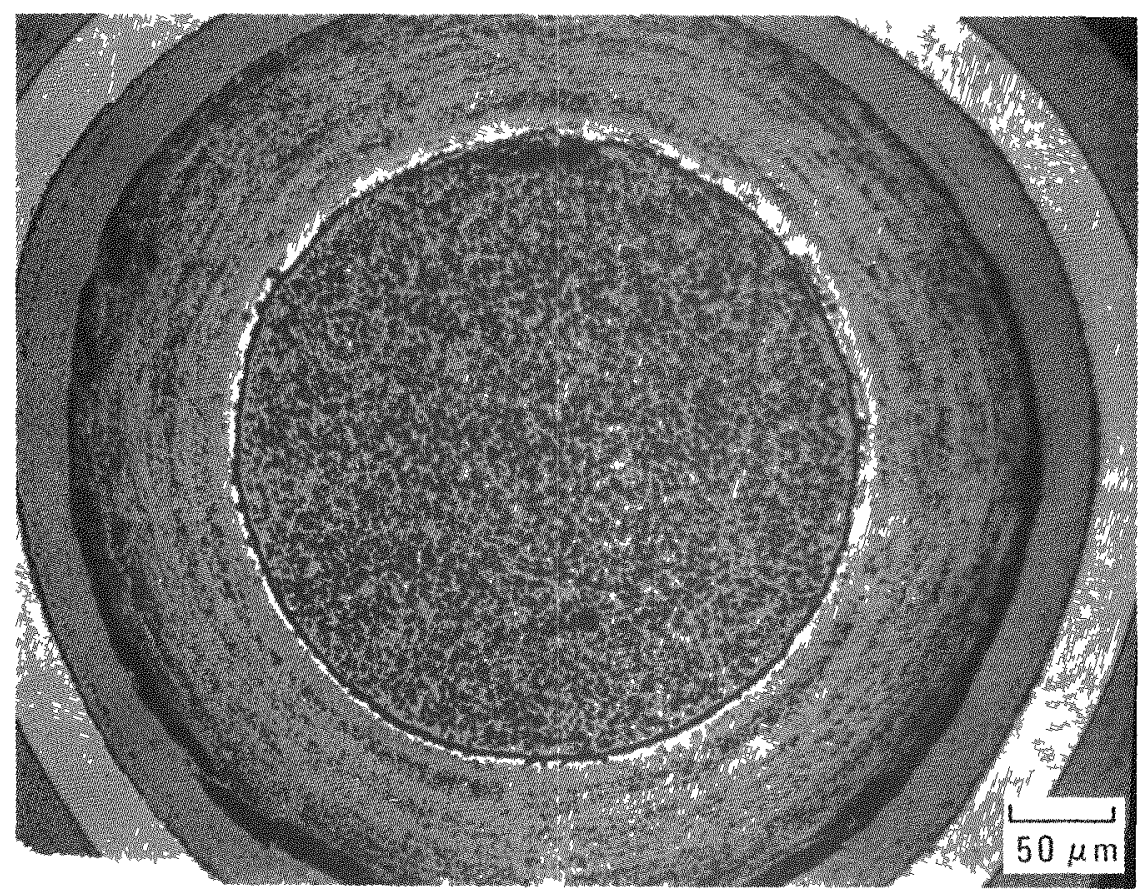

L7927 85

(a)

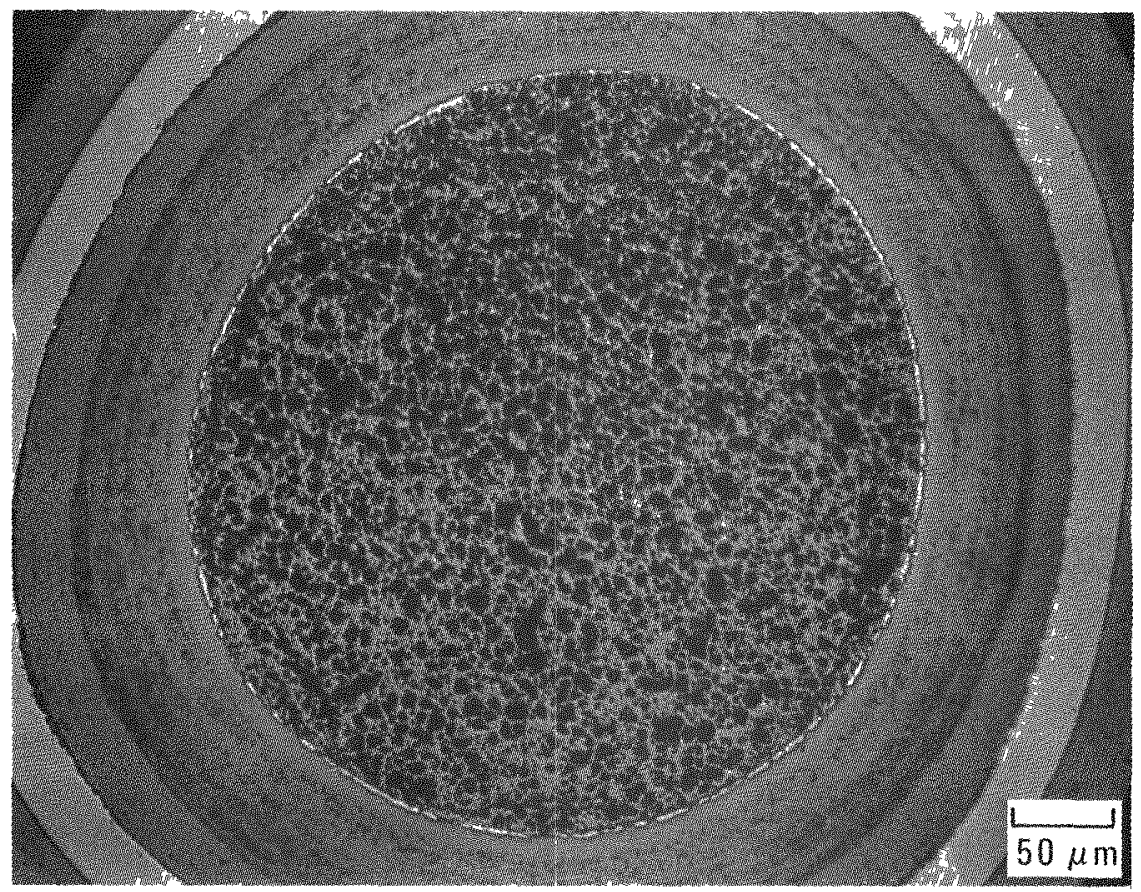

L7927-19

(b)

Fig. 5-14. Postirradiation appearance of $1: 1(\mathrm{Th}, \mathrm{U}) \mathrm{O}_{2}$ TRISO kernels: (a) $(6155-05-0111-1) 3.8 \times 10^{25} \mathrm{n} / \mathrm{m}^{2}(\mathrm{E}>29 \mathrm{fJ})$ HTGR fast fluence, 11.1\% FIMA and time-average maximum particle surface temperature of $840^{\circ} \mathrm{C}$ and (b) $(6155-05-0111-3) 6.6 \times 10^{25} \mathrm{n} / \mathrm{m}^{2}(\mathrm{E}>29 \mathrm{fJ})_{\mathrm{HTGR}}$ fast fluence, $16.4 \%$ FIMA and time-average maximum particle surface temperature of $885^{\circ} \mathrm{C}$ 


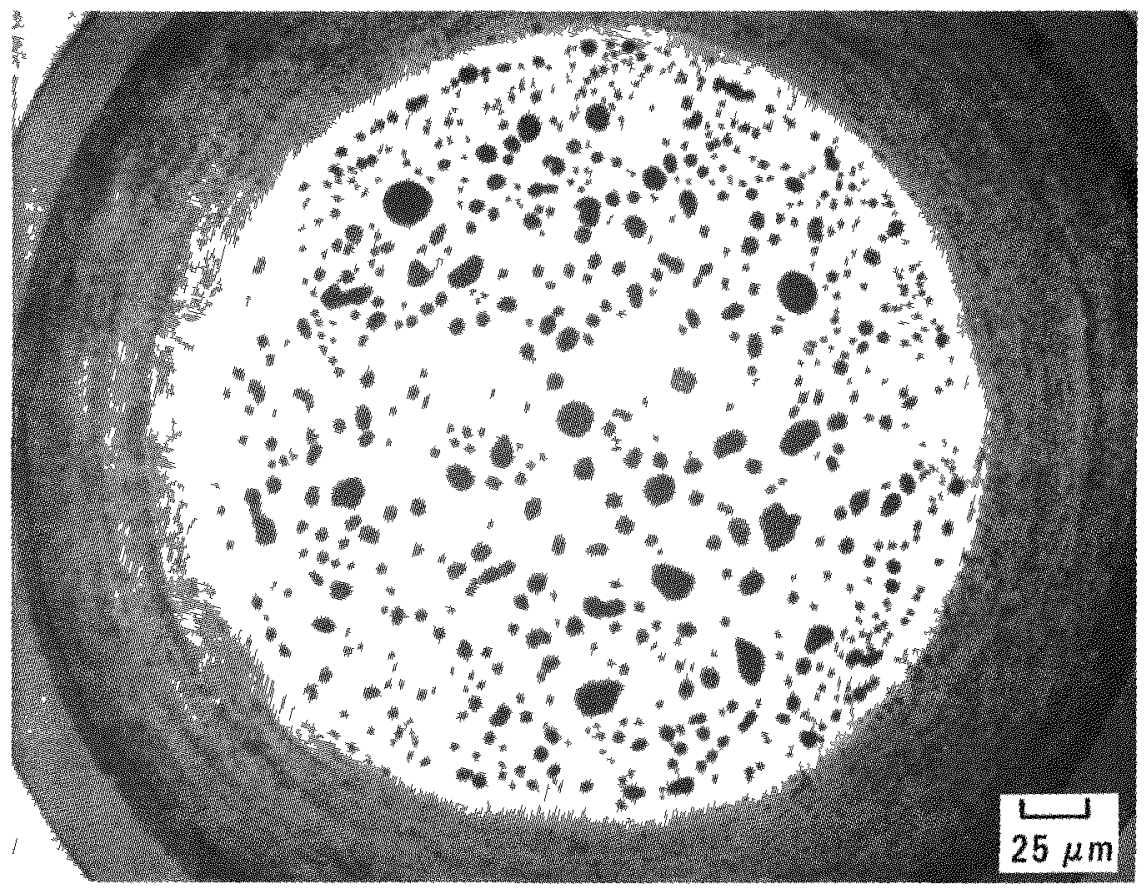

L7925-93

(a)

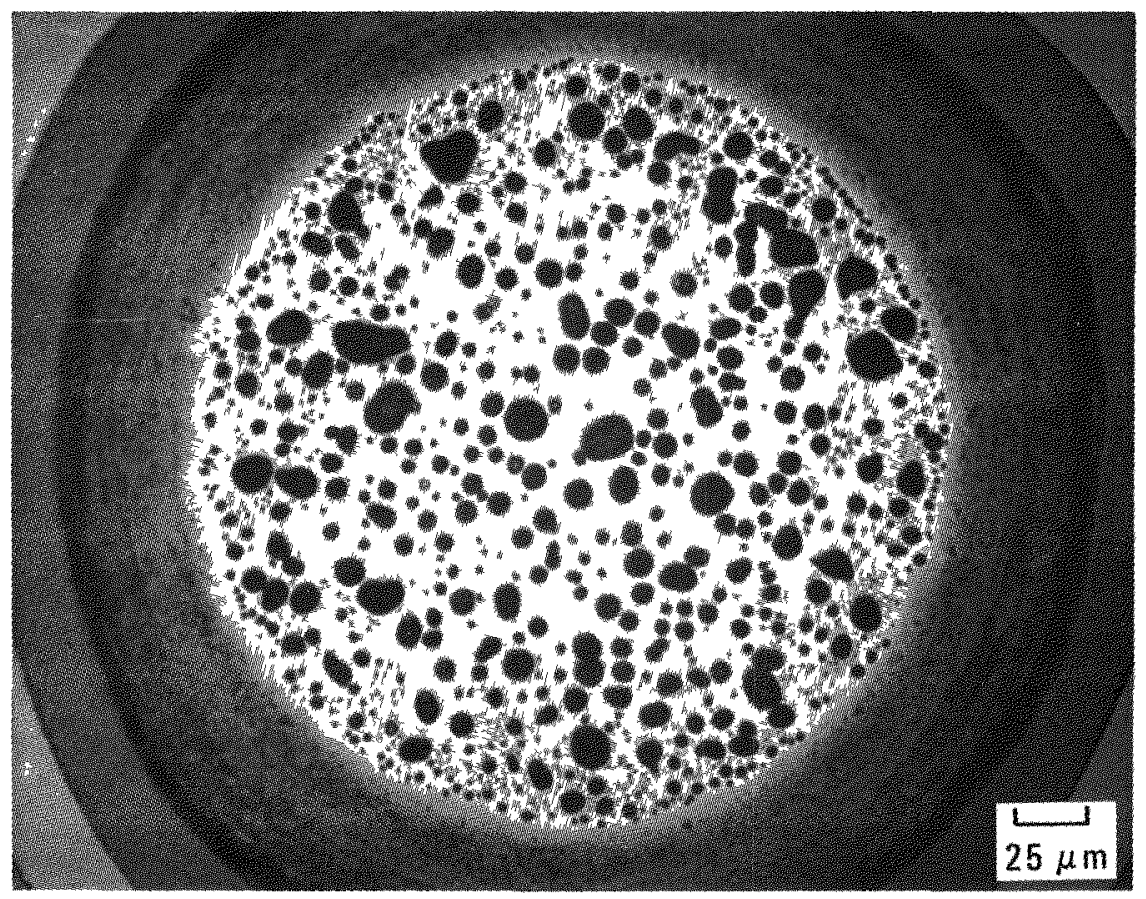

L7925.125

(b)

Fig. 5-15. Postirradiation appearance of UC 2 TRISO kernels: (a) (6151-21$0120-2) 3.9 \times 10^{25} \mathrm{n} / \mathrm{m}^{2}$ (E > 29 fJ) HTGR $_{\text {fast }}$ fluence, $22.5 \%$ FIMA and time-average maximum particle surface temperature of $915^{\circ} \mathrm{C}$ and (b) $(6151-21-0111-3) 6.6 \times 10^{25} \mathrm{n} / \mathrm{m}^{2}(\mathrm{E}>29 \mathrm{fJ})$ HTGR fast fluence, $26.6 \%$ FIMA and time-average maximum particle surface temperature of $905^{\circ} \mathrm{C}$ 


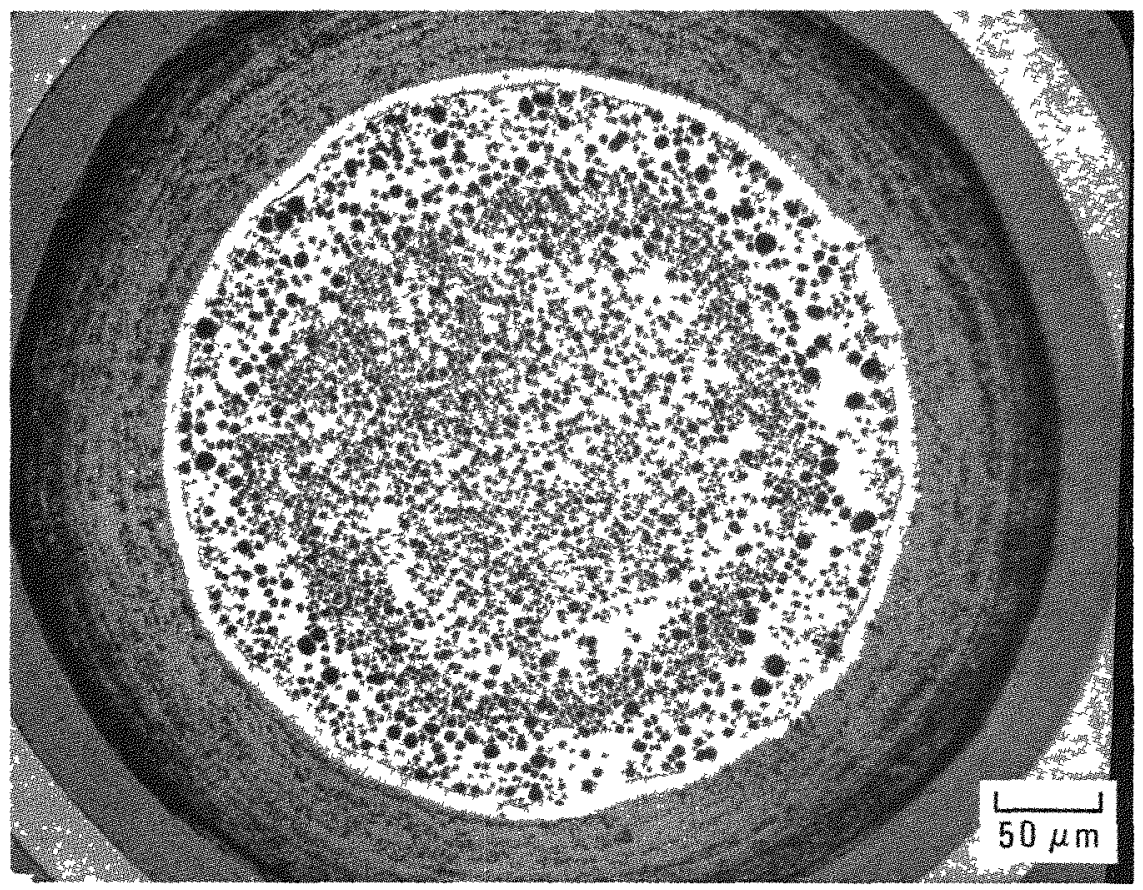

L7927-72

(a)

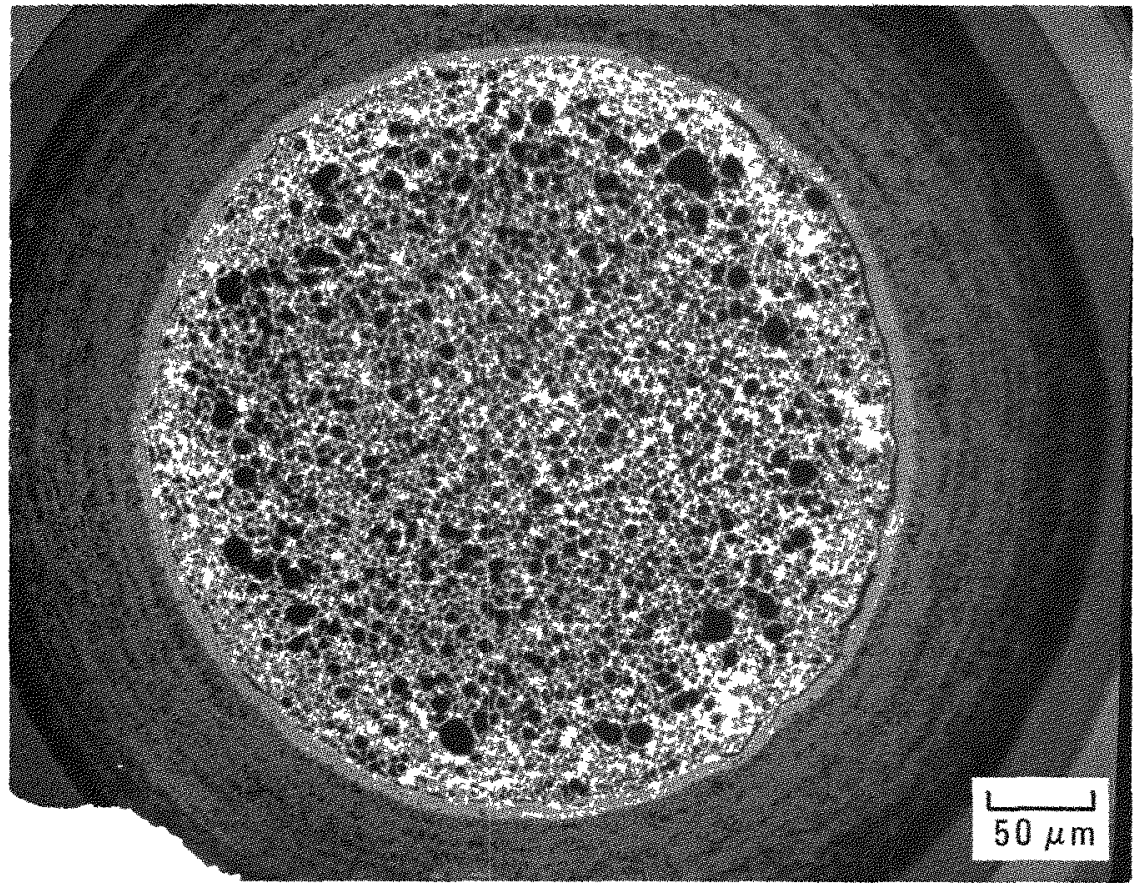

L7927-41

(b)

Fig. 5-16. Postirradiation appearance of $\mathrm{UC}_{0.77^{0}} .5$ TRISO kernels: (a) $(6157-08-0210-1) 4.3 \times 10^{25}$ (E > $29 \mathrm{fJ}$ ) HTGR fast fluence, $21.2 \%$ FIMA and time-average maximum particle surface temperature of $860^{\circ} \mathrm{C}$ and (b) $(6157-08-0210-3) 4.8 \times 10^{25} \mathrm{n} / \mathrm{m}^{2}$ (E > $\left.29 \mathrm{fJ}\right)_{\text {HTGR }}$ fast fluence, 24.2\% FIMA and time-average maximum particle surface temperature of $915^{\circ} \mathrm{C}$ 


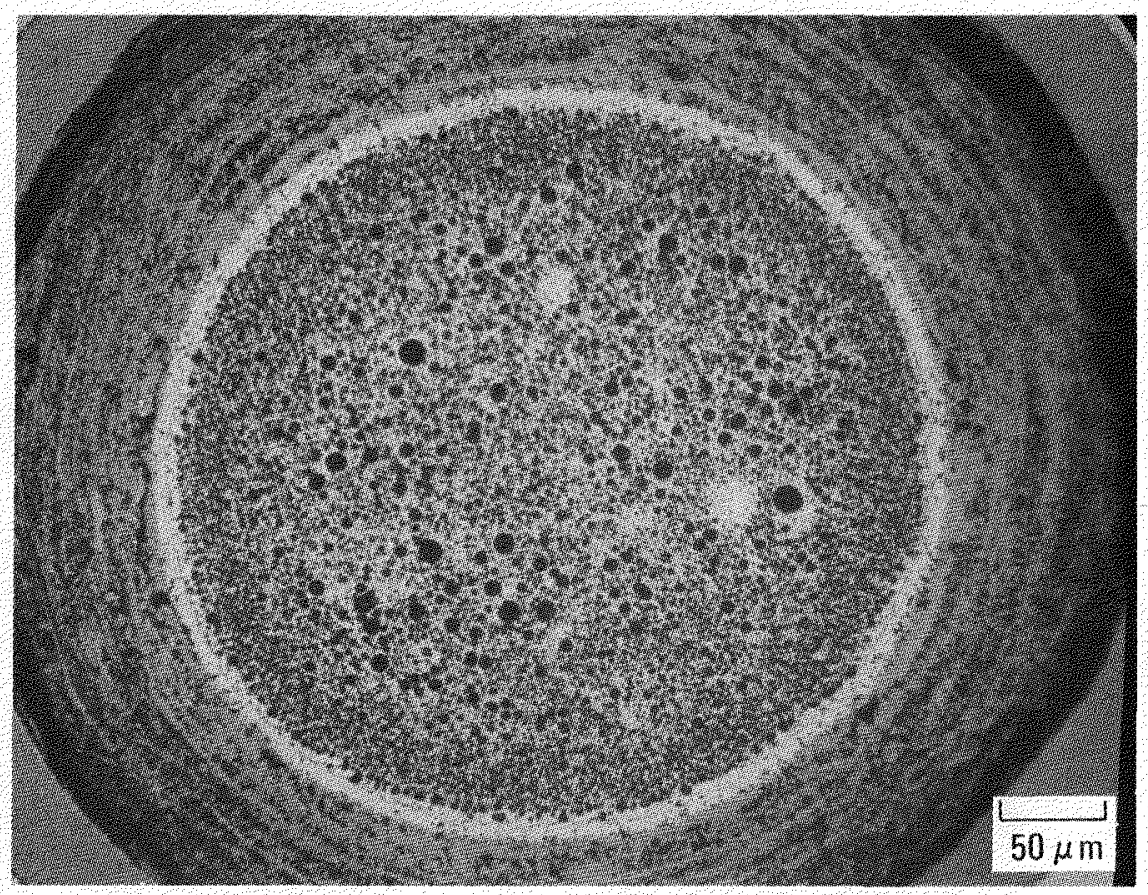

L7927.98

(a)

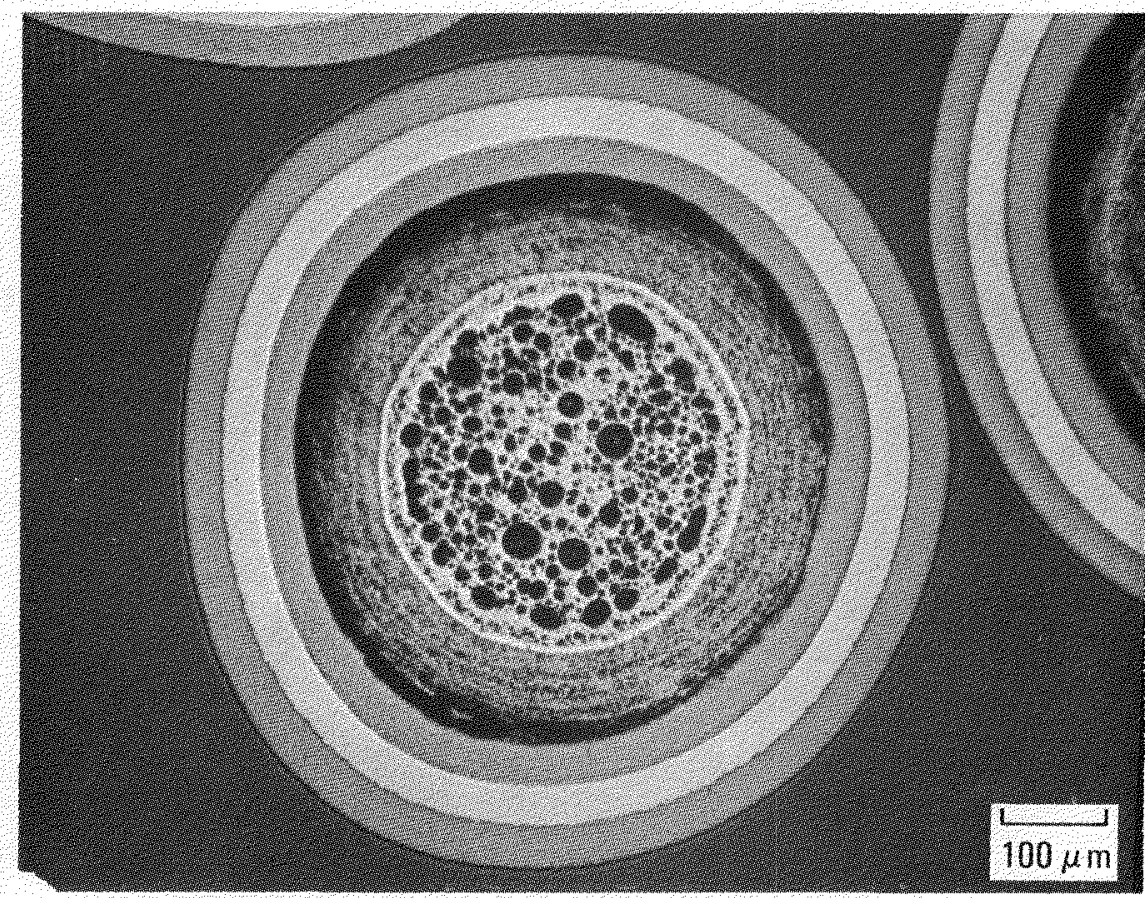

L7927-60

(b)

Fig. 5-17. Postirradiation appearance of UC $0.5^{0} 1.1$ TRISO kernels: (a) $(6157-08-0311-1) 4.0 \times 10^{25} \mathrm{n} / \mathrm{m}^{2}(\mathrm{E}>29 \text { fJ })_{\text {HTGR }}$ fast fluence, 20.3\% FIMA and time-average maximum particle surface temperature of $860^{\circ} \mathrm{C}$ and (b) $(6157-08-0320-6) 6.4 \times 10^{25} \mathrm{n} / \mathrm{m}^{2} \quad(\mathrm{E}>29 \mathrm{fJ}) \mathrm{HTGR}$ fast fluence, 26.6\% FIMA and time-average maximum particle surface temperature of $915^{\circ} \mathrm{C}$ 


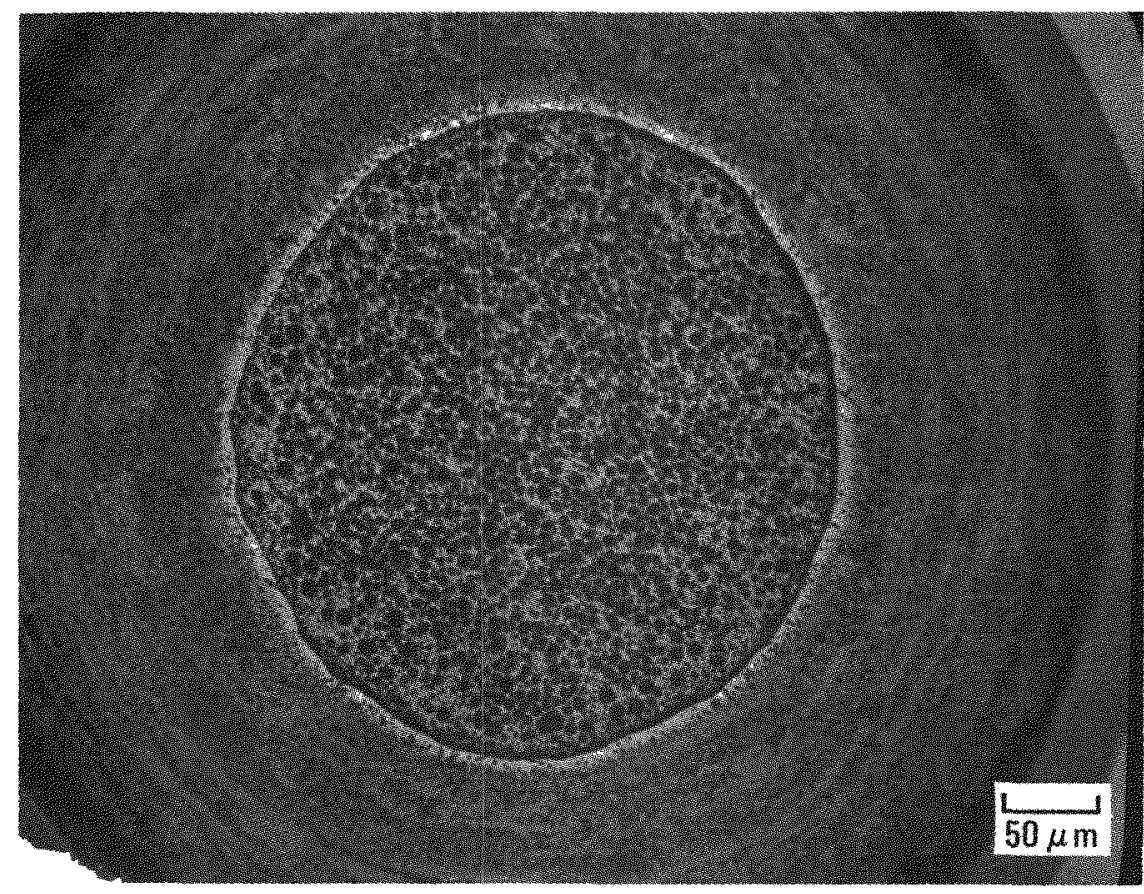

L7927 25

(a)

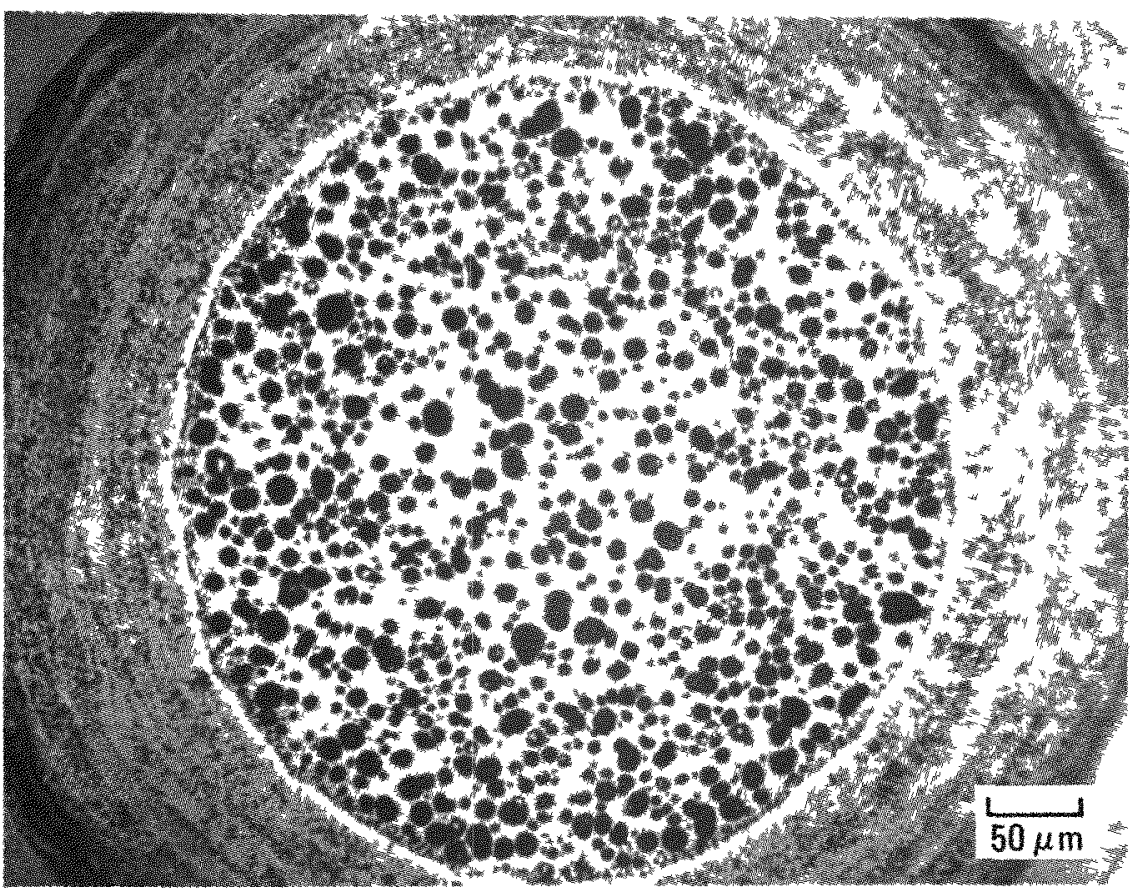

L7925.98

(b)

Fig. 5-18. Postirradiation appearance of UC $\mathrm{UC}_{2} \mathrm{O}_{1} .6$ TRISO kernels: (a) (6157-09-0120-5) $3.8 \times 10^{25} \mathrm{n} / \mathrm{m}^{2}(\mathrm{E}>29 \mathrm{fJ})$ HTGR fast fluence, 22.3\% FIMA and time-average maximum particle surface temperature of $915^{\circ} \mathrm{C}$ and (b) $(6157-09-0120-3) 6.5 \times 10^{25} \mathrm{n} / \mathrm{m}^{2}(\mathrm{E}>29 \mathrm{fJ})_{\mathrm{HTGR}}$ fast fluence, $26.5 \%$ FIMA and time-average maximum particle surface temperature of $905^{\circ} \mathrm{C}$ 


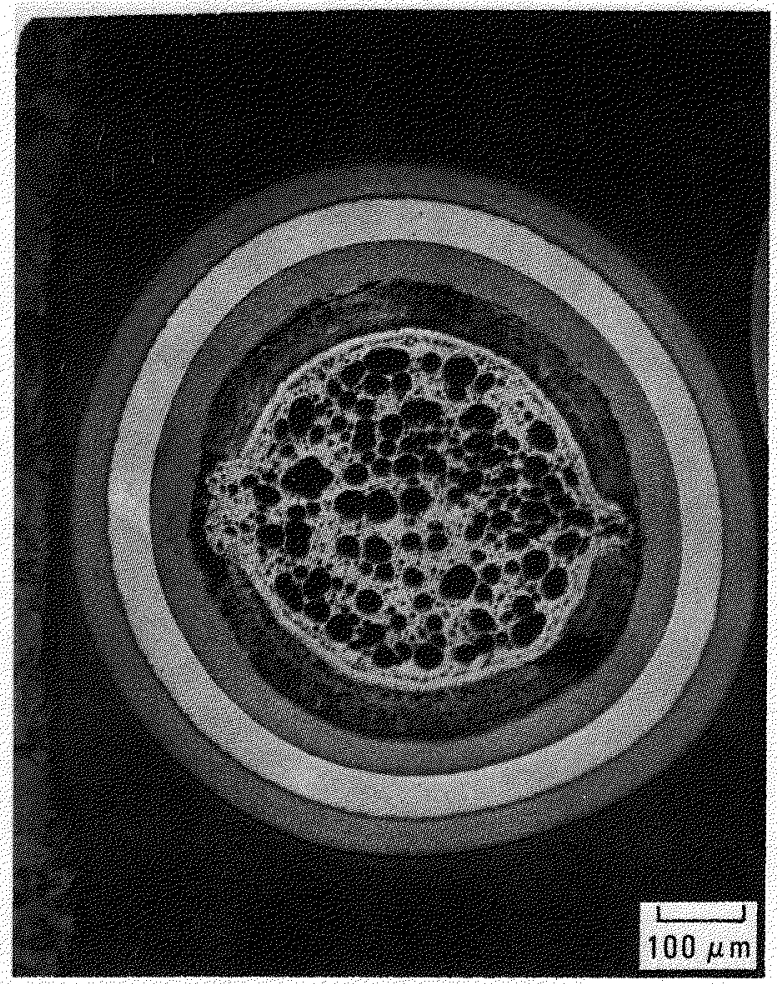

L7927.63 (a)

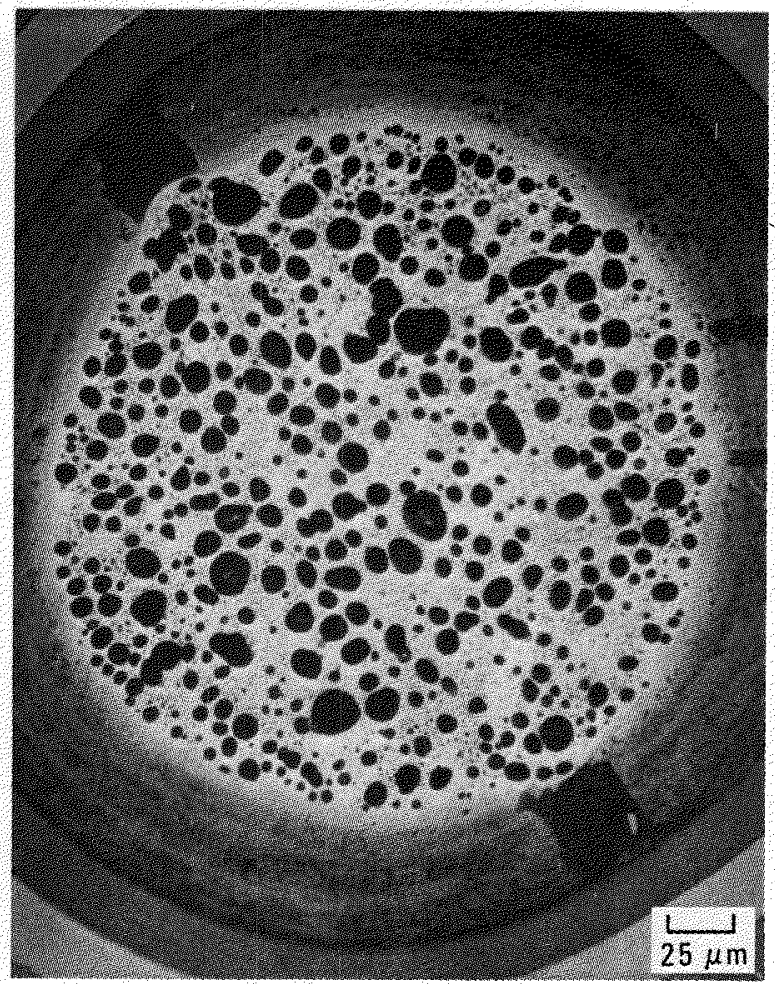

(b)

Fig. 5-19. Examples of kernel extrusion into buffer cracks/voids: (a) $\mathrm{UC}_{0.5} 0_{1.1}$ particles $(6157-08-0320-6), 6.4 \times 10^{25}$ (E > 29 fJ) HTGR fast fluence, 26.6\% FIMA and (b) UC 2 TRISO particles (6151-21$0111-3), 6.6 \times 10^{25} \mathrm{n} / \mathrm{m}^{2}(\mathrm{E}>29 \mathrm{fJ})$ HTGR fast fluence, $26.6 \%$ FIMA. Both had time-average maximum particle surface temperatures of $\sim 900^{\circ} \mathrm{C}$ 


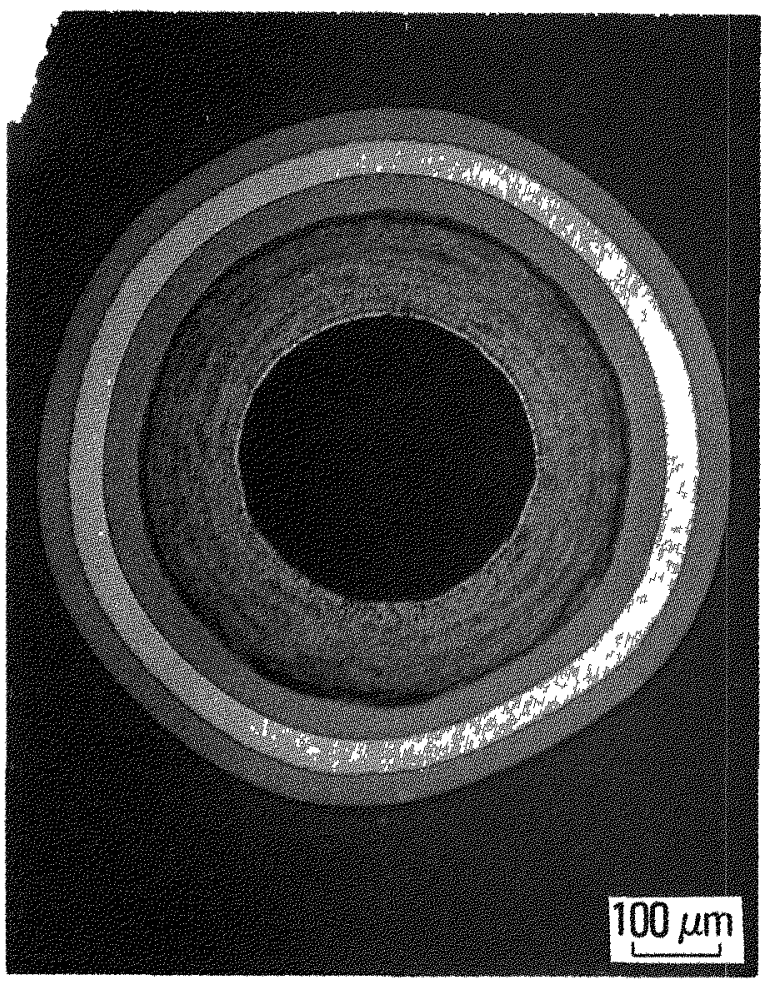

L7927.81

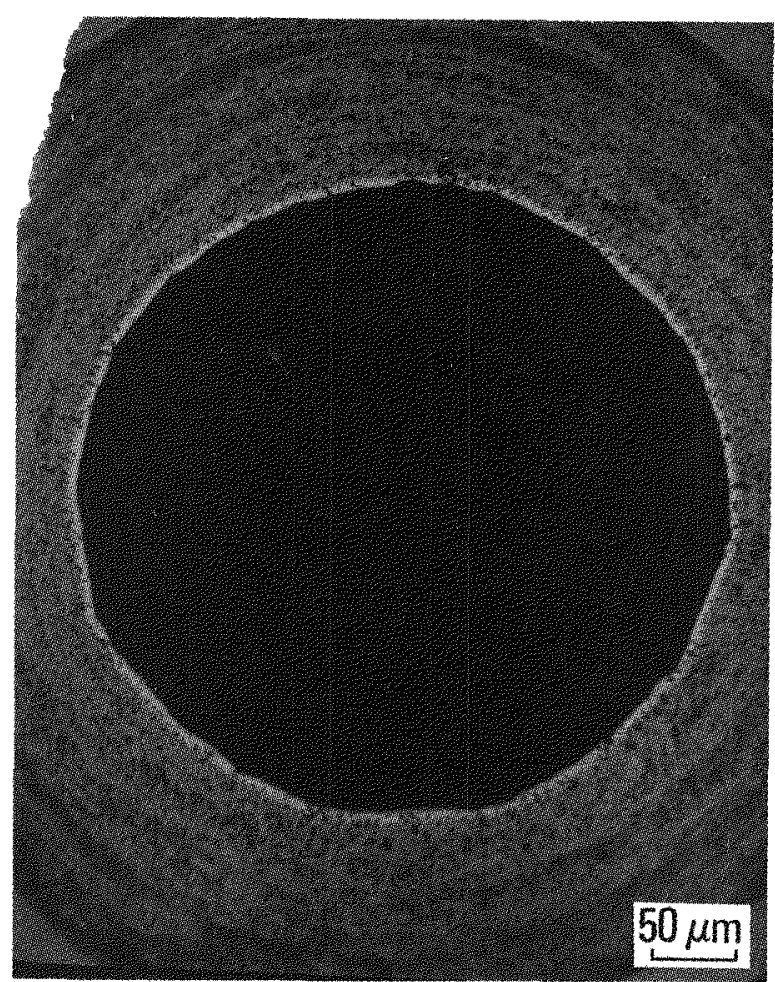

L7927-82

Fig. 5-20, Postirradiation appearance of TRISO particle from tray No. 168 without the kerne1, showing densified buffer caused by fission recoils: $3.8 \times 10^{25} \mathrm{n} / \mathrm{m}^{2}$ ( $\mathrm{E}>29 \mathrm{fJ}$ ) HTGR fast fluence at a time-average maximum particle surface temperature of $915^{\circ} \mathrm{C}$ 


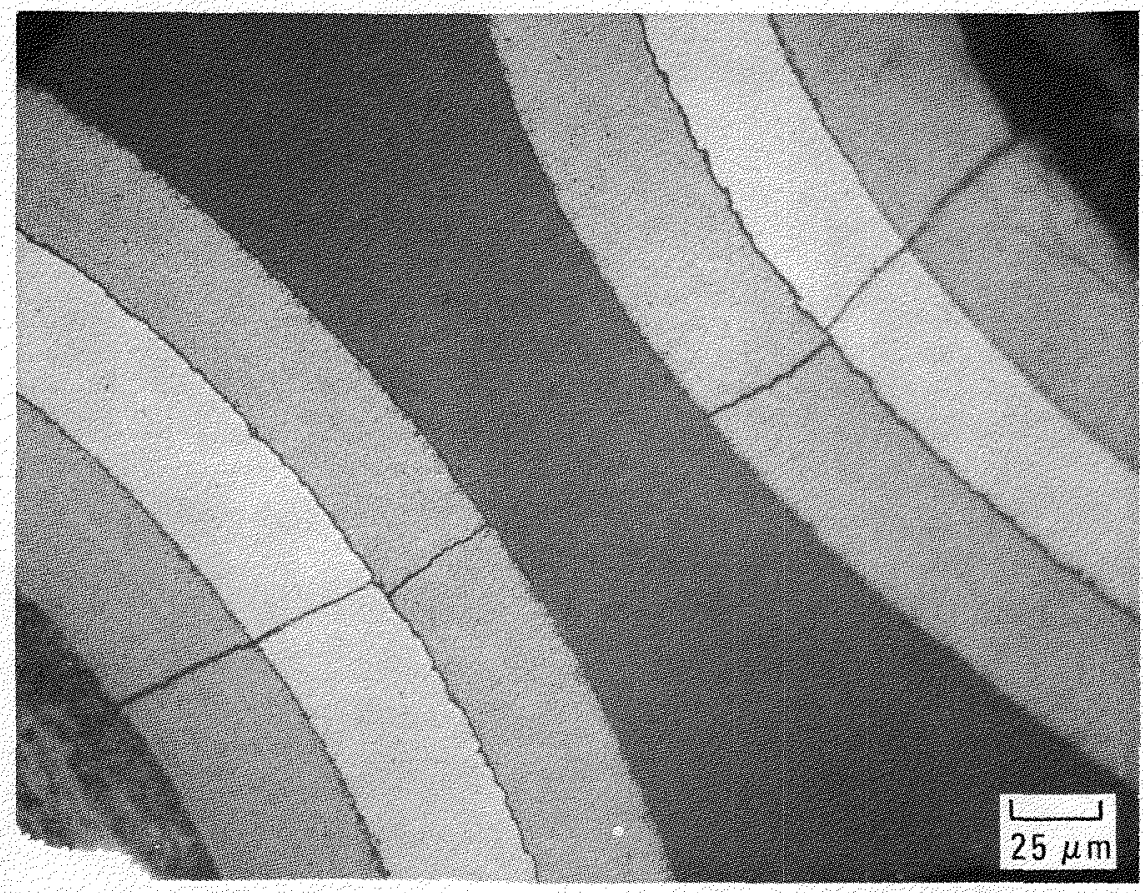

L7927-67

(a)

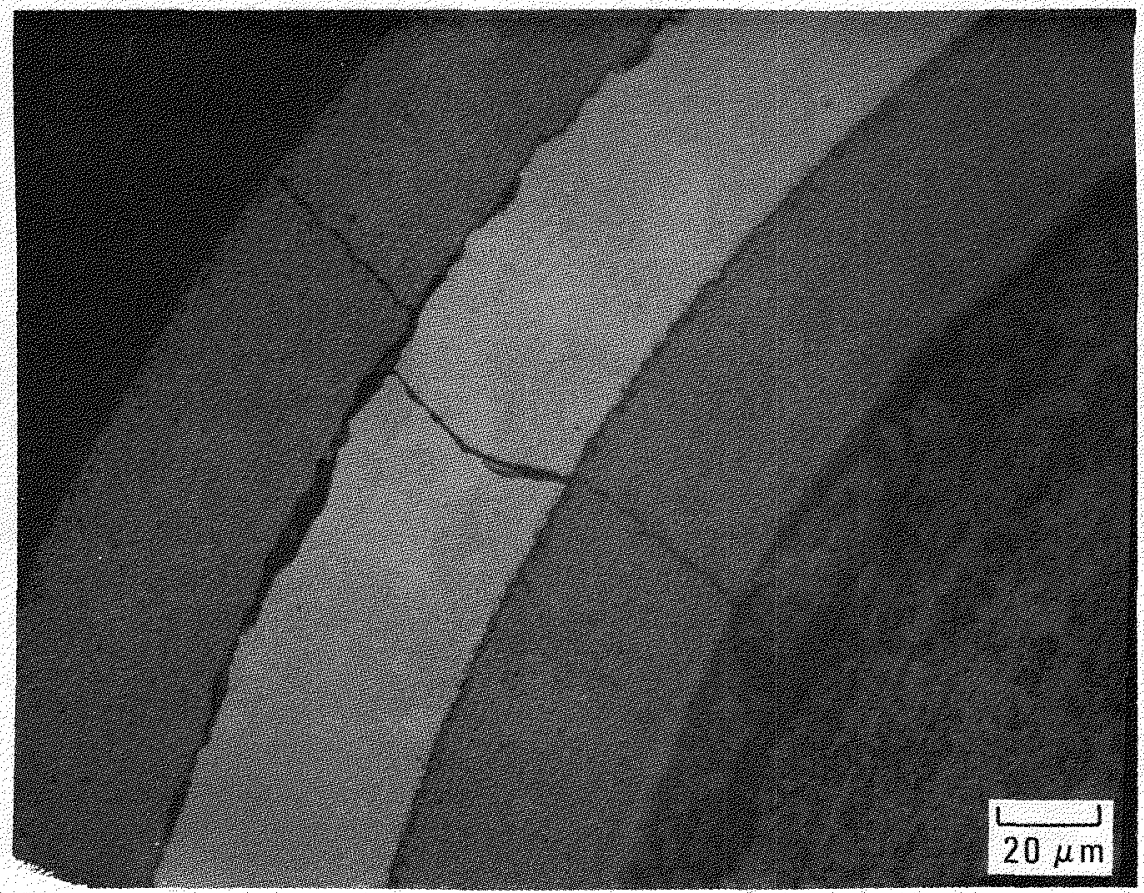

L7927-32

(b)

Fig. 5-21. Examples of TRISO coating cracks believed to be an artifact of mount preparation: (a) (6157-08-0320-6) $6.4 \times 10^{25} \mathrm{n} / \mathrm{m}^{2}$ $(\mathrm{E}>29 \mathrm{fJ})_{\text {HTGR }}$ fast fluence, $26.6 \%$ FIMA and time-average maximum particle surface temperature of $915^{\circ} \mathrm{C}$ and (b) (615709-0120-5) $3.8 \times 10^{25} \mathrm{n} / \mathrm{m}^{2}(\mathrm{E}>29 \mathrm{fJ})_{\text {HTGR }}$ fast fluence, 22.3\% FIMA and time-average maximum particle surface temperature of $915^{\circ} \mathrm{C}$ 


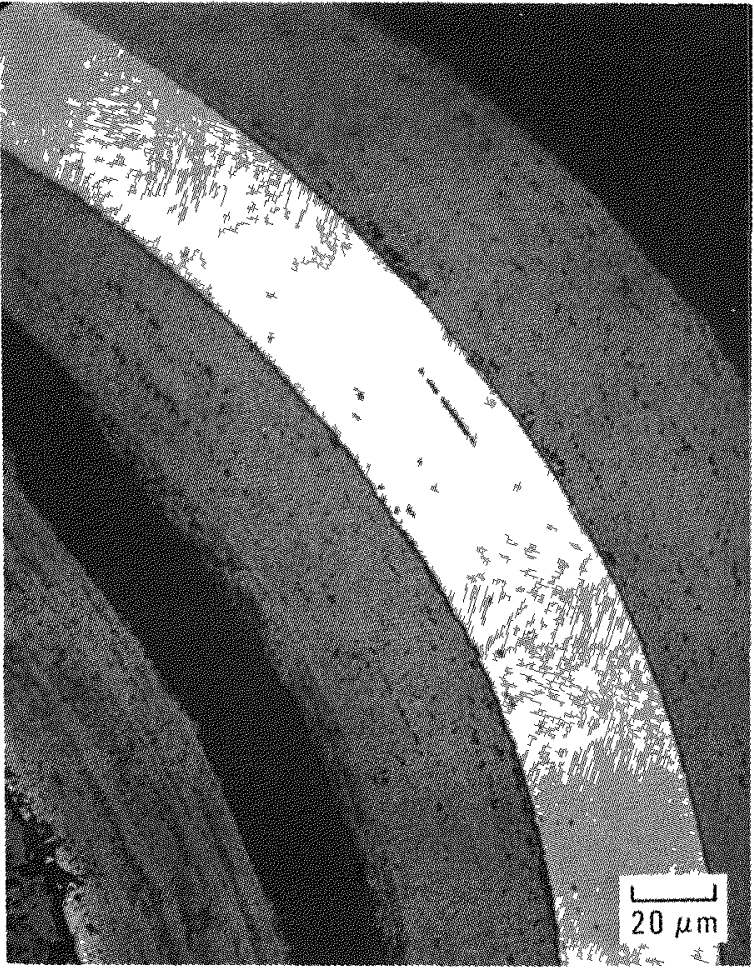

L7927-8

(a)

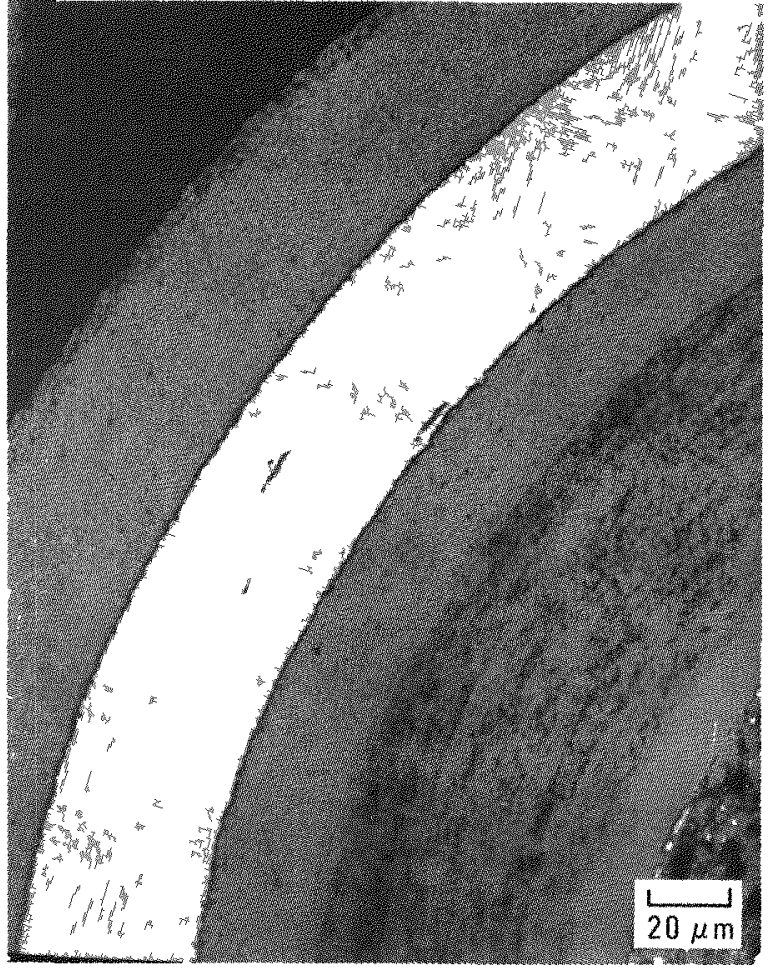

(b)

Fig. 5-22. Examples of short, lenticular flaws observed in unbonded particles irradiated in HRB-15B: (a) (6252-15-0140-3) $6.4 \times 10^{25} \mathrm{n} / \mathrm{m}^{2}$ (E $\left.>29 \mathrm{EJ}\right)_{\text {HTGR }}$ fast fluence, $5.7 \%$ FIMA and time-average maximum particle surface temperature of $860^{\circ} \mathrm{C}$ and (b) $(6155-05-0111-3) 6.6 \times 10^{25} \mathrm{n} / \mathrm{m}^{2}$ (E $>29 \mathrm{fJ}$ ) HTGR fast fluence, $16.4 \%$ FJMA and time-average maximum particle surface temperature of $885^{\circ} \mathrm{C}$ 


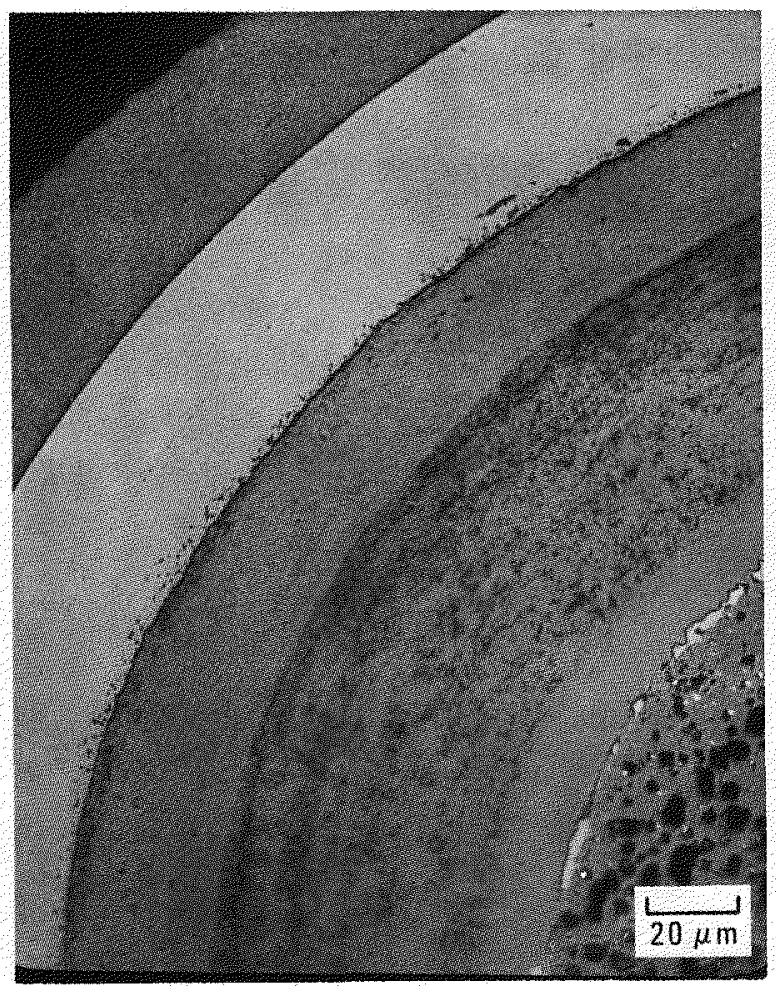

L7927.14 (a)

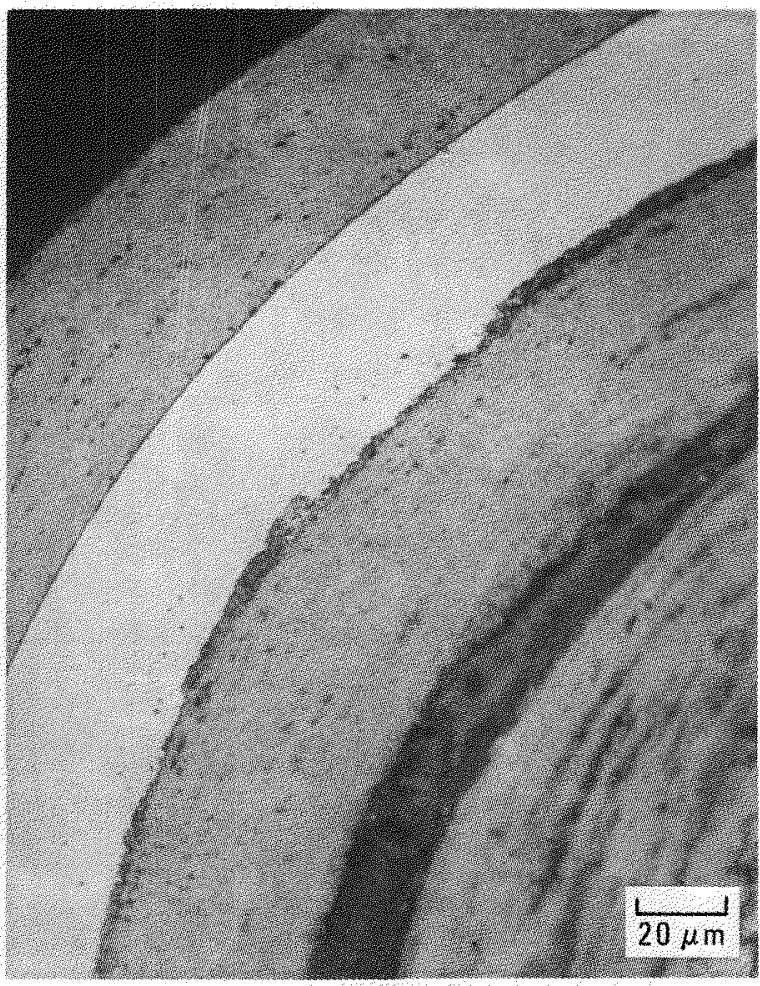

(b)

Fig. 5-23. SiC porosity type observed in HRB-15B particles on only the inner half of the SiC layer: (a) $(6155-05-0111-3) 6.6 \times 10^{25}$ $\mathrm{n} / \mathrm{m}^{2}(\mathrm{E}>29 \mathrm{fJ})_{\mathrm{HTGR}}$ fast fluence, 16.4\% FIMA and time-average maximum particle surface temperature of $885^{\circ} \mathrm{C}$ and (b) (625215-0140-3) $6.4 \times 10^{25} \mathrm{n} / \mathrm{m}^{2}(\mathrm{E}>29 \mathrm{fJ})$ HTGR fast fluence, $5.7 \%$ FIMA, and time-average maximum particle surface temperature of $860^{\circ} \mathrm{C}$ 


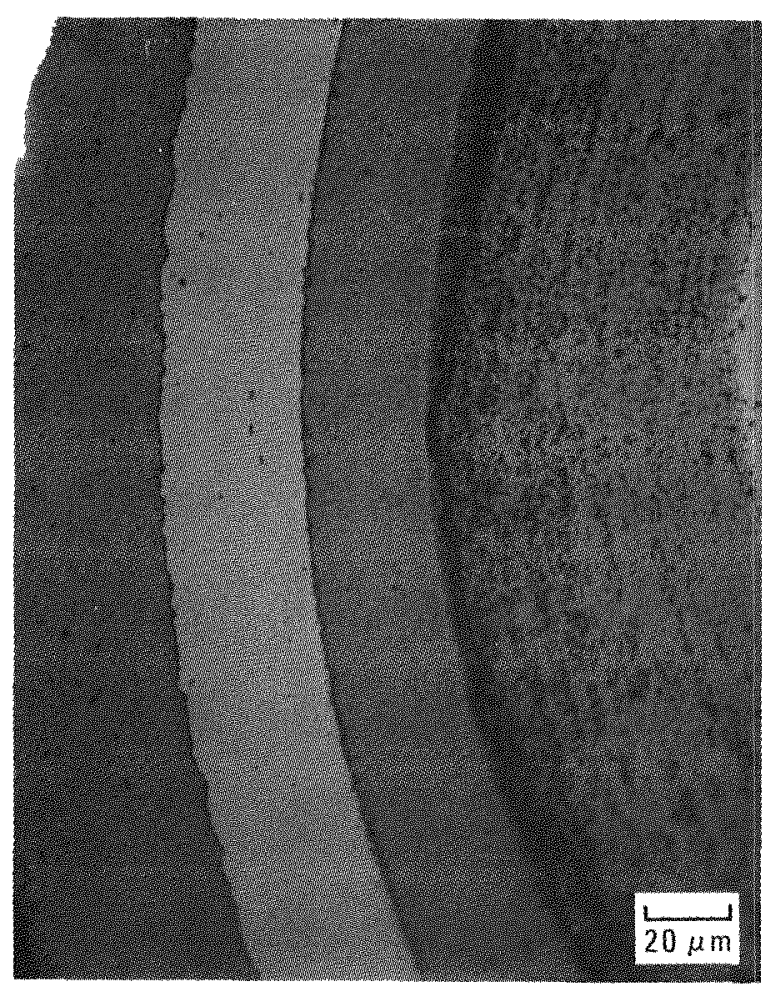

L7927 50 (a)

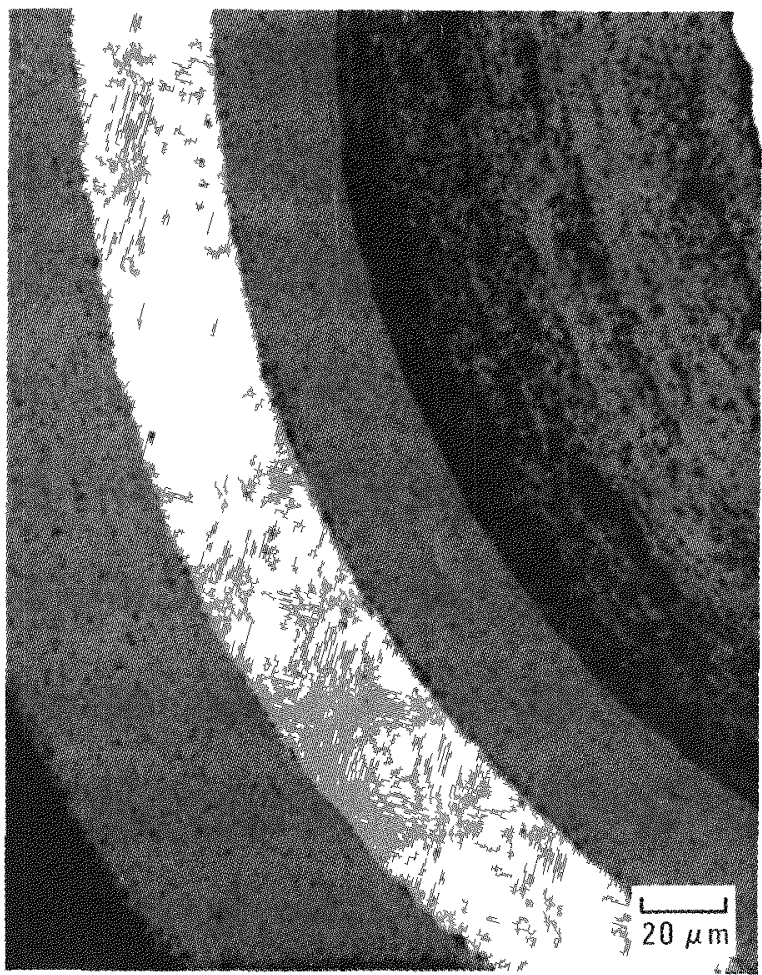

MP80037 2

(b)

Fig. 5-24. SiC porosity type observed both in irradiated $\mathrm{HRB}-15 \mathrm{~B} U \mathrm{UC}_{\mathrm{X}} \mathrm{O}_{\mathrm{y}}$ particles and in unirradiated particles from the same batches: (a) (6157-08-0210-3) irradiated at $4.8 \times 10^{25} \mathrm{n} / \mathrm{m}^{2}(\mathrm{E}>29$ fJ) HTGR fast fluence, 24.2\% FIMA and time-average maximum particle surface temperature of $915^{\circ} \mathrm{C}$ and (b) unirradiated 


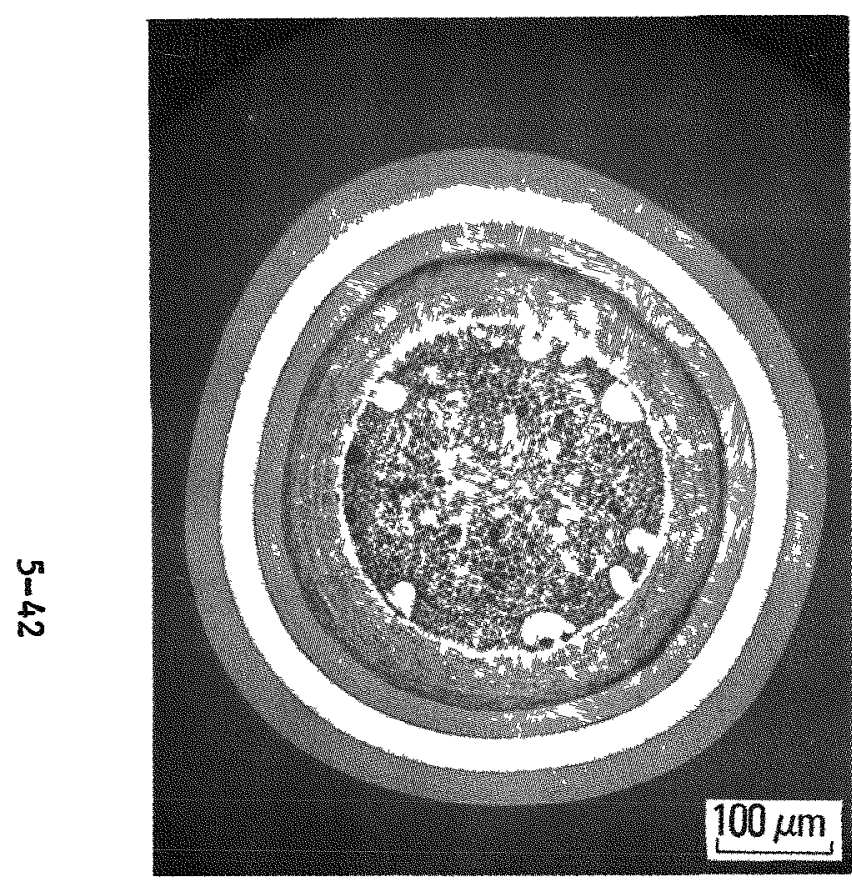

L7925-18

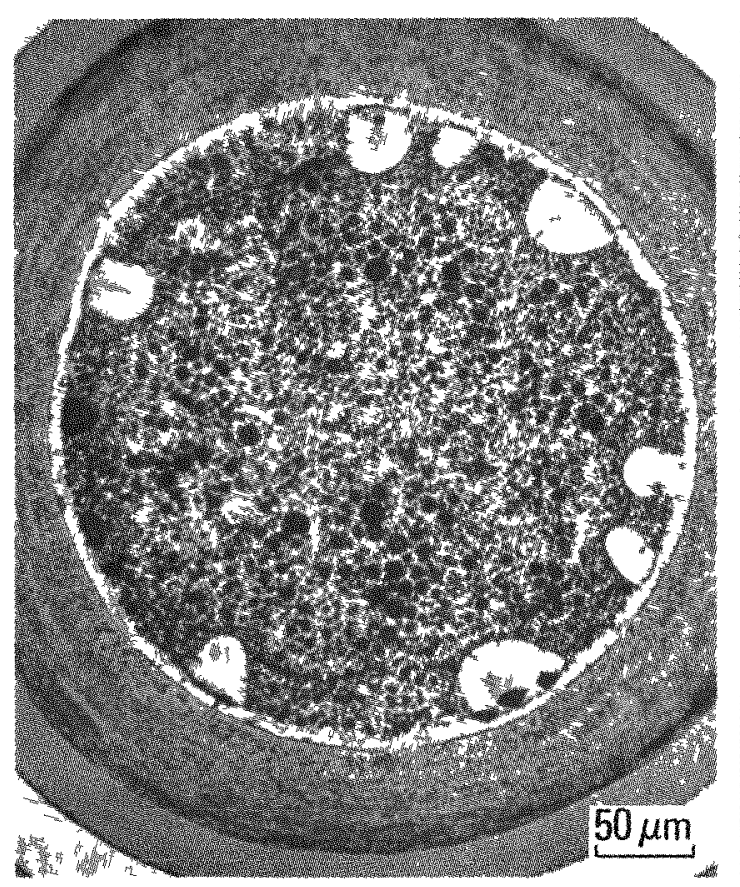

L7925-13

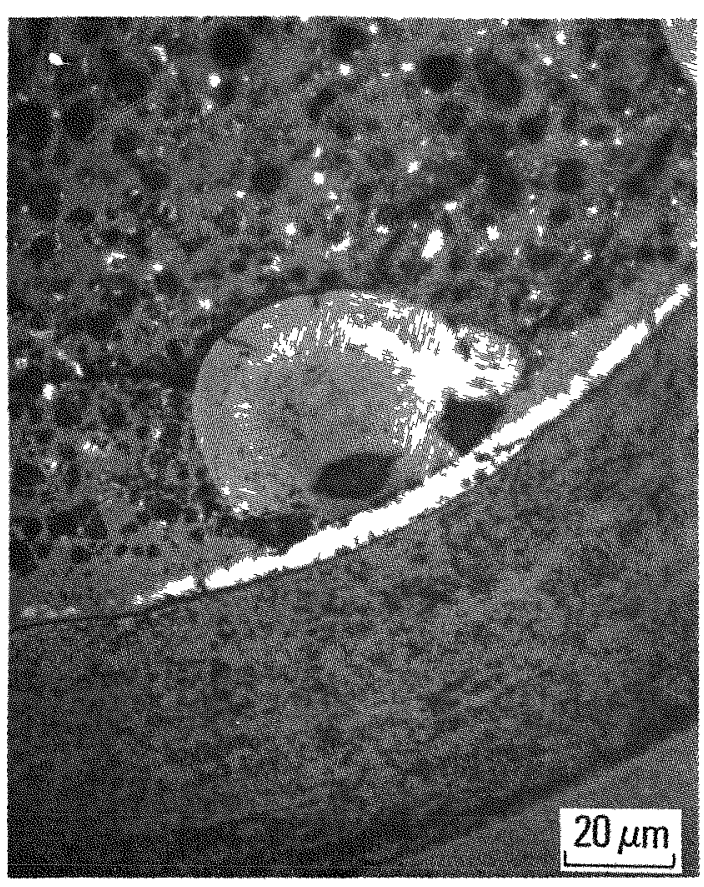

$\mathbf{L} 792512$

Fig. 5-25. Postirradiation appearance of a UC 2 TRISO particle with a solid layer of ZrC around the kernel: (6152-03-0111-3) $6.6 \times 10^{25} \mathrm{n} / \mathrm{m}^{2}$ (E > $\left.29 \mathrm{fJ}\right)$ HTGR fast fluence, $26.6 \%$ FIMA and time-average maximum particle surface temperature of $905^{\circ} \mathrm{C}$. The free carbon formed when $\mathrm{ZrC}$ reacts with oxygen has apparently been rejected back into the kernel to form the growth features shown. 


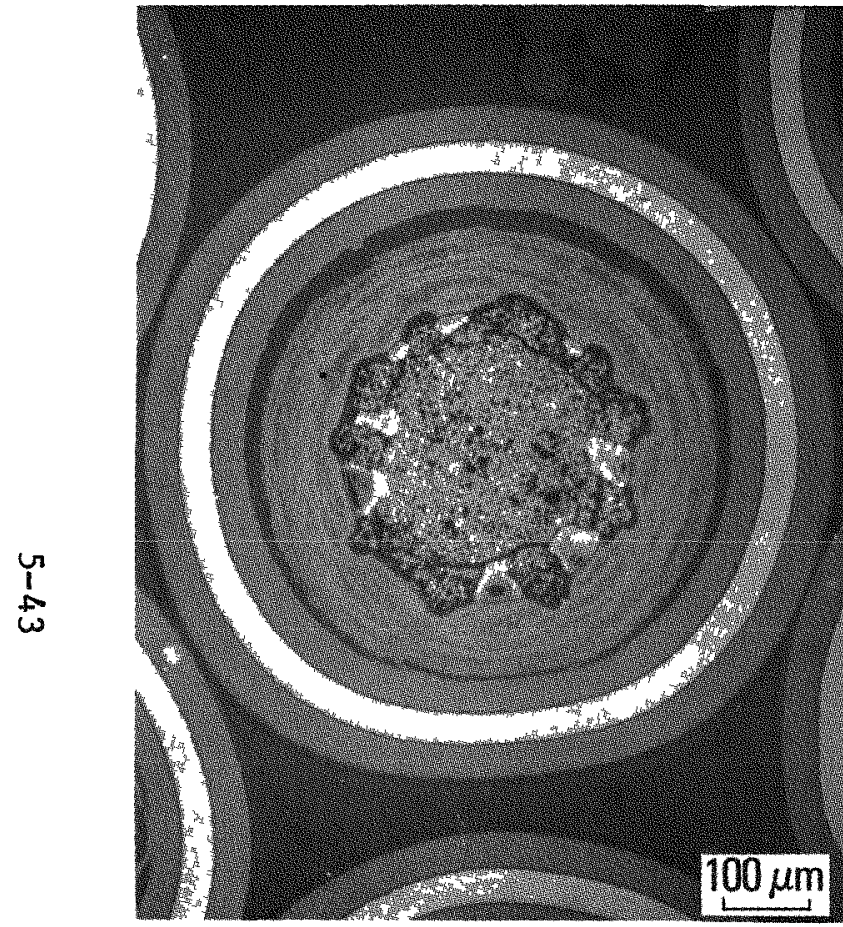

L7925-66

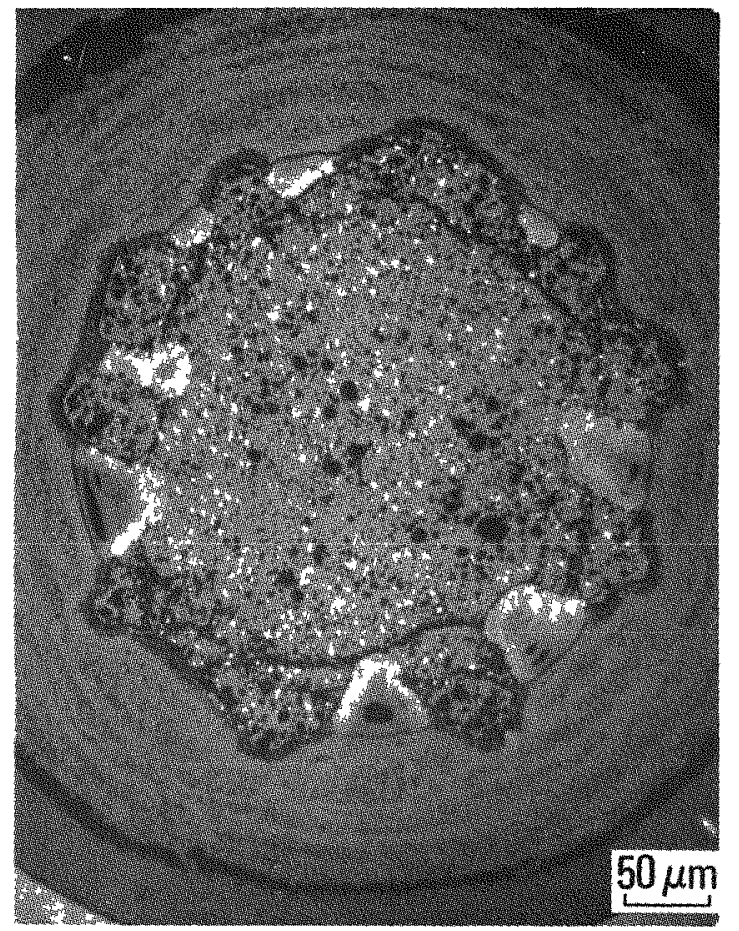

L7925-67

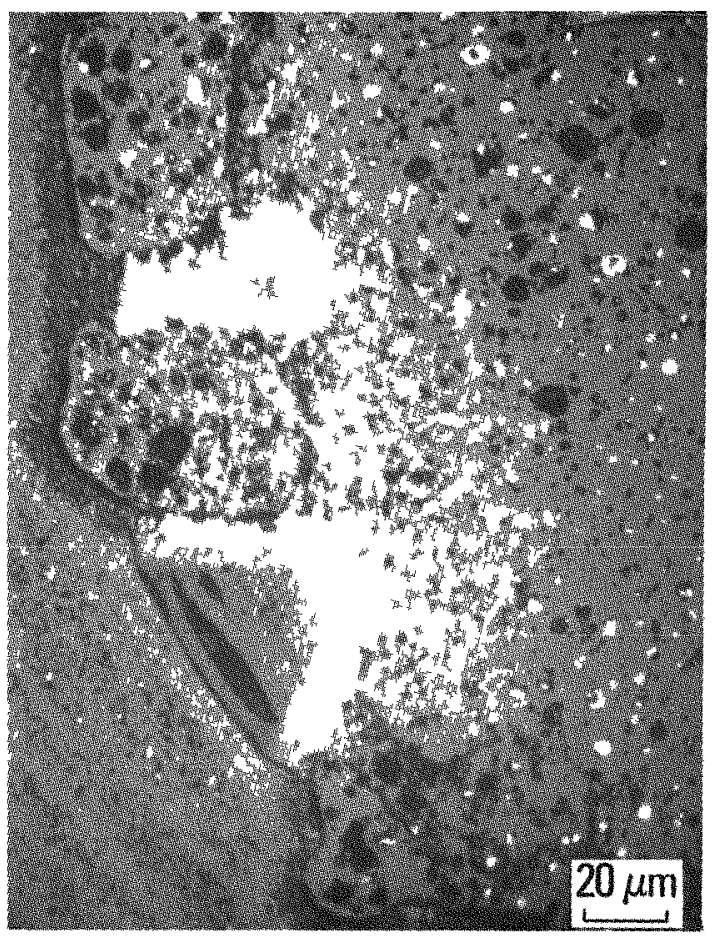

L7925-68

Fig. 5-26. Postirradiation appearance of a UO2 TRISO particle with ZrC dispersed throughout the buffer layer: $(6152-02-0110-1) 6.1 \times 10^{25} \mathrm{n} / \mathrm{m}^{2}$ (E > $\left.29 \mathrm{fJ}\right)$ HTGR fast fluence, $26.2 \%$ FIMA and timeaverage maximum particle surface temperature of $915^{\circ} \mathrm{C}$. Carbon growth features are again observed in the kernel. 


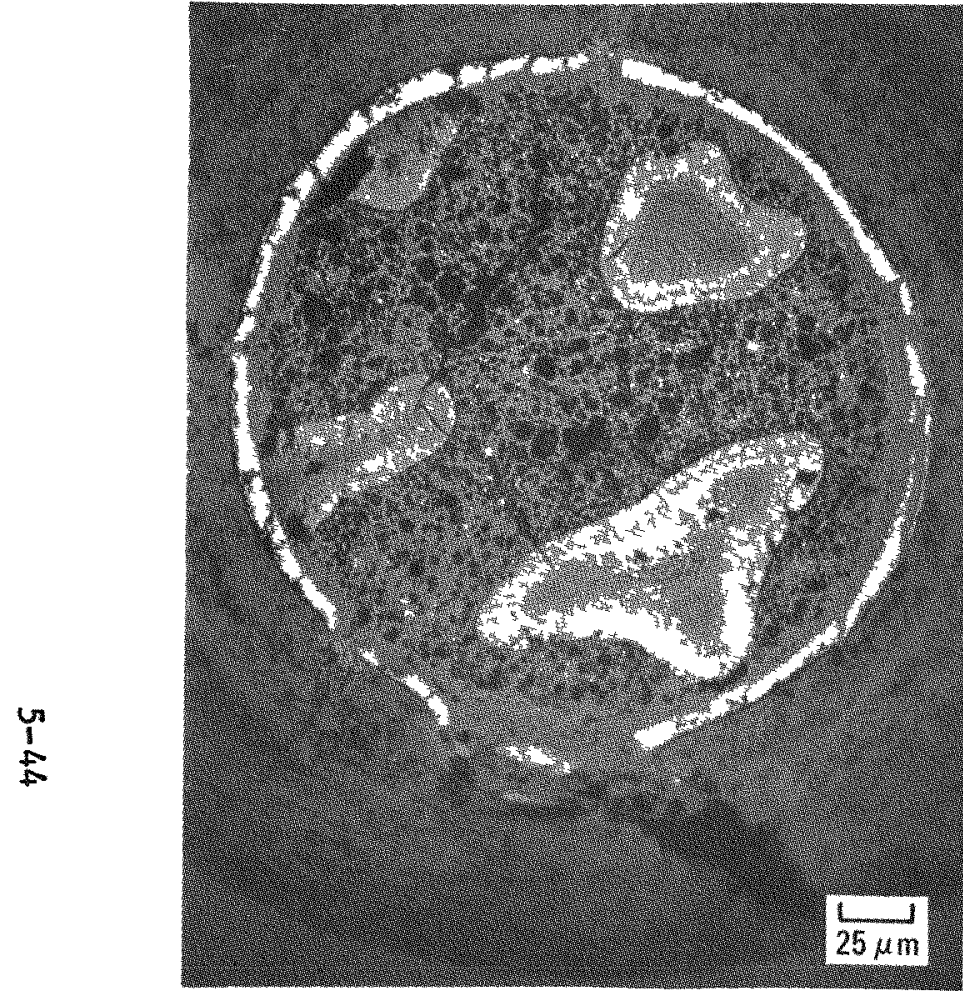

L7925 114

(a)

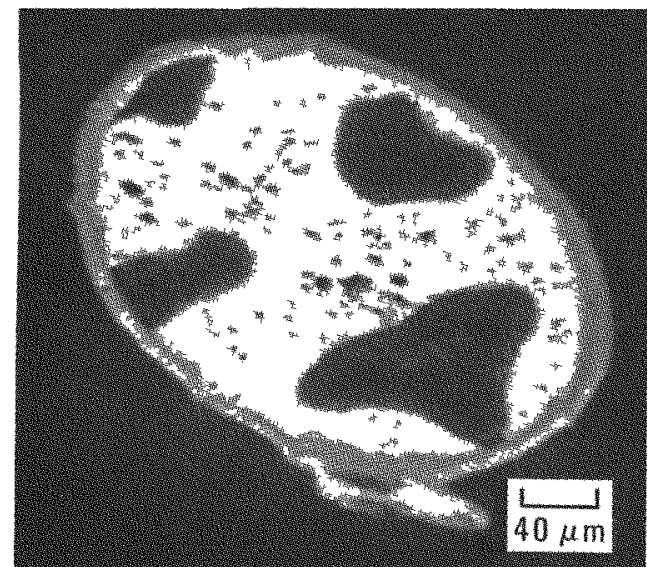

(b)

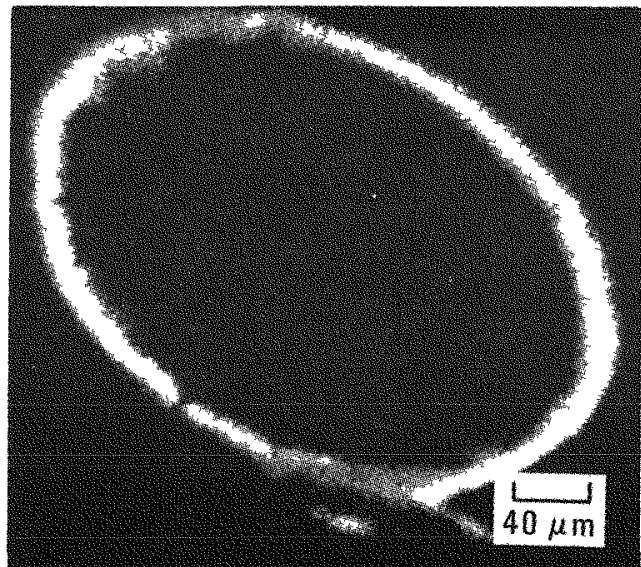

(d)

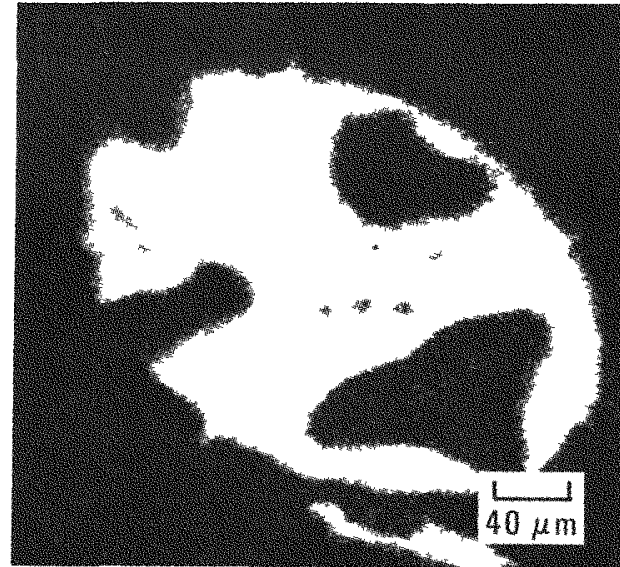

(c)

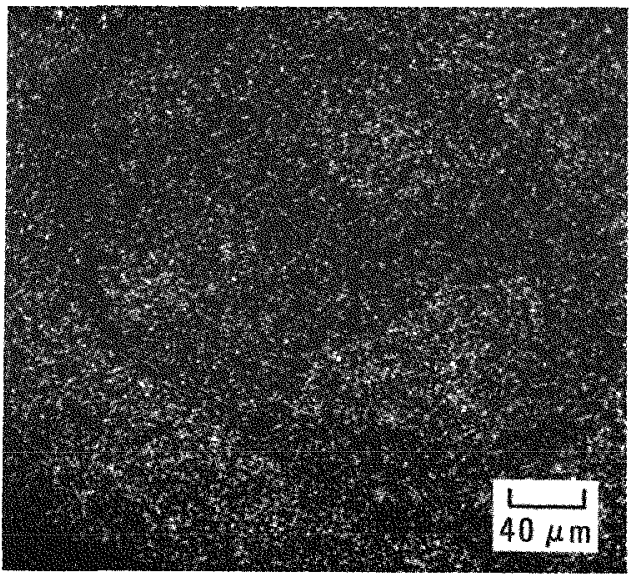

(e)

Fig. 5-27. Electron microprobe photos to determine the chemical composition of growth features: (a) optical micrograph, (b) back-scattered electron image, (c) U $\mathrm{M} \alpha$, (d) $\mathrm{Zr} \mathrm{L} \alpha$, and (e) $\mathrm{Ce} \mathrm{L} \alpha$. $(6447-02-0110-1) 4.8 \times 10^{25} \mathrm{n} / \mathrm{m}^{2}$ (E > $29 \mathrm{fJ}$ ) HTGR fast fluence, $22.5 \%$ FIMA and time-average maximum particle surface temperature of $860^{\circ} \mathrm{C}$. Cerium, palladium, ruthenium, neodymium, praseodymium, and molybdenum were distributed approximately like uranium, except that their concentrations were lower. Carbon shows up as the dark phase in (b). 


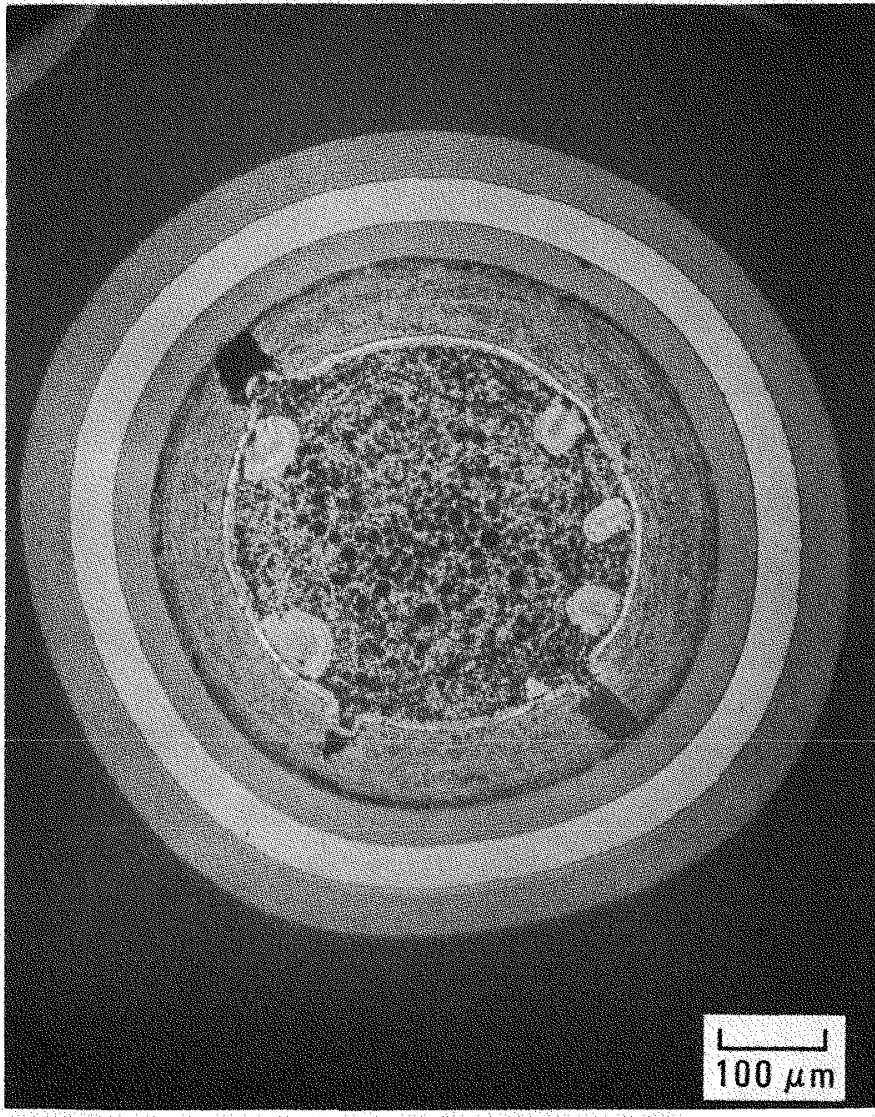

L7925-14

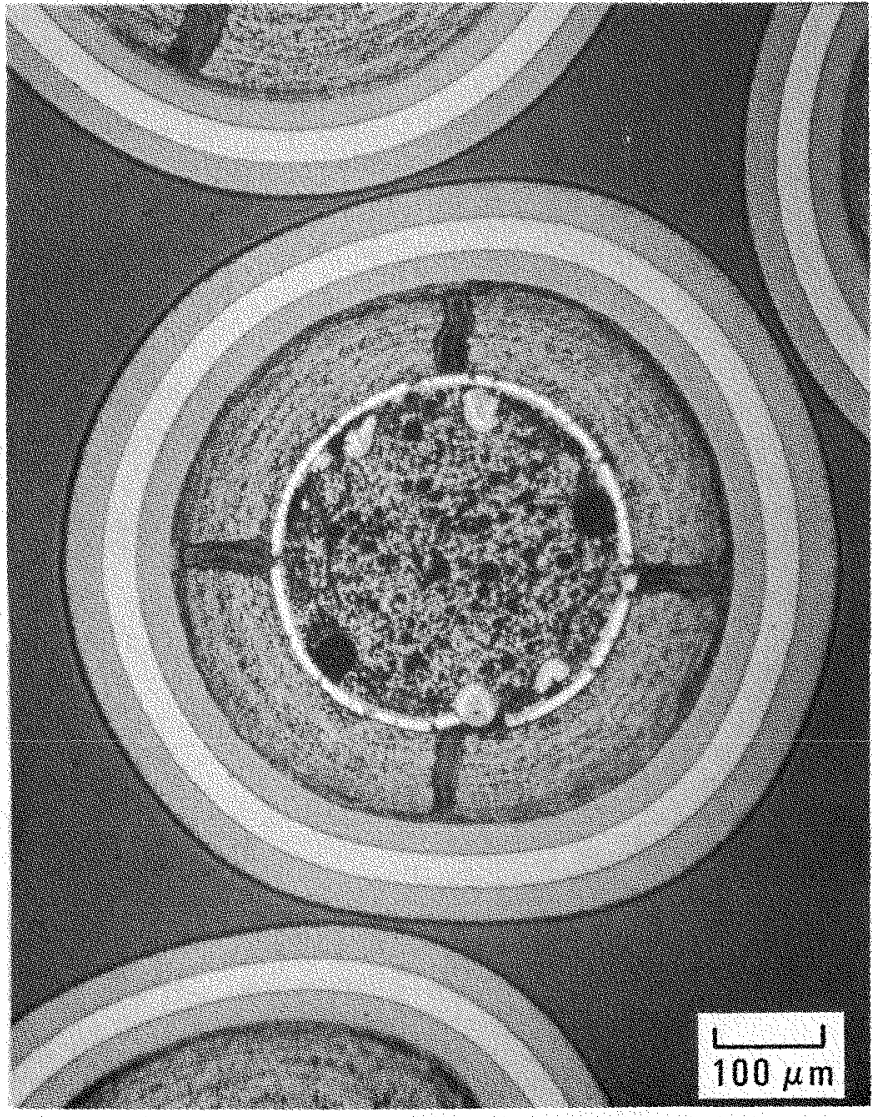

L7925-60

Fig. 5-28. Examples of buffer cracking in UC2 particles: (a) 5- $\mu \mathrm{m}$ ArC layer around kerne1 (6152-03$0111-3), 6.6 \times 10^{25} \mathrm{n} / \mathrm{m}^{2}$ ( $\left.\mathrm{E}>29 \mathrm{fJ}\right)_{\mathrm{HTGR}}$ fast fluence, $26.6 \%$ FIMA and time-average maximum particle surface temperature of $905^{\circ} \mathrm{C}$ and (b) $10-\mu \mathrm{m} \operatorname{ZrC}$ layer around kernel (6152-03-0210-2), $4.0 \times 10^{25} \mathrm{n} / \mathrm{m}^{2}$ (E $\left.>29 \mathrm{fJ}\right)_{\text {HTGR }}$ fast fluence, $22.8 \%$ FIMA and time-average maximum particle surface temperature of $915^{\circ} \mathrm{C}$. This is thought to be caused by a combination of two effects: (1) kernel swelling caused by the formation of the internal carbon growths and (2) lack of buffer shrinkage that occurs in the more heavily densified inner surface ring penetrated by fission recoils in ungettered particles [see (b)]. 


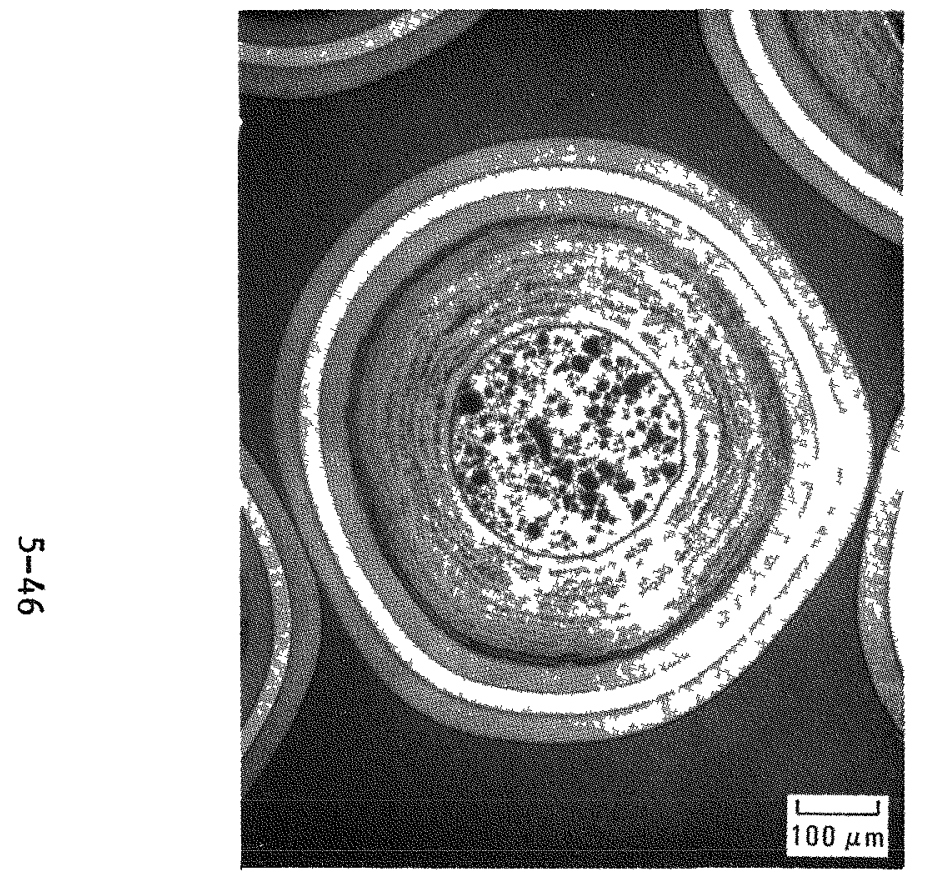

L $7925-20$ (a)

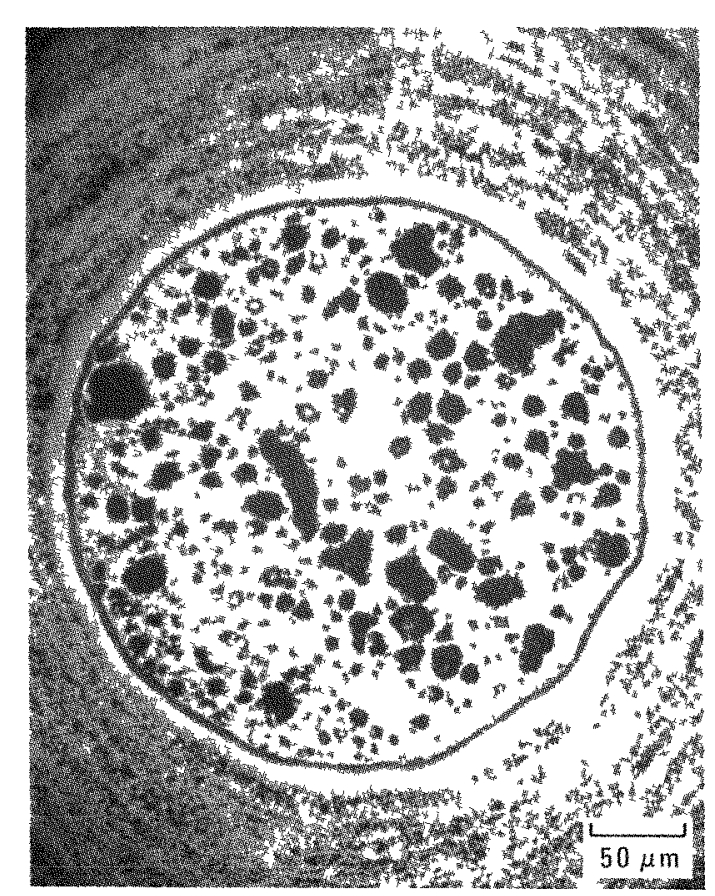

L7925-21

(b)

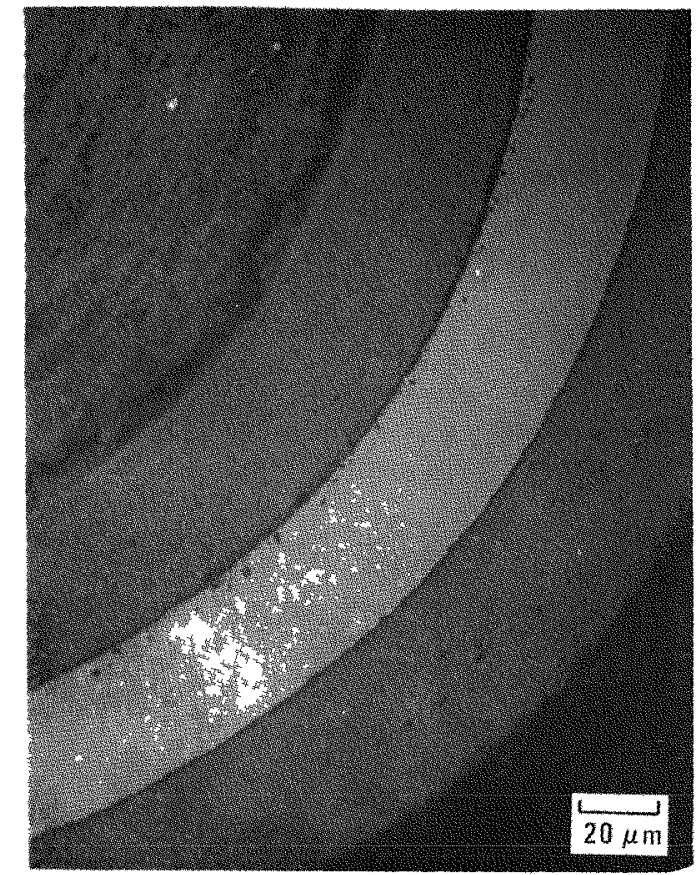

L7925-26

Fig. 5-29. An ungettered $\mathrm{UO}_{2}$ TRISO particle following irradiation: (6152-01-0120-3) $4.9 \times 10^{25} \mathrm{n} / \mathrm{m}^{2}$ $(\mathrm{E}>29 \mathrm{fJ})_{\mathrm{HTGR}}$ fast fluence, $24.2 \%$ FIMA and time-average maximum particle surface temperature of $915^{\circ} \mathrm{C}$. Note the larger gas bubbles in (b) compared to those in the previous ZrCgettered oxide particles. Note also in (c) the beginning of pin-hole chemical attack of the SiC diffusion barrier. 

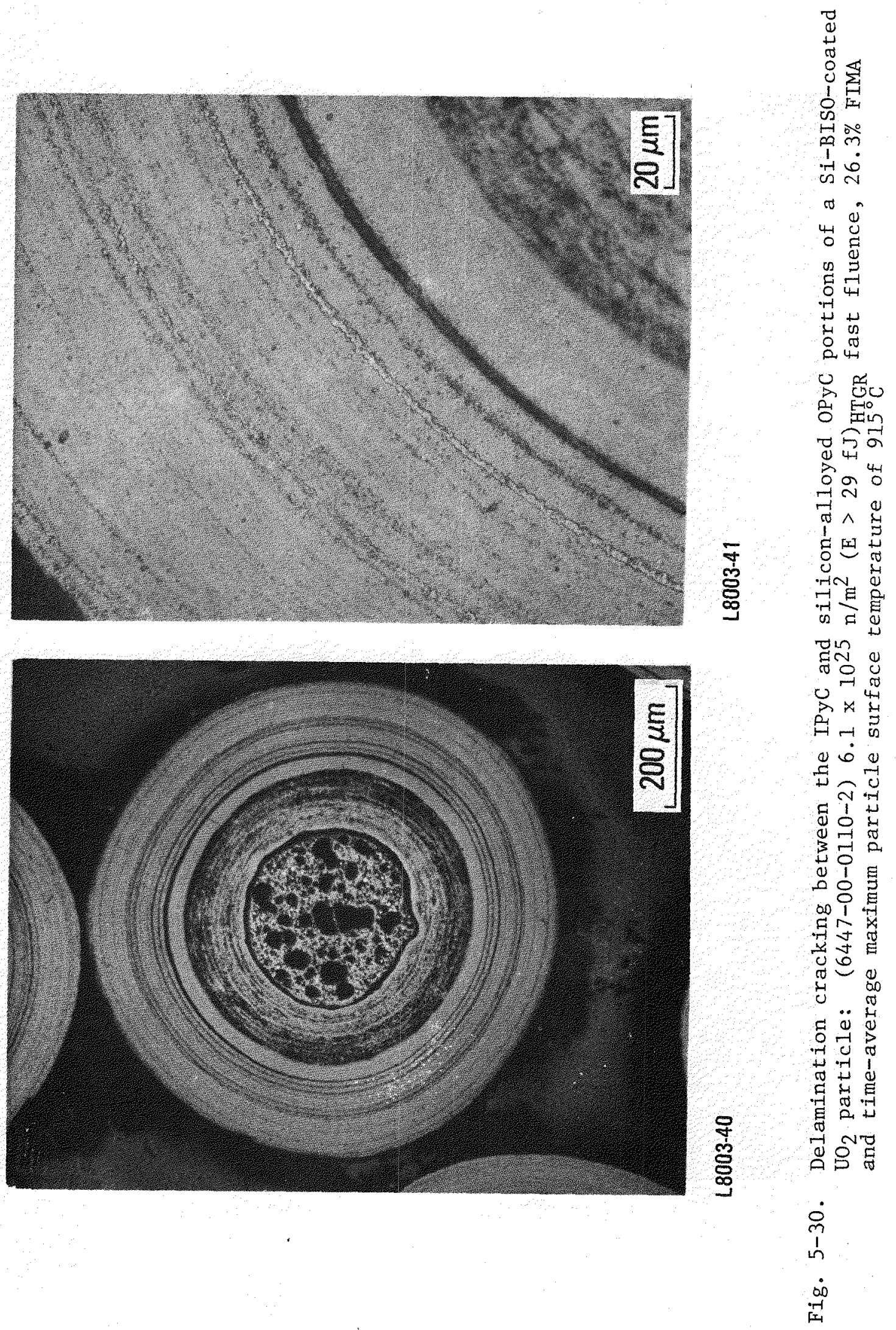


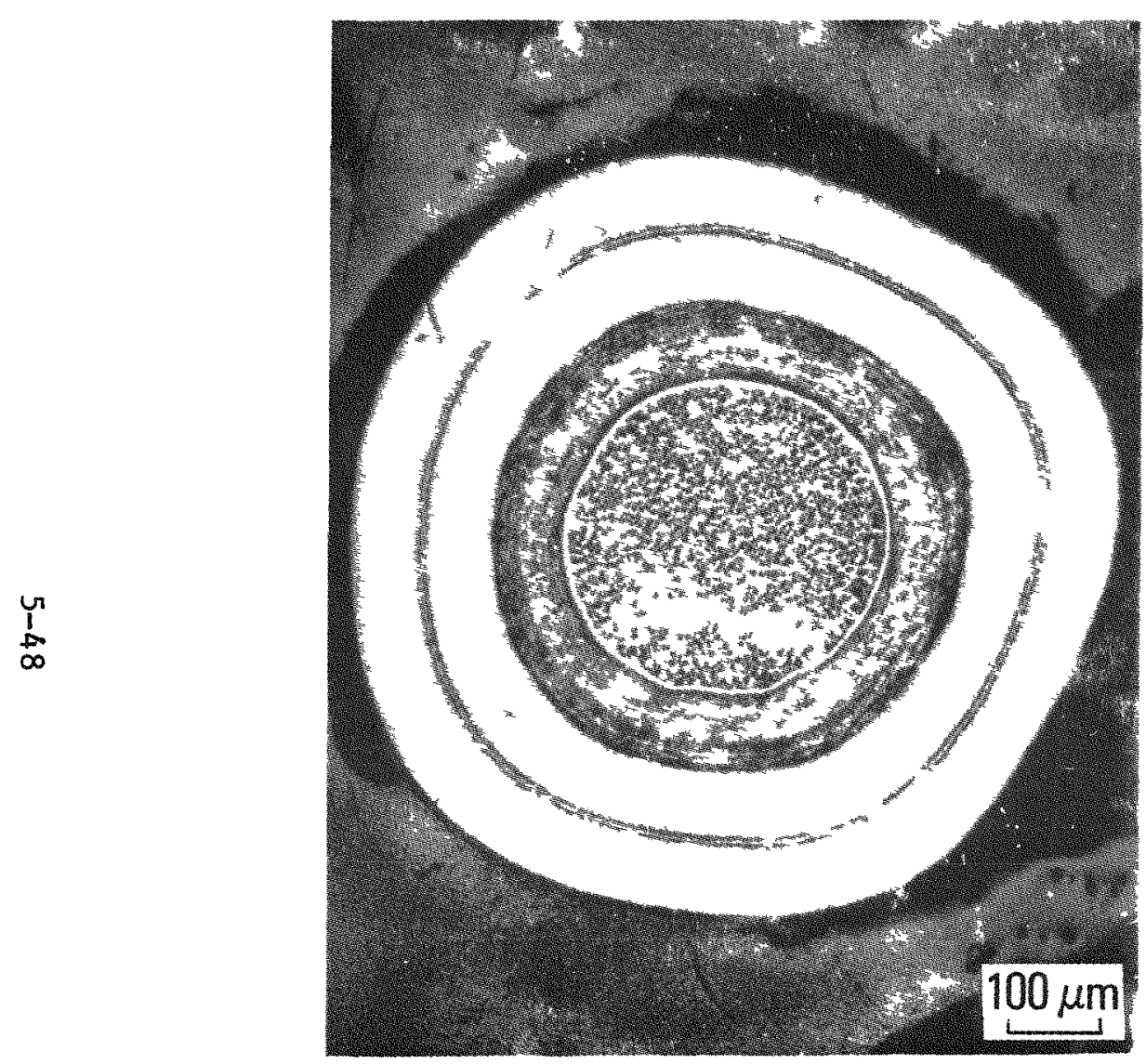

L8003-45

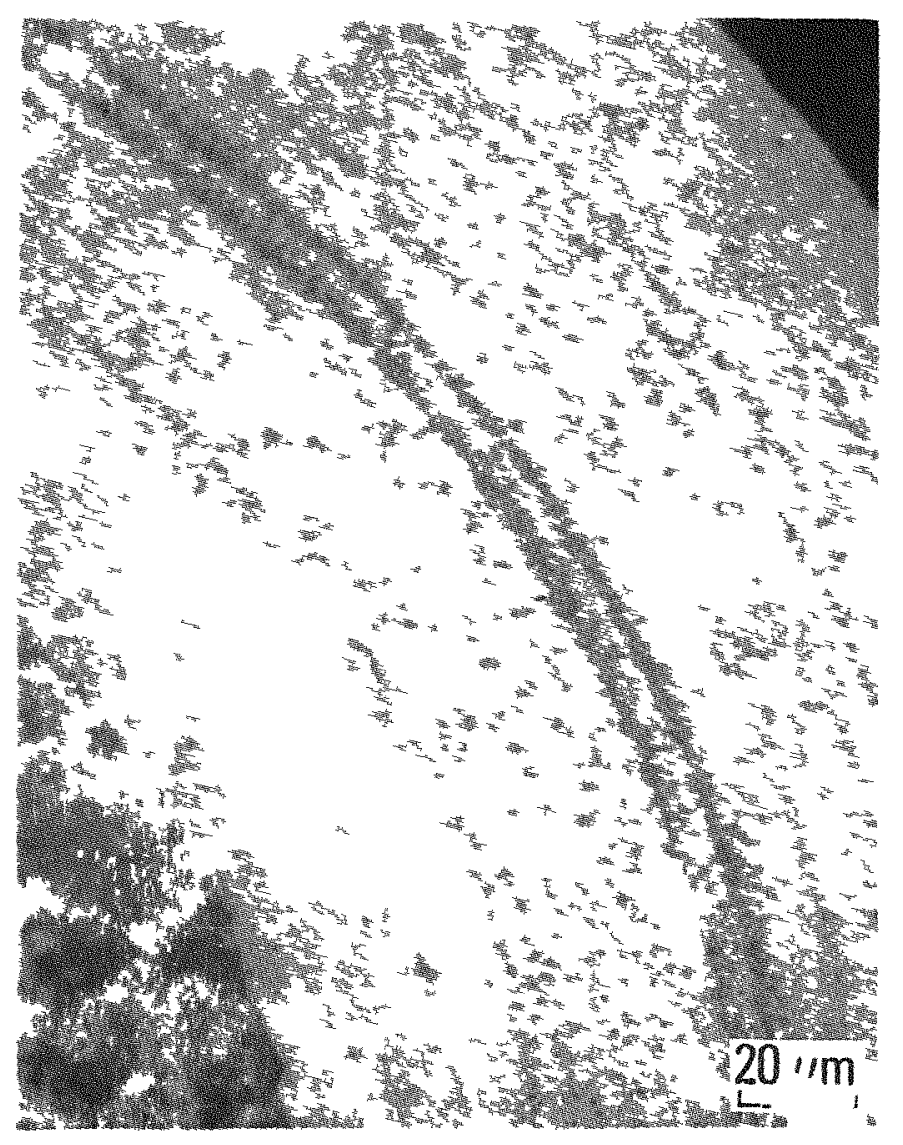

$\mathbf{L} 800348$

Fig. 5-31. Demarcation lines caused by bands of higher porosity in the silicon-alloyed coating on a UCO Si-BISO particle: (6448-00-0110-1) $6.4 \times 10^{25} \mathrm{n} / \mathrm{m}^{2}$ (E > $29 \mathrm{fJ}$ ) HTGR fast fluence, 26.1\% FIMA and time-average maximum particle surface temperature of $905^{\circ} \mathrm{C}$ 


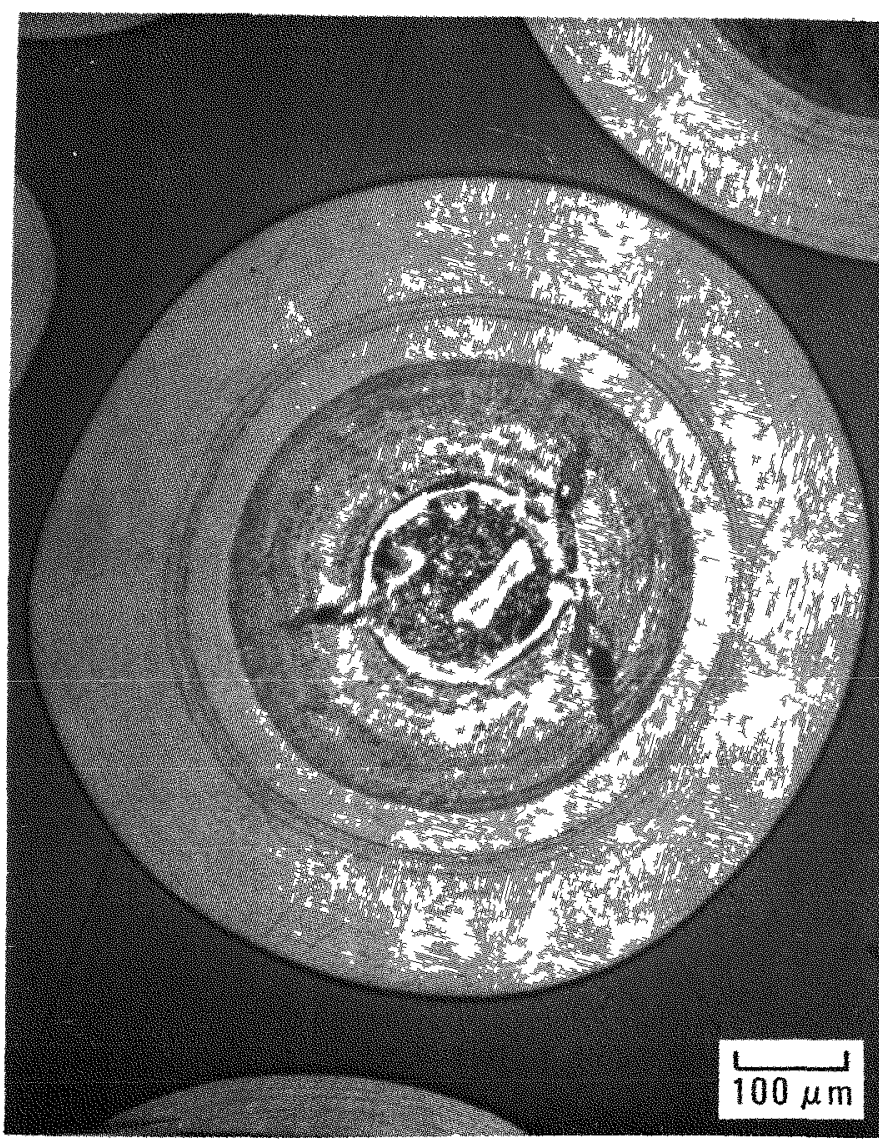

L7925-115

(a)

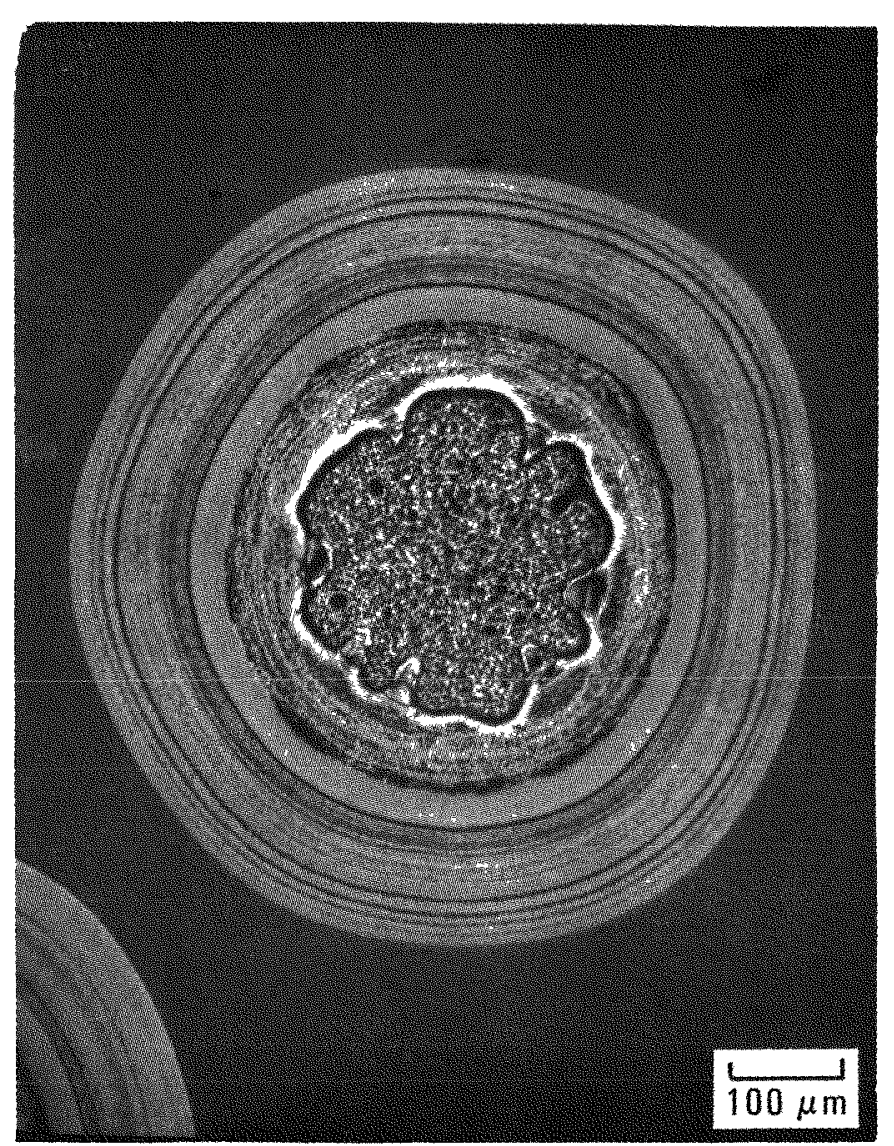

L8003-16

(b)

Fig. 5-32. Irradiation damage to the inner buffer layer in silicon-alloyed UO 2 BISO particles: (a) a $5 \mathrm{\mu m} \mathrm{ZrC} \mathrm{layer} \mathrm{around} \mathrm{the} \mathrm{kernel} \mathrm{(6447-02-0110-1),} 4.8 \times 10^{25} \mathrm{n} / \mathrm{m}^{2}$ (E $>29 \mathrm{fJ}$ ) HTGR fast fluence, 22.5\% FIMA and time-average maximum particle surface temperature of $860^{\circ} \mathrm{C}$ and (b) $\mathrm{ZrC}$ dispersed throughout the buffer layer $(6447-01-0110-2), 4.5 \times 10^{25} \mathrm{n} / \mathrm{m}^{2}(\mathrm{E}>29 \mathrm{fJ})$ HTGR fast fluence, $23.6 \%$ FIMA and time-average maximum particle surface temperature of $915^{\circ} \mathrm{C}$ 


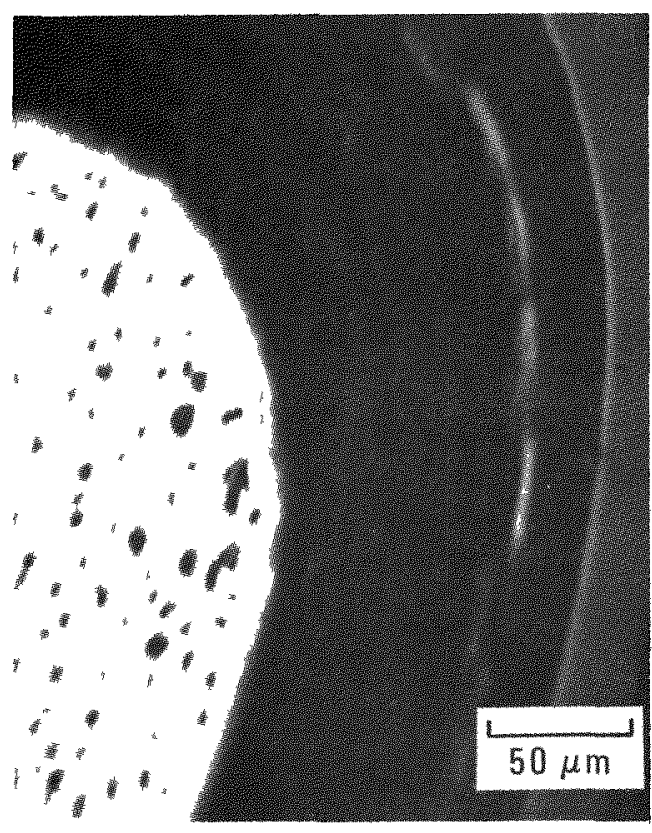

(a)

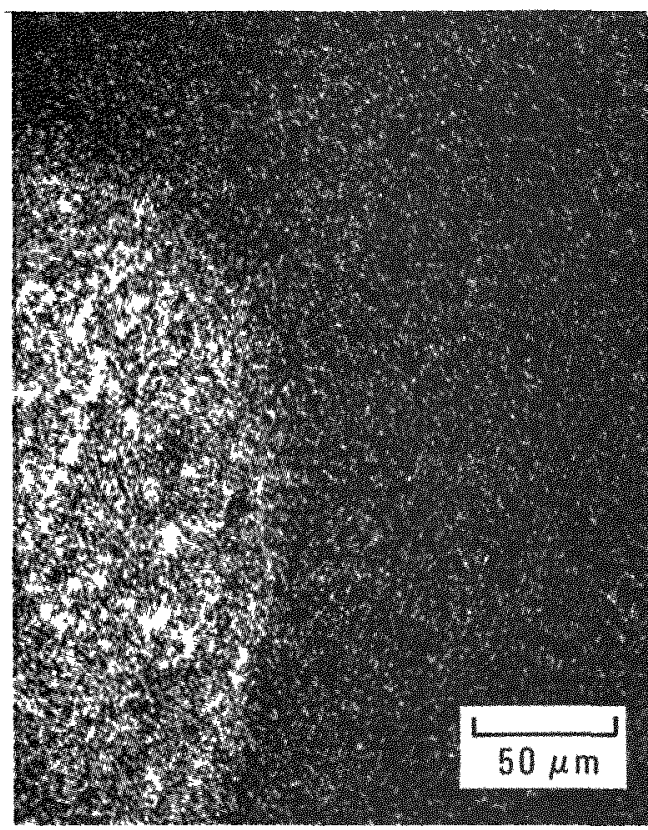

(c)

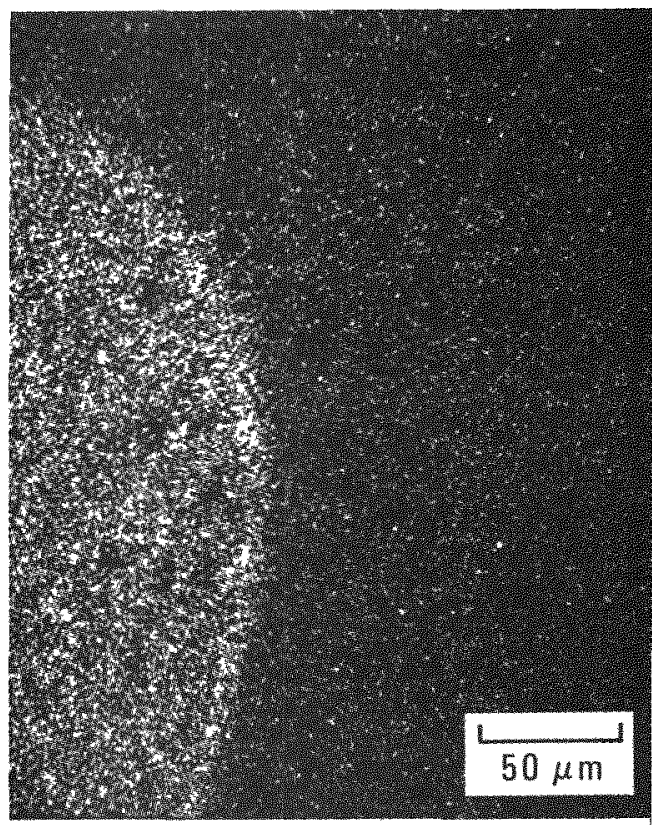

(b)

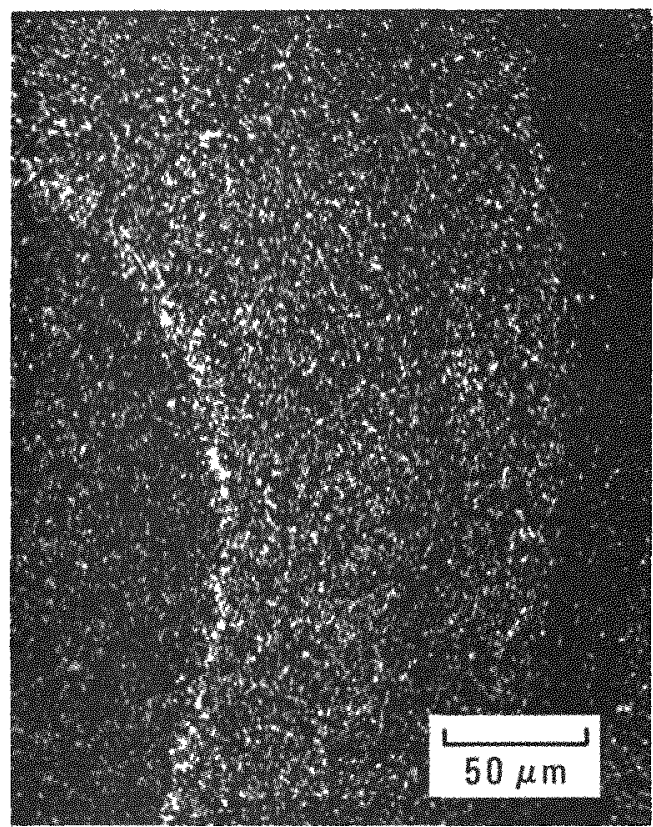

(d)

Fig. 5-33. Electron microprobe photos of a $\mathrm{UC}_{0.2} 0_{1}, 6$ TRISO particle (6157-09-0120-3) irradiated to $6.5 \times 1025 \mathrm{n} / \mathrm{m}^{2}$ (E > $\left.29 \mathrm{fJ}\right)_{\mathrm{HTGR}}$, 26.5\% FIMA and time-average maximum particle surface temperature of $905^{\circ} \mathrm{C}$ : (a) back-scattered electron image, (b) $\mathrm{Zr} \mathrm{L \alpha}$, (c) $\mathrm{Pd}$ $\mathrm{L} \alpha$, and (d) Cs $\mathrm{L} \alpha$ 


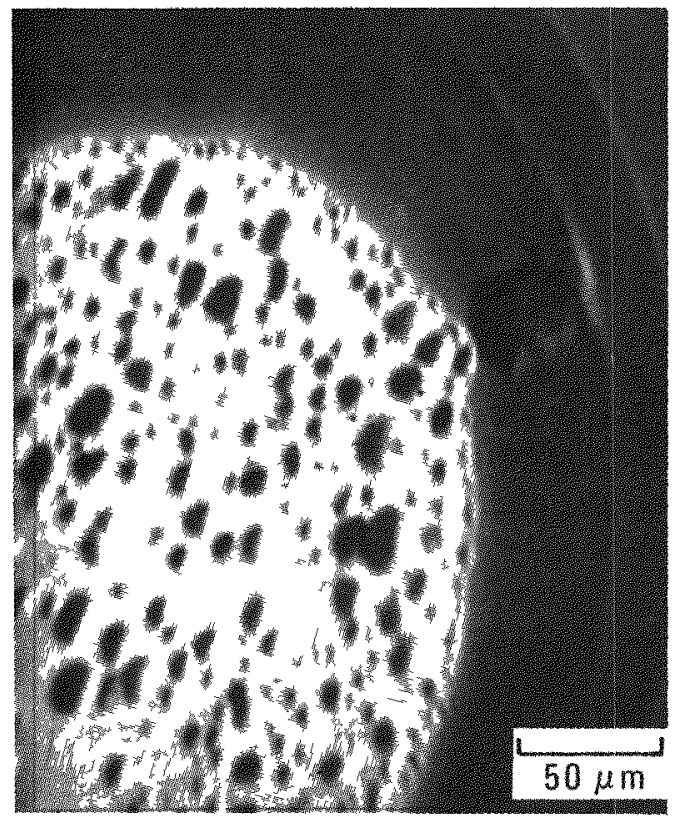

(a)

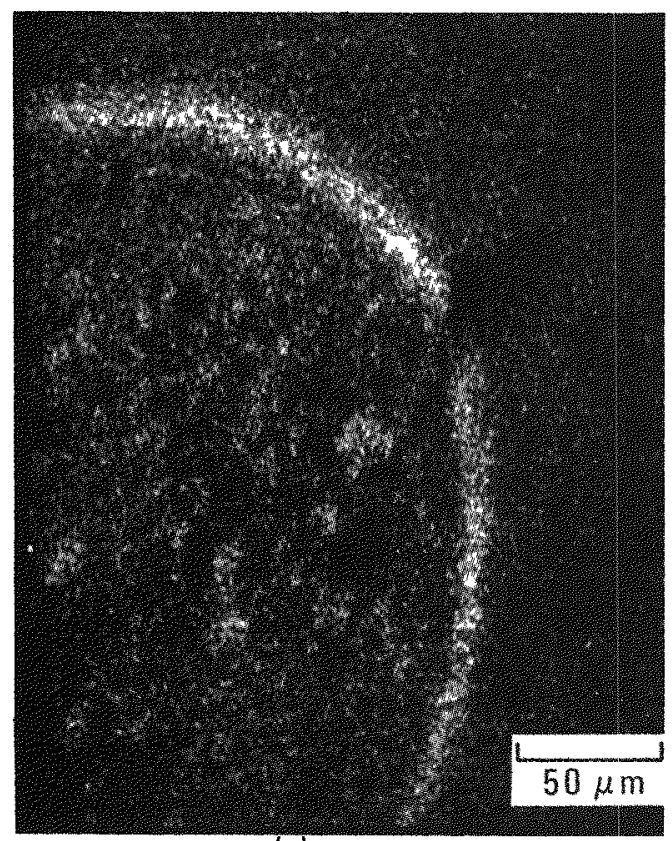

(c)

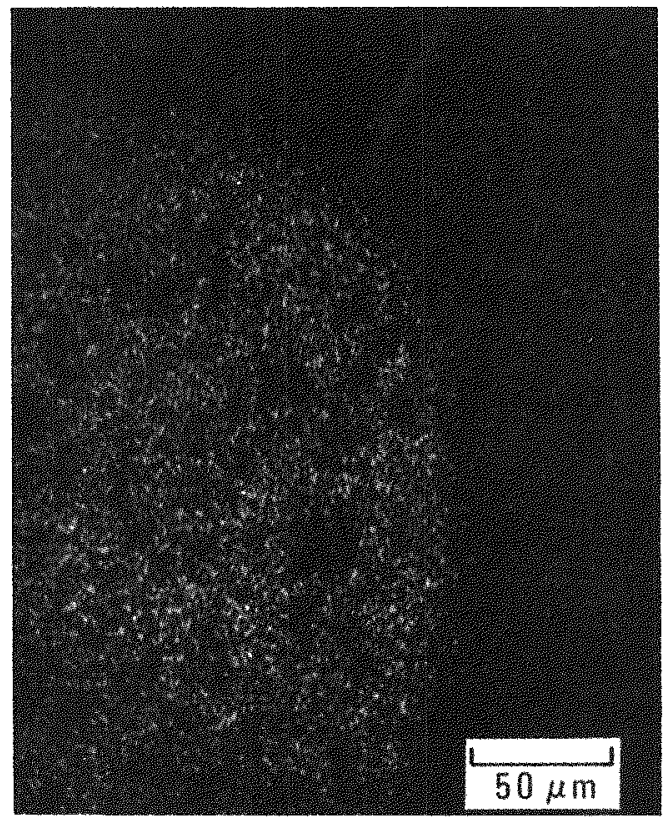

(b)

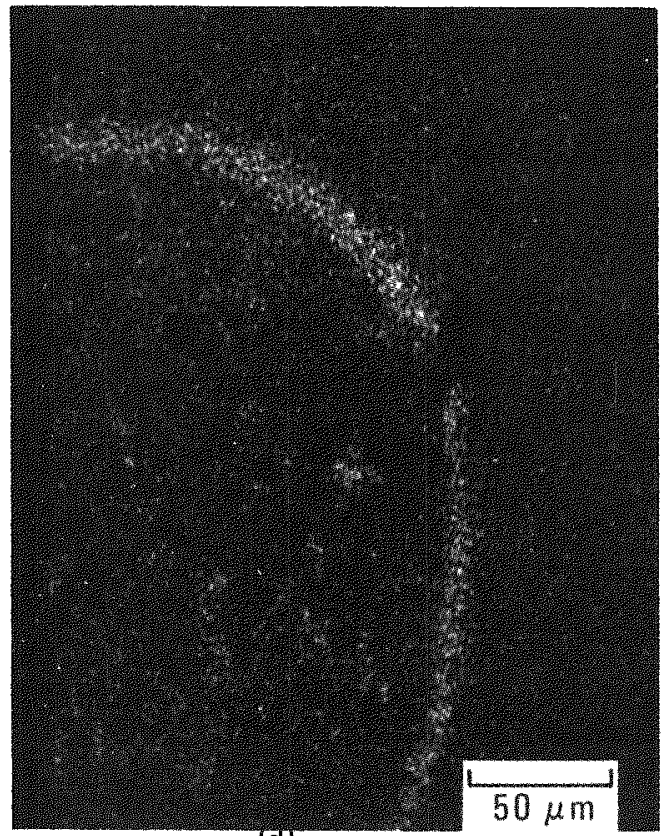

(d)

Fig. 5-34. Electron microprobe photos of a UC 2 TRISO particle (6151-21$0111-3$ ) irradiated to $6.6 \times 10^{25} \mathrm{n} / \mathrm{m}^{2}$ (E > $\left.29 \mathrm{fJ}\right)_{\text {HTGR }}, 26.6 \%$ FIMA and time-average maximum particle surface temperature of $905^{\circ} \mathrm{C}$. (a) back-scattered electron image, (b) $\mathrm{Ru} L \alpha$, (c) $\mathrm{Nd}$ $\mathrm{L} \alpha$, and (d) Ce L $\alpha$ 


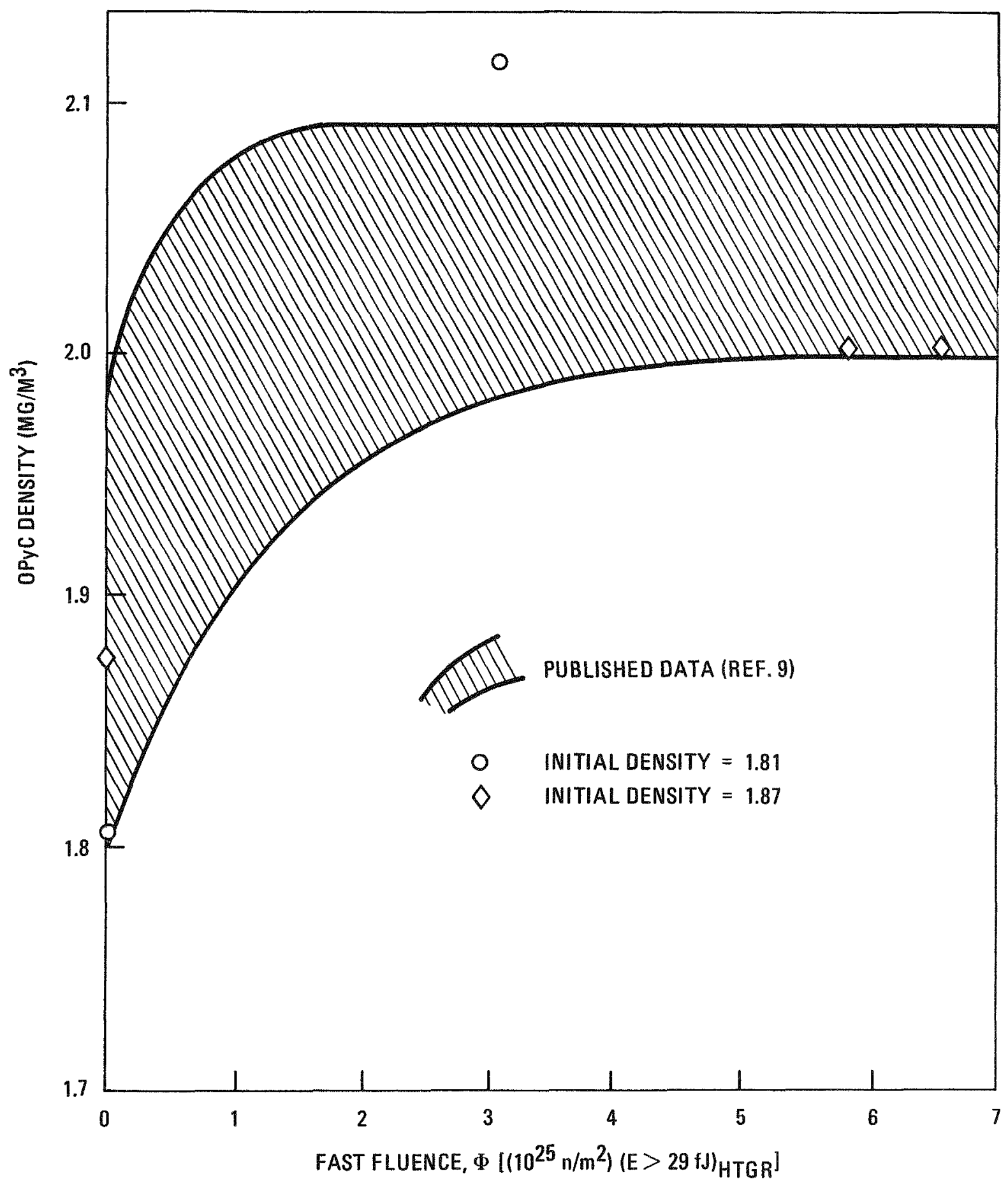

Fig. 5-35. Comparison of measured OPyC density change for standard OPyC coatings from HRB-15B TRISO particles versus published data (Ref. 9). Irradiation temperature was $2900^{\circ} \mathrm{C}$. 


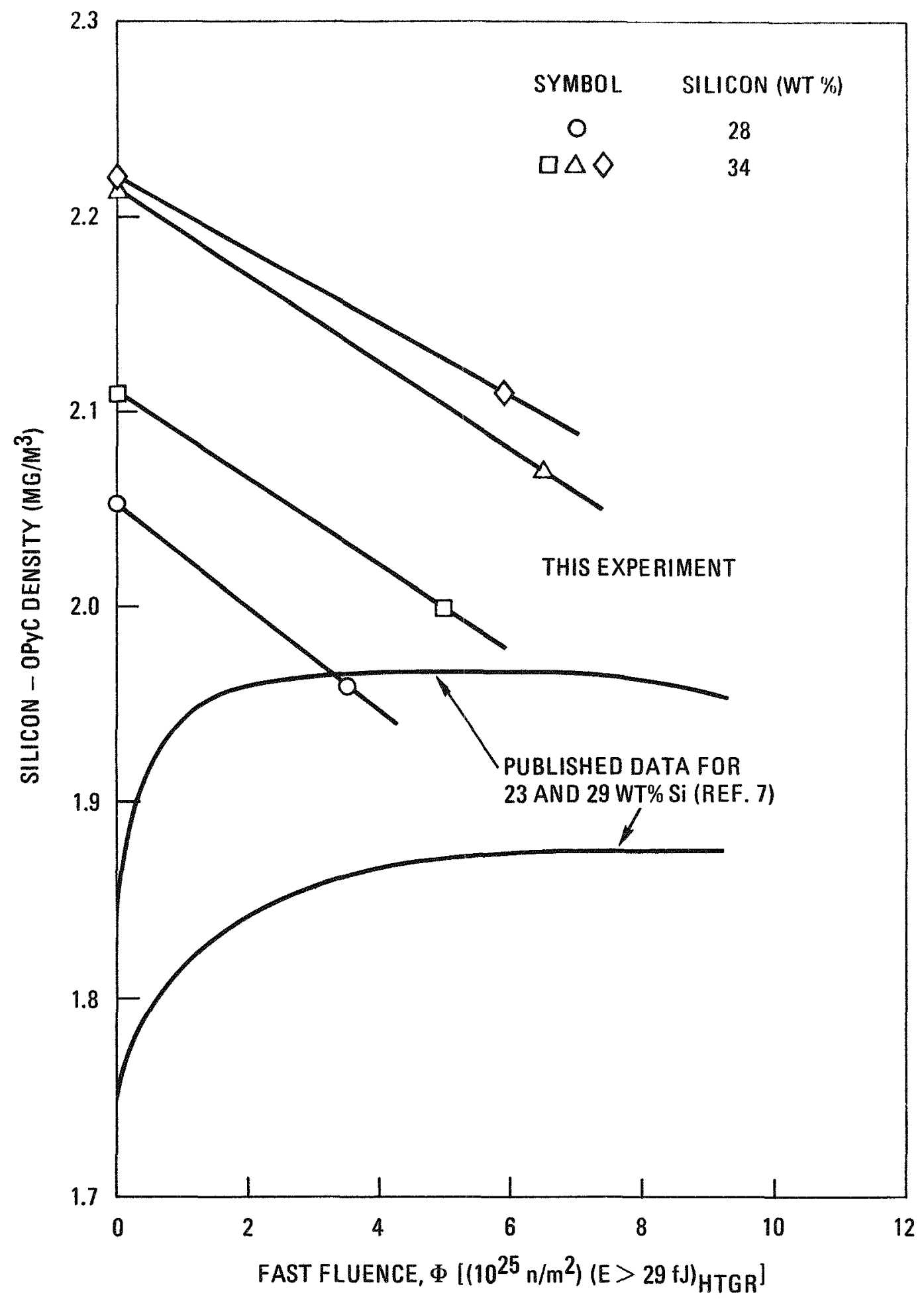

Fig. 5-36. Measured silicon-OPyC density change versus fluence for four $\mathrm{HRB}-15 \mathrm{~B}$ samples and published values for unrestrained siliconOPyC. Irradiation temperatures for all cases were $\sim 850^{\circ} \mathrm{C}$. 
TABLE 5-1

FAILURE FRACTIONS OF GA TRISO-COATED INERT PARTICLES TESTED IN HRB-15B

\begin{tabular}{|c|c|c|c|c|c|c|c|c|c|c|}
\hline \multirow{3}{*}{$\begin{array}{c}\text { Particle } \\
\text { Designation } \\
\text { and } \\
\text { Batch No. }\end{array}$} & \multicolumn{10}{|c|}{ Particle Location and Fast Fluence, $\Phi\left[\left(\mathrm{n} / \mathrm{m}^{2}\right)(\mathrm{E}>29 \mathrm{fJ})_{\mathrm{HTGR}}\right]$} \\
\hline & \multicolumn{3}{|c|}{ Spine 1} & \multicolumn{2}{|c|}{ Spine 2} & \multicolumn{3}{|c|}{ Spine 3} & \multicolumn{2}{|c|}{ Spine 4} \\
\hline & 4.0 & $\begin{array}{l}\text { Top } \\
\times 10^{25}\end{array}$ & $\begin{array}{c}\text { Bot tom } \\
5.1 \times 10^{25}\end{array}$ & $\begin{array}{c}\text { Top } \\
6.1 \times 10^{25} \\
\end{array}$ & $\begin{array}{c}\text { Bottom } \\
6.5 \times 10^{25} \\
\end{array}$ & 6.4 & $\begin{array}{l}\text { Top } \\
\times \quad 10^{25}\end{array}$ & $\begin{array}{c}\text { Bottom } \\
5.9 \times 10^{25} \\
\end{array}$ & $4.7 \times 10^{\text {Top }}$ & $\begin{array}{c}\text { Bottom } \\
3.6 \times 10^{25} \\
\end{array}$ \\
\hline $\begin{array}{c}\text { A } \\
\text { (Smal1 PyC) } \\
6351-05-010\end{array}$ & $3 / 106$ & $=0.03^{(a)}$ & -- & -- & -- & $10 / 80$ & $=0.13$ & -- & -- & - \\
\hline $\begin{array}{c}\text { D } \\
\text { (Large PyC) } \\
6351-05-040\end{array}$ & & -- & -- & -- & $13 / 62=0.21$ & & - & -- & -- & $7 / 63=0.11$ \\
\hline $\begin{array}{l}{ }^{B} \\
\text { (Sma11 Si/PyC) } \\
6351-05-020\end{array}$ & & -- & $5 / 101=0.05$ & -- & -- & & -- & $7 / 64=0.11$ & - & -- \\
\hline $\begin{array}{c}\mathrm{E} \\
\text { (Large } \mathrm{Si} / \mathrm{PyC}) \\
6351-05-050\end{array}$ & & -- & -- & $13 / 62=0.21$ & - & & -- & -- & $7 / 61=0.11$ & -- \\
\hline \begin{tabular}{l}
\multicolumn{1}{c}{$c$} \\
(Anisotropic) \\
6351-05-030
\end{tabular} & $18 / 60$ & $=0.30$ & -- & $43 / 43=1.00$ & -- & $35 / 35$ & $=1.00$ & - & $47 / 47=1.00$ & - \\
\hline $\begin{array}{c}F \\
\text { (Isotropic) } \\
6351-05-060\end{array}$ & & - & Lost & -- & $4 / 32=0.125$ & & -- & $4 / 31=0.13$ & - & $2 / 32=0.06$ \\
\hline
\end{tabular}

(a) $3 / 106$ means 3 of the 106 particles examined had failed, giving a failure fraction of 0.03 . 
TABLE 5-2

DIMENSIONAL CHANGE OF HRB-15B GRAPHITE TRAYS

\begin{tabular}{|c|c|c|c|c|c|c|}
\hline \multirow{2}{*}{$\begin{array}{l}\text { Tray } \\
\text { No. }\end{array}$} & \multirow{2}{*}{$\begin{array}{c}\text { Preirradiation } \\
\text { Measurements } \\
{[\mathrm{cm}(\text { in.) }]}\end{array}$} & \multicolumn{3}{|c|}{$\begin{array}{c}\text { Postirradiation } \\
\text { Measurements } \\
{[\mathrm{cm}(\text { in.) }]}\end{array}$} & \multirow{2}{*}{$\begin{array}{c}\text { Diameter } \\
\text { Change, } \\
\Delta \mathrm{D} / \mathrm{D}_{\mathrm{O}} \\
(\%)\end{array}$} & \multirow{2}{*}{$\begin{array}{l}\text { Fast Fiuence, } \\
\Phi\left[\left(10^{25} \mathrm{n} / \mathrm{m}^{2}\right)\right. \\
\left.(\mathrm{E}<29 \mathrm{fJ})_{\mathrm{HTGR}}\right]\end{array}$} \\
\hline & & 0 deg & $90 \mathrm{deg}$ & Average & & \\
\hline 5 & $2.232(0.8786)$ & $2.240(0.8820)$ & $2.241(0.8823)$ & $2.241(0.8822)$ & 0.41 & 3.6 \\
\hline 6 & $2.232(0.8786)$ & $2.240(0.8820)$ & $2.241(0.8823)$ & $2.241(0.8822)$ & 0.41 & 3.7 \\
\hline 14 & $2.277(0.8963)$ & $2.291(0.9018)$ & $2.289(0.9010)$ & $2.290(0.9014)$ & 0.57 & 4.1 \\
\hline 31 & $2.327(0.9163)$ & $2.342(0.9221)$ & $2.344(0.9230)$ & $2.343(0.9226)$ & 0.69 & 5.0 \\
\hline 48 & $2.341(0.9215)$ & $2.363(0.9305)$ & $2.358(0.9282)$ & $2.361(0.9294)$ & 0.86 & 5.7 \\
\hline 76 & $2.360(0.9292)$ & $2.382(0.9377)$ & $2.382(0.9376)$ & $2.382(0.9377)$ & 0.91 & 6.5 \\
\hline 77 & $2.360(0.9292)$ & $2.382(0.9378)$ & $2.380(0.9372)$ & $2.381(0.9375)$ & 0.89 & 6.5 \\
\hline 84 & $2.360(0.9291)$ & $2.387(0.9396)$ & $2.386(0.9393)$ & $2.386(0.9395)$ & 1.11 & 6.5 \\
\hline 100 & $2.360(0.9293)$ & $2.386(0.9393)$ & $2.386(0.9392)$ & $2.386(0.9393)$ & 1.08 & 6.5 \\
\hline 108 & $2.361(0.9297)$ & $2.385(0.9388)$ & $2.385(0.9388)$ & $2.385(0.9388)$ & 0.98 & 6.4 \\
\hline 146 & $2.327(0.9162)$ & $2.350(0.9252)$ & $2.348(0.9243)$ & $2.350(0.9248)$ & 0.94 & 5.0 \\
\hline 158 & $2.307(0.9081)$ & $2.325(0.9155)$ & $2.330(0.9172)$ & $2.328(0.9164)$ & 0.91 & 4.4 \\
\hline 168 & $2.276(0.8961)$ & $2.296(0.9040)$ & $2.295(0.9036)$ & $2.296(0.9038)$ & 0.86 & 3.8 \\
\hline 176 & $2.277(0.8963)$ & $2.293(0.9029)$ & $2.295(0.9035)$ & $2.294(0.9032)$ & 0.77 & 3.4 \\
\hline
\end{tabular}


TABLE 5-3

COMPARISON OF GA PARTICLE BATCH VISUAL EXAM RESULTS WITH PARTICLE TRAY AUTORADIOGRAPHIC OBSERVATIONS (a)

\begin{tabular}{|c|c|c|c|c|c|}
\hline $\begin{array}{l}\text { Holder } \\
\text { No. }\end{array}$ & $\begin{array}{l}\text { Tray } \\
\text { No. }\end{array}$ & $\begin{array}{l}\text { Kernel } \\
\text { Type }\end{array}$ & $\begin{array}{l}\text { Coating } \\
\text { Type }\end{array}$ & Visual Exam with Particles in Trays & Autoradiograph \\
\hline 1 & 2 & $(\mathrm{Th}, \mathrm{U}) \mathrm{O}_{2}$ & Si-BISO & One crushed particle ${ }^{(b)}$ & $\begin{array}{l}\text { So much activity from tray No. } 2 \\
\text { that film is completely over- } \\
\text { exposed }\end{array}$ \\
\hline 1 & 15 & $\mathrm{ThO}_{2}$ & TRISO & $\begin{array}{l}\text { B1ack spots on } \sim 12 \text { particles, no crushed } \\
\text { or broken ones }\end{array}$ & $\begin{array}{l}\text { Some activity indicated but not } \\
\text { good, distinct pattern }\end{array}$ \\
\hline 1 & 20 & $\mathrm{vC}_{2}$ & Si-BISO & Two crushed particles & $\begin{array}{l}\text { One large and one small bright } \\
\text { spot seen }\end{array}$ \\
\hline 5 & 38 & $\mathrm{UC}_{2}$ & TRISO & Eight crushed particles, broken tray & Completely overexposed film \\
\hline 5 & 54 & $(\mathrm{Th}, \mathrm{U}) \mathrm{O}_{2}$ & TRISO & Three crushed particles, two in one place & $\begin{array}{l}\text { One large and one small bright } \\
\text { spot in right location }\end{array}$ \\
\hline 5 & 58 & $(\mathrm{Th}, \mathrm{U}) \mathrm{O}_{2}$ & TRISO & $\begin{array}{l}\text { Four crushed particles, three in one } \\
\text { place, one alone }\end{array}$ & $\begin{array}{l}\text { Two bright spots; one large and } \\
\text { one small }\end{array}$ \\
\hline 5 & 62 & $(\mathrm{Th}, \mathrm{U}) \mathrm{O}_{2}$ & TRISO & $\begin{array}{l}\text { Three crushed particles, two together, one } \\
\text { alone }\end{array}$ & $\begin{array}{l}\text { Two bright spots; one large and } \\
\text { one small }\end{array}$ \\
\hline 6 & 141 & $\mathrm{ThO}_{2}$ & Si-BISO & $\begin{array}{l}\text { Al1 particles in place, no failure } \\
\text { observed }\end{array}$ & $\begin{array}{l}\text { Completely overexposed; must } \\
\text { still be a particle in the tray }\end{array}$ \\
\hline 6 & $\begin{array}{l}150 \\
152\end{array}$ & $\begin{array}{l}\text { vCo } \\
\text { UCO }\end{array}$ & $\begin{array}{l}\text { TRISO } \\
\text { TRISO }\end{array}$ & $\begin{array}{l}\text { Holder No. } 6 \text { was the one that the lid } \\
\text { came loose on during shipment; } \\
\text { particles were spilled and broken }\end{array}$ & $\begin{array}{l}\text { One large, bright spot; many } \\
\text { smaller spots like debris }\end{array}$ \\
\hline 6 & 66 & $(\mathrm{Th}, \mathrm{U}) \mathrm{O}_{2}$ & TRISO & No particle damage observed & $\begin{array}{l}\text { Bottom of tray showed a faint } \\
\text { pattern; tray No. } 67 \text { had } \mathrm{ThO}_{2} \\
\text { St-BISO and showed release }\end{array}$ \\
\hline 8 & 80 & vCo & TRISO & Two crushed particles close together & $\begin{array}{l}\text { Two small, bright spots close } \\
\text { together }\end{array}$ \\
\hline 8 & 67 & $\mathrm{ThO}_{2}$ & $\mathrm{Si}-\mathrm{BISO}$ & No particle damage observed & $\begin{array}{l}\text { Distinct hole pattern evident } \\
\text { on this tray and bottom of } \\
\text { tray No. } 66\end{array}$ \\
\hline 8 & 81 & $\mathrm{ThO}_{2}$ & Si-BISO & No particle damage observed & $\begin{array}{l}\text { Distinct hole pattern evident } \\
\text { here and on bottom of tray No. } 80\end{array}$ \\
\hline 8 & 70 & $\mathrm{vo}_{2}^{*}$ & Si-BISO & No particle damage observed & $\begin{array}{l}\text { Distinct pattern seen but only on } \\
\text { one area of the tray ( } \sim 12 \text { holes })\end{array}$ \\
\hline 10 & 97 & $\mathrm{ThO}_{2}$ & BISO & No particle damage observed & Several bright holes observed \\
\hline 10 & 94 & $(\mathrm{Th}, \mathrm{U}) \mathrm{O}_{2}$ & TRISO & No particle damage observed & $\begin{array}{l}\text { Debris-1ike spots seen on bottom } \\
\text { of this tray (tray No. } 95 \text { was } \\
\text { ORNL) }\end{array}$ \\
\hline 11 & 135 & $\mathrm{ThO}_{2}$ & $\begin{array}{l}\text { BISO } \\
\text { (ORNL) }\end{array}$ & Not visually examined & $\begin{array}{l}\text { Tray was bright all over with a } \\
\text { few distinct bright spots }\end{array}$ \\
\hline 12 & 103 & $\mathrm{ThO}_{2}$ & Si-BISO & No particle damage observed & $\begin{array}{l}\text { One big, bright spot on tray as } \\
\text { if one particle were stuck in a } \\
\text { hole }\end{array}$ \\
\hline 12 & 108 & UCo & TRISO & No particle damage observed & $\begin{array}{l}\text { Very faint pattern on the top of } \\
\text { this tray }\end{array}$ \\
\hline 13 & 121 & $\mathrm{ThO}_{2}$ & BISO & No particle damage observed & $\begin{array}{l}\text { Quite a bit of activity on this } \\
\text { tray but not a distinct pattern } \\
\text { seen }\end{array}$ \\
\hline 13 & 118 & $\mathrm{UO}_{2}$ & Si-BISO & No particle damage observed & $\begin{array}{l}\text { Activity seen in one area of tray } \\
\text { but not a distinct pattern }\end{array}$ \\
\hline 14 & 156 & $\mathrm{vo}_{2}^{*}$ & Si-BISO & No particle damage observed & $\begin{array}{l}\text { Clear hole pattern seen; three } \\
\text { full rings and partly full fourth } \\
\text { ring }\end{array}$ \\
\hline 14 & 158 & $\mathrm{vC}_{2}$ & Si-BISO & No particle damage observed & $\begin{array}{l}\text { Bright, clear hole pattern; can } \\
\text { count } 72 \text { holes }\end{array}$ \\
\hline
\end{tabular}

(a) Particle trays not listed in this table showed no significant activity on the autoradiograph.

(b) Crushed here refers to damage incurred during capsule disassembly and is not an irradiation effect. See Section 5.1 for more details. 
TABLE 5-4

RESULTS OF METALLOGRAPHIC EXAMINATION ON GA TRISO-COATED ThO $2,1: 1$ (Th, U) $0_{2}$, AND UC $\mathrm{C}_{\mathrm{X}} \mathrm{O}_{\mathrm{Y}}$ TESTED IN HRB-15B $\mathrm{B}^{(\mathrm{a})}$

\begin{tabular}{|c|c|c|c|c|c|c|c|c|c|c|c|}
\hline \multirow[b]{2}{*}{$\begin{array}{l}\text { Tray } \\
\text { No. }\end{array}$} & \multirow[b]{2}{*}{$\begin{array}{c}\text { Kerne } 1 \\
\text { Type }\end{array}$} & \multirow[b]{2}{*}{$\begin{array}{c}\text { Kernel } \\
\text { Burnup } \\
(\% \text { FIMA })\end{array}$} & \multirow[b]{2}{*}{$\begin{array}{c}\text { Fast Fluence, } \\
\Phi\left[\left(10^{25} \mathrm{n} / \mathrm{m}^{2}\right)\right. \\
\left.(\mathrm{E}<29 \mathrm{fJ})_{\text {HTGR }}\right]\end{array}$} & \multirow{2}{*}{$\begin{array}{l}\text { Time- } \\
\text { Average } \\
\text { Maximum } \\
\text { Particle } \\
\text { Surface } \\
\text { Temp }\left({ }^{\circ} \mathrm{C}\right)\end{array}$} & \multirow[b]{2}{*}{$\begin{array}{l}\text { Buffer-IPyC } \\
\text { Separation }\end{array}$} & \multirow{2}{*}{$\begin{array}{l}\text { Kernel } \\
\text { Extrusion } \\
\text { Into } \\
\text { Buffer } \\
\text { Cracks }\end{array}$} & \multicolumn{2}{|c|}{ Buffer Layer } & \multicolumn{3}{|c|}{ SiC Layer ${ }^{(b)}$} \\
\hline & & & & & & & Cracked & $\begin{array}{l}\text { Densified } \\
\text { Area Around } \\
\text { Kernel }\end{array}$ & $\begin{array}{l}\text { Short, } \\
\text { Lenticular } \\
\text { Flaws }\end{array}$ & $\begin{array}{l}\text { Porosity in } \\
\text { Inner Half } \\
\text { of Layer }\end{array}$ & $\begin{array}{l}\text { Fine Porosity } \\
\text { Disbursed } \\
\text { Throughout } \\
\text { (c) }\end{array}$ \\
\hline 71 & $\mathrm{ThO}_{2}$ & 5.7 & 6.4 & 860 & $19 / 21^{(d)}$ & $0 / 21$ & $0 / 21$ & $21 / 21$ & $1 / 21$ & $21 . / 21$ & $0 / 21$ \\
\hline 8 & $1: 1(\mathrm{Th}, \mathrm{U}) \mathrm{O}_{2}$ & 11.1 & 3.8 & 840 & $10 / 18$ & $0 / 18$ & $0 / 18$ & $\mathrm{x}$ & $0 / 18$ & $x$ & $0 / 18$ \\
\hline 92 & $1: 1(\mathrm{Th}, \mathrm{U}) \mathrm{O}_{2}$ & 16.4 & 6.6 & 885 & $0 / 19$ & $0 / 19$ & $0 / 19$ & $\mathrm{x}$ & $2 / 19$ & $19 / 19$ & $0 / 19$ \\
\hline 166 & $\mathrm{UC}_{2}$ & 22.5 & 3,9 & 915 & $\mathrm{x}$ & $0 / 20$ & $0 / 20$ & $\mathrm{x}$ & $0 / 20$ & $0 / 20$ & $0 / 20$ \\
\hline 90 & $\mathrm{uC}_{2}$ & 26.6 & 6.6 & 905 & $\mathrm{x}$ & $\mathrm{x}$ & $\mathrm{x}$ & $\mathrm{x}$ & $0 / 20$ & $0 / 20$ & Slight \\
\hline 18 & $\mathrm{vC}_{0.700 .5}$ & 21.2 & 4.3 & 860 & $21 / 21$ & $x$ & $\mathrm{x}$ & $\mathrm{x}$ & $0 / 21$ & $0 / 21$ & $\mathrm{x}$ \\
\hline 150 & $\mathrm{uC}_{0.700 .5}$ & 24.2 & 4.8 & 915 & $\mathrm{x}$ & $x$ & $1 / 21$ & $x$ & $2 / 21$ & $0 / 21$ & $x$ \\
\hline 12 & $\mathrm{UC}_{0.5 \mathrm{O}_{1.1}}$ & 20.3 & 4.0 & 860 & $5 / 21$ & $\mathrm{x}$ & $0 / 21$ & $\mathrm{x}$ & $0 / 21$ & $0 / 21$ & $\mathrm{x}$ \\
\hline 104 & $\mathrm{UC}_{0.5 \mathrm{O}_{1} .1}$ & 26.6 & 6.4 & 915 & $19 / 21$ & $2 / 21$ & $2 / 21$ & $\mathrm{x}$ & $0 / 21$ & $0 / 21$ & $21 / 21$ \\
\hline 168 & $\mathrm{UC}_{0.2 \mathrm{O}_{1.6}}$ & 22.3 & 3.8 & 915 & $\mathrm{x}$ & $0 / 20$ & $0 / 20$ & $\mathrm{x}$ & $0 / 20$ & $0 / 20$ & Slight \\
\hline 84 & $\mathrm{UC}_{0.201 .6}$ & 26.5 & 6.5 & 905 & $\mathrm{x}$ & $0 / 20$ & $0 / 20$ & $\mathrm{x}$ & $0 / 20$ & $0 / 20$ & Slight \\
\hline
\end{tabular}

(a) $\mathrm{X}$ indicates that the attribute was observed but was not quantified. $19 / 21$ means 19 of the observed attribute out of 21 particles examined. No kernel migration, pressure vessel failures, or irradiation-induced opyC failures were observed in this examination.

(b) Several samples and cracks through the IPyC, SiC, and OPyC layers that were attributed to mount preparation. 
TABLE 5-5

GA PARTICLE SAMPLES TESTED IN HRB-15B SUBMITTED FOR IMGA ANALYSIS AT ORNL

\begin{tabular}{|c|c|c|c|c|c|}
\hline $\begin{array}{l}\text { Tray } \\
\text { No. }\end{array}$ & $\begin{array}{l}\text { Particle } \\
\text { Data Retrieva1 } \\
\text { No. }\end{array}$ & $\begin{array}{c}\text { Kerne1 } \\
\text { Type }\end{array}$ & $\begin{array}{l}\text { Coating } \\
\text { Type }\end{array}$ & $\begin{array}{l}\text { Kernel } \\
\text { Burnup } \\
(\% \text { FIMA })\end{array}$ & $\begin{array}{l}\text { Number of } \\
\text { Particles } \\
\text { Analyzed }\end{array}$ \\
\hline 80 & $6157-08-0320-4$ & $\mathrm{UC}_{0.490_{1.12}}$ & TRISO & 26.4 & 26 \\
\hline 116 & $6448-01-0110-2$ & $\mathrm{UC}_{0.49^{0}} 1.12$ & Si-BISO & 26.4 & 21 \\
\hline 138 & $6152-02-0110-10$ & $\mathrm{UO}_{2}^{*}(\mathrm{a})$ & TRISO & 25.2 & 20 \\
\hline 156 & $6447-01-0110-2$ & $\mathrm{vO}_{2}^{*}(\mathrm{a})$ & Si-BISO & 23.6 & 24 \\
\hline 148 & $6152-01-0120-3$ & $\mathrm{UO}_{2}$ & TRISO & 24.2 & 24 \\
\hline 118 & $6447-00-0110-2$ & $\mathrm{UO}_{2}$ & Si-BISO & 26.3 & 24 \\
\hline 50 & $6155-05-0220-1$ & $(\mathrm{Th} / \mathrm{U}) \mathrm{O}_{2}$ & TRISO & 14.9 & 25 \\
\hline 114 & $6445-01-0110-2$ & $(\mathrm{Th} / \mathrm{U}) \mathrm{O}_{2}$ & Si-BISO & 16.2 & 15 \\
\hline 181 & $6252-15-0131-5$ & $\mathrm{ThO}_{2}$ & TRISO & 2.7 & 25 \\
\hline 67 & $6542-42-0210-5$ & $\mathrm{ThO}_{2}$ & Si-BISO & 5.6 & 25 \\
\hline 77 & $6542-27-0190-4$ & $\mathrm{ThO}_{2}$ & BISO & 5.9 & 25 \\
\hline
\end{tabular}

(a) This particle type had a ZrC-doped buffer layer. 
TABLE 5-6

COMPARISON OF GAMMA-SCAN RESULTS WITH AUTORADIOGRAPHY

OF HRB-15B GRAPHITE TRAYS

\begin{tabular}{|c|c|c|c|c|c|c|}
\hline \multirow{2}{*}{$\begin{array}{l}\text { Tray } \\
\text { No. }\end{array}$} & \multirow{2}{*}{$\begin{array}{c}\text { Kernel } \\
\text { Type }\end{array}$} & \multirow{2}{*}{$\begin{array}{l}\text { Coating } \\
\text { Type }\end{array}$} & \multicolumn{3}{|c|}{$\begin{array}{l}\text { Gamma-Scan Results } \\
(\mu \mathrm{C} \text { / } / \text { sample })\end{array}$} & \multirow{2}{*}{$\begin{array}{l}\text { Significant } \\
\text { Activity seen on } \\
\text { Autoradiography? }\end{array}$} \\
\hline & & & $\mathrm{Cs}-134$ & $\mathrm{Cs}-137$ & $\mathrm{Ag}-110 \mathrm{~m}$ & \\
\hline 96 & $\mathrm{UC}_{2}$ & TRISO & -- & -- & $1.0(27)$ & No \\
\hline 90 & $\mathrm{UC}_{2}$ & TRISO & - & -- & $0.4(52)$ & No \\
\hline 34 & $\mathrm{UC}_{2}$ & TRISO & $0.5(16)$ & -- & $1.1(9.4)$ & No \\
\hline 166 & $\mathrm{UC}_{2}$ & TRISO & $0.2(25)$ & -- & 0 & No \\
\hline 71 & $\mathrm{ThO}_{2}$ & TRISO & $3.5 \quad(5)$ & $0.9(12)$ & 0.9 (18) & No \\
\hline 68 & $\mathrm{UC}_{0.70^{0}} 0.5$ & Si-BISO & $6.3(2.8)$ & $3.6(5.4)$ & $1.0(17)$ & No \\
\hline 70 & $\mathrm{UO}_{2}^{*}$ & Si-BISO & $13.0(1.8)$ & $5.4(3.9)$ & $1.0(15)$ & Yes \\
\hline 158 & $\mathrm{UC}_{2}$ & Si-BISO & -- & -- & $86.0(2.2)$ & Yes \\
\hline 156 & $\mathrm{UO}_{2}^{*}$ & Si-BISO & - & -- & $47.0(29)$ & Yes \\
\hline 67 & $\mathrm{ThO}_{2}$ & Si-BISO & $16.0(1.4)$ & $11(1.5)$ & -- & Yes \\
\hline 81 & $\mathrm{ThO}_{2}$ & Si-BISO & $22.7(1.4)$ & $13.2(1.7)$ & -- & Yes \\
\hline 97 & $\mathrm{ThO}_{2}$ & BISO & $0.63(23)$ & -- & -- & Yes \\
\hline
\end{tabular}

(a) The activities given were back-calculated to the end of the irradiation from the measured values. The numbers in parentheses are the 10 counting errors (percent) for each count. 
PGA RESULTS OF 11 GA PARTICLE BATCHES TESTED IN ARB-15B

\begin{tabular}{|c|c|c|c|c|c|c|c|c|c|c|c|c|}
\hline $\begin{array}{l}\text { Tray } \\
\text { No. }\end{array}$ & Batch No. & $\begin{array}{c}\text { Kerne1 } \\
\text { Type }\end{array}$ & $\begin{array}{l}\text { Coating } \\
\text { Type }\end{array}$ & $\begin{array}{c}\text { Fast Fluence, } \\
\oint\left[\left(10^{25} \mathrm{n} / \mathrm{m}^{2}\right)\right. \\
\left.(\mathrm{E}<29 \mathrm{fJ})_{\mathrm{HTGR}}\right]\end{array}$ & $\begin{array}{l}\text { Kernel } \\
\text { Burnup } \\
\text { (\% FIMA) }\end{array}$ & $\begin{array}{l}\text { Irradiation } \\
\text { Temp } \\
\left({ }^{\circ} \mathrm{C}\right)\end{array}$ & $\sum \operatorname{Kr}(a)$ & $\Sigma \mathrm{Xe}^{(\mathrm{b})}$ & $\begin{array}{l}\text { Total Gas } \\
\text { Measured } \\
\text { (nmoles)(c) }\end{array}$ & $\begin{array}{l}\text { Theoretical } \\
\text { Inventory } \\
\text { (nnoles)(d) }\end{array}$ & $\begin{array}{c}\text { Measured/ } \\
\text { Theoretical } \\
(\%)\end{array}$ & $\begin{array}{c}\text { U/Th } \\
\text { (mg/kernel) }\end{array}$ \\
\hline 12 & $6157-08-0311$ & $\mathrm{uC}_{0.50_{1.1}}$ & TRISO & 4.0 & 20.3 & 860 & 3.89 & 32.32 & 36.21 & 48.8 & 74 & $0.2243 / 0$ \\
\hline 18 & $6157-08-0210$ & $u c_{0.700 .5}$ & TRISO & 4.3 & 21.2 & 860 & 4.14 & 35.26 & 39.40 & 55.0 & 72 & $0.2435 / 0$ \\
\hline 84 & $6157-09-0120$ & $\mathrm{uC}_{0.2 \mathrm{O}_{1.6}}$ & TRISO & 6.5 & 26.5 & 905 & 6.27 & 63.22 & 69.49 & 64.4 & 108 & $0.2310 / 0$ \\
\hline 90 & $6151-21-0111$ & $\mathrm{vc}_{2}$ & TRISO & 6.6 & 26.6 & 905 & 5.83 & 55.59 & 61.42 & 59.7 & 103 & $0.2140 / 0$ \\
\hline 92 & $6155-05-0111$ & $(\mathrm{Th}, \mathrm{U}) \mathrm{O}_{2}$ & TRISO & 6.6 & 16.4 & 885 & 4.27 & 38.16 & 42.43 & 38.3 & 111 & $0.1101 / 0.1059$ \\
\hline 98 & $6152-03-0111$ & $\mathrm{vO}_{2}^{*}(e)$ & TRISO & 6.5 & 26.7 & 915 & 3.84 & 41.05 & 44.89 & 41.3 & 109 & $0.1477 / 0$ \\
\hline 71 & $6252-15-0140$ & $\mathrm{ThO}_{2}$ & TRISO & 6.4 & 5.7 & 860 & 3.53 & 15.83 & 19.36 & 26.9 & 72 & $0 / 0.4270$ \\
\hline 168 & $6157-09-0120$ & $\mathrm{uc}_{0.2^{\mathrm{O}}}{ }_{1.6}$ & TRISO & 3.8 & 22.3 & 915 & 5.69 & 53.15 & 58.84 & 52.9 & 111 & $0.2310 / 0$ \\
\hline 150 & $6157-08-0210$ & $\mathrm{uc}_{0.70_{0.5}}$ & TRISO & 4.8 & 24.2 & 915 & 5.50 & 51.47 & 56.97 & 60.6 & 94 & $0.2436 / 0$ \\
\hline 104 & $6157-08-0320$ & $\mathrm{UC}_{0.5 \mathrm{~S}_{1.1}}$ & TRISO & 6.4 & 26.6 & 905 & 5.80 & 63.27 & 69.07 & 62.2 & 111 & $0.2238 / 0$ \\
\hline 124 & $6152-02-0110$ & $\mathrm{UO}_{2}^{*(f)}$ & TRISO & 5.9 & 26.1 & 915 & 3.10 & 36.19 & 39.29 & 41.6 & 94 & $0.1537 / 0$ \\
\hline
\end{tabular}

(a) Includes $\mathrm{Kr}-83, \mathrm{Kr}-84$, and $\mathrm{Kr}-86$.

(b) Includes Xe-131, Xe-132, Xe-134, and Xe-136.

(c) Average of five particles for each batch.

(d) Calculated using mean kernel loadings for each batch (\% FIMA kernel burnup) and assuming 0.277 krypton and xenon atoms per fissile and 0.271 atoms per fission for the fertile particles.

(e) This particle type had a 5- $\mu \mathrm{m}$ ZrC layer applied to the kerne1.

(f) This particle type had a $\mathrm{zrC}$-doped buffer layer. 
TABLE 5-8

PRE- AND POSTIRRADIATION FISSION GAS RELEASE OF

THREE GA TRISO-COATED PARTICLE TYPES TESTED IN HRB-15B

\begin{tabular}{|c|c|c|c|c|c|}
\hline \multirow[b]{2}{*}{$\begin{array}{l}\text { Tray } \\
\text { No. }\end{array}$} & \multirow[b]{2}{*}{$\begin{array}{l}\text { Kerne1 } \\
\text { Type }\end{array}$} & \multirow[b]{2}{*}{$\begin{array}{l}\text { Coating } \\
\text { Type }\end{array}$} & \multirow{2}{*}{$\begin{array}{l}\quad \begin{array}{c}\text { Number } \\
\quad \text { of }\end{array} \\
\text { Irradiated } \\
\text { Particles } \\
\text { Analyzed }\end{array}$} & \multicolumn{2}{|c|}{$\begin{array}{c}\text { Fission Gas Release(a) } \\
(R / B) \\
\end{array}$} \\
\hline & & & & $\begin{array}{l}\text { Preirradiation } \\
\left(\times 10^{-7}\right)\end{array}$ & $\begin{array}{l}\text { Postirradiation } \\
\quad\left(\mathrm{x} 10^{-6}\right)\end{array}$ \\
\hline 18 & $\mathrm{UC}_{0.7^{\circ}} 0.5$ & TRISO & 18 & 6.1 & 4.0 \\
\hline 166 & $\mathrm{UC}_{2}$ & TRISO & 46 & 5.0 & 2.4 \\
\hline 48 & $(\mathrm{Th}, \mathrm{U}) \mathrm{O}_{2}$ & TRISO & 106 & 8.0 & 1.2 \\
\hline
\end{tabular}

(a) Release/birth rate for $\mathrm{Kr}-85 \mathrm{~m}$ at $1100^{\circ} \mathrm{C}$. 
TABLE 5-9

OPYC DENSITY OF SEVEN GA PARTICLE TYPES TESTED IN HRB-15B

\begin{tabular}{|c|c|c|c|c|c|c|c|}
\hline \multirow{2}{*}{$\begin{array}{l}\text { Tray } \\
\text { No. }\end{array}$} & \multirow[b]{2}{*}{ Batch No. } & \multirow{2}{*}{$\begin{array}{l}\text { Kernel } \\
\text { Type }\end{array}$} & \multirow{2}{*}{$\begin{array}{c}\text { Coating } \\
\text { Type }\end{array}$} & \multirow{2}{*}{$\begin{array}{c}\text { Fast Fluence, } \\
\Phi\left[\left(10^{25} \mathrm{n} / \mathrm{m}^{2}\right)\right. \\
\left.(\mathrm{E}>29 \mathrm{fJ})_{\text {HTGR }}\right]\end{array}$} & \multicolumn{2}{|c|}{ OPyC Density $\left(\mathrm{Mg} / \mathrm{m}^{3}\right)$} & \multirow[b]{2}{*}{ Change $(\%)(a)$} \\
\hline & & & & & Preirradiation & Postirradiation & \\
\hline 181 & $6252-15-0131$ & $\mathrm{ThO}_{2}$ & TRISO & 3.1 & 1.81 & 2.12 & +17 \\
\hline 48 & $6155-05-0120$ & $(\mathrm{Th}, \mathrm{U}) \mathrm{O}_{2}$ & TRISO & 5.7 & 1.87 & 1.99 & +6 \\
\hline 92 & $6155-05-0111$ & $(\mathrm{Th}, \mathrm{U}) \mathrm{O}_{2}$ & TRISO & 6.6 & 1.87 & 2.00 & +7 \\
\hline 2 & $6445-01-0110$ & $(\mathrm{Th}, \mathrm{U}) \mathrm{O}_{2}$ & Si-BISO & 3.4 & 2.05 & 1.96 & -4 \\
\hline 24 & $6447-01-0110$ & $\mathrm{UO}_{2}{ }^{*}$ & Si-BISO & 4.6 & 2.11 & 2.00 & -5 \\
\hline 51 & $6542-42-0210$ & $\mathrm{ThO}_{2}$ & Si-BISO & 5.9 & 2.22 & 2.11 & -5 \\
\hline 81 & $6542-42-0210$ & $\mathrm{ThO}_{2}$ & Si-BISO & 6.5 & 2.22 & 2.07 & -7 \\
\hline
\end{tabular}

(a) $\left[\left(\rho_{\mathrm{f}}-\rho_{\mathrm{O}}\right) / \rho_{\mathrm{O}}\right] \times 100$, where $\rho_{\mathrm{f}}=$ postirradiation density, and $\rho_{\mathrm{O}}=$ preirradiation density. 
TABLE $5-10$

DESCRIPTION OF GA INERT TRISO PARTICLES TESTED IN HRB-15B

\begin{tabular}{|c|c|c|c|c|c|c|}
\hline \multirow[b]{2}{*}{$\begin{array}{l}\text { Particle Components, } \\
\text { Their Properties, and } \\
\text { Deposition Conditions }\end{array}$} & \multicolumn{6}{|c|}{ Particle Description - Designation } \\
\hline & $\begin{array}{c}\text { Smal1 PyC- } \\
\text { A }\end{array}$ & $\begin{array}{l}\text { Large PyC- } \\
\text { D }\end{array}$ & $\begin{array}{l}\text { Small Si/Pyc- } \\
\text { B }\end{array}$ & $\begin{array}{l}\text { Large S1/PyC- } \\
\text { E }\end{array}$ & $\begin{array}{l}\text { Anistropic } \\
\text { Si/PyC- } \\
\text { C }\end{array}$ & $\begin{array}{c}\text { Isotropic } \\
\text { Si/PyC- } \\
\text { F }\end{array}$ \\
\hline Batch No. & $6351-05-010$ & $6351-05-040$ & $6351-05-020$ & $6351-05-050$ & $6351-05-030$ & $6351-050-060$ \\
\hline $\begin{array}{l}\text { Kernel } \\
\text { Composition } \\
\text { Dian ( } \mu \mathrm{m})\end{array}$ & $\begin{array}{l}C \\
450\end{array}$ & $\begin{array}{l}C \\
450\end{array}$ & $\begin{array}{l}C \\
450\end{array}$ & $\begin{array}{l}C \\
450\end{array}$ & $\begin{array}{l}C \\
450\end{array}$ & $\begin{array}{l}C \\
450\end{array}$ \\
\hline $\begin{array}{l}\text { Buffer PyC } \\
\text { Thickness }(\mu m)\end{array}$ & 97 & 97 & 97 & 97 & 97 & 97 \\
\hline $\begin{array}{l}\text { Inner Pyc } \\
\text { Thickness }(\mu \mathrm{m})\end{array}$ & 131 & 240 & 123 & 226 & 120 & 230 \\
\hline $\begin{array}{l}\text { SiC } \\
\text { Thickness }(\mu \mathrm{m}) \\
\text { Density }\left(\mathrm{Mg} / \mathrm{m}^{3}\right)\end{array}$ & $\begin{array}{l}34 \\
3.17\end{array}$ & $\begin{array}{l}48 \\
3.21\end{array}$ & ${ }_{\text {ND }}^{34}(a)$ & $\begin{array}{l}47 \\
3.22\end{array}$ & $\begin{array}{l}36 \\
3.17\end{array}$ & $\begin{array}{l}46 \\
3.22\end{array}$ \\
\hline $\begin{array}{l}\text { Outer Coating } \\
\text { Composition } \\
\text { Carbon (wt \%) } \\
\text { Silicon (wt \%) } \\
\text { Thickness }(\mu \mathrm{m}) \\
\text { Volume }\left(\mathrm{mm}^{3}\right) \\
\text { Density }\left(\mathrm{Mg} / \mathrm{m}^{3}\right) \\
\text { Coating Conditions }\end{array}$ & $\begin{array}{l}100 \\
0 \\
44 \\
0.143 \\
1.90\end{array}$ & $\begin{array}{l}100 \\
0 \\
46 \\
0.232 \\
1.83\end{array}$ & $\begin{array}{l}77 \\
23 \\
40 \\
0.125 \\
2.12\end{array}$ & $\begin{array}{l}76 \\
24 \\
43 \\
0.206 \\
2.08\end{array}$ & $\begin{array}{l}85 \\
15 \\
23 \\
0.069 \\
1.94\end{array}$ & $\begin{array}{l}80 \\
20 \\
37 \\
0.177 \\
2.09\end{array}$ \\
\hline $\begin{array}{l}\text { Temperature }(K) \\
\text { Time }(s) \\
\text { Rate }[\mathrm{m} / \mathrm{Gs}(\mu \mathrm{m} / \mathrm{min})] \\
\text { Gas Flows }(\mathrm{b})\left(\mathrm{m}^{3} / \mathrm{Ms}\right)\end{array}$ & $\begin{array}{l}1558 \\
660 \\
66.7(4.0)\end{array}$ & $\begin{array}{l}1573 \\
696 \\
66.1(4.0)\end{array}$ & $\begin{array}{l}1648 \\
900 \\
44.4(2.7)\end{array}$ & $\begin{array}{l}1648 \\
750 \\
57.3(3.4)\end{array}$ & $\begin{array}{l}1573 \\
804 \\
28.6(1.7)\end{array}$ & $\begin{array}{l}1573 \\
840 \\
44.0(2.6)\end{array}$ \\
\hline $\begin{array}{l}\text { Coating Gases } \\
\mathrm{C}_{3} \mathrm{H}_{6} \\
\mathrm{C}_{2} \mathrm{H}_{2} \\
\text { Helium/silane } \\
\text { Helium Diluent } \\
\text { Total Flow }\end{array}$ & $\begin{array}{l}17.5 \\
8.7 \\
0 \\
99.0 \\
125.2\end{array}$ & $\begin{array}{l}12.2 \\
6.1 \\
0 \\
150.0 \\
168.3\end{array}$ & $\begin{array}{l}6.5 \\
3.3 \\
26.7 \\
47.0 \\
83.5\end{array}$ & $\begin{array}{l}6.5 \\
3.3 \\
26.7 \\
156.0 \\
192.5\end{array}$ & $\begin{array}{l}6.5 \\
3.3 \\
26.7 \\
47.0 \\
83.5\end{array}$ & $\begin{array}{l}6.5 \\
3.3 \\
26.7 \\
156.0 \\
192.5\end{array}$ \\
\hline $\begin{array}{l}\text { Charge Wt }(g) \\
\text { In } \\
\text { Out }\end{array}$ & $\begin{array}{l}52.75 \\
67.15\end{array}$ & $\begin{array}{l}48.00 \\
57.80\end{array}$ & $\begin{array}{l}54.36 \\
68.09\end{array}$ & $\begin{array}{l}50.00 \\
61.40\end{array}$ & $\begin{array}{l}49.00 \\
55.30\end{array}$ & $\begin{array}{l}50.00 \\
59.87\end{array}$ \\
\hline $\begin{array}{l}\text { Total Particle } \\
\text { Diam }(\mu \mathrm{m}) \\
\text { Hg Density }\left(\mathrm{Mg} / \mathrm{m}_{3}\right) \\
\text { Composition }\end{array}$ & $\begin{array}{l}1061 \\
1.95\end{array}$ & $\begin{array}{l}1312 \\
1.97\end{array}$ & $\begin{array}{l}1037 \\
1.97\end{array}$ & $\begin{array}{l}1276 \\
2.00\end{array}$ & $\begin{array}{l}1003 \\
1.98\end{array}$ & $\begin{array}{l}1270 \\
2.02\end{array}$ \\
\hline $\begin{array}{l}\text { Carbon (wt \%) } \\
\text { silicon (wt \%) }\end{array}$ & $\begin{array}{l}80.6 \\
19.7\end{array}$ & $\begin{array}{l}79.9 \\
22.7\end{array}$ & $\begin{array}{l}77.9 \\
24.1\end{array}$ & $\begin{array}{l}75.8 \\
23.2\end{array}$ & $\begin{array}{l}77.5 \\
24.2\end{array}$ & $\begin{array}{l}76.8 \\
20.4\end{array}$ \\
\hline
\end{tabular}

(a) $\mathrm{ND}=$ not determined.

(b) These gases flowed through a 35-mm graphite coating tube that was 229 mm long; the levitated bed of fluidized particles was contained within the coating tube. 
TABLE 5-11

ATTRIBUTE COMPARISON OF DENSITY-SEPARATED BATCHES WITH GA PARENT BATCHES TESTED IN HRB-15B

\begin{tabular}{|c|c|c|c|c|c|c|c|c|c|c|}
\hline \multirow{2}{*}{$\begin{array}{l}\text { Batch } \\
\text { No. (a) }\end{array}$} & \multirow[b]{2}{*}{ Kernel Type } & \multirow{2}{*}{$\begin{array}{c}\text { Kerne1 } \\
\text { Di am } \\
(\mu \mathrm{m})\end{array}$} & \multicolumn{4}{|c|}{$\begin{array}{l}\text { Coating Thickness } \\
(\mu \mathrm{m})\end{array}$} & \multicolumn{2}{|c|}{ Total Particle } & \multirow{2}{*}{$\begin{array}{c}\text { Decrease in } \\
\text { Buffer } \\
\text { Thickness } \\
(\%)\end{array}$} & \multirow{2}{*}{$\begin{array}{c}\text { Increase in } \\
\text { Particle } \\
\text { Density } \\
(\%)\end{array}$} \\
\hline & & & Buffer & IPyC & $\mathrm{SiC}$ & OPyC & $\begin{array}{l}\text { Diam } \\
(\mu \mathrm{m})\end{array}$ & $\begin{array}{l}\text { Density } \\
\left(\mathrm{Mg} / \mathrm{m}^{3}\right)\end{array}$ & & \\
\hline $6155-05-0100$ & $(\mathrm{Th}, \mathrm{U}) \mathrm{O}_{2}$ & 357 & 94 & 34 & 36 & 46 & 760 & 2.83 & - & -- \\
\hline $6155-05-0111$ & $(\mathrm{Th}, \mathrm{U}) \mathrm{O}_{2}$ & 356 & 68 & 34 & 39 & 44 & 726 & 3.02 & 27.7 & 7.0 \\
\hline $6157-08-0300$ & $\mathrm{UC}_{0.490_{1}} 1.12$ & 359 & 123 & 47 & 41 & 44 & 863 & 2.49 & -- & - \\
\hline $6157-08-0311$ & $\mathrm{uC}_{0.49^{\circ}} 1.12$ & 354 & 91 & 47 & 46 & 44 & 810 & 2.69 & 26.0 & 8.0 \\
\hline $6157-09-0100$ & $\mathrm{UC}_{0.20^{0}} 1.64$ & 372 & 136 & 43 & 41 & 42 & 877 & 2.50 & - & - \\
\hline $6157-09-0111$ & $\mathrm{uC}_{0.20^{0}} 1.64$ & 372 & 112 & 43 & 42 & 42 & 850 & 2.60 & 17.7 & 4.2 \\
\hline $6152-01-0100$ & $\mathrm{UO}_{2}$ & 299 & 134 & 41 & 32 & 40 & 769 & 2.37 & -- & -- \\
\hline $6152-01-0111$ & $\mathrm{UO}_{2}$ & 300 & 102 & 41 & 37 & 41 & 742 & 2.55 & 23.9 & 7.8 \\
\hline $6152-03-0100$ & $\mathrm{UO}_{2}^{*}(\mathrm{~b})$ & 312 & 82 & 35 & 37 & 41 & 742 & 2.64 & - & - \\
\hline $6152-03-0111$ & $\mathrm{UO}_{2}^{*(b)}$ & 310 & 66 & 35 & 39 & 41 & 708 & $2 \cdot 71$ & 19.5 & 2.8 \\
\hline $6151-21-0100$ & $\mathrm{UC}_{2}$ & 348 & 121 & 37 & 39 & 50 & 835 & 2.55 & -- & -- \\
\hline $6151-21-0111$ & $\mathrm{UC}_{2}$ & 344 & 89 & 37 & 44 & 50 & 784 & 2.72 & 26.4 & 6.7 \\
\hline $6252-15-0100$ & $\mathrm{ThO}_{2}$ & 456 & 54 & 36 & 38 & 48 & 807 & 3.40 & -- & - \\
\hline $6252-15-0131$ & $\mathrm{ThO}_{2}$ & 453 & 49 & 36 & 38 & 48 & 795 & 3.48 & 9.3 & 2.4 \\
\hline
\end{tabular}

(a) Parent batch is given first, density-separated batch second.

(b) This particle type had a 5-um-thick ZrC layer applied to the kernel. 


\section{DISCUSSION}

Most fuel in capsule $\mathrm{HRB}-15 \mathrm{~B}$ was irradiated at temperatures from $\sim 800^{\circ}$ to $900^{\circ} \mathrm{C}$ and fast neutron exposures less than $6.0 \times 10^{25} \mathrm{n} / \mathrm{m}^{2}$

(E > $29 \mathrm{fJ}$ ) HTGR . This was since much of the irradiated fuel will undergo additional out-of-pile testing over the next few years to support the reference LEU fuel choice and to provide an initial data base in support of LEU fuel performance models. The predictable result was that the fuel in HRB$15 \mathrm{~B}$ was not exposed beyond design levels; consequently, none of the traditional forms of particle damage, such as pressure vessel failure or attack of SiC 1ayers by fission products, were observed in the PIE. Useful performance data were gathered, however, through the variety of PIE procedures and additional calculational techniques performed.

\subsection{RETENTION OF THE VOLATILE METALS CESIUM AND SILVER}

A significant part of the PIE effort for $\mathrm{HRB}-15 \mathrm{~B}$ ws directed at determining to what extent volatile fission metals were retained by the fuel particles. Fission product silver is of particular interest with LEU fue1, because it has a greater yie1d from U-238 than from U-235. This subsection discusses the agreement between several PIE methods used to assess the retention of metallic fission products in the HRB-15B particles. Subsections 6.2 and 6.3 discuss the overall irradiation performance of the TRISO-coated and Si-BISO-coated particles, respectively.

Table 6-1 compares the percent release values for $\mathrm{Ag}-110 \mathrm{~m}$ and $\mathrm{Cs}-137$ derived by three methods. Appendix $C$ details the IMGA work; genera11y, the IMGA indicated no release of $\mathrm{Cs}-137$, but significant 10 ss of $\mathrm{Ag}-110 \mathrm{~m}$ from the particles characterized. Although the IMGA results give no basis for assuming errors beyond the calculated total uncertainties given in 
Appendix C ( $9 \%$ to $15 \%$ for $\mathrm{Cs}-137 / \mathrm{Ru}-106$ and $10 \%$ to $16 \%$ for $\mathrm{Ag}-110 \mathrm{~m} / \mathrm{Ru}-106$ ), some aspects of these results are still unexplained:

1. TRISO particles would be expected to release less fission metals than Si-BISO particles under equivalent irradiation conditions, since the latter lack the SiC barrier coating employed in the TRISO design. Yet, the IMGA results indicated no distinctions between the two particle types in this respect. The preirradiation characterization of the particle batches revealed no abnormal deficiencies in the SiC layers of the TRISO particles that would cause them to be suspect. Also, as Table 6-1 shows, the TRISO particles were not predicted to release $\mathrm{Ag}-110 \mathrm{~m}$ under the $\mathrm{HRB}-15 \mathrm{~B}$ irradiation conditions.

2. If $\sim 30 \%$ of the $\mathrm{Ag}-110 \mathrm{~m}$ inventory escaped from the fuel particles, more silver than found on the particle trays would be expected; yet, the tray gamma-scans found very small amounts of $\mathrm{Ag}-110 \mathrm{~m}$, as shown in Tables 5-6 and 6-1. These findings would be compatible only if the $\mathrm{Ag}-110 \mathrm{~m}$ had diffused easily through the graphite trays and was deposited elsewhere in the capsule. Although a conclusive mass balance of $\mathrm{Ag}-110 \mathrm{~m}$ on all the capsule components would be necessary to verify this, workers at both GA and ORNL do not believe that silver would diffuse so easily through dense POCO graphite at these relatively low temperatures (see Figs. 4-1 through 4-4). Also, if silver diffused through the trays, rather than the distinct hole patterns seen on many of the tray autoradiographs, a smeared activity pattern would have been more likely.

The tray gamma-scans and autoradiography results agreed better with performance model predictions and with relative expectations for the two particle types. As noted from Tables 5-3 and 5-6, only the Si-BISO trays always exhibited activity (on the autoradiographs) with sharp hole images matching the particle loadings, except for tray No. 97, which had 
BISO-ThO 2 particles. No trays which had TRISO particles showed this kind of activity. Because no data on silver transport in Si-PyC were available, the $\mathrm{Ag}-110 \mathrm{~m}$ release from the Si-BISO particles was not predicted; however, as stated previous1y, zero $\mathrm{Ag}-110 \mathrm{~m}$ release was predicted from the TRISO particles under these irradiation conditions. Not all the particle trays were gamma-scanned; however, all were autoradiographed (except the ORNL trays, which all contained $\mathrm{ThO}_{2}$ particles). Several shortcomings of the tray gamma-scan/autoradiography results should be recognized. From only the 12 trays scanned (see Table 5-6), the significant activity seen on the autoradiographs and the presence of either $\mathrm{Ag}-110 \mathrm{~m}$ or $\mathrm{Cs}-137$ cannot be directly correlated. One tray (No. 97) showed some significant activity, but no fission products were found by gamma-scan, while two trays (No. 68 and 71 ) had sizeable quantities of cesium present but no activity pattern upon autoradiography. Of the trays that showed significant autoradiograph patterns, trays No. 67 and 81 had cesium but no silver, while trays No. 156 and 158 had silver but no cesium. Possibly, activity below a threshold level is not seen by autoradiography but is detected by gamma-scan.

Another source of error in this work is that each particle tray served as the lid for the tray directly beneath it. Thus, fission products released from the particles could be deposited on the inner walls of their own tray and on the underside of the tray above. This would mean that the gamma-scan results for each tray could underestimate the amounts of fission products released by the particles in that tray. Of course, this effect could be partially or wholly compensated for by fission products coming from the particles in the tray beneath the one of concern, so that exactly quantifying this error would be difficult. From hole surface area considerations alone, if no other fission products were deposited from neighboring trays, the underestimation of the tray gamma-scans would be $\sim 20 \%$.

In comparing the IMGA and particle tray gamma-scan results, the errors associated with the two methods should also be examined. As shown in Appen$\operatorname{dix} C$, the total $1 \sigma$ uncertainty in the IMGA results is $7 \%$ to $15 \%$ for $\mathrm{Cs}_{\mathrm{S}}-137$ and $10 \%$ to $16 \%$ for $\mathrm{Ag}-110 \mathrm{~m}$, with $\mathrm{Ru}-106$ as the stable isotope. The 
corresponding values for the tray gamma-scanning (assuming the same uncertainty in the calculated fission product inventories as with IMGA) are $13 \%$ to $16 \%$ for $\mathrm{Cs}-137$ and $22 \%$ to $24 \%$ for $\mathrm{Ag}-110 \mathrm{~m}$ (see Appendix D). Even allowing for these errors and the $\sim 20 \%$ underestimation discussed above for the tray gamma scans, the results for the TRISO particles are still incompatible and those for the Si-BISO particles only agree slightly.

\subsection{FISSILE TRISO PARTICLE PERFORMANCE}

Much evidence gathered after the irradiation indicates that al1 TRISOcoated fissile particles tested remained intact and retained virtually all of their fission products except Ag-110m. As Table 6-1 indicates, the several techniques employed to assess fission metal retention show no significant release of cesium from the TRISO particles. The 0 to $8 \% \mathrm{Cs}-137$ release indicated by IMGA is within the total uncertainty on the IMGA results ( $92 \%$ retention $\times 14 \%$ total error for $\mathrm{Cs}-137 / \mathrm{Ru}-106$ ratio $=-13 \% 1 \sigma$ error, $79 \%$ to $105 \%$ retention, or 0 to $21 \%$ loss of $\mathrm{Cs}-137$ possible at the $67 \%$ confidence leve1) and, as such, is not convincing evidence of release by itself.

As discussed in Section 6.1, the IMGA findings for Ag-110m release from the TRISO particles do not agree with the results of other PIE tests or the performance mode1 predictions. While the indicated average $27 \% \mathrm{Ag}-110 \mathrm{~m}$ release using $\mathrm{Ru}-106$ as the stable isotope is two to three times what can be attributed to the total error on the IMGA results, the remaining evidence gathered in this PIE indicates very little release of $\mathrm{Ag}-110 \mathrm{~m}$. The $0.1 \%$ to $0.6 \% \mathrm{Ag}-110 \mathrm{~m}$ found by gamma-scanning several of the empty particle trays, even allowing for large errors associated with gamma-counting very small amounts of $\mathrm{Ag}-110 \mathrm{~m}$, cannot be reconciled with the IMGA results unless the silver freely diffused out of the graphite. This is not expected at these relatively low temperatures. Also, although the irradiation conditions were not identical, Dragon data on LEU-TRISO particles agrees well with the contention of 1ittle $\mathrm{Ag}-110 \mathrm{~m}$ release. After $4000 \mathrm{~h}$, LEU-UO ${ }_{2}$-TRISO particles irradiated at $1000^{\circ} \mathrm{C}$ showed $\sim 0.1 \%$ release of $\mathrm{Ag}-110 \mathrm{~m}$ (Ref. 11). Such sma11 amounts of $\mathrm{Ag}-110 \mathrm{~m}$ release, even at these low temperatures, is not 
unexpected, since silver can apparently permeate completely intact SiC layers under certain conditions. While the exact mechanism whereby this release takes place is not yet understood, optimization of the microstructure of the $\mathrm{SiC}$ is believed to be necessary to minimize the release of this volatile fission metal from LEU-TRISO particles.

Thus, the authors contend that the evidence gathered during this PIE will not support a $\mathrm{Ag}-110 \mathrm{~m}$ release level greater than $1 \%$ from the $\mathrm{HRB}-15 \mathrm{~B}$ fissile TRISO particles.

As for all other detectable fission products in the fissile TRISO particles examined, the PGA analysis indicated that the gases xenon and krypton were retained in the particles; no significant activity was seen in the autoradiography or gamma-scans of the particle trays; the microprobe analysis showed no nuclides beyond the buffer layers of these particles. Fission gas release measurements on three fissile TRISO samples had low $\left(10^{-6}\right)$ release of $\mathrm{Kr}-85 \mathrm{~m}$ at $1100^{\circ} \mathrm{C}$.

\subsection{SILICON BISO-COATED PARTICLE PERFORMANCE}

The findings of this PIE indicate that the Si-BISO particles, including fissile and fertile types, released more cesium and silver than the TRISO particles. Distinct activity patterns seen on the autoradiographs of several trays that had contained Si-BISO particles exactly matched the loading patterns of the fuel particles in those trays. Gamma-scans of the empty Si-BISO trays also revealed significant quantities of cesium and silver. Comparing the amounts found on the trays with theoretical end-of-life inventories of these fission products (CURIE calculated) gives release values of $0.04 \%$ and $0.05 \%$ for $\mathrm{Cs}-137$ from $\mathrm{UC}_{0.700 .5}$ and $\mathrm{UO}_{2}^{*}$ with a $\mathrm{ZrC}$ layer, respectively; $2 \%$ and $13 \%$ for $\mathrm{Ag}-110 \mathrm{~m}$ from $\mathrm{UC}_{2}$ and $\mathrm{UO}_{2}^{*}$ with a $\mathrm{ZrC}$-doped buffer, respectively; and $0.12 \%$ and $0.17 \%$ for $\mathrm{Cs}-137$ from $\mathrm{ThO}_{2}$ particles, all with Si-BISO coatings. Table 6-1 also shows the fissile particle results in the Si-BISO columns. 
Concerning cesium release from the fissile Si-BISO particles, much of the discussion in Section 6.2 on the TRISO particles applies equally we11 here. No cesium release was predicted using current performance models; no significant amounts were found in the IMGA work or in the tray gamma-scans (the $0.04 \%$ to $0.05 \%$ cesium release detected from the $\mathrm{UC}_{0} .70_{0.5}$ and $\mathrm{UO}_{2}^{*} \mathrm{Si}-$ BISO samples is near the minimum detectable range for the equipment). Significant quantities of cesium were found, however, on two graphite trays that had held $\mathrm{ThO}_{2}$ Si-BISO particles (trays No. 67 and 81 , Table 5-6). The amounts found were $0.12 \%$ and $0.17 \%$, respectively, of the calculated theoretical inventories. This indicated release from the $\mathrm{ThO}_{2}$ Si-BISO particles is unexpected, particularly since a standard BISO-ThO 2 sample in tray No. 97 at a similar exposure level exhibited no detectable release when the empty particle tray was gamma-scaned, and it showed only slight activity when autoradiographed. Visual exam of these $\mathrm{Si-BISO}-\mathrm{ThO}_{2}$ particles did not indicate failed or otherwise defective outer coatings. In addition, the important OPyC parameters of thickness, density, coating rate, and weight percent silicon for these particles were not significantly different from the nominal

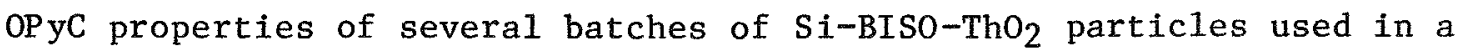
series of postirradiation cesium release experiments, which showed improved cesium retention compared to the reference $\mathrm{BISO-coated} \mathrm{ThO}_{2}$ particle (Ref. 12). As discussed in Section 6.1 , cross-contamination between adjacent particle trays during irradiation was possible. Gamma-scans of every particle tray that could verify this, however, were not done during this PIE. Correlating these observations with $\mathrm{ThO}_{2}$ performance model predictions would be useful to further develop fission product transport models, but is beyond the scope of this report.

Regarding silver retention in the fissile Si-BISO particles in $H R B-15 B$, no performance mode1 prediction was available because of a lack of data on silver transport in $\mathrm{Si}-\mathrm{PyC}$. IMGA results indicated $23 \%$ to $32 \% \mathrm{Ag}-110 \mathrm{~m} 10 \mathrm{ss}$ from these particles, while the tray gamma-scans revealed $2 \%$ to $13 \%$ of the theoretica1 $\mathrm{Ag}-110 \mathrm{~m}$ inventories deposited on the empty trays. In contrast to the TRISO gamma-scan results, the tray gamma-scan and IMGA data for fissile Si-BISO particles agree somewhat if the total uncertainties on the two 
techniques are considered. Why the two gamma-scans with the Si-BISO particles agree better than gamma-scans with TRISO particles is not known. The tray gamma-scan results are recognized to be based on relatively few particle tray measurements, and the IMGA results, as discussed in section 6.1, are not without suspicion. Thus, saying that silver release ranging from 0 to $30 \%$ from the fissile Si-BISO particles in $\mathrm{HRB}-15 \mathrm{~B}$ seems reasonable, based on the PIE results. While quantitative release fractions for this particle type have not been predicted, these results are not unexpected for the SiBISO particle performance relative to the TRISO particle performance, since the former lacks the discrete SiC barrier to fission metals.

\subsection{UC $\mathrm{UC}_{\mathrm{X}} \mathrm{O}_{\mathrm{Y}}$ KERNELS WITH DIFFERENT O/U RATIOS}

$\mathrm{HRB}-15 \mathrm{~B}$ tested four different $\mathrm{UC}_{\mathrm{x}} \mathrm{O}_{\mathrm{y}}$ kernel types to explore possible performance differences with varying $0 / U$ ratios from 0.5 to 1.6 . No pressure vessel performance differences were identified among these samples, and no kernel migration or fission product buildup was observed in the metallography of the $\mathrm{UC}_{\mathrm{x}} \mathrm{O}_{\mathrm{y}}$ types in $\mathrm{HRB}-15 \mathrm{~B}$. However, SiC fission product attack was seen in low-oxygen $\mathrm{UC}_{0.70^{\circ}} 0.5$ TRISO particles irradiated at $\sim 1250^{\circ} \mathrm{C}$ in HRB-14 (Ref. 3), suggesting that differences may exist under more severe conditions.

\subsection{POCO GRAPHITE DIMENSIONAL CHANGE}

Graphite dimensional change rates are important in the design and thermal analysis of irradition tests, because critical temperature control gaps greatly influence fuel temperatures. POCO AFX-9Q graphite was used for the subassemblies in $\mathrm{HRB}-15 \mathrm{~B}$, and the design of the components was based on a graphite dimensional change function shown in Fig. 6-1. This curve is only a general relationship for POCO dimensional change with fluence and does not account for irradiation temperature or variations among different grades of graphite (Ref. 2). Thus, a checking procedure run during the irradiation plotted the dimensional change value that allowed calculated capsule temperatures to match thermocouple temperatures. Figure 6-1 also 
shows these data and the actual measured dimensional changes of graphite trays that were given in Fig. 5-10. Because not all factors are accounted for in these calculations (no data exist for fluence dependence of the coefficient of thermal expansion in POCO, for example, and the graphite trays are assumed to remain circular and centered within the primary containment), the best-fit-to-experiment data do not exactly agree with the measured va1ues. However, the same trend and relative magnitude are apparent. For the measured data in Fig. 6-1, the temperature effect mentioned in Section 5.3 has been emphasized, showing that even the $50^{\circ} \mathrm{C}$ temperature difference between subassembly 1 and the others had a significant effect on the dimensional change of this graphite. These measured values are consistent with the limited irradiation data on POCO graphites, indicating that grades AFX$5 Q$ and $A F X-8 Q$ are nearly stable when irradiated at $1000^{\circ} \mathrm{C}$ to a peak fast fluence of $\sim 6.5 \times 10^{25} \mathrm{n} / \mathrm{m}^{2}$ ( $\mathrm{E}>29 \mathrm{fJ}$ ) $\mathrm{HTGR}$ and expand with fluence at lower irradiation temperatures (Ref. 13). The difference between the design curve and actual measured dimensional change of the POCO trays shown in Fig. 6-1 did not affect fuel particle temperatures in $\mathrm{HRB}-15 \mathrm{~B}$ because of the capsule design. As mentioned in Section 4, the thermocouples directly indicated tray temperatures with no intervening gas gaps, so temperature could be controlled throughout the test without regard for the tray to primary containment gap size. This is not the case, however, with conventional HRB capsules that utilize a graphite sleeve. In the conventional design, fuel sample temperatures are calculated on the basis of an assumed gas gap size, and deviations from assumed dimensional change rates will cause errors in the calculated temperatures. Thus, the dimensional change behavior of the graphite is important to know. Data of this type will be accumulated for several irradiation tests under varied exposure levels to quantify this relationship and reduce uncertainties in future thermal analyses. 


\subsection{SIZE EFFECT ON INERT TRISO PARTICLES}

Capsule HRB-15B irradiated two sizes of inert TRISO particles having similar outer coatings, consisting of both standard PyC (particles A and D) and a silicon-alloyed PyC (particles $B$ and E). The first four column of Table 5-10 describe these two pairs of test particles and give deposition conditions for their outer coatings that were being tested. Particle sizes were controlled by varying the thickness of the IPyC 1ayer; this layer was roughly twice as thick for the larger 1300- $\mu \mathrm{m}$ particle of both test pairs than for the smaller 1050- $\mu \mathrm{m}$ particle. Other coating thicknesses were roughly comparable for all particles. The last two columns of Table 5-10 describe a third set of particles ( $C$ and $F$ ) in which outer coatings were not sufficiently similar to permit size comparisons on failure rates. The coating rate for the smaller $C$ particle fell below the critical value of $33 \mathrm{~m} / \mathrm{Gs}$ (2 $\mu \mathrm{m} / \mathrm{min}$ ) during fabrication, and this is known to produce an anisotropic coating that is subject to large irradiation-induced shrinkages. While this third set of particles could not be used to judge size effects, it was included in the test to obtain additional information on the influence of coating rate on particle failure.

Table 5-1 gives failure statistics for the different inert particles and average neutron-fluence values for the various sample locations. Figure 6-2 plots these data for the two different sizes of particles having similar coatings of standard PyC (A and D) and of silicon-alloyed PyC ( $B$ and E) as a function of fluence, and the wide range of fluence involved is observed to significantly affect coating failure. Failure fractions of the larger size particles for each of the coating types ( $D$ and $E$ ) are also considerably higher than for the smaller particles of the test pairs (A and $B$ ), with factors of difference ranging from about two to four over the fluence range. Thus, a very definite size effect appears to be present in the irradiation performance of the coated particles, with failure rates running at least

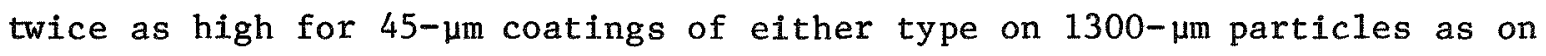
1050- $\mu \mathrm{m}$ particles. 
Any inert particle failure strongly argues in favor of a size effect, because coating failure was essentially zero over the full-fluence range investigated for nominal 850- $\mu \mathrm{m}$ fueled TRISO particles of many different types that were irradiated along with the inert particles in capsule HRB15B. Using these additional data, Fig. 6-3 plots coating failure as a function of particle size for a common fluence of $5.5 \times 10^{25} \mathrm{n} / \mathrm{m}^{2}$, and the strong increase of failure with particle size is readily apparent.

To illustrate the extreme sensitivity of coating failure to deposition conditions within certain critical ranges, Fig. 6-4 plots coating failures for the third pair of test particles ( $C$ and $F$ ) in which the smaller particle was known to be coated at a rate that produces anisotropic coatings subject to large irradiation-induced shrinkages. The failure curve for the larger $\mathrm{F}$ particle that was coated at an acceptable rate agrees reasonably well with curves $\mathrm{D}$ and $\mathrm{E}$ of $\mathrm{Fig}$. 6-3 for similar sized particles in those test pairs. However, the failure curve for the anisotropic $\mathrm{C}$ particle increases rapidly with fluence to reach $100 \%$, and based on size effects alone, this curve for the smaller particle should fall below the larger particle curve of Fig. 6-4, as do the $A$ and $B$ curves in Fig. 6-3. Thus, the coating-rate variable causes an order-of-magnitude upward shift in the failure rate of particle $\mathrm{C}$ compared to the similar-sized A and B particles of Fig. 6-3, whereas the size effect itself only causes failure to roughly double over the size range studied. This illustrates the necessity to carefully control deposition conditions in studies on particle size effects.

\subsection{DENSITY-SEPARATED TRISO-PARTICLE BATCHES}

Density-separated samples from seven TRISO parent batches were included in $H R B-15 B$ as part of on-going pressure vessel performance model studies. The parent batches had first been characterized for total particle density using a representative split sample, then approximately the upper $10 \%$ portion was separated out for inclusion in the capsule. These highest density particles represented the portions of the parent batches made with the highest probability of failure by the pressure vessel mode. Table 5-11 gives 
the attributes of the parent and density-separated portions of the seven batches and shows the percent difference in the buffer thicknesses for each particle type. Little failure (maximum of $1.1 \%$ at peak capsule fluence) was predicted with the TRISO*MONTE design computer code [failure assumed when the SiC stress reaches $-23.23 \mathrm{MPa}(-3400 \mathrm{psi})]$, and no pressure vessel failures were observed in any of the density-separated batches during the PIE. Higher failure would have been predicted at higher levels of exposure and temperature. A few of these particles seen in the metallographic examination had no buffer layers and, from all indications, were still completely intact. The information gained from this work, while not identifying specific performance limits, indicates that the particle designs tested are extremely reliable and conservative from a pressure vessel standpoint at the exposure levels encountered in this capsule. 


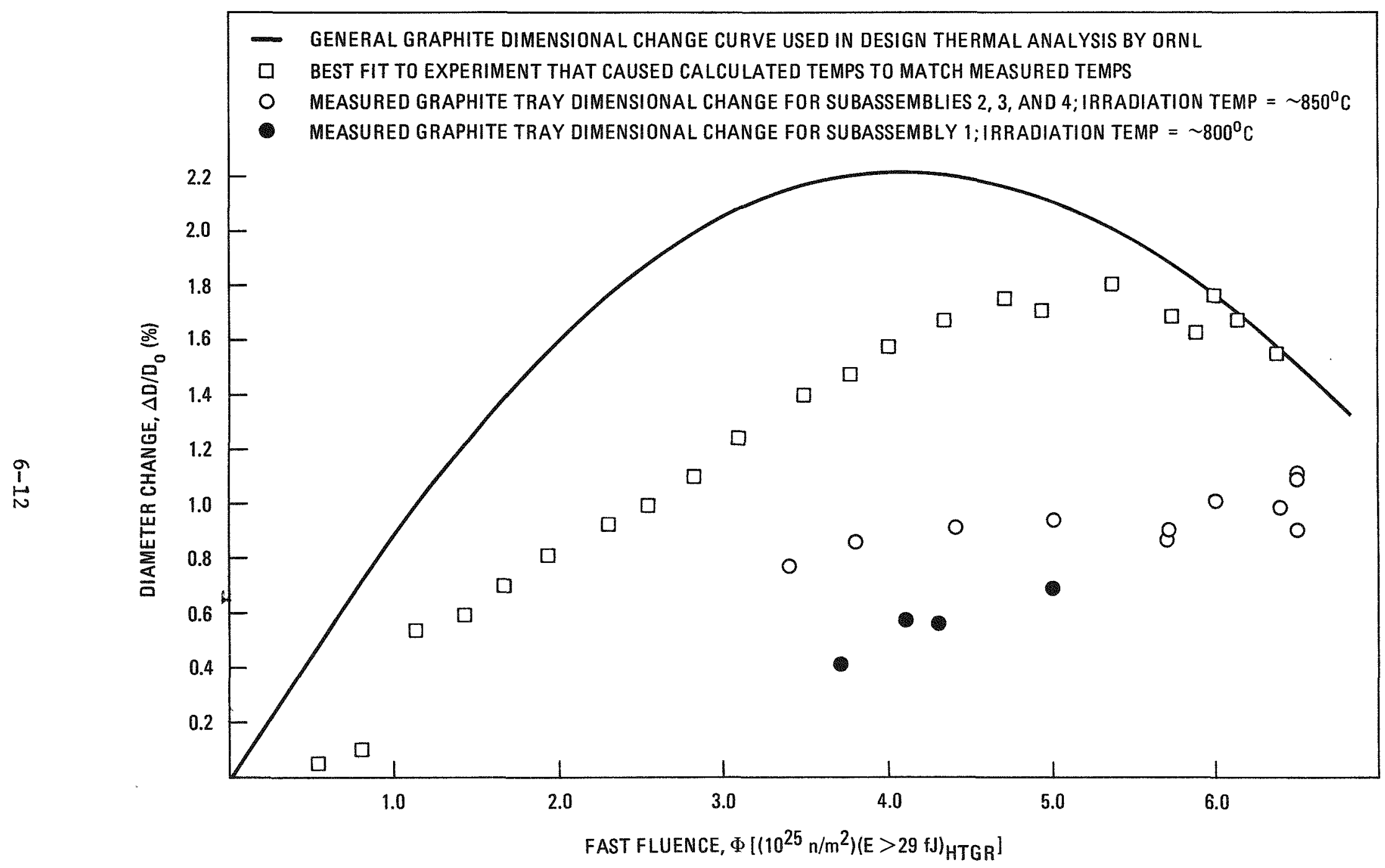

Fig. 6-1. POCO graphite dimensional change versus fast fluence in HRB-15B 


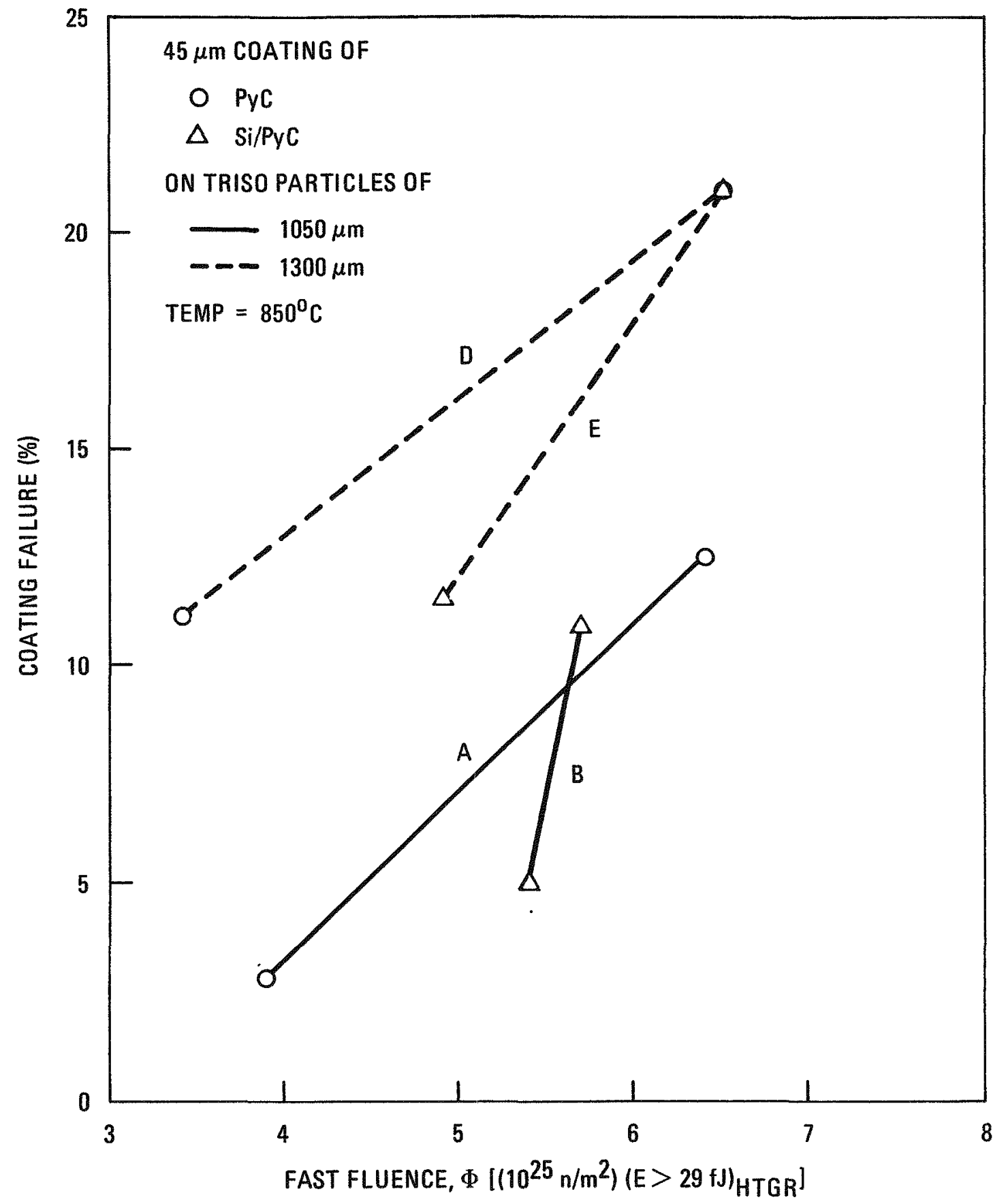

Fig. 6-2. Outer coating fallure versus fluence for two sizes of particles with two different types of coatings 


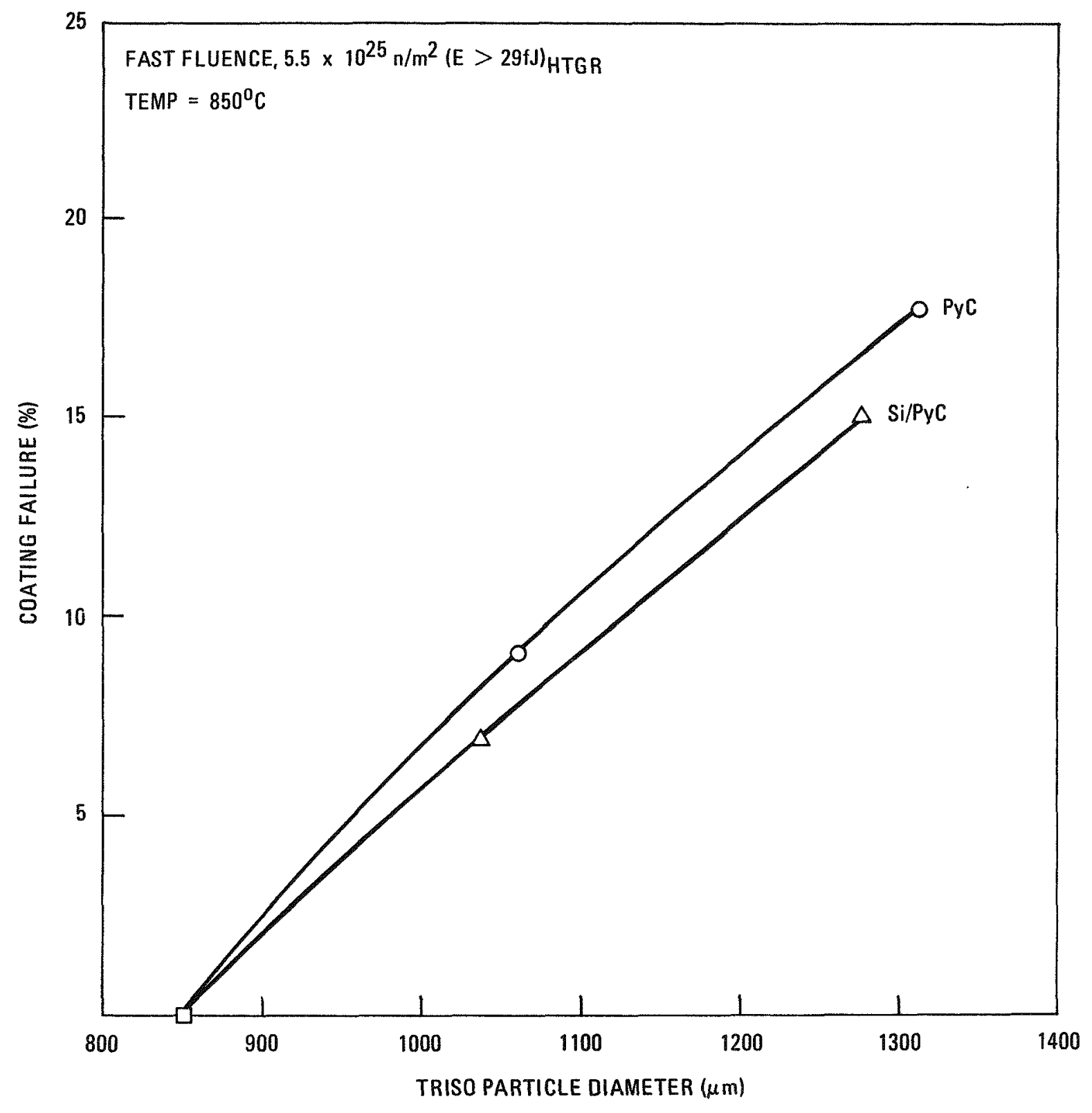

Fig. 6-3. Outer coating failure as a function of particle size 


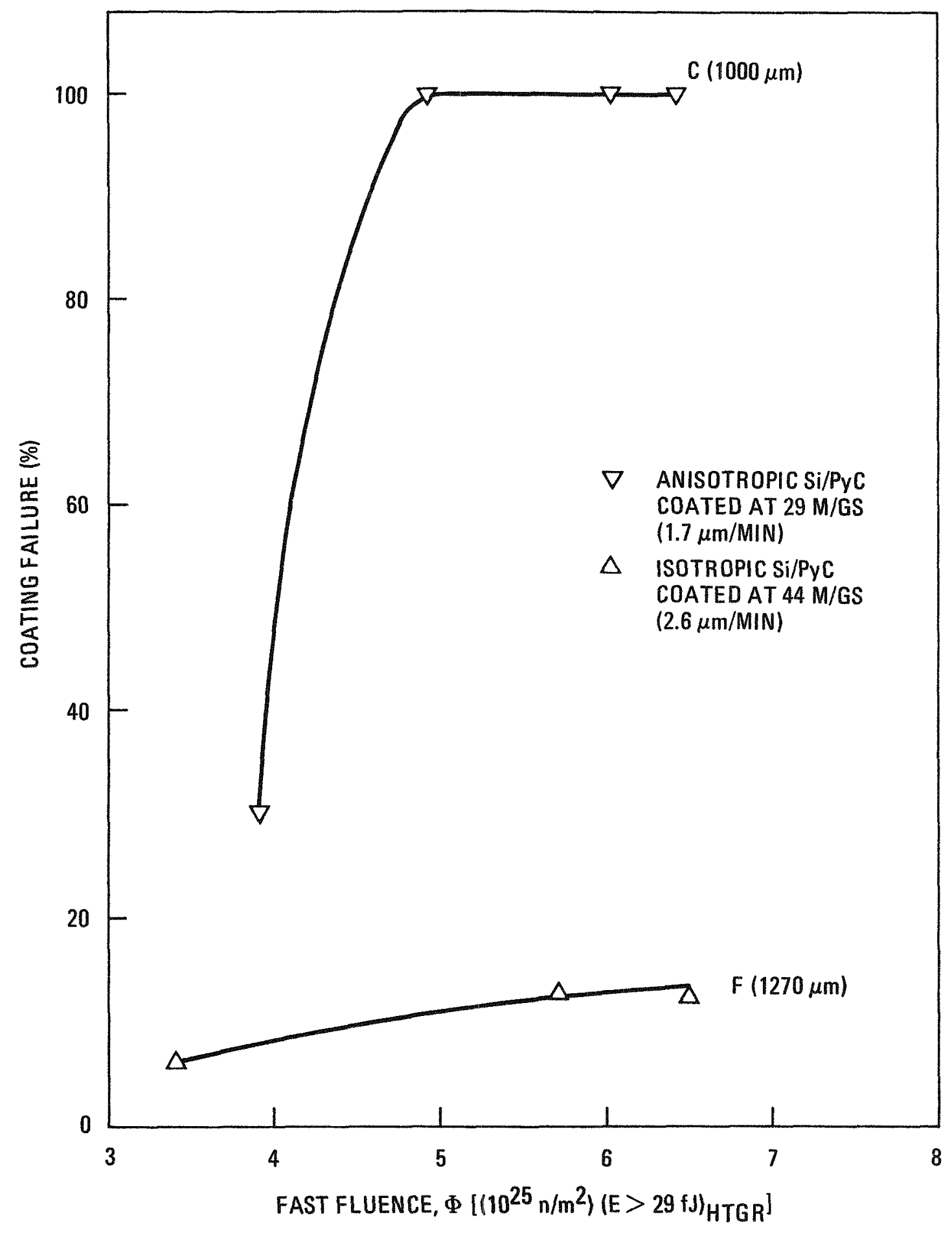

Fig. 6-4. Effect of deposition rate on coating failure 
TABLE 6-1

MEASURED AND CALCULATED PERCENT RELEASE VALUES FOR Cs-137 AND Ag-110m

FROM FISSILE PARTICLES IRRADIATED IN CAPSULE HRB-15B

\begin{tabular}{|c|c|c|c|c|c|}
\hline \multirow[b]{2}{*}{ Test/Analysis } & \multicolumn{2}{|c|}{$\begin{array}{c}\text { TRISO } \\
(\%)\end{array}$} & \multicolumn{2}{|c|}{$\begin{array}{c}\text { Si-BISO } \\
(\%)\end{array}$} & \multirow[b]{2}{*}{ Comments } \\
\hline & Cs -137 & $\mathrm{Ag}-110 \mathrm{~m}$ & $\mathrm{Cs}-137$ & $\mathrm{Ag}-110 \mathrm{~m}$ & \\
\hline $\begin{array}{l}\text { Performance model } \\
\text { predictions }(a)\end{array}$ & 0 & 0 & 0 & (b) & $\begin{array}{l}\text { Difficult to compare zero release } \\
\text { predictions with quantitative } \\
\text { measurements }\end{array}$ \\
\hline $\begin{array}{l}\text { IMGA results with } \\
\mathrm{Zr}-95 \text { as stable isotope } \\
\text { IMGA results with } \\
\text { Ru-106 as stable isotope }\end{array}$ & 0 to 8 & $\begin{array}{l}0 \text { to } 17 \\
22 \text { to } 32\end{array}$ & 0 to 4 & $\begin{array}{l}15 \text { to } 17 \\
23 \text { to } 32\end{array}$ & $\begin{array}{l}\text { These IMGA results were insensitive } \\
\text { to particle type, capsule position, } \\
\text { and burnup. } \mathrm{Ag}-110 \mathrm{~m} \text { is difficult to } \\
\text { measure in irradiated particles } \\
\text { because of high background activity. }\end{array}$ \\
\hline $\begin{array}{l}\text { Gamma-scans of empty } \\
\text { particle trays }\end{array}$ & 0 & 0.15 to 0.6 & 0.04 to 0.05 & 2 to 13 & $\begin{array}{l}\text { Improved precision because of low } \\
\text { background activity. Not all } \\
\text { irradiated trays gamma-scanned. }\end{array}$ \\
\hline Conclusions & No release & $\begin{array}{l}\text { Less than } \\
1 \% \text { release }\end{array}$ & No release & $\sim 10 \%$ release & $\begin{array}{l}\text { Uncertainties in the results stem } \\
\text { from assumptions used in calculating } \\
\text { theoretical and measured } \\
\text { inventories. }\end{array}$ \\
\hline
\end{tabular}

(a) Private communications of diffusive release predictions by B. F. Myers at GA, June 1980 to December 1980.

(b) No prediction made since silver transport data in Si-PyC are not available. 


\section{CONCLUSIONS}

Capsule $\mathrm{HRB}-15 \mathrm{~B}$ irradiated numerous candidate LEU fissile kernel types and particle designs at exposure levels of 3.0 to $6.6 \times 10^{25} \mathrm{n} / \mathrm{m}^{2}$ ( $\mathrm{E}>29$ fJ) HTGR fast fluence, $19 \%$ to $27 \%$ FIMA fissile burnup, $1.7 \%$ to $6.0 \%$ FIMA fertile burnup, and time-averaged maximum particle surface temperatures from $815^{\circ}$ to $915^{\circ} \mathrm{C}$ with the following results (the capsule objective from Section 2.1 to which each conclusion applies is noted where appropriate):

1. No performance disadvantages were identified in any of the LEU fissile candidate particle types (see Section 2.3.1) tested $(1,2)$.

2. No kernel migration, pressure vessel failure, SiC attack, or oPyC failure (except for inerts) were observed $(1,4)$.

3. Evidence gathered after irradiation indicates that all TRISOcoated fissile particles tested remained intact and retained virtually all of their fission products. Findings indicate silver release from these particles no greater than $1 \%(1,2)$.

4. No differences were observed in the performance of three $U_{\mathrm{x}} \mathrm{O}_{\mathrm{y}}$ kernel types with varying $0 / U$ ratios (3).

5. Particle tray autoradiograpy and gamma-scans of the trays and particles showed that silver release occurred from the Si-BISOcoated fissile particles, with the indicated losses ranging from 0 to $30 \%$. Cesium was retained, as predicted in these fissile particles, but measured releases of cesium from $0.1 \%$ to $0.2 \%$ from the fertile Si-BISO particles exceeded performance model predictions (6). 
6. The $\mathrm{UO}_{2}^{*}$ particles (with $\mathrm{ZrC}$ added to buffer the oxygen potential) performed as expected at the exposure levels encountered in this test. Carbon growth features observed within the kernels of the gettered particle types were not seen in the standard, unbuffered $\mathrm{UO}_{2}$ particles (5).

7. OPyC density changes agreed fairly well with published data for standard OPyC coatings. Measured density changes of silicondoped OPyC coatings ranged from $-4 \%$ to $-7 \%$, which were inconsistent with published values for unrestrained silicon-OPyC density changes.

8. Measured POCO graphite dimensional changes in HRB-15B did not agree with general design data currently used in thermal analysis codes at ORNL, primarily because of temperature effects.

9. The failure rate of outer coatings on TRISO particles caused by irradiation-induced shrinkage onto the more stable $\mathrm{SiC}$ substrate increases for a given neutron fluence and irradiation temperature as the particle size increases, consistent with predictions of Weibu11 theory.

10. Seven density-separated TRISO-coated particle samples with thin buffer layers showed no pressure vessel failures, consistent with predictions for irradiation temperatures lower than the normal design limit of $1250^{\circ} \mathrm{C}(4)$. 


\section{REFERENCES}

1. Ketterer, J. W., "Capsule HRB-15B Preirradiation Report," General Atomic unpublished data.*

2. Thomas, W. E., et a1., "HTGR Experiment HRB-15B: Particle Loadings and Irradiation in the High Flux Isotope Reactor," Oak Ridge National Laboratory Report TM-6892, December 1979.

3. Young, C. A., "Pre- and Postirradiation Evaluation of the Fuel Irradiated in Capsule HRB-14," Genera1 Atomic Report GA-A15969, to be published.

4. Stansfield, 0. M., et a1., "Performance of $\mathrm{ThO}_{2}$ in HTGR Fuel Particles," DOE Report GA-A14745, General Atomic Company, March 1978.

5. Weber, G. W., R. L. Beatty, and V. J. Tennery, "Processing and Composition Control of Weak-Acid-Resin-Derived Fuel Microspheres," Nuc1. Tech. 35, No. 2, 217 (1977).

6. Scheffel, W. J., "Postirradiation Examination of Capsule P13T," General Atomic Report GA-A15608, to be published.

7. Sedlak, B. J., "Postirradiation Examination Report of TRISO and BISO Coated $\mathrm{ThO}_{2}$ Particles Irradiated in Capsules $\mathrm{HT}-31$ and HT-33," DOE Report GA-A15544, General Atomic Company, January 1980.

8. "HTGR Base-Technology Program Annual Progress Report for Period Ending December 31, 1978," Oak Ridge National Laboratory Document 5536, pp. 95-99.

9. Harmon, D. P., and C. B. Scott, "Development and Irradiation Performance of LHTGR Fue1," ERDA Report GA-A13173, Genera1 Atomic Company, October 31, 1975 .

\footnotetext{
* Unpublished data are stored in the General Atomic Engineering Division files.
} 
10. Kaae, J. E., et a1., "High-Fluence Irradiation-Induced Dimensional Changes of Co-Deposited Carbon-Silicon Alloys," Carbon 10, 285-292 (1972).

11. Homan, F. J., H. Nabielek, and L. Yang, "Low-Enriched Fuel Particle Performance Review," General Atomic Report GA-A14759, August 1978.

12. Sterling, S. A., "Cesium Release From Various Advanced HTGR Fertile Particle Designs," General Atomic Report GA-A15230, February 1979.

13. Engle, G. B., "Relationship Between Crystal Structure and Properties and Irradiation Behavior of Reactor Graphites," General Atomic Report GA-A12124, June 30, 1972. 


\section{ACKNOWLEDGMENTS}

The authors are grateful to the many people at both GA and ORNL who contributed specialized talents toward this project.

We particularly acknowledge the following ORNL personnel: E. L. Long, Jr. for overall project responsibility and liaison; J. M. Robbins and B. R. Chilcoat for fuel fabrication and capsule assembly, respectively; John Colin and W. E. Thomas for the design thermal analysis; T. N. Tiegs for coordinating the microprobe analysis and for IMGA measurements and analysis; and hot cell personne1.

At GA, we wish to thank L. Yang and J. L. Kaae for fuel sample fabrication; D. S. Brush for Quality Assurance; W. E. Simpson for metallographic examinations; N. Johnson for particle tray autoradiography; T. B. Crockett for gamma-scan, fission gas release measurements, and burnup analysis; B. E. Myers and C. L. Smith of the Fuel Chemistry Branch for technical support; all members of the Fuel Materials Branch, both lab personnel and staff, for technical support; and M. R. Veerman, M. D. Reade1, and J. E. Baker for typing the draft of this report. 
APPENDIX A

FUEL SAMPLE EXPOSURE LEVELS IN HRB-15B

$A-1$ 
$$
\text { . }
$$ 


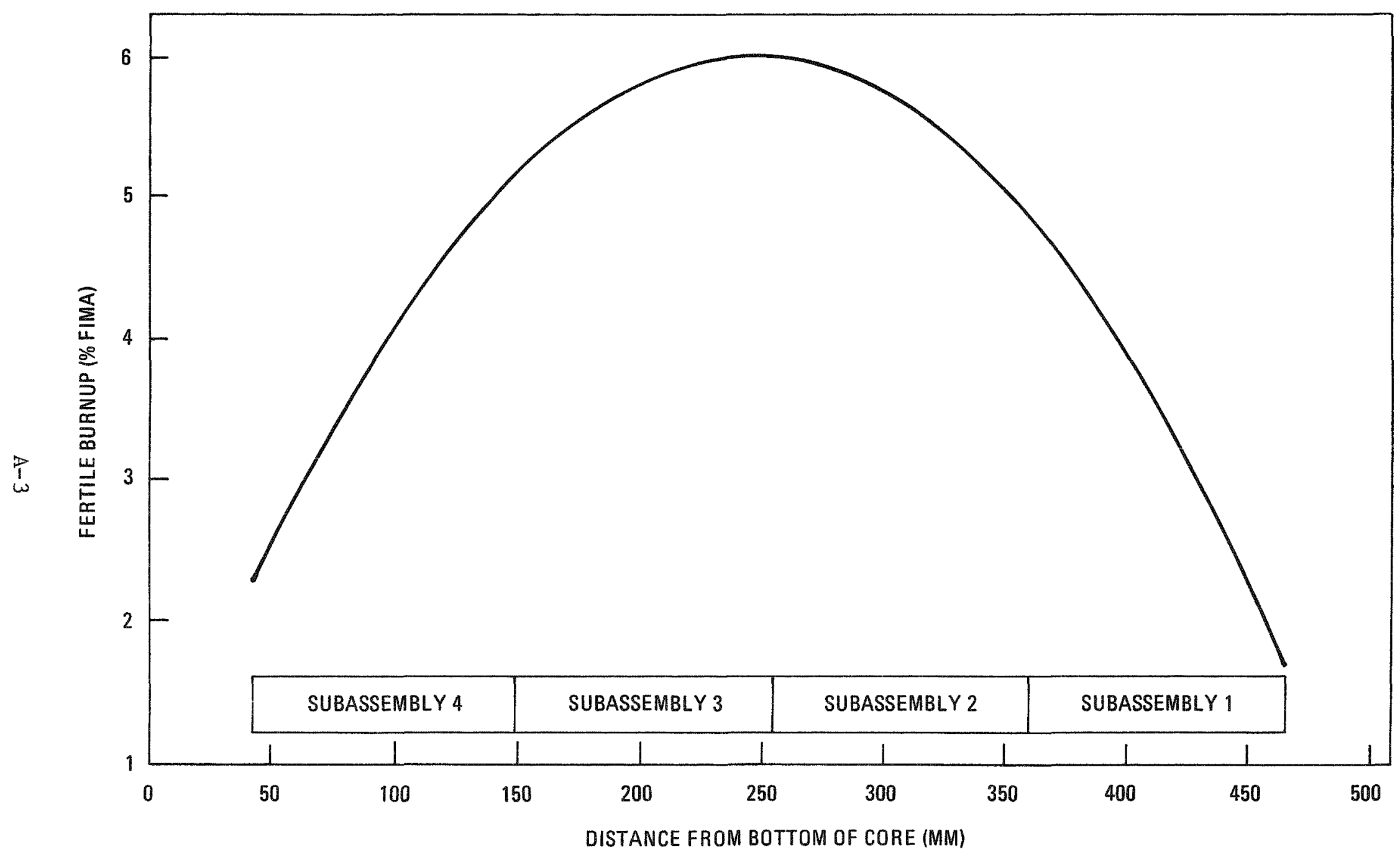

Fig. A-1. Fertile burnup versus position in HRB-15B 


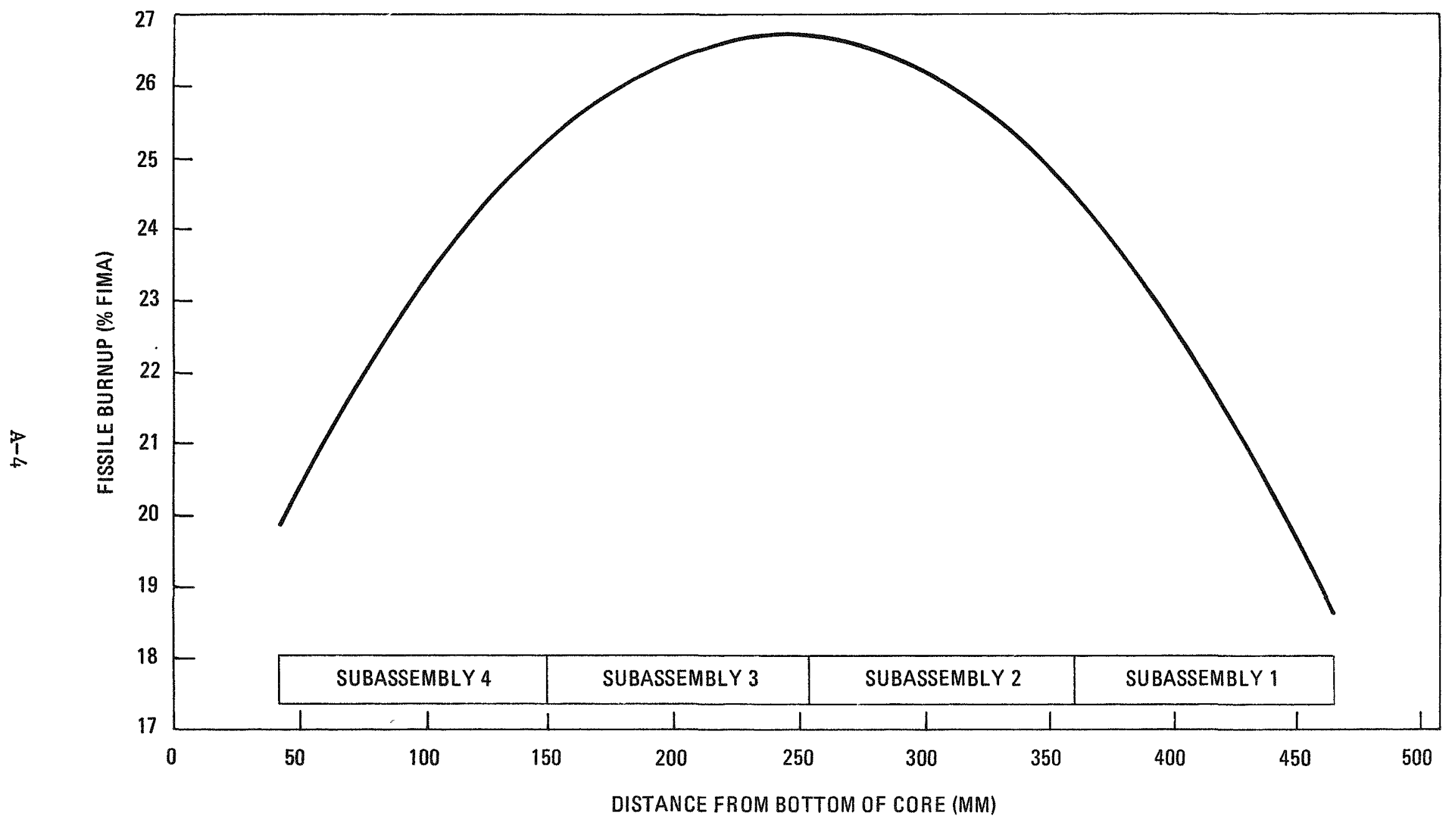

Fig. A-2. Fissile burnup versus position in $\mathrm{HRB}-15 \mathrm{~B}$ 


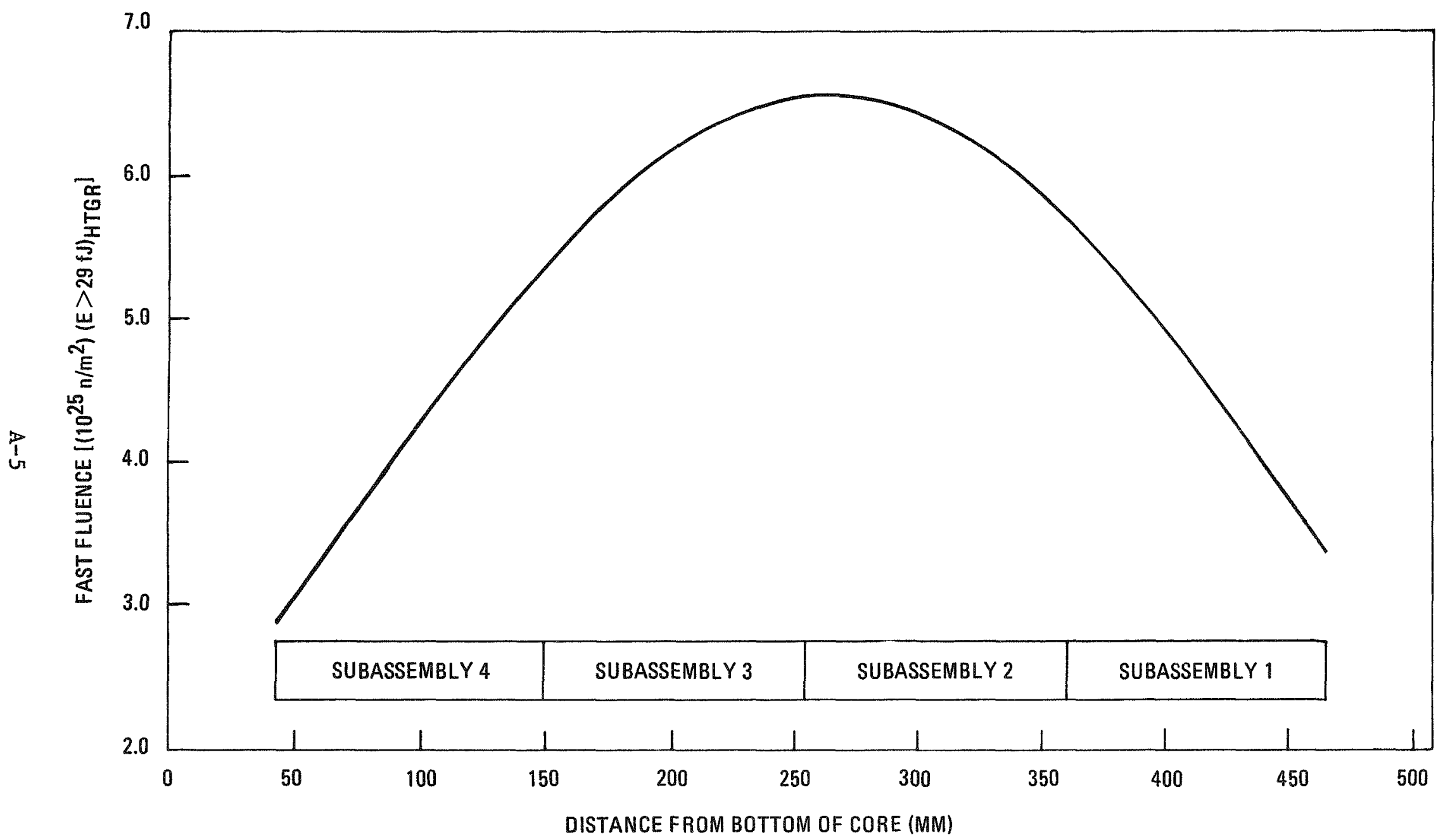

Fig. A-3. Fast fluence versus position in HRB-15B 
TABLE A-1

HRB-15B PARTICLE EXPOSURE LEVELS FOR SUBASSEMBLY 1

\begin{tabular}{|c|c|c|c|c|c|c|c|c|c|}
\hline \multirow{2}{*}{$\begin{array}{l}\text { Tray } \\
\text { No. }\end{array}$} & \multicolumn{2}{|c|}{ Experimenter } & \multirow{2}{*}{$\begin{array}{c}\text { Kerne } 1 \\
\text { Type }\end{array}$} & \multirow{2}{*}{$\begin{array}{l}\text { Coating } \\
\text { Type }\end{array}$} & \multirow{2}{*}{$\begin{array}{l}\text { Sample } \\
\text { No. }\end{array}$} & \multirow{2}{*}{$\begin{array}{l}\text { Maximum } \\
\text { Particle } \\
\text { Surface } \\
\text { Temp } \\
\left({ }^{\circ} \mathrm{C}\right)\end{array}$} & \multirow{2}{*}{$\begin{array}{c}\text { Fast Fluence, } \\
\$\left(\left(10^{25} \mathrm{n} / \mathrm{n}^{2}\right)\right. \\
(\mathrm{E}>29 \mathrm{fJ})_{\mathrm{HTGR} J}\end{array}$} & \multicolumn{2}{|c|}{$\begin{array}{l}\text { Kernel Burnup } \\
\text { (\% FIMA) }\end{array}$} \\
\hline & $\mathrm{GA}$ & ORNL & & & & & & Fissile & Fertile \\
\hline 1 & & $\mathrm{x}$ & $\mathrm{ThO}_{2}$ & TRISO & $\mathrm{A}-824-\mathrm{HT}-1$ & 815 & 3.4 & -- & 1.7 \\
\hline 2 & $\mathrm{x}$ & & $(\mathrm{Th}, \mathrm{U}) \mathrm{O}_{2}$ & SI-BISO & $6445-01-0110-1$ & 840 & 3.4 & 10.3 & -- \\
\hline 3 & & $x$ & $\mathrm{ThO}_{2}$ & TRISO & A-825-HT-1 & 815 & 3.5 & -- & 1.9 \\
\hline 4 & $x$ & & $\mathrm{UO}_{2}$ & Si-BISO & $6447-00-0110-1$ & 860 & 3.6 & 19.1 & - \\
\hline 5 & $\mathrm{x}$ & & $\mathrm{ThO}_{2}$ & Si-BISo & $6542-42-0210-1$ & 815 & 3.6 & -- & 2.1 \\
\hline 6 & $\mathrm{x}$ & & $\mathrm{vC}_{0.490_{1} .12}$ & Si-BISO & $6448-01-0110-1$ & 860 & 3.7 & 19.4 & - \\
\hline 7 & & $\mathrm{x}$ & $\mathrm{ThO}_{2}$ & TRISO & $A-826-H T-1$ & 815 & 3.7 & -- & 2.3 \\
\hline 8 & $x$ & & $(\mathrm{Th}, U) \mathrm{O}_{2}$ & TRISO & $6155-05-0111-1$ & 840 & 3.8 & 11.1 & - \\
\hline 9 & & $x$ & $\mathrm{ThO}_{2}$ & TRISO & $A-827-H T-1$ & 815 & 3.8 & -- & 2.4 \\
\hline 10 & $\mathrm{x}$ & & $(\mathrm{Th}, \mathrm{U}) \mathrm{O}_{2}$ & TRISO & $6155-05-0111-2$ & 840 & 3.9 & 11.3 & -- \\
\hline 11 & & $\mathrm{x}$ & $\mathrm{ThO}_{2}$ & TRISO & $\mathrm{A}-828-\mathrm{HT}-1$ & 815 & 3.9 & - & 2.6 \\
\hline 12 & & & $\mathrm{vC}_{0.490_{1.12}}$ & TRISO & $6157-08-0311-1$ & 860 & 4.0 & 20.3 & -- \\
\hline 13 & & $\mathrm{x}$ & $\mathrm{ThO}_{2}$ & TRISO & A-833-HT-1 & 815 & 4.0 & - & 2.8 \\
\hline 14 & $x$ & & $U C_{0.49 O_{1} .12}$ & TRISO & $6157-08-0311-2$ & 860 & 4.1 & 20.6 & -- \\
\hline 15 & $\mathrm{x}$ & & $\mathrm{ThO}_{2}$ & TRISO & $6252-15-0140-1$ & 815 & 4.2 & -- & 2.9 \\
\hline 16 & $x$ & & $\mathrm{UO}_{2}$ & TRISO & $6152-01-0120-1$ & 860 & 4.2 & 20.9 & -- \\
\hline 17 & & $\mathrm{x}$ & $\mathrm{ThO}_{2}$ & TRISO & $\mathrm{A}-834-\mathrm{HT}-1$ & 815 & 4.3 & - & 3.1 \\
\hline 18 & $\mathrm{x}$ & & $\mathrm{uC}_{0.69} 0^{\circ} 0.51$ & TRISO & $6157-08-0210-1$ & 860 & 4.3 & 21.2 & - \\
\hline 19 & & $\mathrm{x}$ & $\mathrm{ThO}_{2}$ & TRISO & A-835-HT-1 & 815 & 4.4 & -- & 3.2 \\
\hline 20 & $\mathrm{x}$ & & $\mathrm{uc}_{2}$ & Si-BISO & $6449-00-0110-1$ & 860 & 4.4 & 21.5 & -- \\
\hline 21 & $\mathrm{x}$ & & $\mathrm{ThO}_{2}$ & Si-BISO & $6542-42-0210-2$ & 815 & 4.5 & - & 3.4 \\
\hline 22 & $\mathrm{x}$ & & $\mathrm{uC}_{0.20^{\circ}} \mathrm{O}_{1.64}$ & TRISO & $6157-09-0120-1$ & 860 & 4.5 & 21.7 & - \\
\hline 23 & $\mathrm{x}$ & & $\mathrm{ThO}_{2}$ & TRISO & $6252-15-0140-2$ & 815 & 4.6 & -- & 3.5 \\
\hline Spacer & & & & & & & & & \\
\hline 24 & $\mathrm{x}$ & & $\mathrm{vo}_{2}^{*(\mathrm{a})}$ & Si-BISO & $6447-01-0110-1$ & 860 & 4.6 & 22.0 & -- \\
\hline 25 & & $\mathrm{x}$ & $\mathrm{ThO}_{2}$ & TRISO & $A-836-H T-1$ & 815 & 4.7 & -- & 3.6 \\
\hline 26 & $\mathrm{x}$ & & $\mathrm{vC}_{0.200_{1} .64}$ & TRISO & $6157-09-0111-1$ & 860 & 4.7 & 22.3 & -- \\
\hline 27 & & $\mathrm{x}$ & $\mathrm{ThO}_{2}$ & TRISO & A-837-нT-1 & 815 & 4.8 & -- & 3.8 \\
\hline 28 & $\mathrm{x}$ & & $\mathrm{vo}_{2}^{*(b)}$ & Si-BISO & $6447-02-0110-1$ & 860 & 4.8 & 22.5 & - \\
\hline 29 & & $x$ & $\mathrm{ThO}_{2}$ & TRISO & $A-824-H T-2$ & 815 & 4.9 & - & 3.9 \\
\hline 30 & $\mathrm{x}$ & & $\mathrm{vc}_{0.6900 .51}$ & TRISO & $6157-08-0210-2$ & 860 & 5.0 & 22.7 & - \\
\hline 31 & $\mathrm{x}$ & & $\mathrm{ThO}_{2}$ & BISO & $6542-27-0190-1$ & 815 & 5.0 & -- & 4.0 \\
\hline 32 & $\mathrm{x}$ & & $\mathrm{UO}_{2}$ & TRISO & $6152-01-0120-2$ & 860 & 5.1 & 23.0 & -- \\
\hline 33 & $x$ & & $\mathrm{ThO}_{2}$ & Si-BISO & $6542-42-0210-3$ & 815 & 5.1 & -- & 4.1 \\
\hline 34 & $\mathrm{x}$ & & $\mathrm{uc}_{2}$ & TRISO & $6151-21-0120-1$ & 860 & 5.1 & 23.2 & - \\
\hline 35 & & $\mathrm{x}$ & $\mathrm{ThO}_{2}$ & TRISO & $A-825-H T-2$ & 815 & 5.2 & -- & 4.3 \\
\hline 36 & $\mathrm{x}$ & & $\mathrm{UO}_{2}$ & TRISO & $6152-01-0111-1$ & 860 & 5.2 & 23.4 & -- \\
\hline 37 & & $\mathrm{x}$ & $\mathrm{ThO}_{2}$ & TRISO & $A-826-H T-2$ & 815 & 5.3 & - & 4.4 \\
\hline 38 & $\mathrm{x}$ & & $\mathrm{uc}_{2}$ & TRISO & $6151-21-0111-1$ & 860 & 5.3 & 23.6 & - \\
\hline 39 & & $\mathrm{x}$ & $\mathrm{ThO}_{2}$ & TRISO & $A-827-H T-2$ & 815 & 5.4 & -- & 4.5 \\
\hline 40 & $\mathrm{x}$ & & $v 0 z^{*(b)}$ & TRISO & $6152-03-0111-1$ & 860 & 5.4 & 23.8 & -- \\
\hline 41 & & $\mathrm{x}$ & $\mathrm{ThO}_{2}$ & TRISO & $A-828-4 t-2$ & 815 & 5.5 & - & 4.6 \\
\hline 42 & $\mathrm{x}$ & & $\mathrm{UO}_{2}^{*(\mathrm{~b})}$ & TRISO & $6152-03-0111-2$ & 860 & 5.5 & 24.0 & -- \\
\hline 43 & $\mathrm{x}$ & & $\mathrm{ThO}_{2}$ & TRISO & $6252-15-0131-1$ & 815 & 5.5 & - & 4.7 \\
\hline 44 & $\mathrm{x}$ & & $u c_{0.2001 .64}$ & TRISO & $6157-09-0120-3$ & 860 & 5.6 & 24.2 & - \\
\hline 45 & & $\mathrm{x}$ & $\mathrm{ThO}_{2}$ & TRISO & $A-833-H T-2$ & 815 & 5.6 & - & 4.8 \\
\hline 46 & $\mathrm{x}$ & & $\mathrm{uc}_{2}$ & TRISO & $6151-21-0111-2$ & 860 & 5.7 & 24.4 & -- \\
\hline
\end{tabular}

(a) This particle type had a $\mathrm{ZrC}-$ doped buffer layer.

(b) This particle type had a 5- Im-thick 2 rC layer applied to the kernel. 
TABLE A-2

HRB-15B PARTICLE EXPOSURE LEVELS FOR SUBASSEMBLY 2

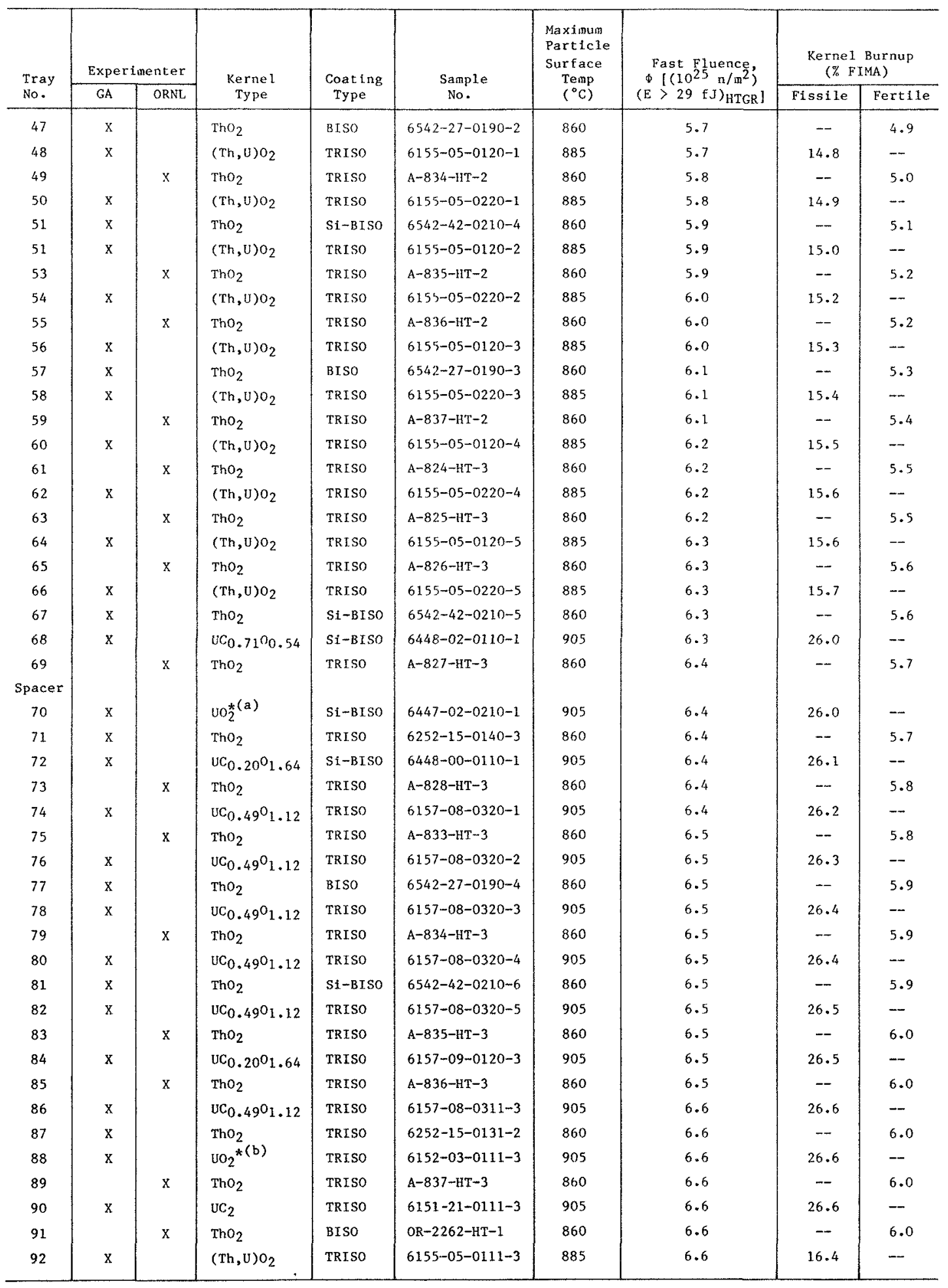

(a) This particle type had a 10-4m-thick Zrc layer applied to the kernel.

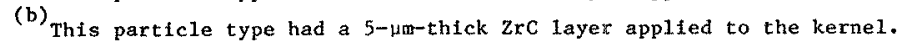


TABLE A-3

HRB-15B PARTICLE EXPOSURE LEVELS FOR SUBASSEMBLY 3

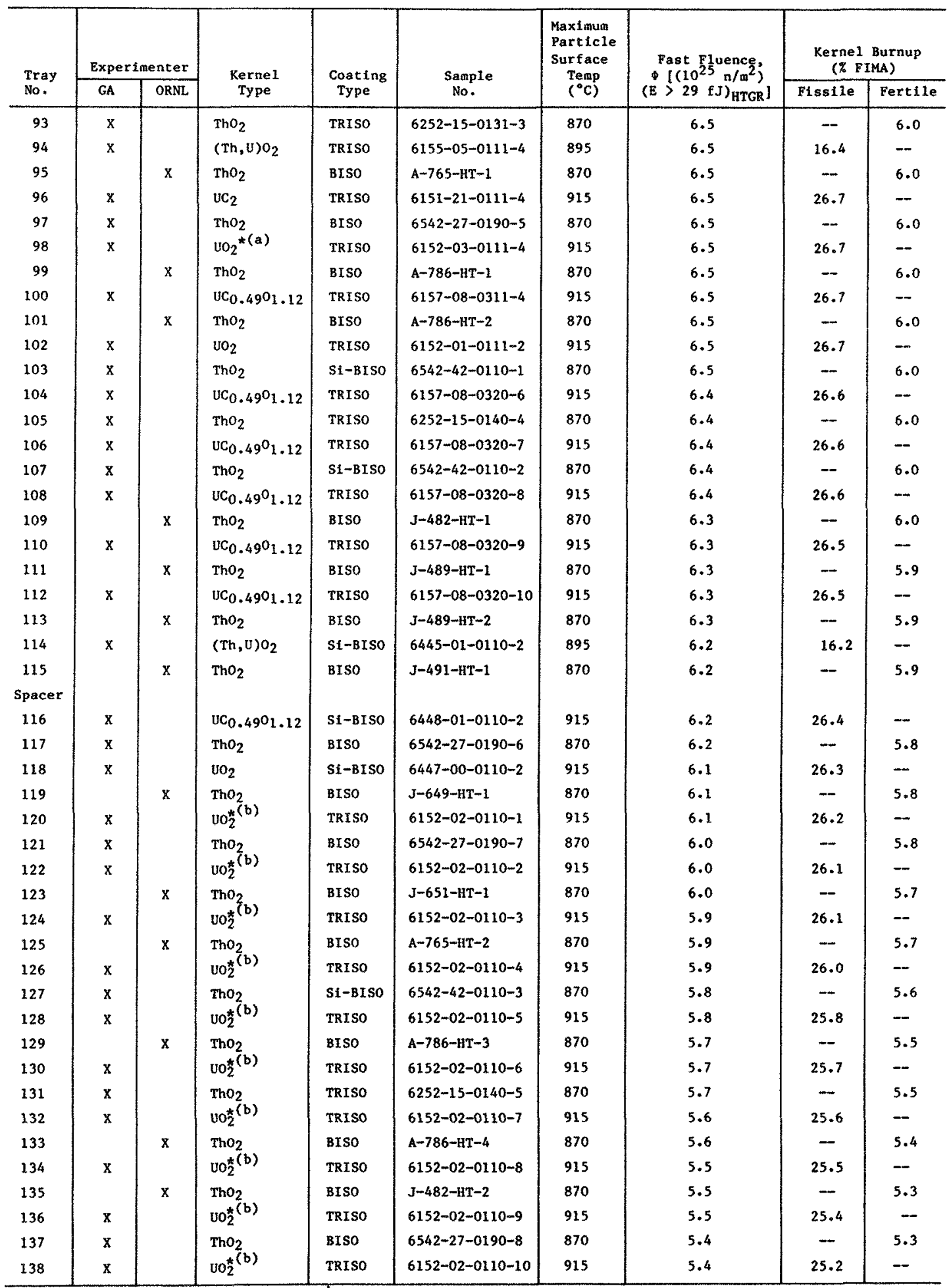

(a) This particle type had a 5-um-thick ZrC layer applled to the kernel.

(b) This particle type had a $\mathrm{ZrC}$-doped buffer layer. 
TABLE A-4

HRB-15B PARTICLE EXPOSURE LEVELS FOR SUBASSEMBLY 4

\begin{tabular}{|c|c|c|c|c|c|c|c|c|c|}
\hline \multirow{2}{*}{$\begin{array}{l}\text { Tray } \\
\text { No. }\end{array}$} & \multicolumn{2}{|c|}{ Experimenter } & \multirow{2}{*}{$\begin{array}{l}\text { Kernel } \\
\text { Type }\end{array}$} & \multirow{2}{*}{$\begin{array}{l}\text { Coating } \\
\text { Type }\end{array}$} & \multirow{2}{*}{$\begin{array}{l}\text { Sample } \\
\text { No. }\end{array}$} & \multirow{2}{*}{$\begin{array}{l}\text { Maximum } \\
\text { Particle } \\
\text { Surface } \\
\text { Temp } \\
\left({ }^{\circ} \mathrm{C}\right)\end{array}$} & \multirow{2}{*}{$\begin{array}{c}\text { Fast F1uence, } \\
\Phi\left[\left(10^{25} \mathrm{n} / \mathrm{m}^{2}\right)\right. \\
\left.(E>29 \mathrm{fJ})_{\mathrm{HTGR}}\right]\end{array}$} & \multicolumn{2}{|c|}{$\begin{array}{l}\text { Kernel Burnup } \\
(\% \text { FIMA) }\end{array}$} \\
\hline & $G A$ & ORNL & & & & & & Fissile & Fertile \\
\hline 139 & & \multirow[t]{4}{*}{$x$} & ThO $_{2}$ & BISO & $\mathrm{J}-489-\mathrm{HT}-3$ & 870 & 5.3 & - & 5.2 \\
\hline 140 & $\mathrm{x}$ & & $(\mathrm{Th}, \mathrm{U}) \mathrm{O}_{2}$ & TRISO & $6155-05-0111-5$ & 895 & 5.3 & 15.1 & -- \\
\hline 141 & $\mathrm{x}$ & & $\mathrm{ThO}_{2}$ & SI-BISO & $6542-42-0110-4$ & 870 & 5.2 & - & 5.1 \\
\hline 142 & $\mathrm{x}$ & & $\mathrm{UC}_{0.490_{1.12}}$ & TRISO & $6157-08-0311-5$ & 915 & 5.2 & 24.9 & 5.0 \\
\hline 143 & & \multirow[t]{4}{*}{$\mathrm{x}$} & $\mathrm{ThO}_{2}$ & BISO & $J-489-H T-4$ & 870 & 5.2 & -- & 5.0 \\
\hline 144 & $x$ & & $(\mathrm{Th}, \mathrm{U}) \mathrm{O}_{2}$ & TRISO & $6155-05-0111-6$ & 895 & 5.1 & 14.9 & - \\
\hline 145 & $x$ & & $\mathrm{ThO}_{2}$ & TRISO & $6252-15-0131-4$ & 870 & 5.0 & - & 4.9 \\
\hline 146 & $\mathrm{x}$ & & $\mathrm{UC}_{0.490_{1.12}}$ & TRISO & $6157-08-0311-6$ & 915 & 5.0 & 24.6 & $\rightarrow$ \\
\hline 147 & & \multirow[t]{2}{*}{$\mathrm{x}$} & $\mathrm{ThO}_{2}$ & BISO & $J-491-H T-2$ & 870 & 4.9 & - & 4.8 \\
\hline 148 & $x$ & & $\mathrm{vO}_{2}$ & TRISO & $6152-01-0120-3$ & 915 & 4.9 & 24.2 & -- \\
\hline 149 & & \multirow[t]{2}{*}{$\mathrm{x}$} & $\mathrm{ThO}_{2}$ & BISO & $\mathrm{J}-649-\mathrm{HT}-2$ & 870 & 4.8 & - & 4.7 \\
\hline 150 & $\mathrm{x}$ & & $\mathrm{UC}_{0.69^{\circ}} 0.51$ & TRISO & $6157-08-0210-3$ & 915 & 4.8 & 24.2 & -- \\
\hline 151 & & \multirow[t]{4}{*}{$x$} & $\mathrm{ThO}_{2}$ & BISO & $\mathrm{J}-651-\mathrm{HT}-2$ & 870 & 4.7 & - & 4.6 \\
\hline 152 & $x$ & & $u c_{0.20^{\circ}} 01.64$ & TRISO & $6157-09-0120-4$ & 915 & 4.7 & 24.0 & - \\
\hline 153 & $\mathrm{x}$ & & $\mathrm{ThO}_{2}$ & BISO & $6542-27-0190-9$ & 870 & 4.7 & -- & 4.5 \\
\hline 154 & $\mathrm{x}$ & & $\mathrm{vo}_{2}^{*}(\mathrm{a})$ & Si-BISO & $6447-02-0210-2$ & 915 & 4.6 & 23.8 & - \\
\hline 155 & & \multirow[t]{2}{*}{$\mathrm{x}$} & $\mathrm{ThO}_{2}$ & BISO & A-765-HT-3 & 870 & 4.5 & -- & 4.4 \\
\hline 156 & $\mathrm{x}$ & & $\mathrm{vO}_{2}{ }^{*(b)}$ & SI-BISO & $6447-01-0110-2$ & 915 & 4.5 & 23.6 & - \\
\hline 157 & & \multirow[t]{2}{*}{$\mathrm{x}$} & $\mathrm{ThO}_{2}$ & BISO & $A-786-\mathrm{HT}-5$ & 870 & 4.4 & - & $4 \cdot 3$ \\
\hline 158 & $\mathrm{x}$ & & $\mathrm{UC}_{2}$ & $\mathrm{SI}-\mathrm{BISO}$ & $6449-00-0110-2$ & 915 & 4.4 & 23.4 & - \\
\hline 159 & & \multirow[t]{7}{*}{$\mathrm{x}$} & $\mathrm{ThO}_{2}$ & BISO & $A-786-H T-6$ & 870 & 4.3 & -- & 4.2 \\
\hline 160 & $\mathbf{x}$ & & $u c_{0.20^{0}} 1.64$ & TRISO & $6157-09-0111-2$ & 915 & 4.3 & 23.2 & - \\
\hline 161 & $x$ & & $\mathrm{ThO}_{2}$ & Si-BISO & $6542-42-0110-5$ & 870 & 4.2 & -- & 4.1 \\
\hline Spacer & & & & & & & & & \\
\hline 162 & $\mathrm{x}$ & & $100_{2}^{*(a)}$ & TRISO & $6152-03-0210-1$ & 915 & 4.2 & 23.0 & - \\
\hline 163 & $\mathrm{x}$ & & $\mathrm{ThO}_{2}$ & TRISO & $6252-15-0140-6$ & 870 & 4.1 & -- & 3.9 \\
\hline 164 & $\mathrm{x}$ & & $\mathrm{UO}_{2}^{\star(a)}$ & TRISO & $6152-03-0210-2$ & 915 & 4.0 & 22.8 & $\cdots$ \\
\hline 165 & & \multirow[t]{4}{*}{$x$} & $\mathrm{ThO}_{2}$ & BISO & $J-482-H T-3$ & 870 & 4.0 & - & 3.8 \\
\hline 166 & $\mathrm{x}$ & & $\mathrm{UC}_{2}$ & TRISO & $6151-21-0120-2$ & 915 & 3.9 & 22.5 & - \\
\hline 167 & $\mathrm{x}$ & & $\mathrm{ThO}_{2}$ & BISO & $6542-27-0190-10$ & 870 & 3.9 & -- & 3.7 \\
\hline 168 & $\mathrm{x}$ & & $\mathrm{UC}_{0.02} \mathrm{O}_{1.64}$ & TRISO & $6157-09-0120-5$ & 915 & 3.8 & 22.3 & - \\
\hline 169 & & \multirow[t]{2}{*}{$x$} & $\mathrm{ThO}_{2}$ & BISO & $J-489-H T-5$ & 870 & 3.8 & -- & 3.5 \\
\hline 170 & $\mathrm{x}$ & & $\mathrm{UO}_{2}^{*}(\mathrm{c})$ & T'RISO & $6152-03-0111-5$ & 915 & 3.7 & 22.0 & -- \\
\hline 171 & & \multirow[t]{2}{*}{$\mathrm{x}$} & $\mathrm{ThO}_{2}$ & BISO & $\mathrm{J}-489-\mathrm{HT}-6$ & 870 & 3.7 & -- & 3.4 \\
\hline 172 & $\mathrm{x}$ & & $\mathrm{UC}_{2}$ & TRISO & $6151-21-0111-5$ & 915 & 3.6 & 21.8 & - \\
\hline 173 & & \multirow[t]{4}{*}{$\mathrm{x}$} & $\mathrm{ThO}_{2}$ & BISO & $J-491-H T-3$ & 870 & 3.6 & -- & 3.3 \\
\hline 174 & $\mathrm{x}$ & & $\mathrm{uO}_{2}$ & TRISO & $6152-01-0111-3$ & 915 & 3.5 & 21.5 & - \\
\hline 175 & $x$ & & $\mathrm{ThO}_{2}$ & SI-BISO & $6542-42-0110-6$ & 870 & 3.5 & -- & 3.1 \\
\hline 176 & $\mathrm{x}$ & & $\mathrm{UO}_{2}^{*(c)}$ & TRISO & $6152-03-0111-6$ & 915 & 3.4 & 21.2 & - \\
\hline 177 & & $\mathrm{x}$ & $\mathrm{ThO}_{2}$ & BISO & $J-649 m \mathrm{HT}-3$ & 870 & 3.3 & - & 3.0 \\
\hline 178 & $\mathrm{x}$ & & $\mathrm{UC}_{2}$ & TRISO & $6151-21-0111-6$ & 915 & 3.3 & 20.9 & - \\
\hline 179 & & $\mathrm{x}$ & $\mathrm{ThO}_{2}$ & BISO & $J=651-H T-3$ & 870 & 3.2 & -- & 2.8 \\
\hline 180 & $\mathrm{x}$ & & $v C_{0.7100 .54}$ & Si-BISO & $6448-02-0110-2$ & 915 & 3.2 & 20.6 & - \\
\hline 181 & $\mathrm{x}$ & & $\mathrm{ThO}_{2}$ & TRISO & $6252-15-0131-5$ & 870 & 3.1 & -- & 2.7 \\
\hline 182 & $x$ & & $\mathrm{vo}_{2}^{*(c)}$ & Si-BISO & $6447-02-0110-2$ & 915 & 3.1 & 20.3 & - \\
\hline 183 & & $\mathrm{x}$ & $\mathrm{ThO}_{2}$ & BISO & $\mathrm{OR}-2622-\mathrm{HT}-2$ & 870 & 3.0 & -- & 2.5 \\
\hline 184 & $\mathrm{x}$ & & $\mathrm{UC}_{0.20} 0_{1.64}$ & Si-BISO & $6448-00-0110-2$ & 915 & 3.0 & 20.0 & - \\
\hline
\end{tabular}

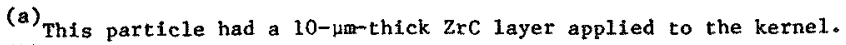

(b) This particle type had a zrC-doped buffer layer.

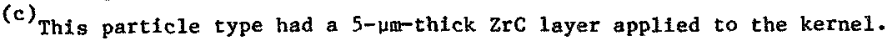


To find the $1 \sigma$ uncertainty in the calculated time-average maximum particle surface temperatures reported in Tables A-1 through A-4, the propagation of errors approach was employed. Mean values and estimated standard derivations were first tabulated for each of the variables in Eq. 4-1. Table B-1 gives these. The equation was then partially derived for each of the independent variables and evaluated using the mean values of the variables. Table B-2 gives these results. The following formula was then used to calculate the uncertainty:

$$
\sigma_{\Delta T_{\max }}=\sqrt{\left(\frac{\partial f}{\partial P}\right)^{2} \sigma_{P}^{2}+\left(\frac{\partial f}{\partial \bar{T}}\right)^{2} \sigma_{\bar{T}}^{2}+\left(\frac{\partial f}{\partial G_{1}}\right)^{2} \sigma_{G_{1}}{ }^{2}+\left(\frac{\partial f}{\partial G_{2}}\right)^{2} \sigma_{G_{2}}^{2}}
$$

The calculated $\sigma_{\Delta \mathrm{T}_{\max }}$ by this method $\simeq 10^{\circ} \mathrm{C}$. To this uncertainty the uncertainty in the time-average graphite tray temperatures is added, which is estimated to be $15^{\circ} \mathrm{C}$. Therefore,

$$
\begin{aligned}
2 \sigma_{\Delta \mathrm{T}_{\max }} & =20^{\circ} \mathrm{C} . \\
\frac{2 \sigma_{\Delta \text { Tray Temp }}}{}=30^{\circ} \mathrm{C} & . \\
2 \sigma_{\text {overa } 11} & =50^{\circ} \mathrm{C} .
\end{aligned}
$$

This is the $95 \%$ confidence estimate of the overall uncertainty in the calculated time-average maximum particle surface temperatures. 
TABLE B-1

MEAN VALUES AND ESTIMATED STANDARD DEVIATIONS . FOR EACH VARIABLE IN EQ • 4-1

\begin{tabular}{c|c|c}
\hline $\begin{array}{c}\text { Variable in } \\
\text { Eq. 4-1 }\end{array}$ & $\begin{array}{c}\text { Mean Time- } \\
\text { Averaged Value }\end{array}$ & $\begin{array}{c}\text { Estimated Standard } \\
\text { Deviation }\end{array}$ \\
\hline $\mathrm{P}$ & $0.4 \mathrm{~W}(\mathrm{a})$ & $2 \sigma= \pm 10 \%, \sigma \mathrm{O}=0.02$ \\
$\overline{\mathrm{T}}$ & $840^{\circ} \mathrm{C}$ & $2 \sigma= \pm 7 \%, \overline{\mathrm{T}}=30$ \\
$\mathrm{G}_{1}$ & 2840 & $2 \sigma= \pm 15 \%, \sigma_{\mathrm{G}}=213$ \\
$\mathrm{G}_{2}$ & 13.3 & $2 \sigma= \pm 15 \%, \sigma_{\mathrm{G}}=0.998$ \\
\hline
\end{tabular}

(a) Fissile, rather than fertile, particle power was used, since the fissile particle is the greater of the two with the larger uncertainly. 
TABLE $B-2$

PARTIAL DERIVATIVES OF EQ • 4-1 AND MEAN VALUE EVALUATIONS FOR USE IN EQ - B-1

\begin{tabular}{c|c}
\hline $\begin{array}{c}\text { Partial Derivatives } \\
\text { of Eq. 4-1 }\end{array}$ & $\begin{array}{c}\text { Evaluation of Partials } \\
\text { Using Mean Values From } \\
\text { Table } B-1\end{array}$ \\
\hline$\frac{\partial f}{\partial_{P}}=\left(G_{1}-\bar{T}\right) / G_{2}$ & 150 \\
$\frac{\partial f}{\partial T}=-P / G_{2}$ & -0.03 \\
$\frac{\partial f}{\partial G_{1}}=P / G_{2}$ & -0.03 \\
$\frac{\partial f}{\partial G_{2}}=-\frac{1}{G_{2}{ }^{2}\left[P\left(G_{1}-\bar{T}\right)\right]}$ & -4.52 \\
\hline
\end{tabular}




\author{
APPENDIX $\mathrm{C}$ \\ GAMMA ANALYSIS AT ORNL \\ by T. N. Tiegs
}

Eleven batches of coated particles fabricated by GA and irradiated in capsule $\mathrm{HRB}-15 \mathrm{~B}$ were examined at ORNL with the IMGA system, as shown in Table 5-5. An additional 11 batches of coated particles from HRB-15B were submitted by GA for analysis with the PGA system at ORNL (see Table 5-7). As standard practice, prior to PGA measurement, the particles were gammaanalyzed with the IMGA system to measure burnup so that the theoretical inventories of fission gases in the individual particles could be calculated. Ony small numbers of particles were examined, compared to the total irradiated.

Measurements of the gamma-ray spectrum from irradiated fuel particles has been shown to be useful in determining the performance and fission product retention characteristics of the particles (Refs. $\mathrm{C}-1$ through $\mathrm{C}-3$ ). This is accomplished by taking the ratio of volatile to stable fission products (e.g., Cs-137/Zr-95). The ratios can then be compared to calculated ratios and an assessment made of the performance of the particle batch relative to fission product retention.

The activity ratios of particular interest are Cs $-137 / \mathrm{Zr}-95$ and $\mathrm{Ag}-110 \mathrm{~m} / \mathrm{Zr}-95$. The $\mathrm{Cs}-137 / \mathrm{Zr}-95$ ratio is a good indicator of the SiC coating integrity and has been useful in determining the impact of SiC-fission product interactions during irradiation and out-of-pile heating tests. The $\mathrm{Ag}-110 \mathrm{~m} / \mathrm{Zr}-95$ ratio is of interest because of the influence of silver release on activity in the primary circuit and the attendant implications to the maintenance philosophy of the reactor. The yield of fission product silver from Pu-239 fissioning is considerably higher than from U-235 fissioning, which causes silver retention to be much more of an issue with the current reference LEU fuel cycle than it was in the past with an 
HEU cycle. Silver release has been observed from particles which have successfully retained cesium.

Table C-1 summarizes the results on the $\mathrm{Cs}-137 / \mathrm{Zr}-95$ and $\mathrm{Ag}-110 \mathrm{~m} / \mathrm{Zr}-95$ ratios. The $\mathrm{Ag}-110 \mathrm{~m} / \mathrm{Zr}-95$ ratios were not obtained for the $\mathrm{ThO}_{2}$ particles. Due to the low $\mathrm{Ag}-110 \mathrm{~m}$ production in thorium fuels, it was not readily detected.

The Cs $-137 / \mathrm{Zr}-95$ ratios for all of the particle batches examined indicated that no Cs-137 release had occurred. The reason for the observed ratios being $\sim 10 \%$ higher than the calculated ratios is unknown, although, as will be shown later, the discrepancy is believed to arise in the calculation of the $\mathrm{Zr}-95$ inventory in the particles. The discrepancy was rather consistent among the different particle batches. In previous irradiation tests, the calculated and observed ratios have had very good agreement (Refs. C-3 through $\mathrm{C}-6$ ).

While no Cs-137 release had apparent1y occurred, the $\mathrm{Ag}-110 \mathrm{~m} / \mathrm{Zr}-95$ ratio indicated that the particle batches exhibited varying degrees of $\mathrm{Ag}-110 \mathrm{~m}$ release. The highest releases were on the order of $16 \%$ of the tota 1 inventory according to the $\mathrm{Ag}-110 \mathrm{~m} / \mathrm{Zr}-95$ ratio.

Fission product $\mathrm{Ag}-110 \mathrm{~m}$ is difficult to measure directly by gammaanalysis in irradiated particles and, thus, required tedious examination procedures. The difficulties arise, because $\mathrm{Ag}-110 \mathrm{~m}$, while a good gamma source by itself, is in low enough concentration in irradiated particles compared to other gamma-emitting fission products that detection is difficult. Counting times for each individual particle were from 500 to $1000 \mathrm{~s}$ detector live-time (actual times were $20 \%$ to $40 \%$ higher depending on detector dead-time). Counting errors on the $\mathrm{Ag}-110 \mathrm{~m}$ gamma peak at $884 \mathrm{keV}$ were on the order of $8 \%$.

Fission product $\mathrm{Ru}-106$ can also be used in place of $\mathrm{Zr}-95$ in determining volatile fission product release. When the measured fission product 
inventories were compared with calculated inventories using different cross section sets, some interesting observations were made. (Three cross section sets have been considered in this analysis, as detailed later. Table C-2 compares the observed versus the calculated fission product inventories for position $\mathrm{HRB}-15 \mathrm{~B}-116$. The trend is similar in all other positions. The Cs137 and $\mathrm{Ru}-106$ inventories are calculated too high with the ORNL cross sections and too low with the GA cross sections, with the observed inventories approximately half way between the two. On the other hand, both sets of cross sections overpredicted the $\mathrm{Zr}-95$ inventory observed in the particles. This is why the measured $\mathrm{Cs}-137 / \mathrm{Zr}-95$ ratios were al1 $\sim 10 \%$ above the calculated ratios. For this purpose, the $\mathrm{Cs}-137 / \mathrm{Ru}-106$ and $\mathrm{Ag}-110 \mathrm{~m} / \mathrm{Ru}-106$ ratios may have more quantitative significance.

The production of $\mathrm{Ru}-106$ is similar to $\mathrm{Ag}-110 \mathrm{~m}$, in that much greater yields are associated with plutonium fissions. Thus, the $\mathrm{Cs}-137 / \mathrm{Ru}-106$ ratios get smaller with increasing plutonium fissions. Compare the Cs137/Ru-106 ratios between the three cross section sets shown in Table C-3. (ORNL No. 1 set will have the highest number of plutonium fissions.) Now, when the $\mathrm{Ag}-110 \mathrm{~m} / \mathrm{Ru}-106$ ratios are calculated where both inventories get larger with increasing number of plutonium fissions, the ratios do not significantly change from one cross section set to another (also shown in Table $\mathrm{C}-3)$.

Table $\mathrm{C}-1$ also tabulates the $\mathrm{Cs}-137 / \mathrm{Ru}-106$ and $\mathrm{Ag}-110 \mathrm{~m} / \mathrm{Ru}-106$ ratios. As shown, the observed $\mathrm{Cs}-137 / \mathrm{Ru}-106$ ratios are much closer to calculated values than the $\mathrm{Cs}-137 / \mathrm{Zr}-95$ ratios. Although some of the values are below $100 \%$, no Cs -137 release can be concluded. This is because ratios are very neutron-flux dependent, and $\sim 5 \%$ error in the theoretical calculations would not be unexpected.

The $\mathrm{Ag}-110 \mathrm{~m} / \mathrm{Ru}-106$ ratio, on the other hand, indicates that releases of $\mathrm{Ag}-110 \mathrm{~m}$ could be as high as $32 \%$ from some particle batches. Further detailed analyses will have to be performed to improve the accuracy of the calculated ratios. 
Recently, some questions as to the correct heavy-metal fission and neutron capture cross sections for the RB-facility in HFIR have been brought to light. Table $\mathrm{C}-3$ compares the cross sections. Reference $\mathrm{C}-7$ discusses the origin of the ORNL cross sections. The calculated ratios used in the comparisons with the measured $\mathrm{Cs}-137 / \mathrm{Zr}-95$ and $\mathrm{Ag}-110 \mathrm{~m} / \mathrm{Zr}-95$ ratios just shown used the ORNL No. 2 cross sections from Table C-4. As will be shown later, those cross sections predict activity ratios closer to the observed ratio than any others.

Table C -5 compares the $\mathrm{Cs}-137 / \mathrm{Zr}-95$ and $\mathrm{Ag}-110 \mathrm{~m} / \mathrm{Zr}-95$ ratios derived using the different cross sections. As shown, the Cs-137/Zr-95 ratio does not change significantly, whereas the $\mathrm{Ag}-110 \mathrm{~m} / \mathrm{Zr}-95$ ratio does. Those observations have two related reasons:

1. The U-238 capture cross section changes significantly between the different sets, with the GA set being the lowest. Consequently, that set predicts the lowest amount of plutonium production and fissioning .

2. The fission product yields between uranium and plutonium are only significant1y different for $\mathrm{Ag}-110$ production.

Table C-6 compares the fission yields for the various fissile isotopes (Ref. $\mathrm{C}-8$ ). So while the ORNL cross sections predict higher plutonium fissioning, the calculated theoretical ratios change very little for the $\mathrm{Cs}-137 / \mathrm{Zr}-95$ ratio but drastically for the $\mathrm{Ag}-110 \mathrm{~m} / \mathrm{Zr}-95$ ratio.

From all of the ratio comparisons made, no Cs -137 release is believed to have occurred from the particle batches examined with the IMGA system at ORNL. However, Ag-110m release from the particles apparently occurred, but because of the uncertainties in the calculated ratios, no definitive quantitative release values are concluded. 
The overall errors ( $1 \sigma)$ attributed to the IMGA results are as follows:

$\begin{array}{lr} & \% \\ \mathrm{Cs}-137 / \mathrm{Ru}-106 \text { (fissile particles) } & 7.1-14.2 \\ \mathrm{Cs}-137 / \mathrm{Ru}-106 \text { (fertile particles) } & 8.7-15.0 \\ \mathrm{Ag}-110 \mathrm{~m} / \mathrm{Ru}-106 & 10.3-16.0\end{array}$

These were calculated based on the counting statistics and the errors attributable to the calculated fission product inventories. The counting errors are $<0.6 \%$ ( $512 \mathrm{keV}$ ) and $<0.8 \%$ ( $622 \mathrm{kev}$ ) for $\mathrm{Ru}-106$ on fissile particles; $5.0 \%$ ( $512 \mathrm{keV}$ ) for Ru-106 on fertile particles; $<0.6 \%$ (662 keV) for Cs $-137 ; 5.0 \%$ to $7.5 \%(884 \mathrm{keV})$ for $\mathrm{Ag}-110 \mathrm{~m}$ on fissile particles. The uncertainty in the calculated fission product inventories is believed to range from $5 \%$ to $10 \%$, based on uncertainties in neutron fluxes, cross sections, fission yields, decay constants, and irradiation history. These errors were combined using the propagation of errors formula to arrive at the overall errors given above.

REFERENCES

C-1. Kania, M. J., et al., "Irradiation Performance of HTGR Fertile Fuel in HFIR Target Capsules HT-12 Through HT-15: Part 1," Oak Ridge National Laboratory Report ORNL/TM-5305, February 1977.

C-2. Long, E. L., et a1., "Performance of HTGR Fertile Particles Irradiated in HFIR Capsule HT-32," Oak Ridge National Laboratory Report ORNL/TM-7035, Apri1 1980.

C-3. Tiegs, T. N., "Analysis of $\mathrm{ThO}_{2}$ Particle Irradiation Behavior by Gamma Spectrometry," Trans. Am. Nuc1. Soc. 33, 306 (1979).

C-4. Brown, P. E., and R. L. Faircloth, "Metal Fission Product Behavior in HTR UO 2 -Coated Particle Fuel," J. Nucl. Mater. 59, 29-41 (1976).

C-5. Tiegs, T. N., "Irradiation Performance of HTGR Fuel in HFIR Capsule HRB-13," Oak Ridge National Laboratory Report, to be published. 
C-6. Tiegs, T. N., "Capsule HT-34," in "HTGR Base-Technology Program Annual Progress Report, December 31, 1977," Oak Ridge Nationa1 Laboratory Report ORNL-5643, Ju1y 1980, pp. 70-81.

C-7. Thomas, W. E., et al., "HTGR Experiment HRB-15B: Particle Loading and Irradiation in the High Flux Isotope Reactor," Oak Ridge National Laboratory Report ORNL/TM-5643, July 1980.

C-8. Meek, M. E., and B. F. Rider, "Compilation of Fission Product Yields," General Electric Report NEDO-12154-2, Vallecitos Nuclear Center, 1977. 
TABLE $\quad \mathrm{C}-1$

SUMMARY OF Cs-137/Zr-95, Ag-110m/Zr-95, Cs-137/Ru-106, AND Ag-110m/Ru-106 OBSERVED/CALCULATED RATIOS(a) FOR HTGR FUEL PARTICLES IRRADIATED IN CAPSULE HRB-15B

\begin{tabular}{|c|c|c|c|c|}
\hline \multirow{2}{*}{$\begin{array}{l}\text { Particle Batch } \\
\text { Tray Location }\end{array}$} & \multicolumn{4}{|c|}{ (Observed Ratio/Ca1culated Ratio) × 100} \\
\hline & $\mathrm{Cs}-137 / \mathrm{Zr}-95$ & $\mathrm{Cs}-137 / \mathrm{Ru}-106$ & $\mathrm{Ag}-110 \mathrm{~m} / \mathrm{Zr}-95$ & $\mathrm{Ag}-110 \mathrm{~m} / \mathrm{Ru}-106$ \\
\hline 12 & 107.9 & 92.2 & 94.0 & 71.7 \\
\hline 18 & 112.6 & 106.4 & 88.5 & 76.1 \\
\hline 50 & 102.2 & 98.3 & 109.3 & 77.9 \\
\hline $67(b)$ & 111.7 & -- & -- & -- \\
\hline $71(b)$ & 104.7 & -- & -- & -- \\
\hline $77(b)$ & 109.2 & -- & -- & -- \\
\hline 80 & 108.6 & 100.2 & 83.3 & 73.9 \\
\hline 84 & 111.1 & 103.0 & 83.8 & 70.7 \\
\hline 90 & 112.3 & 103.3 & 85.9 & 72.2 \\
\hline 92 & 105.7 & 101.2 & 83.7 & 71.1 \\
\hline 98 & 111.7 & 102.1 & 84.8 & 70.9 \\
\hline 104 & 112.3 & 95.6 & 84.4 & 67.9 \\
\hline 114 & 100.1 & 98.5 & 83.8 & 76.6 \\
\hline 116 & 110.7 & 104.3 & 83.7 & 73.1 \\
\hline 118 & 110.9 & 100.8 & 85.1 & 71.7 \\
\hline 124 & 111.2 & 100.6 & 85.1 & 70.3 \\
\hline 138 & 106.5 & 95.0 & 92.2 & 76.2 \\
\hline 148 & 110.0 & 99.5 & 85.0 & 70.8 \\
\hline 150 & 111.7 & 100.0 & 87.2 & 72.8 \\
\hline 156 & 107.8 & 96.3 & 83.4 & 68.4 \\
\hline 168 & 112.3 & 97.3 & 99.5 & 77.7 \\
\hline $181(b)$ & 110.8 & -- & -- & -- \\
\hline
\end{tabular}

(a) A11 ratios are of disintegrations per second at end of irradiation.

(b) Only Cs-137/ $\mathrm{Zr}-95$ ratios were obtained on $\mathrm{ThO}_{2}$ batches. 
TABLE $\quad \mathrm{C}-2$

COMPARISON OF OBSERVED AND CALCULATED FISSION PRODUCT INVENTORIES FOR FUEL PARTICLES IRRADIATED IN POSITION HRB-15B-116

\begin{tabular}{l|c|c|c}
\hline \multirow{2}{*}{} & \multicolumn{3}{|c}{$\begin{array}{c}\text { Fission Product Contents Per } \\
\text { Particle (moles) }\end{array}$} \\
\cline { 2 - 4 } & $\mathrm{Ru}-106$ & $\mathrm{Zr}-95$ & $\mathrm{Cs}-137$ \\
\hline Observed(a) & $4.222 \mathrm{E}-9$ & $3.629 \mathrm{E}-9$ & $1.487 \mathrm{E}-9$ \\
Calculated (b) & $4.636 \mathrm{E}-9$ & $4.266 \mathrm{E}-9$ & $1.567 \mathrm{E}-9$ \\
Calculated (c) & $3.773 \mathrm{E}-9$ & $3.905 \mathrm{E}-9$ & $1.417 \mathrm{E}-9$ \\
\hline
\end{tabular}

(a) Average of 21 particles.

(b) Calculated with CACA-II code and ORNL No. 2 cross sections; calculations made with ORNL No. 1 cross sections would be higher.

${ }^{(c)}$ Calculated with CACA-II code and GA cross sections. 
TABLE $C-3$

COMPARISON OF CALCULATED Cs-137/Ru-106 AND Ag-110m/Ru-106 RATIOS USING DIFFERENT CROSS SECTIONS

\begin{tabular}{|c|c|c|c|c|c|c|}
\hline \multirow[b]{2}{*}{ Position } & \multicolumn{3}{|c|}{ Calculated Cs-137/Ru-106 Ratios } & \multicolumn{3}{|c|}{ Calculated $\mathrm{Ag}-110 \mathrm{~m} / \mathrm{Ru}-106$ Ratios } \\
\hline & ORNL No. 1 (a) & ORNL No. 2(a) & $\mathrm{GA}(\mathrm{a})$ & ORNL No. 1(a) & ORNL No. 2(a) & $\mathrm{GA}(\mathrm{a})$ \\
\hline 12 & 1. $511 \mathrm{E}-1$ & $1.819 E-1$ & $2.033 E-1$ & $5.939 E-3$ & $5.703 E-3$ & $5.498 E-3$ \\
\hline 18 & $1.281 \mathrm{E}-1$ & 1. $529 \mathrm{E}-1$ & $1.708 \mathrm{E}-1$ & $6.545 E-3$ & $6.335 E-3$ & $6.142 \mathrm{E}-3$ \\
\hline 50 & 1. $271 \mathrm{E}-1$ & $1.443 \mathrm{E}-1$ & $1.648 \mathrm{E}-1$ & $9.697 \mathrm{E}-3$ & $9.443 E-3$ & $9.162 \mathrm{E}-3$ \\
\hline 80 & $9.913 E-2$ & $1.140 \mathrm{E}-1$ & $1.266 E-1$ & $1.097 \mathrm{E}-2$ & $1.070 E-2$ & $1.046 \mathrm{E}-2$ \\
\hline 84 & $9.884 \mathrm{E}-2$ & $1.136 \mathrm{E}-1$ & $1.260 \mathrm{E}-1$ & $1.101 E-2$ & $1.074 E-2$ & $1.050 \mathrm{E}-2$ \\
\hline 90 & $9.855 \mathrm{E}-2$ & $1.132 \mathrm{E}-1$ & $1.256 \mathrm{E}-1$ & $1.104 \mathrm{E}-2$ & 1. $078 E-2$ & $1.054 \mathrm{E}-2$ \\
\hline 92 & $1.184 \mathrm{E}-1$ & 1. $321 E-1$ & $1.506 \mathrm{E}-1$ & $1.091 \mathrm{E}-2$ & $1.065 E-2$ & $1.037 \mathrm{E}-2$ \\
\hline 98 & $9.777 \mathrm{E}-2$ & $1.121 E-1$ & 1. $243 E-1$ & $1.114 \mathrm{E}-2$ & $1.087 \mathrm{E}-2$ & $1.064 \mathrm{E}-2$ \\
\hline 104 & $9.803 E-2$ & $1.124 \mathrm{E}-1$ & $1 \cdot 247 \mathrm{E}-1$ & $1.113 \mathrm{E}-2$ & 1. $086 \mathrm{E}-2$ & 1. $062 \mathrm{E}-2$ \\
\hline 114 & 1. $188 \mathrm{E}-1$ & 1. $325 \mathrm{E}-1$ & 1. $512 \mathrm{E}-1$ & $1.088 \mathrm{E}-2$ & $1.062 \mathrm{E}-2$ & $1.034 \mathrm{E}-2$ \\
\hline 116 & $9.904 E-2$ & $1.138 \mathrm{E}-1$ & $1.264 \mathrm{E}-1$ & $1.100 \mathrm{E}-2$ & $1.073 E-2$ & $1.049 \mathrm{E}-2$ \\
\hline 118 & 1. $017 \mathrm{E}-1$ & $1.173 E-1$ & $1.306 \mathrm{E}-1$ & $1.077 \mathrm{E}-2$ & $1.050 \mathrm{E}-2$ & $1.025 E-2$ \\
\hline 124 & $1.020 \mathrm{E}-1$ & $1.179 \mathrm{E}-1$ & $1.312 \mathrm{E}-1$ & $1.060 \mathrm{E}-2$ & $1.033 \mathrm{E}-2$ & $1.010 \mathrm{E}-2$ \\
\hline 138 & $1.079 \mathrm{E}-1$ & $1.257 \mathrm{E}-1$ & 1. $405 \mathrm{E}-1$ & $9.865 \mathrm{E}-3$ & $9.600 \mathrm{E}-3$ & $9.359 E-3$ \\
\hline 148 & 1. $133 \mathrm{E}-1$ & 1. $329 \mathrm{E}-1$ & $1.490 E-1$ & $9.373 E-3$ & $9.111 E-3$ & $8.864 \mathrm{E}-3$ \\
\hline 150 & 1. $106 \mathrm{E}-1$ & 1. $331 \mathrm{E}-1$ & $1.491 \mathrm{E}-1$ & $9.214 E-3$ & $8.958 E-3$ & $8.713 E-3$ \\
\hline 156 & 1. $171 \mathrm{E}-1$ & 1. $381 \mathrm{E}-1$ & 1. $548 \mathrm{E}-1$ & $8.805 \mathrm{E}-3$ & $8.551 E-3$ & $8.311 E-3$ \\
\hline 168 & 1. $295 \mathrm{E}-1$ & $1.542 \mathrm{E}-1$ & $1.732 \mathrm{E}-1$ & $7.608 \mathrm{E}-3$ & $7.358 \mathrm{E}-3$ & $7.132 \mathrm{E}-3$ \\
\hline
\end{tabular}

(a) Cross section sets as identified in Table $\mathrm{C}-4$. 
TABLE $\mathrm{C}-4$

ONE-GROUP MICROSCOPIC CROSS SECTIONS

USED IN CAPSULE HRB-15B BURNUP ANALYSES

\begin{tabular}{l|c|c|c|c|c|c}
\hline & \multicolumn{3}{|c|}{ Capture (barn) } & \multicolumn{3}{c}{ Fission (barn) } \\
\cline { 2 - 7 } Nuc1ide & ORNL No. 1 & ORNL No. 2 & GA & ORNL No. 1 & ORNL No. 2 & GA \\
\hline Th-232 & 3.96 & 2.77 & 3.15 & 0.008 & 0.006 & 0 \\
Pa-233 & 32.2 & 32.2 & 30.2 & - & -- & 0 \\
Pa-234 & 150.0 & 150.0 & 5.0 & 1500.0 & 1500.0 & 50 \\
U-233 & 16.1 & 16.1 & 15.8 & 151.0 & 151.0 & 144 \\
U-234 & 40.1 & 40.1 & 36.5 & -- & -- & 0 \\
U-235 & 27.9 & 27.9 & 24.5 & 144.0 & 144.0 & 123 \\
U-236 & 10.2 & 10.2 & 10.2 & -- & -- & 0 \\
U-237 & 110.0 & 110.0 & 30.0 & -- & -- & 0 \\
U-238 & 8.44 & 5.908 & 4.5 & 0.033 & 0.023 & 0.023 \\
Np-237 & 65.6 & 65.6 & 50.6 & -- & -- & 0 \\
Np-238 & 13.0 & 13.0 & 13.0 & 570.0 & 570.0 & 570 \\
Np-239 & 8.3 & 8.3 & 8.3 & -- & -- & 0 \\
Pu-238 & 130.0 & 130.0 & 130.0 & -- & -- & 0 \\
Pu-239 & 142.0 & 142.0 & 142.0 & 281.0 & 281.0 & 281 \\
$\mathrm{Pu-240}$ & 287.0 & 287.0 & 287.0 & - & -- & 0 \\
$\mathrm{Pu}-241$ & 109.0 & 109.0 & 88 & 329.0 & 329.0 & 350 \\
$\mathrm{Pu-242}$ & 36.5 & 36.5 & 17.3 & -- & -- & 0 \\
\hline & & & & & & 0 \\
\hline
\end{tabular}


TABLE $C-5$

COMPARISON OF CALCULATED Cs-137/Zr-95 AND Ag-110m/Zr-95 RATIOS USING DIFFERENT CROSS SECTIONS

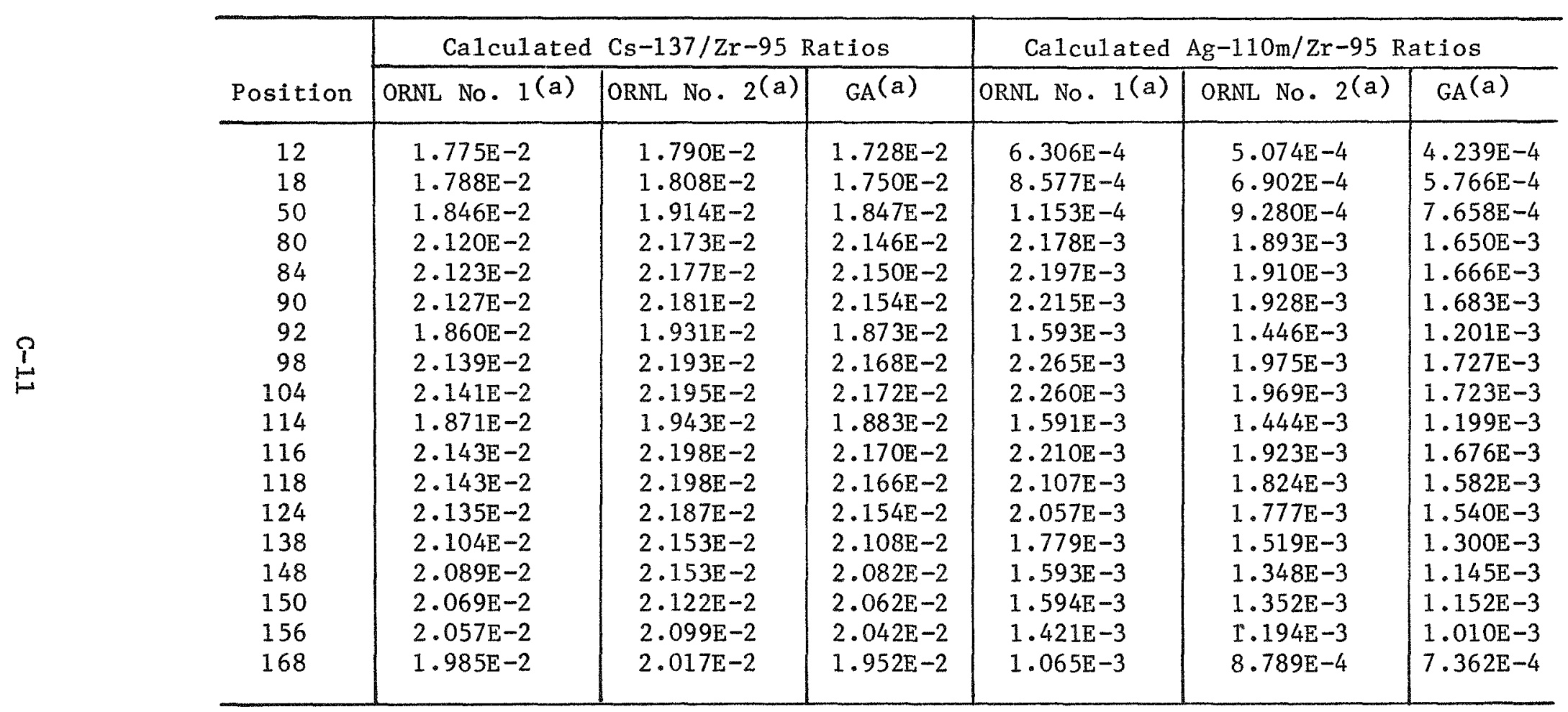

(a) Cross section sets as identified in Table $\mathrm{C}-4$. 
TABLE $C-6$

COMPARISON OF FISSION YIELDS(a)

BETWEEN FISSILE ISOTOPES

\begin{tabular}{l|l|l|l|l}
\hline \multirow{2}{*}{$\begin{array}{l}\text { Fissile } \\
\text { Isotope }\end{array}$} & \multicolumn{4}{|c}{$\begin{array}{c}\text { Fission Yields } \\
(\%)\end{array}$} \\
\cline { 2 - 5 } & $\mathrm{Ru}-106$ & $\mathrm{Ag}-109$ & $\mathrm{Zr}-95$ & $\mathrm{Cs}-137$ \\
\hline $\mathrm{U}-233$ & 0.259 & 0.045 & 6.192 & 6.790 \\
$\mathrm{U}-235$ & 0.400 & 0.033 & 6.497 & 6.227 \\
$\mathrm{Pu}-239$ & 4.309 & 1.654 & 4.890 & 6.633 \\
$\mathrm{Pu}-241$ & 6.182 & 2.249 & 4.089 & 6.854 \\
\hline
\end{tabular}

(a)

Thermal fission yields from Ref. C-8. 


\section{APPENDIX D \\ UNCERTAINTY ANALYSIS ON TRAY GAMMA-SCAN RESULTS}

Other than statistical counting errors, the accuracy in determining the full energy peak efficiency is within a relative standard deviation of $5 \%$. This error was derived by propagating the overall uncertainty of the certified radioactivity standard source and the errors introduced by using an aliquot thereof to prepare the working standard for calibration.

The statistical counting errors are determined during spectral analysis, and these errors are shown in the computer output under the heading SIGMA \%. The statistical counting error, the calibration error, and any other error, such as chemistry errors, must be included in arriving at the total error. The GA Analytical Chemistry Department has assigned a $1 \%$ error for each time diluting, weighing, and pipeting operations are performed. For example, if a sample was assigned that needed to be weighed, diluted, and pipetted and that had a statistical counting error of $1.81 \%$, the overall error would be

$$
\sigma=\sqrt{(5)^{2}+(1.81)^{2}+(1)^{2}+(1)^{2}+(1)^{2}}=5.6 \% \quad .
$$

Generally, the chemistry errors do not significantly change the overal1 error. In this example, the chemistry errors increased the error from $5.3 \%$ to $5.6 \%$.

Originally, when the HRB-15 trays were counted, the interest was qualitative rather than quantitative, so that geometry errors were not considered necessary. However, when quantitative values were to be considered, determining the error in geometry was necessary. (The standard geometries are $2 / 5$ and 2 dram.) To quantify the original spectral data, the GA Analytical Chemistry Department determined correction factors for each shelf 
height and detector used to acquire these data. Based on these correction factors, the maximum geometry error was for HRB-15B tray No. 166, which was high by $14 \%$.

All HRB-15B tray shelf-height geometry errors are shown below:

\begin{tabular}{|c|c|c|}
\hline Tray No. & Shelf Height & $\begin{array}{c}\text { Geometry } \\
\text { Error* }\end{array}$ \\
\hline 166 & 20 & 14.0 \\
\hline 34 & 30 & 11.2 \\
\hline $70,96,67,71,68,90$ & 40 & 10.4 \\
\hline $158,81,67,156,97$ & 50 & $8 \cdot 3$ \\
\hline
\end{tabular}

The error introduced in determining these geometry/detector corrections is $2 \%$ and should be included when determining each overall error.

All trays were decayed to the end of irradiation, January 4, 1979.

The overall uncertainty for the tray gamma-scan results were determined using the following formula:

$$
\sigma_{\text {overal1 }}=\sqrt{\left(\sigma_{\text {measured }}\right)^{2}+\left(\sigma_{\text {calculated }}\right)^{2}}
$$

where $\sigma_{\text {calculated }}=$ uncertainties associated with calculated fission product inventories ( $i . e$. , uncertainties in neutron fluxes, cross sections, fission yields, decay constants, and irradiation history. They are believed to range from $5 \%$ to $10 \%$ ).

$$
\sigma_{\text {measured }}=\sqrt{x^{2}+y^{2}+z^{2}}
$$

\footnotetext{
${ }^{*} \mathrm{All}$ errors are on the high side (i.e., positive division).
} 
where $x=1 \sigma$ accuracy in determining the full energy peak efficiency (i.e. $5 \%$ ),

$y=$ average shelf height geometry errors (i.e., for HRB-15B tray gamma-scans, it was $9.95 \%$ ),

$z$ = average $1 \sigma$ counting error for each nuclide (i.e., for HRB-15B tray gamma-scans, it was $\mathrm{Cs}-137=4.6 \%$ and $\mathrm{Ag}-110 \mathrm{~m}=17.8 \%)$.

Thus,

$$
\begin{aligned}
& \sigma_{\text {measurement }}=\sqrt{5^{2}+9.95^{2}+4.6^{2}}=12.0 \% \text { for } \mathrm{Cs}-137, \\
& \sigma_{\text {measurement }}=\sqrt{5^{2}+9.95^{2}+17.8^{2}}=21.0 \% \text { for } \mathrm{Ag}-110 \mathrm{~m}, \\
& \sigma_{\text {overall for }} \mathrm{Cs}-137=\sqrt{12^{2}+5^{2} \text { or } 10^{2}}=13 \% \text { to } 15.6 \% \text {, } \\
& \sigma_{\text {overall for }} \mathrm{Ag}-110 \mathrm{~m}=\sqrt{21^{2}+5^{2} \text { or } 10^{2}}=21.6 \% \text { to } 23.3 \% \text {. }
\end{aligned}
$$




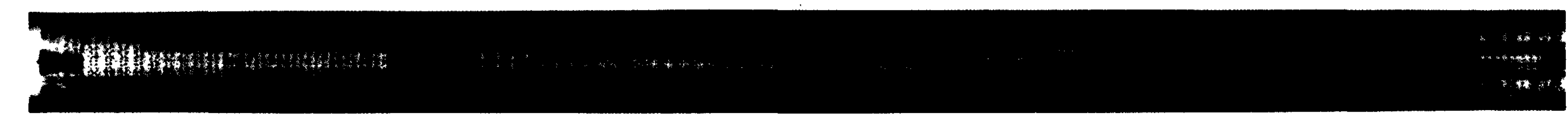

Fig. 2-4. Preirradiation $x$-radiograph Preirradiation $x$-radiograph
of HRB-1.5B, after encapsul-
ation 


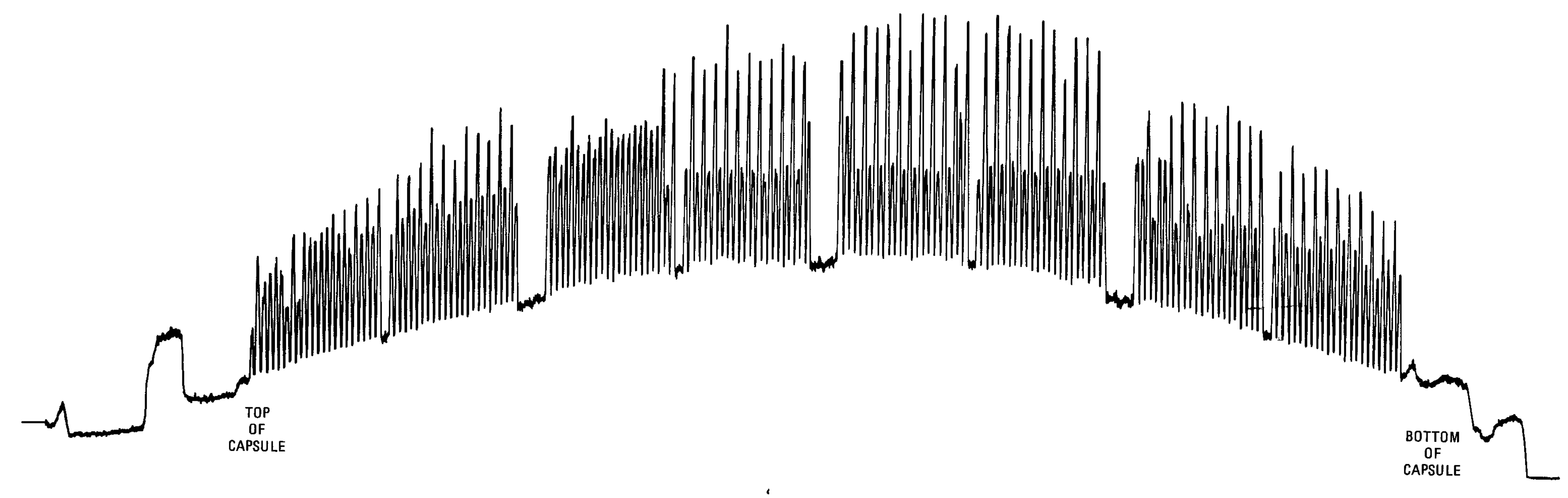

Fig. 5-1. Gamma scan of HRB-15B following removal from HFIR 